\title{
Late Holocene Sedimentation on the Southern Kāpiti Coast.
}

by

Rackley Michael Nolan

A thesis submitted to Victoria University of Wellington in partial fulfilment of requirements for the degree of Master of Science in Geology.

School of Geography, Environment and Earth Science

Victoria University of Wellington 



\section{Frontispiece}

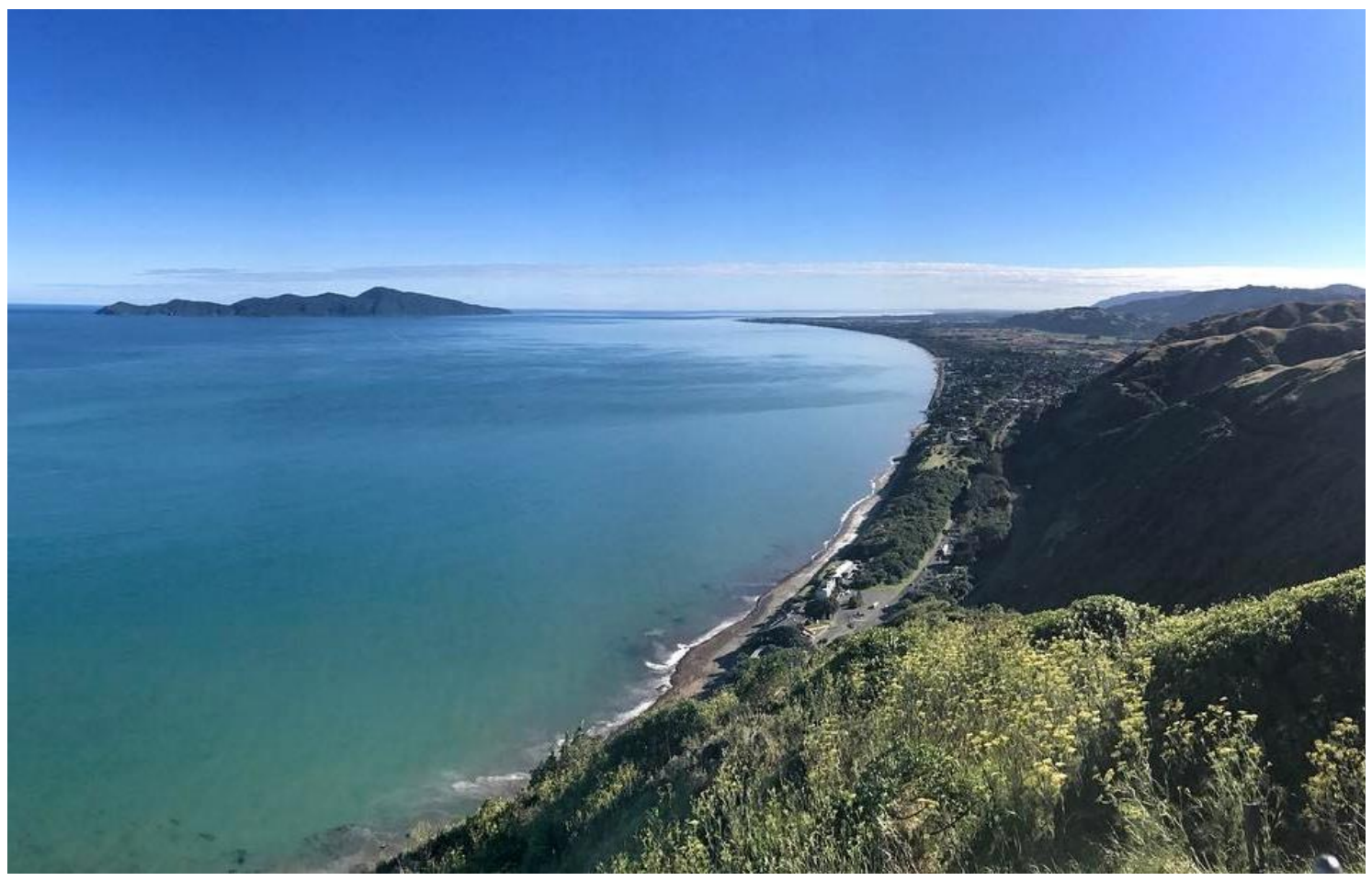

Looking north along the Kāpiti Coast from the lookout on Paekakariki Hill Road, on a fine day. On the right of frame is the escarpment that marks the seaward edge of the Tararua Range, with the southern Kāpiti Coastal Plain between it and the sea. The cuspate foreland at Paraparaumu Beach can be seen extending towards Kāpiti Island on the left. Photo courtesy of Himiona Grace. 


\section{Abstract}

The Kāpiti Coast is a broad low lying coastal plain on the western coast of New Zealand's North Island. The coastal plain has formed over the last 6500 years through rapid progradation of coastal sediment, developing a distinct cuspate foreland. With numerous coastal communities across the low coastal plain, recent coastal erosion of the southern coastal plain combined with forecast sea level rise has drawn attention to coastal hazards. However, understanding these hazards has been hampered by a lack of information on the Holocene tectonic and sedimentary development of the coastal plain.

This study focuses on the southern portion of the Kāpiti Coast using a geological approach to document coastal outcrops and drillcores. Using detailed sedimentological analysis including description, grainsize, composition and shape, in addition to observation of the modern environment, a detailed facies scheme and depositional model for the southern Kāpiti Coast are produced.

Combining the interpreted depositional environments and age control provided by C14, OSL and well-dated pumice deposition, progressive coastal progradation and a transition from marine to terrestrial environments is reconstructed for the southern Kāpiti Coast. Records from this study reveal rapid sedimentation, at rates of up to $12.6 \mathrm{~m} / 1000$ years within this southern limb, slowing dramatically with coastal retreat beginning within the last 400 years.

Recognising the vertical offset of the beach/dune boundary as a marker of past sea level recorded in the cores and outcrops, a $1 \mathrm{~m}$ uplift is recognised at the southernmost point of the coastal plain. In addition to constraining the penultimate movement of the Ohariu Fault, it contrasts with the tectonic stability of the central part of the coastal plain and subsidence further north. Such insight into vertical base level change across the coastal plain has implications for future coastal hazard identification. 


\section{Table of Contents}

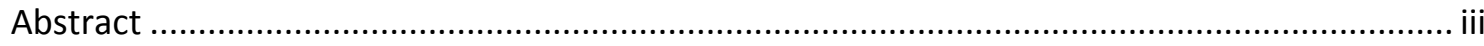

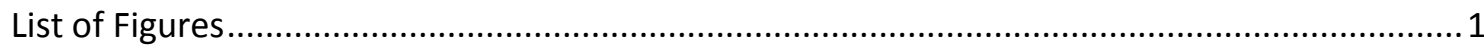

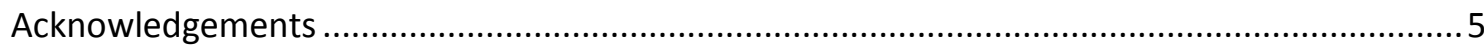

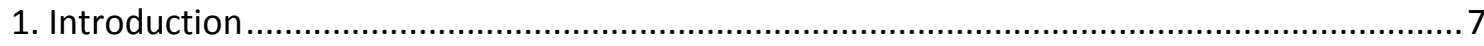

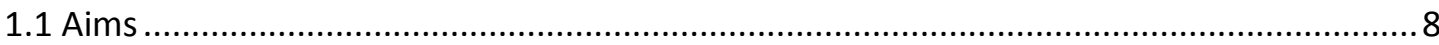

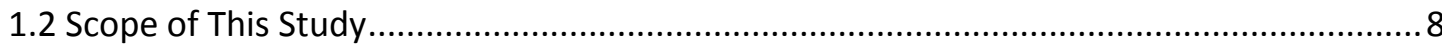

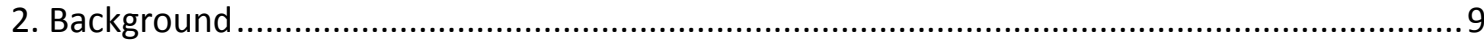

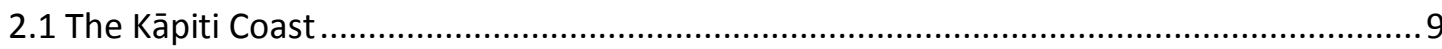

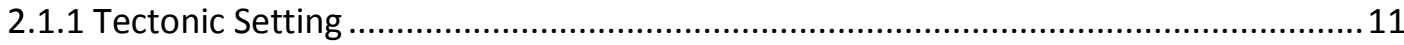

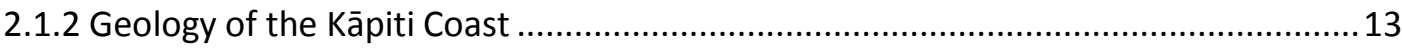

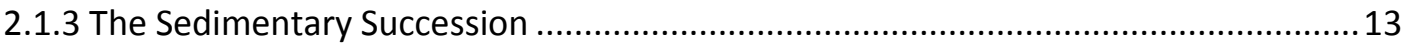

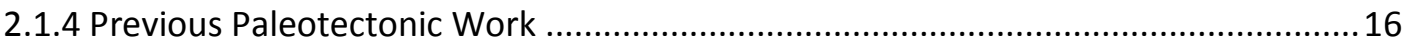

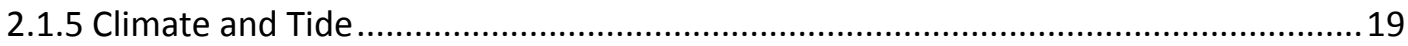

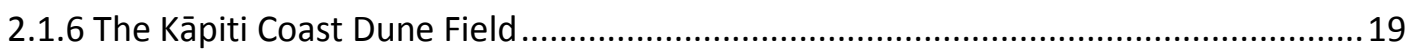

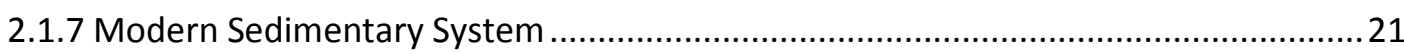

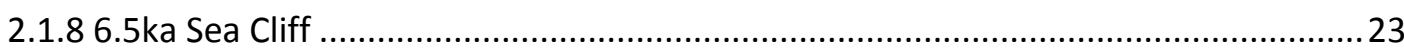

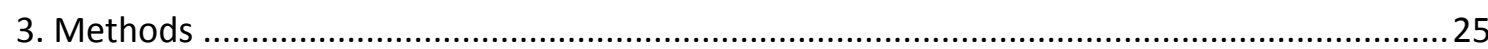

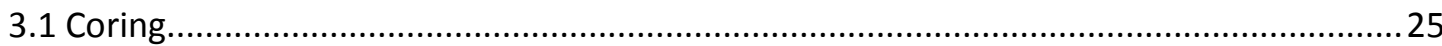

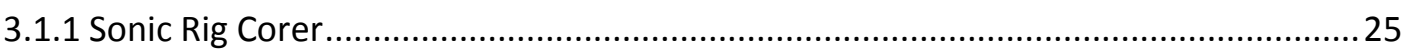

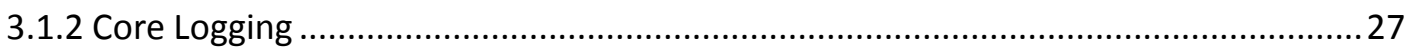

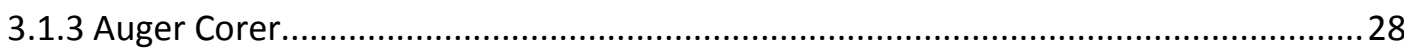

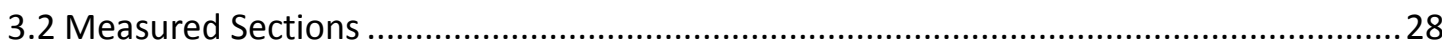

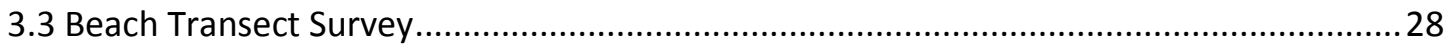

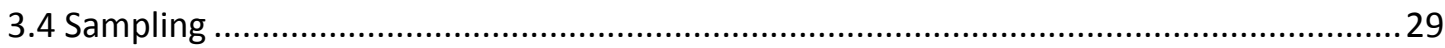

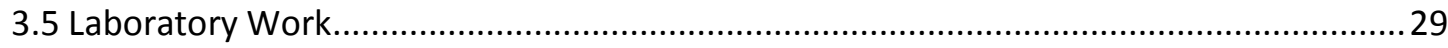

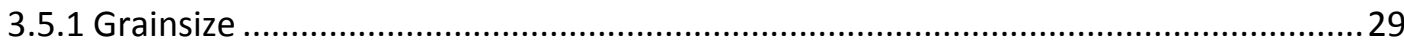

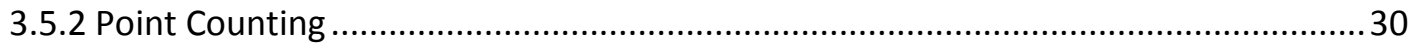

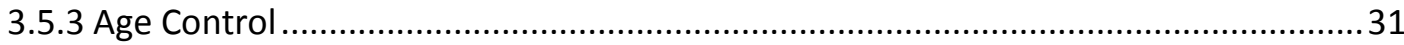

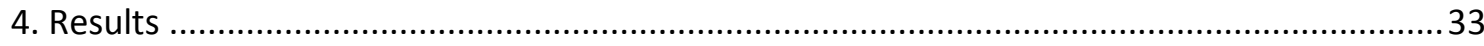

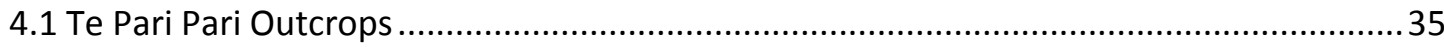

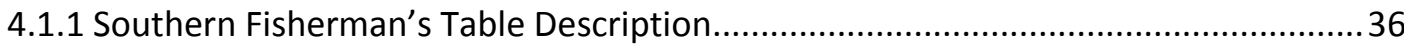

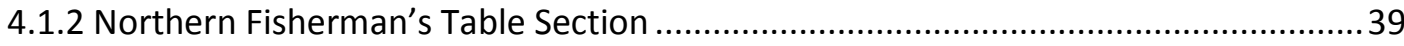

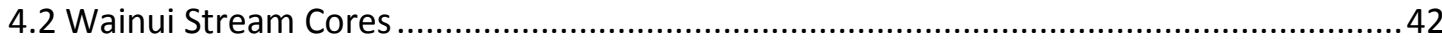

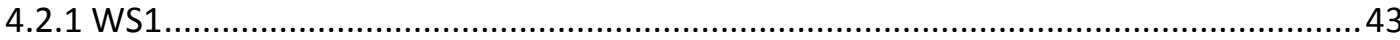

4.2.2 WS3

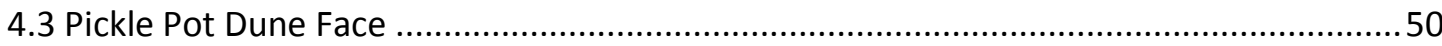




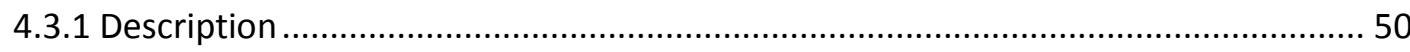

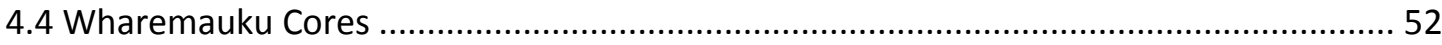

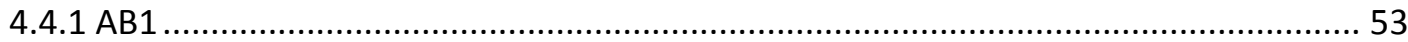

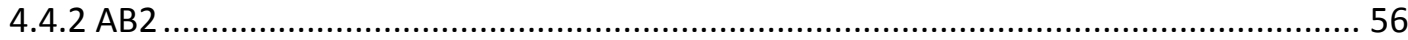

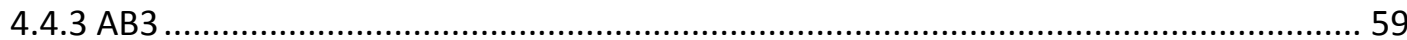

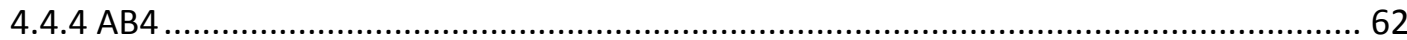

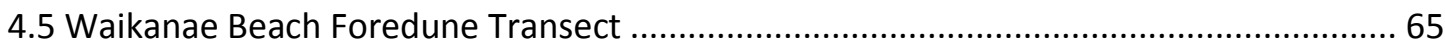

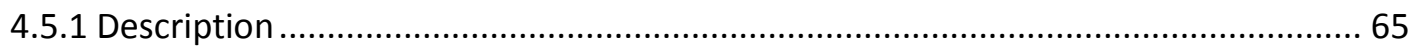

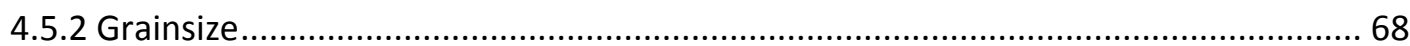

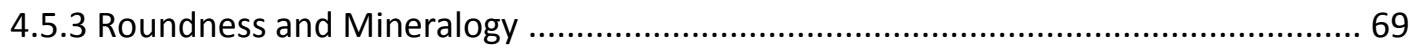

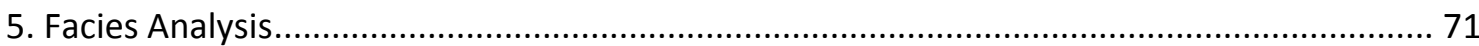

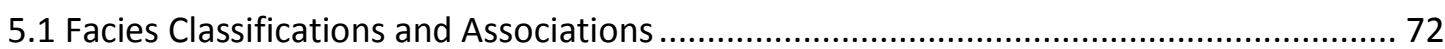

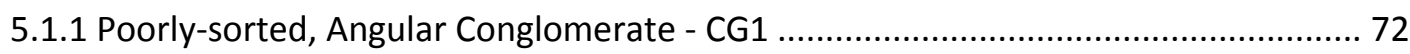

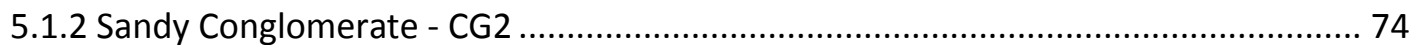

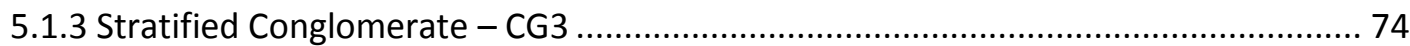

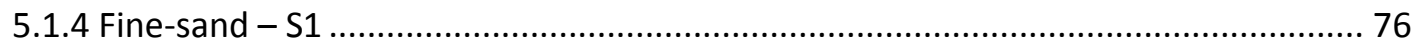

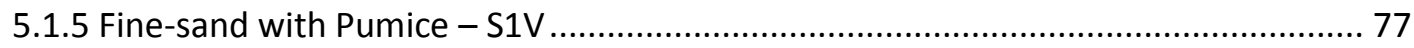

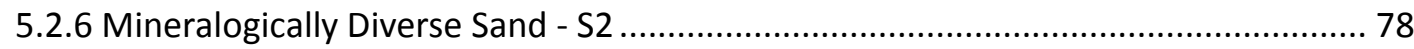

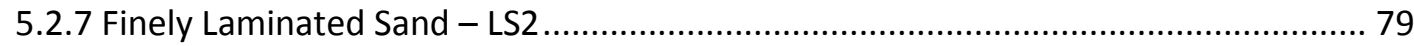

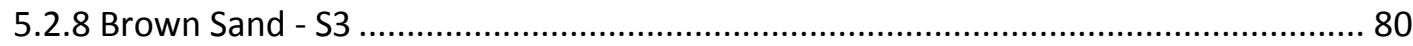

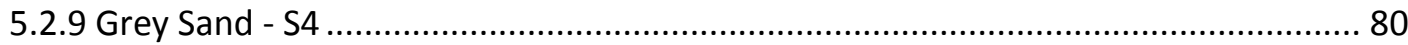

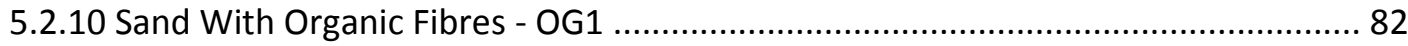

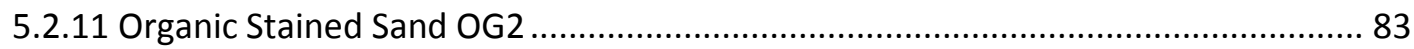

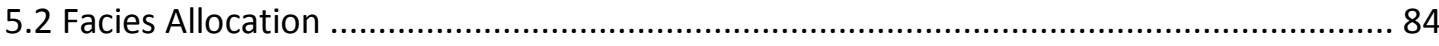

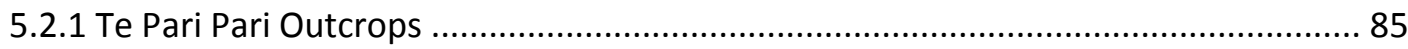

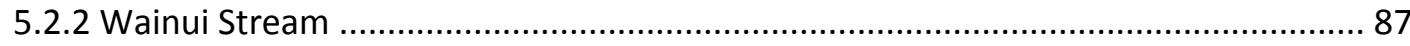

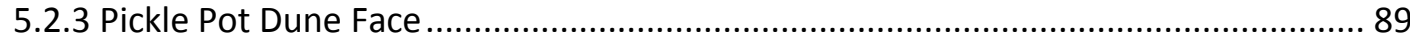

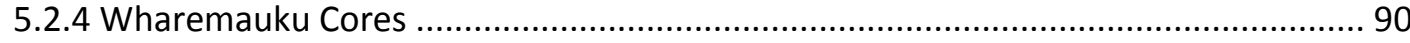

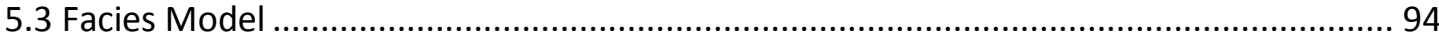

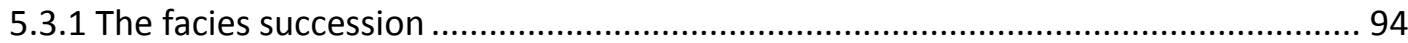

5.3.2 Depositional Model for the Southern Kāpiti Coast ........................................... 96

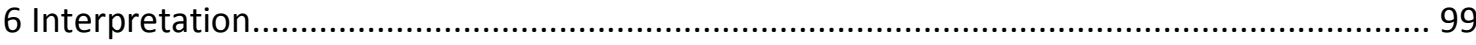

6.1 Te Pari Pari Outcrops ................................................................................. 100

6.1.1 Environmental Interpretations .................................................................. 100

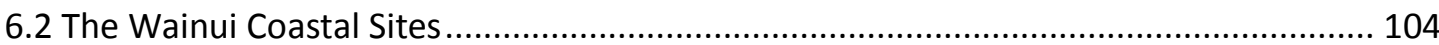

6.2.1 Environmental Interpretations ................................................................. 104

6.2.2 Grainsize Interpretations ..................................................................... 110 
6.3 The Wharemauku Cores ............................................................................. 111

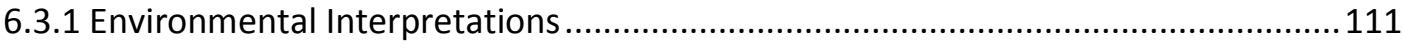

6.3.2 Interpretations of Grainsize and Point Counting ............................................ 114

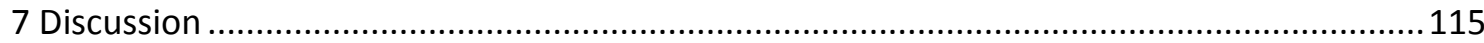

7.1 The Kāpiti Coast's Sediment Supply ............................................................. 115

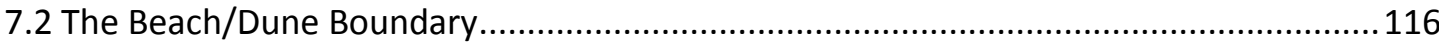

7.3 Facies Identification and Differentiation .......................................................... 118

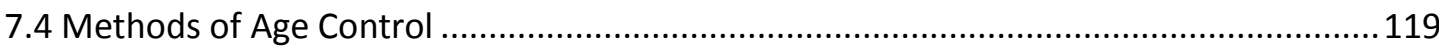

7.5 Late Holocene Evolution of the Southern Kāpiti Coastal Plain................................... 120

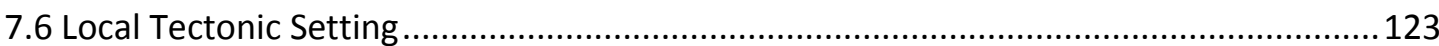

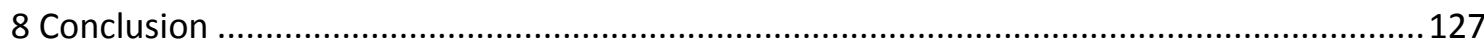

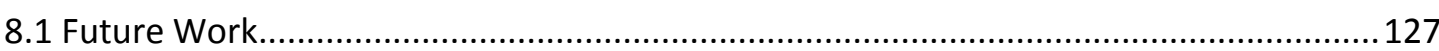

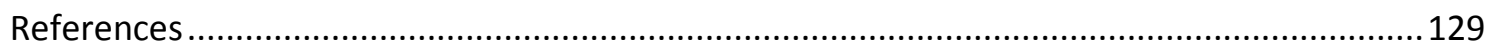

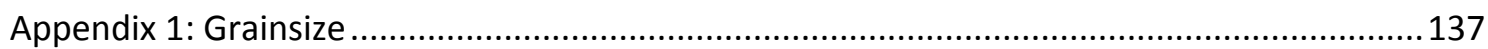

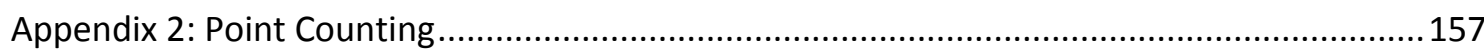

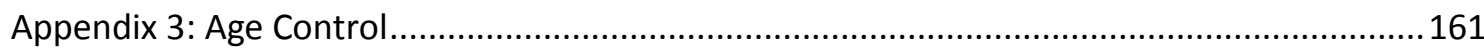

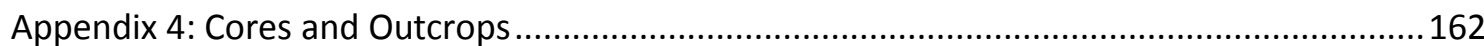




\section{List of Figures}

Figure 2.1: Map of the Kāpiti Coast study area.

Page 9

Figure 2.2: A diagram of the tectonic arrangement beneath the Kāpiti Coast.

Page 11

Figure 2.3: The mapped faults of the southwest South Wanganui Basin.

Page 12

Figure 2.4: Cross section of a typical nearshore environment and sedimentary structures.

Page 16

Figure 2.5: Locations of previous paleotectonic studies throughout the Wellington region.

Page 17

Figure 2.6: Mean grain size for samples collected along a length of Kāpiti Coast shoreline.

Page 22

Figure 2.7: A regional sea level curve for New Zealand during the recent deglaciation period.

Page 24

Figure 3.1: Webster Drilling's track mounted sonic drill rig on location at the WS3 core site.

Page 25

Figure 3.2: Removal of the sample from the drill barrel.

Page 26

Figure 3.3: Splitting the WS3 core.

Page 27

Figure 3.4: Grainsize distribution of three samples of AB1-11.0 to demonstrate reproducibility of the sample splitting method.

Page 30

Figure 4.1: Localities of the study sites across the Kāpiti Coastal Plain.

Page 33

Figure 4.2: A key to the symbols used in the results section.

Page 34

Figure 4.3: Photo of the Te Pari Pari outcrops at the southern portion of the Kāpiti Coastal Plain.

Page 35

Figure 4.4: Annotated photo of the lower portion of the South Fisherman's Table (SFT) section.

Page 36

Figure 4.5: The measured section for the South Fisherman's Table (SFT) outcrop.

Page 37

Figure 4.6: The clasts from the lowest pumaeceous sand in the NFT section.

Page 38

Figure 4.7: Annotated photo of the North Fisherman's Table (NFT) outcrop.

Page 39 
Figure 4.8: The measured section for the North Fisherman's Table (NFT) outcrop.

Page 40

Figure 4.9: Looking southwest across the Wainui Stream mouth, with the locations of the WS1 and WS3 cores shown.

Page 42

Figure 4.10: The $2.2 \mathrm{~m}$ WS1 core log.

Page 44

Figure 4.11: The $29 \mathrm{~m}$ WS3 core log.

Page 46

Figure 4.12: The poorly-sorted conglomerate unit 1 of the WS3 core.

Page 47

Figure 4.13: A sequence of organic material from unit 4 in the WS3 core.

Page 47

Figure 4.14: Graph demonstrating the modal grainsize, sorting (std. dev.) and percent mud for the WS3 core.

Page 49

Figure 4.15: Looking south towards Paekakariki from the Pickle Pot outcrop.

Page 50

Figure 4.16. The measured section for the Pickle Pot outcrop.

Page 51

Figure 4.17: The locations of the Wharemauku cores.

Page 52

Figure 4.18: Core log of the AB1 core taken from Kāpiti Airport.

Page 54

Figure 4.19. Core log of the AB2 core taken from Kāpiti Airport.

Page 58

Figure 4.20: Core log of the AB3 core taken from Kāpiti Airport.

Page 60

Figure 4.21: Core log of the AB4 core taken from Kāpiti Airport.

Page 63

Figure 4.22: Photo of the location for the Waikanae Beach transect.

Page 65

Figure 4.23: Graphic of the Waikanae Beach transect.

Figure page 66, caption page 67

Figure 4.24: Grainsize distribution for all samples in the Waikanae Beach transect.

Page 68

Figure 4.25: Grainsize composition of the Waikanae Beach transect samples.

Page 69

Figure 5.1: A generalised vertical succession of foreshore and nearshore environments and their distinct sedimentary structures.

Page 72 
Figure 5.2: The poorly-sorted CG1 conglomerate.

Figure 5.3: A deposit of gravel on a modern foreshore.

Figure 5.4: Photo of the infilled channel structure within the CG3 facies.

Figure 5.5: The modern interpretation of the CG3 facies.

Figure 5.6: Planar cross laminated beds of fine brown sand in the S1 facies.

Page 76

Figure 5.7: Photo displaying dipping laminations in the S1V facies.

Figure 5.8: The finely laminated bedding in the LS2 facies.

Figure 5.9: The broken juvenile Tanea zelandica from the WS3 core.

Page 81

Figure 5.10: A drifted deposit of wood pieces and other organic fibres below the high tide line on the beach at Paekakariki.

Page 82

Figure 5.11: The interpreted environment of the OG2 facies.

Page 83

Figure 5.12: The facies identified in this study, their features and interpreted environments.

Page 84

Figure 5.13: The facies coding and interpretations for the SFT section.

Figure 5.14: The facies coding and interpretations for the NFT section.

Page 86

Figure 5.15: The facies coding and interpretations for the WS1 core.

Figure 5.16: The facies coding and interpretations for the WS3 core.

Figure 5.17: The facies coding and interpretations for the Pickle Pot outcrop.

Page 89

Figure 5.18: The facies coding and interpretations for the $A B 1$ core.

Figure 5.19: The facies coding and interpretations for the AB2 core.

Figure 5.20: The facies coding and interpretations for the AB3 core. 
Figure 5.21: The facies coding and interpretations for the AB4 core.

Page 93

Figure 5.22: The facies successions for each core and outcrop from this study.

Page 95

Figure 5.23: The vertical succession of the eleven facies in this study and the four environments that they are allocated to.

Page 96

Figure 5.24: A depositional facies model for the southern Kāpiti Coast.

Figure page 97, caption page 98

Figure 6.1: The environmental correlation of the facies succession in the NFT (Left) and SFT (right) of the Te Pari Pari Outcrops.

Page 101

Figure 6.2: This photo displays the landward dipping beds of well-sorted white pumice grains in the S1V facies amongst brown sand at the NFT.

Page 103

Figure 6.3: The foreshore just north of the Wainui stream, looking south towards the escarpment.

Page 106

Figure 6.4: A composite age-depth curve for the WS1 and WS3 cores.

Figure page 107, caption page 108

Figure 6.5: The correlation of environmental interpretations for the Wharemauku cores.

Page 112

Figure 7.1: The modern and paleo shoreline locations of the Kāpiti Coast.

Page 122

Figure 7.2: Constraining the penultimate movement of the Ohariu fault.

Page 124

Figure 7.3: The relative vertical changes in base level experienced throughout the Kāpiti Coast.

Page 125 


\section{Acknowledgements}

First I would like to thank my supervisors Cliff Atkins and Warren Dickinson for their guidance, expertise and opinion that has been invaluable throughout this project, and their enthusiastic undergraduate teaching that first sparked my interest in Geology. The knowledge of B. Alloway, J. Carter, K. Collins, G. Dunbar, B. McFadgen and N. Mulcahy supported important parts of the project, from local expertise to fossil identification and knowledge on geomorphic processes, thank you. J. Carter's help with funding for a radiocarbon date is also greatly valued. Thank you to R. Hughes and my Mum for proofreading and constructive comments. The comments of the two markers are also appreciated.

Thank you to the field companions E. Galbraith, M. Hannah, A. Milner, A. Thomas and to D. Tessler who also helped with photos. The help and expertise of the Victoria University technical staff: S. Bush, J. Chewings and N. Wang, has proven beneficial to many facets of this project. The skills of the staff at the Waikato and GNS radiocarbon facilities who processed samples from this study is greatly appreciated. Thank you to the other members of the John Bradley Library for the morale, laughs and silence, and to the rest of my friends for their encouragement throughout this project. Great appreciation also goes to B. Isaacs for her laughter, unwavering support and late dinners during the final months.

Thanks go to many others for their help in various parts: Webster drilling and Aurecon for help with drilling and cores; B. Bulliff from the GWRC for land access to drill in the QE2 Regional Park; C. Pryor for locating an original GNS sample form; and M. Ryan for OxCal and radiocarbon assistance. Every person listed and so many others have helped in more ways than one, to which I am grateful.

Finally my greatest appreciation to the earliest field companions, my family including my dog. Thank you to my sister for the endless baking through the final weeks and for assistance with the list of figures on the eve of my hand in. The support and motivation from my parents has been irreplaceable throughout my education and to this I am so grateful. I dedicate this to the memory of my Grandmother Lynne, who was unable to see this completed. 


\section{Introduction}

The Kāpiti Coast is a low lying coastal plain of vegetated sand dunes on the west coast of New Zealand. It is positioned between the escarpment of the Tararua Ranges and the edge of the Tasman Sea. The majority of the plain has accreted since the stabilisation of sea level 6.5ka, however some inland portions near Otāki date back to the glacial period or early Holocene. The coastal plain has rapidly accumulated against the bedrock in the area, due to sediment supplied through a southward longshore drift Low lying coastal areas are expected to be the hardest hit by climate change and the related sea level rise. As sea levels continue to rise, development of the Kāpiti Coast continues with housing and infrastructure projects improving the appeal of the area as an outer suburb for Wellington. Attempts by the council to mitigate the effects of future sea level rise on the area, have been met with opposition from residents. A coastal erosion report, commissioned by the council, was used to inform a district plan that enforced restrictions to coastal development. Legal proceedings determined that the report lacked background information and the restrictions were lifted.

Previous studies on the Kāpiti Coast have focused on the dune geomorphology and the modern erosion/accretion sediment budget. The understanding of the Kāpiti Coast's progradation is limited to the Holocene deposition due to a southward longshore drift sediment transport. This has accumulated to form the coastal plain, with welldeveloped dune sequences. The sedimentary succession and the characteristics of other depositional environments for the coast has escaped attention.

Research in this study focuses on the development of the sedimentary succession on the southern portion of the coastal plain through the Holocene. The sedimentary record is studied from cores and outcrops, producing a facies scheme to understand the depositional environments and history.

As the research of this study reveals changes in depositional environments at the study locations, age control is used to determine the rate at which these changes occurred. This study utilises radiocarbon and optically stimulated luminescence dating methods for samples, as well as first occurrence of pumice from well-known eruptions. These dates allow the cores and outcrops to be interpreted in relation to each other, revealing the progradation of the Kāpiti coastal plain at each site through time. 
As a method of informing the paleo records collected in cores and outcrops, a transect of the beach/dune transition at Waikanae Beach was recorded. This transect records the transition between the beach and dune environments in a modern prograding setting, to assist in its identification in the paleo environment. The beach/dune boundary in the sedimentary record is evaluated in this study as a method of identifying vertical base level changes, and paleoseismic events.

While some early studies on the area established some of the basic geological history for the coast, the majority of the following studies have focused on the succession of dune sequences and the sediment supply to the coastline. This study shows the southern Kāpiti Coastal plain has rapidly prograded following the stabilisation of sea level 6.5ka years BP. A decrease in the sediment supply due to the progradation of the cuspate foreland at Paraparaumu slowed the growth in this part of the coast following $4 k a$ years BP. This decline in sediment supply has begun an erosional phase for the southern Kāpiti Coast, beginning within the last 1700 years.

\subsection{Aims}

This study will examine the sedimentary history of the southern Kāpiti Coastal plain for the last 6500 years, since the stabilisation of sea level. This will be achieved through the following objectives:

- Descriptions of outcrops and cores within the coastal plain;

- Analysis of sedimentary and fossil content of the records examined;

- Development of a dedicated facies scheme and depositional model informed by a modern beach/dune transect;

- Correlation of facies and interpretation of environments, in particular identifying the beach/dune boundary as a potential seismic marker;

- Reconstruct a paleogeographic interpretation of the southern Kāpiti Coast's shoreline over the last 6500 years.

\subsection{Scope of This Study}

The cores and outcrops studied in this study are distributed from the cuspate foreland at Paraparaumu Beach, south to the Te Pari Pari cliffs. These are within the currently eroding southern Kāpiti Coast, with locations selected to best represent parts of the sedimentary wedge. The prograding northern Kāpiti Coast is not considered in this study beyond the use of the transect at Waikanae Beach. 


\section{Background}

\subsection{The Kāpiti Coast}

The Kāpiti Coast is a southern segment of the western coast of New Zealand's North Island. The district stretches nearly 40km from the Te Pari Pari cliffs south of Paekakariki, northwards to Otāki (figure 2.1). The coastline is composed of a nearly uninterrupted dissipative sandy beach (Finkl, 2004), featuring a wide surf zone where energy is lost before reaching the shoreline. Kāpiti Island is the only major offshore island for this segment of coast and to the east of the island a cuspate foreland has developed in its wave shadow, giving the coastal plain its greatest width of nearly $4 \mathrm{~km}$. The eastern margin of the Kāpiti Coast is the uplifting Tararua ranges, part of New Zealand's axial range. On the Kāpiti Coast the foothills form an easily distinguishable escarpment, erosion of the ranges has formed gravel deposits against the escarpment of the foothills.

The coastline is dominated by sand but has several river mouths and a small length of intermediate pebble and cobble foreshore south of the Otaki River. Between the coastline and the foothills of the Tararua Range, the dominant geomorphic features are dunes and interdune swampy areas. Streams, rivers and wetlands drain the inland ranges across the gently inclined coastal plain, with urban development covering a large portion of the dune belt.

Several coastal communities, including the town of Paraparaumu, are built on the dune system with many built up areas proximal to the shoreline. Concern around coastal erosion has become a contentious issue, with major uncertainty regarding the tectonic regime and sedimentation processes preventing coastal hazard mitigation planning. For this area of increasing urban density, forecasts of rising sea level demand action on the district's future development. 


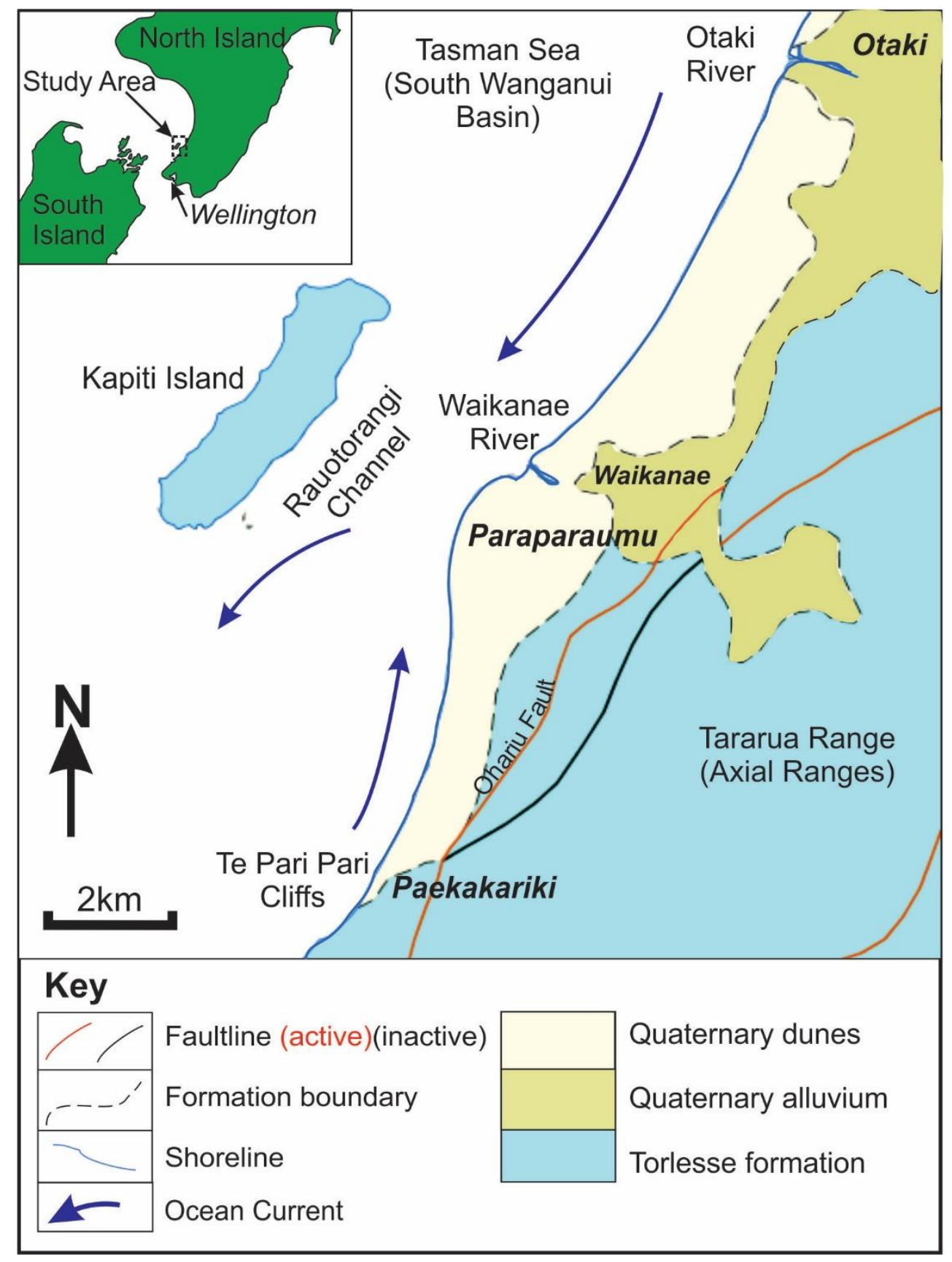

Figure 2.1: Map of the Kāpiti Coast. Regional context of study area, major towns, ocean currents, geology and major faults are shown. Geological units modified from the GNS QMap (Begg et al., 2000), ocean currents reproduced from Gibb (1978a). 


\subsubsection{Tectonic Setting}

Tectonically the Kāpiti Coast is positioned (figure 2.2) above a convergent margin beneath New Zealand, where the Pacific Plate subducts beneath the Australian Plate (Wallace et al., 2004). The location of the Kāpiti Coast between the south-east edge of the subsiding South Wanganui Basin (Anderton, 1981) and the foothills of the uplifting Tararua Ranges (Ewig, 2009), lead to uncertainty of the coastal plains relative motion.

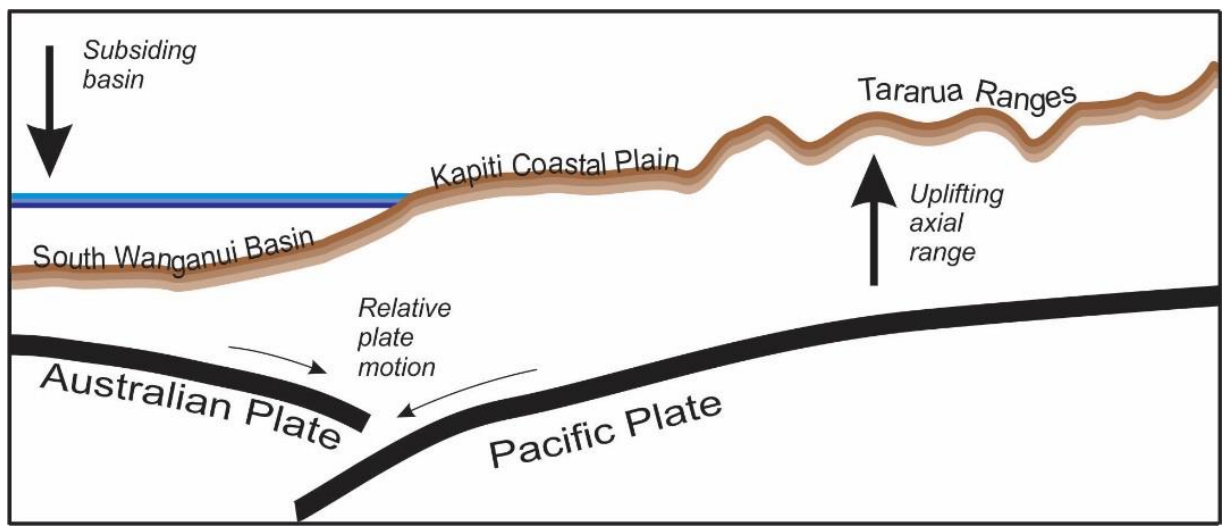

Figure 2.2: A schematic W-E cross section diagram of the tectonic arrangement beneath the Kāpiti Coast (Lamb and Vella, 1987).

Local features of the regional tectonic strain take the form of numerous NNE trending faults (Ewig, 2009) which dissect the region. Many faults mapped throughout the region show a north to south trend (figure 2.3). While the magnitude of movement for many of these fault systems is not known, the most significant, recently active fault is the Ohariu fault (Van Dissen and Heron, 2003). The dextral fault extends from Wellington's South Coast, through Porirua to the Kāpiti Coast (figure 2.1), tracing near the eastern side of the coastal plain. The vertical offset of $40 \mathrm{~m}$ for a $120 \mathrm{ka}$ marine terrace on the South Coast is attributed the uplift of the western side of the Ohariu fault, while vertical displacement on the Kāpiti Coast is typically smaller (Heron et al., 1998). The dissection of the numerous faults in the region is recognised in a large number of fault blocks beneath the west coast of the Wellington area south of the Kāpiti Coast (Suneson, 1993). 


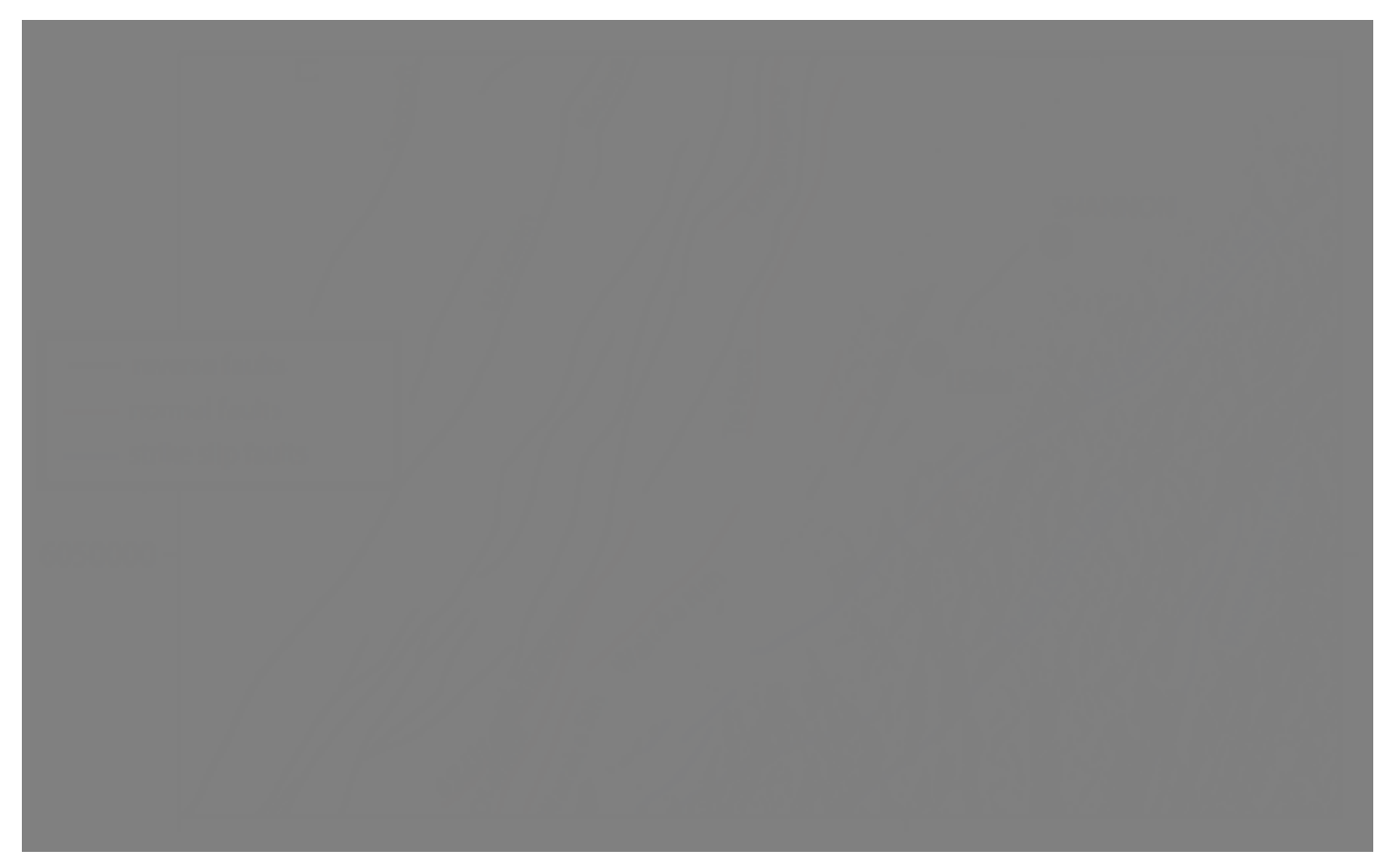

Figure 2.3: The mapped faults and their sense of movement for the southwest corner of the South Wanganui Basin in the vicinity of the Kāpiti Coast (adapted from Ewig 2009). 


\subsubsection{Geology of the Kāpiti Coast}

Against the foothills of the Tararua Range, the Kāpiti Coastal Plain has developed throughout the Holocene as a product of local climate and sediment supply while Kāpiti Island has facilitated the growth of the cuspate foreland at Paraparaumu, which forms the noticeable change in the shape of the coastline. The area shares the common basement of the wider Wellington region with the late Triassic - early Jurassic Torlesse Sandstone Terrane (Adams and Graham, 1996). This Torlesse basement forms Kāpiti Island and the shore platform south of Paekakariki (figure 2.1).

Between the Tararua Ranges and the ocean are Quaternary deposits, consisting of colluvium, alluvium and sequences of dune development. Deposits of colluvium material are located against the foothills of the axial range, the origin of this material alluvium deposits are located proximal to many of the streams and rivers of the coastal plain (Adkin, 1951), notably extending from Otāki south towards Paraparaumu. The dune deposits of the Kāpiti Coast extend from almost the complete length and width of the coastline (figure 2.1). Because Kāpiti Island has shielded this portion of coastline from incident westerly waves, the cuspate foreland has developed with a gentle curve as a result of shoaling swells refracting towards the coastline (Wright, 1988) allowing sediment to deposit in the wave shadow.

\subsubsection{The Sedimentary Succession}

The Kāpiti Coast is a strand plain (McCubbin, 1982) of sediment deposition along a dissipative coastline (Finkl, 2004), leading to a distinctive sedimentary succession which results from the diverse environments that occur across its width. A coastal plain or strand plain is a product of the successive formation of shoreline deposits such as berms and foredunes, which accumulate from continued wave and wind energy depositing sediment (Bristow et al., 2000, Kirby, 2002). In a system with stable sea level and a positive sediment budget, the shoreline will prograde with the repeated formation of these shoreline deposits, extending the shoreline and the strand plain further seaward (Boggs, 2011, Evans, 1979). Low lying coastal plains, such as the Kāpiti Coast, exist on the inner margin of many of the worlds continental shelves (Ying and Xiankun, 1989, Seddon, 1972, Ewing et al., 1950, Chakrabarti, 1995). These form the emergent margin of the continental shelf and their processes such as wave climate and sediment supply directly influence the processes that occur on the continental shelf (Davis, 2012). 
Beneath the sedimentary package of the modern strand plain, lies a transgressive surface, which resulted from sea level rise since the Last Glacial Maximum (Dunbar and Barrett, 2005). It forms as a result of the wave interaction with the exposed shelf as the shoreline moves landward (Evans, 1979). Using a facies model for PliocenePleistocene transgressive-regressive system change for the Wanganui basin, Naish and Kamp (1997) describe the marine transgression as an erosional unconformity overlain by a rapidly fining marine unit. This upward fining unit is a product of the increasing water depth reducing the amount of shear stress from wave energy experienced at the deposition surface (Dunbar and Barrett, 2005).

In the progradation of coastal plains, deposition can occur in the offshore and onshore environments and is not restricted to the shoreline. Windblown and fluvially deposited systems can cause deposition on strand plains a great distance inland from the foredune. This process is visible in the Manawatu area north of Kāpiti, which features long blown out parabolic dunes (Cowie, 1963), a product of long distance sand transport from a dominant wind, these overlie floodplain deposits from the Manawatu River (Clement et al., 2010). Offshore deposition typically occurs due to supply from the shoreline, sediment held in suspension from wave or current activity will be deposited offshore as water returns to the deeper ocean (Aubrey, 1979). Deposition from suspension is a product of wave energy, the coarsest material remains at the shoreline (Kirby, 2002), and the finer material is held suspended in water as it moves beyond the break zone (Brander, 1999). Analysis of the offshore sediments for the Kāpiti Coast demonstrates a pattern of grainsize fining with increased depth and distance from shore (Perrett, 1990), as expected on a wave graded continental shelf (Dunbar and Barrett, 2005).

Previous facies studies have focussed on parts of the coastal plain north of the Kāpiti Coast and the terrestrial environments of its formation (Muckersie and Shepherd, 1995, Cowie, 1963). Moving basinward from the base of the axial ranges that form the landward margin of the study area, the first distinct deposits in the sequence, are those that form the fan deposits (Clement et al., 2010). These fan deposits are formed of Torlesse sandstone sediment originating from the Tararua Ranges and delivered through fluvial and colluvial processes (Adkin, 1951). 
Dune landscapes such as the Kāpiti Coast feature a range of environments that are part of the dune system. The dunes along the Te Horo coast have been the focus of previous studies, as these are some of the most intact shore parallel belts in the area (Hawke and McConchie, 2006, Hawke and McConchie, 2005). Typically the formation of a foredune begins parallel and at the shoreline with the supply of sand from the ocean (Hesp, 1988). As a shoreline progrades through increased deposition, with it the foredune's point of nucleation will move, either forming a new foredune, or causing the existing foredune to thicken. If there has not been sufficient vegetation to prevent erosion of the loose sand, it may continue to advance inland under the dominant wind (Hawke and McConchie, 2006). With the growth of a foredune, the change in topography may impede drainage, forming a swamp in the back dune depression (McFadgen, 1997). This depositional relationship produces a facies relationship that is easily recognisable in the geological record: fine windblown dune sand, often with root structures, and dark, organic-rich, sandy swamp deposits (Wright, 1988).

The Kāpiti Coastline is classified as a dissipative coastline (Finkl, 2004). A dissipative coast is classified for its gradually shallowing shoreface. In periods of incident swells this sea floor leads to a wide surf zone of breaking waves as the sea floor interacts with the concave up shelf slope (Boggs, 2011).

The offshore sedimentary divisions of the foreshore and shoreface form sedimentary structures that are a result of the processes influencing that environment (figure 2.4). As the shoreline progrades, these once laterally adjacent units become vertically successive in accordance with Walther's law (Middleton, 1973). On a prograding coastline such as the Kāpiti Coast, interpretations of the vertical succession is anticipated to reflect once horizontally adjacent environments. 
Figure 2.4: A cross section of the beach and nearshore environments similar to that of the Kāpiti Coast. The typical sedimentary structures that are associated with these sedimentary subdivisions is shown. From Boggs (2011).

\subsubsection{Previous Paleotectonic Work}

Due to the comparatively short record of modern GPS monitoring of ground movement, paleoseismicity studies from throughout the region have been undertaken to analyse the geological record for changes in environments that are attributed seismic events. The earliest identification of uplift in the Kāpiti Coast was recognised as part of studies on geological features of the region. A deposit of wave washed stream sediments, that had been uplifted above the present day high tide line were observed by Adkin (1951). These were recognised as a record for uplift at the southernmost extent of the Kāpiti Coastal Plain (figure 2.5). Further north, a shallowing marine sequence was identified by Te Punga (1962) $10 \mathrm{~m}$ up a bank face. Located $3 \mathrm{~km}$ from the present day shoreline (figure 2.5), this outcrop contains a shoreface to dune sequence, the upper parts of which were radiocarbon dated to greater than $45 \mathrm{ka}$. These two deposits suggest uplift proximal to the axial range. 


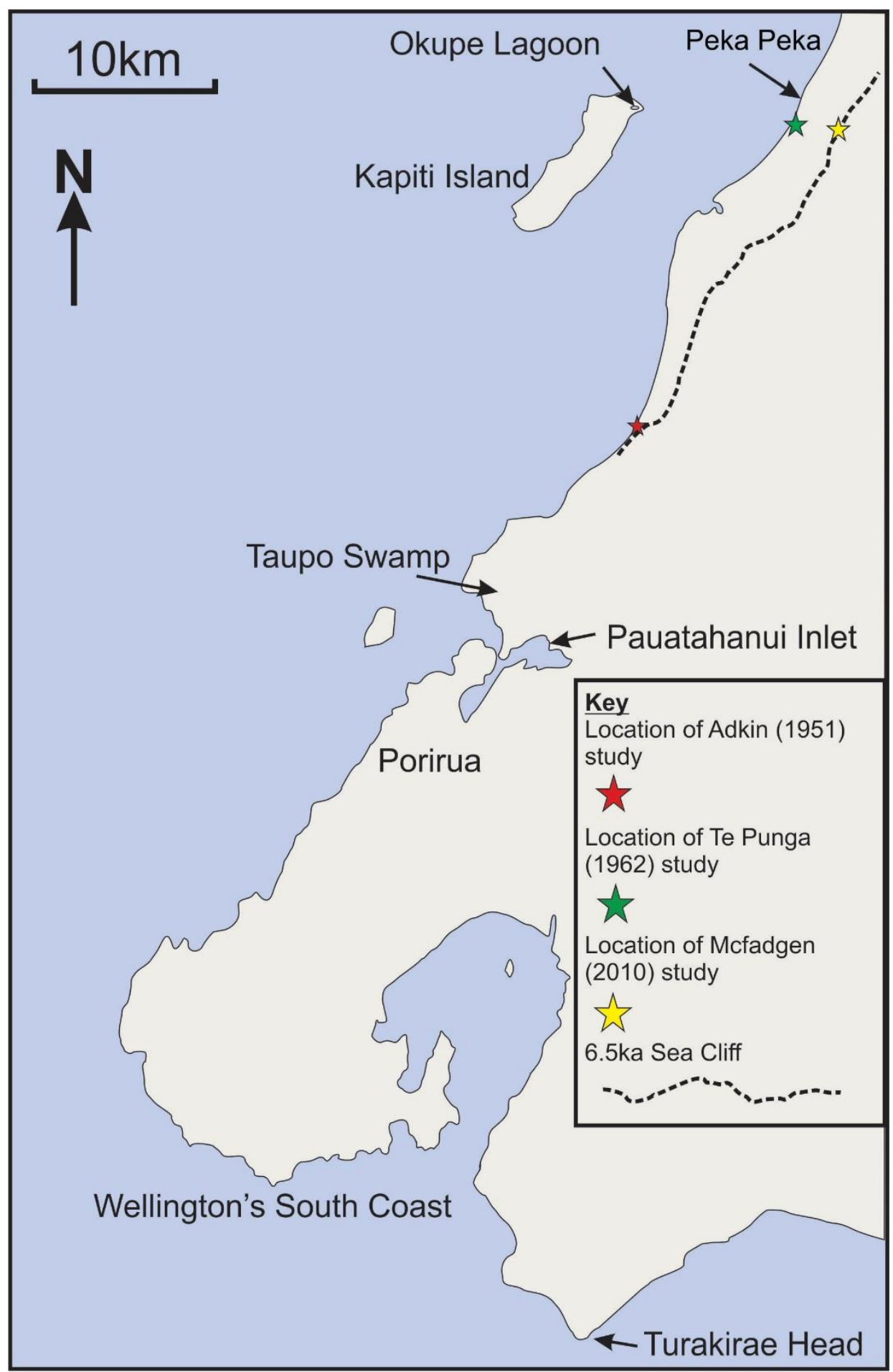

Figure 2.5: Locations of previous paleotectonic studies on the Kāpiti Coast (stars) and the Greater Wellington Region.

The movement of local faults may be the source of some of this uplift, with the Ohariu Fault (figure 2.1) passing close to the edge of the Coastal Plain. It has been trenched to study its past movements (Litchfield et al., 2006, Litchfield et al., 2004). The Ohariu Fault's most recent movement is estimated as a magnitude 7 earthquake, causing a surface rupture of at least $55 \mathrm{~km}$ (Litchfield et al., 2004). This event occurred 1050-1000 years calBP, the third rupture of the Fault with in the last 6000 years (Litchfield et al., 
2006). McFadgen (1980) found the movement along this faultine to be synchronous with the well-documented series of uplifted beach ridges at Turakirae head (Wellman, 1967) (figure 2.5) and estimates the vertical uplift in the Pauatahanui Inlet area to range between 1-2m since 6250 years BP (McFadgen, 1980). Studies of changes in micropaleontology assemblages by Cochran (2002) from cores of the Okupe lagoon on Kāpiti Island and the Taupo swamp in Plimmerton, reveal large uplifting earthquakes which affected the wider Wellington Region and as a result the Kāpiti Coast (Cochran et al., 2007). A study on the Porirua Harbour south of the Kāpiti Coast concluded uplift rates of $0.9 \mathrm{~m} / 1 \mathrm{ka}$ for Plimmerton while $1.2 \mathrm{~m} / 1 \mathrm{ka}$ was found for the inner Porirua Harbour (Gibb and Cox, 2009).

Work by McFadgen (2010) suggests that the Peka Peka area (figure 2.5) has subsided based on a change in snail species, from dry land snails to lagoonal species, with a peaty swamp soil developed above, as well as other evidence nearby of a change from dry to wet environment. This was supported by a shoreline deposit of driftwood and pumice buried 1-2m below another shoreline deposit of the same material, with both deposits suggesting that the area has undergone subsidence (McFadgen, 2010). The timing of this is estimated by McFadgen (2010) to be between 400-600 years BP. McFadgen's work is supported by a subsurface geophysical study (Ewig, 2009), revealing a subsiding pull apart basin beneath Peka Peka, north of Waikanae Beach. The origin of this pull apart basin is a stepped strike slip fault system occurring amongst the North Island dextral fault belt. This local fault system is associated with the complex stress regime of the subsiding southern South Wanganui Basin and the uplifting Tararua Range (Ewig, 2009).

Sediment cores from Okupe Lagoon on Kāpiti Island, provide a record for environment changes and impacts for Kāpiti Island during the Holocene. This includes two catastrophic saltwater inundations, such as exceptionally large storm surges or tsunamis (Goff et al., 2000). At least one of these events is a tsunami dating from the $15^{\text {th }}$ century, which caused major erosion and destabilisation of the dunes on the Kāpiti Coast, this sand was then remobilised to form the large coalescing dunes found on the southern limb of the Kāpiti Coast (Goff et al., 2007).

The large scale tectonics for the Kāpiti Coast is well understood, positioned across the convergent Pacific-Australian plate boundary (figure 2.2). However the tectonic motion 
of the Kāpiti Coast is still uncertain, contrasted between the recognition of subsidence in the Peka Peka area (Ewig, 2009, McFadgen, 2010) and the evidence for uplift on the inner margins of the coastal plain (Adkin, 1951, Te Punga, 1962). Further work is needed to define the regional tectonic setting of the coast to determine the long term impact of this on the Kāpiti Coast.

\subsubsection{Climate and Tide}

The Kāpiti Coast often receives strong westerly winds from the Tasman Sea, which are driven by the prevailing wind belt in the southern hemisphere. Annual rainfall for the area reaches around $1000 \mathrm{~mm}$ at sea level to $>2000 \mathrm{~mm}$ in the Tararua Ranges (Baldi et al., 2007). While the climate for the coast is generally subdued with warm summers and mild winters, extreme weather events are not uncommon, some capable of delivering over $100 \mathrm{~mm}$ in a 24 hour period, causing major disruptions to local transport and urban areas (Hancox, 2003). Tidal movement for the Kāpiti Coast is moderate for the majority of the year, however during spring tides the Kāpiti Coast can experience up to $1.9 \mathrm{~m}$ of tidal change (LINZ, 2017a, LINZ, 2017b).

Wind and westerly swells reach the coastline from the Tasman Sea producing a moderate wave climate (Wright, 1988) with swells terminating along the coastline as they move southwards towards Cook Strait (Lewis, 1979). South of the Paraparaumu cuspate foreland, the coast receives a southerly wind and resultant swell from the Cook Strait (Chiswell and Stevens, 2010). Due to the limited fetch, this southerly swell is moderate at best. However, the primary current for the coastline is a southwards moving drift (Chiswell and Stevens, 2010), driven by the d'Urville Current as it moves south along the coast through Cook Strait (Brodie, 1960).

\subsubsection{The Kāpiti Coast Dune Field}

The dominant landform feature for the Kāpiti Coast is the extensive dune field that comprises the mostly flat coastal plain, with some dunes reaching up to $30 \mathrm{~m}$ in height. The shape of the dunes vary from low parallel dunes to parabolic and coalescing dunes. The shape of the dunes depends on local factors such as sediment supply, wind strength and direction or local events such as tsunamis (Cowie, 1963, Goff et al., 2007).

The dunes nearest the coastline towards the north of the Kāpiti Coast show a welldefined, shore parallel arrangement of low dunes. These are recent foredunes that are formed from shoreface sand and then subsequently abandoned as the shoreline 
moves seaward. These are most prominent south of the Otaki and Waikanae rivers, both large, sediment bearing rivers. Wright (1988) suggested that the wind shadow effect of Kāpiti Island led to the subdued relief seen in the vicinity of Paraparaumu Beach. North of Paraparaumu, at Waikanae Beach, the uninterrupted wind flow has led to the development of dunes that are considerably higher.

Parabolic and coalescing dunes form on coasts which receive less sediment, such as the southern portion of coast from Wharemauku Stream towards the Te Pari Pari cliffs. This portion of coast tends to form dunes that are not shore parallel and instead coalesce to form large mounds with blowout bowls, and some faintly visible parabolic dunes. Some of the large cross bedded dunes have led to them being labelled marine deposits (Oliver, 1948, Adkin, 1951). This work was prior to the recognition that the Kāpiti Coastal Plain resulted from a prograding coast and dune deposition following deglaciation (Te Punga, 1962).

Previous work on the dunes of the Kāpiti and Manawatu Coast have worked to separate the dunes into phases related to their age and location, these classifications are primarily based on the Manawatu coastline but have been used to describe some of the development on the Kāpiti Coast (Cowie, 1963, Muckersie and Shepherd, 1995, Wright, 1988). Initially the sandy plain was described as an uplifted inner shelf deposit (Oliver, 1948), with some reworking of material to form dunes and shoreline sands, with no consideration for sediment supply. The commonly used phases for the dunes in the area were determined by Cowie (1963), who divided them into four phases. The oldest is the Koputaroa Phase, in the Kāpiti Coast their extent is restricted to north of Waikanae. Using OSL dating, the Koputaroa Dunes have been shown to be mobile up to $10 \mathrm{ka}$ (Hawke and McConchie, 2005), the majority of this phase is likely to have been remobilised into the more recent sequences as global sea level rose towards its present level (Gibb, 1986), this remobilisation of sediment would have incorporated the existing terrestrial dune surface into a marine environment (Hawke and McConchie, 2005). The remaining Holocene dune sequences and their ages are: Foxton Phase (6.5-1.6ka), Motuiti Phase (1-0.5ka) and Waitarere Phase ( $<120$ years) (Clement et al., 2010). Following the eruption of Taupo 1764 years BP (Wilson, 1993), pumice from this event deposited on the shoreline was incorporated into the Foxton Dunes, forming the Taupo Dune Sand (Muckersie and Shepherd, 1995). 


\subsubsection{Modern Sedimentary System}

As the Kāpiti Coast district is a low lying coastal plain (Davis, 2012), its deposition is a result of combination of prograding coastal sedimentation in the form of dunes and fluvial deposition (figure 2.1). The Kapiti Coast's sedimentary budget is divided into a northern and southern segment, divided at Paraparaumu Beach. The northern segment of coastline is presently depositional and is considered a prograding coast (Gibb, 1978a). The southern segment of coastline has become starved of sediment by the growth of the cuspate foreland and has become erosional with scarped dunes a common sight (Gibb, 1978a). The commencement of erosion along the southern segment of the Kāpiti Coast is interpreted to have begun between the Taupo eruption of 1764 year BP (Wilson, 1993) and modern surveying in the year 1874 (Gibb, 1978a)

With the coastal lowland a result of Holocene sedimentary accretion, the source of the sediment is predominantly the rivers draining the Wanganui and Manawatu regions as well as the Taranaki coastline (Cowie et al., 2009, Kasper-Zubillaga et al., 2007, Gibb, 1978a). This sediment is transported towards the Kāpiti Coast by the dominant southerly longshore drift, combined with the influence of the d'Urville current. Some locally sourced sediment originates from the Otaki and Waikanae rivers (Griffiths and Glasby, 1985). This longshore transport is evident in the well-sorted grainsize and uniform composition of sand seen on the shoreline (Gibb, 1978a, Kasper-Zubillaga et al., 2007). The dissipative coast's wide surf zone causes entrainment through interaction with the gradually shallowing seafloor (Finkl, 2004), the effect of this is heightened during periods of greater swell. These storm events cause extensive sediment entrainment in the nearshore environment, and combined with ocean currents play a major role in the longshore transport of sediment (Davis, 2012).

The progradation of the cuspate foreland at Paraparaumu has formed a barrier to the transport of sediment to the southern segment of the Kāpiti Coast (Gibb, 1978a). With the significant reduction in the influence of the southward longshore drift to the southern Kāpiti Coast, Gibb (Gibb, 1978a) recognised a northward longshore drift operating along shoreline (figure 2.1). The presence of this return current was recognised through current observations and a northward improvement to the sorting of sand on the shoreline of the southern Kāpiti Coast (figure 2.6). In addition to the grainsize observations a number of the small streams on this segment of coast have 
stream mouths that have been orientated to the north, by the deposition of northward moving sediment (Shand, 2012). Construction of the road at the foot of these hills may limit the supply of sediment to the coastline (Gibb and Depledge, 1980).

A grain mineralogy study on sand samples from the Kāpiti Coast by Kasper-Zubillaga and Dickinson (2001), revealed a composition dominated by grains of lithic fragments. Quartz and feldspar compose the remainder of the samples with variation influenced by some environmental factors (Kasper-Zubillaga and Dickinson, 2001).

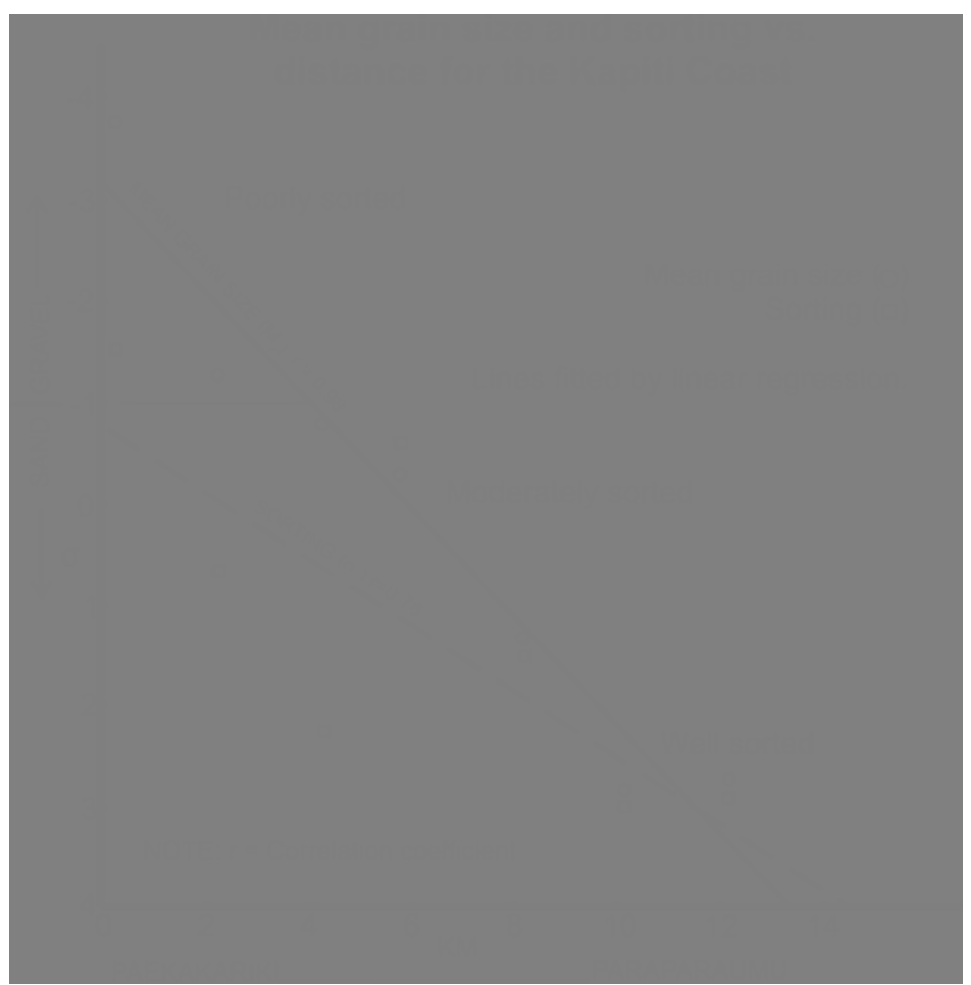

Figure 2.6: Graph showing mean grain size for samples collected along a $12 \mathrm{~km}$ length of shoreline on the southern Kāpiti Coast, from the Te Pari Pari cliffs (0km) to Paraparaumu $(12 \mathrm{~km})$. Demonstrating the northward sorting of the southward longshore drift. Reproduced from Gibb (1978a). 


\subsubsection{5ka Sea Cliff}

Following the end of the Last Glacial Maximum, global sea level rose to its present level (figure 2.7). As this marine transgression flooded the continental shelf to its present level, wave energy eroded the coastline (Evans, 1979) forming a sea cliff. In the Kāpiti Coast, this is seen as the cliff of a paleo shoreline (figure 2.5), most prominent between Otaki and Waikanae (Te Punga, 1962), but it is also recognisable south towards Paekakariki as the boundary between Holocene dune sands and the escarpment. In some places the Torlesse sandstone rock of the Tararua Ranges is the material forming the cliff, while elsewhere it is the sediment at the foot of the hills, fluvial or marine in origin. Near to Peka Peka, Ewig (2009) suggests that the shape of this sea cliff at this location may be a result of faulting associated with the North Island dextral fault belt. The cliff was first identified by Te Punga (1962) who recognised that the trace of the cliff matched that of the shoreline with impressive similarity, despite the nearly $4 \mathrm{~km}$ of Holocene coastal aggradation. Te Punga's study described and dated an outcrop in a stream bank that cut through the cliff north of Waikanae, revealing a radiocarbon age of greater than 45,000 years, suggesting the cliff was cut into an aggradation plane that formed prior to the Holocene transgression. The timing of this transgressive erosion event ceased 6.5ka ago, as sea level reached its maximum height and coastal accretion began (Te Punga, 1962, Hawke and McConchie, 2005). This sea cliff provides a marker line, against which the late Holocene sediments of the coast have accumulated. 


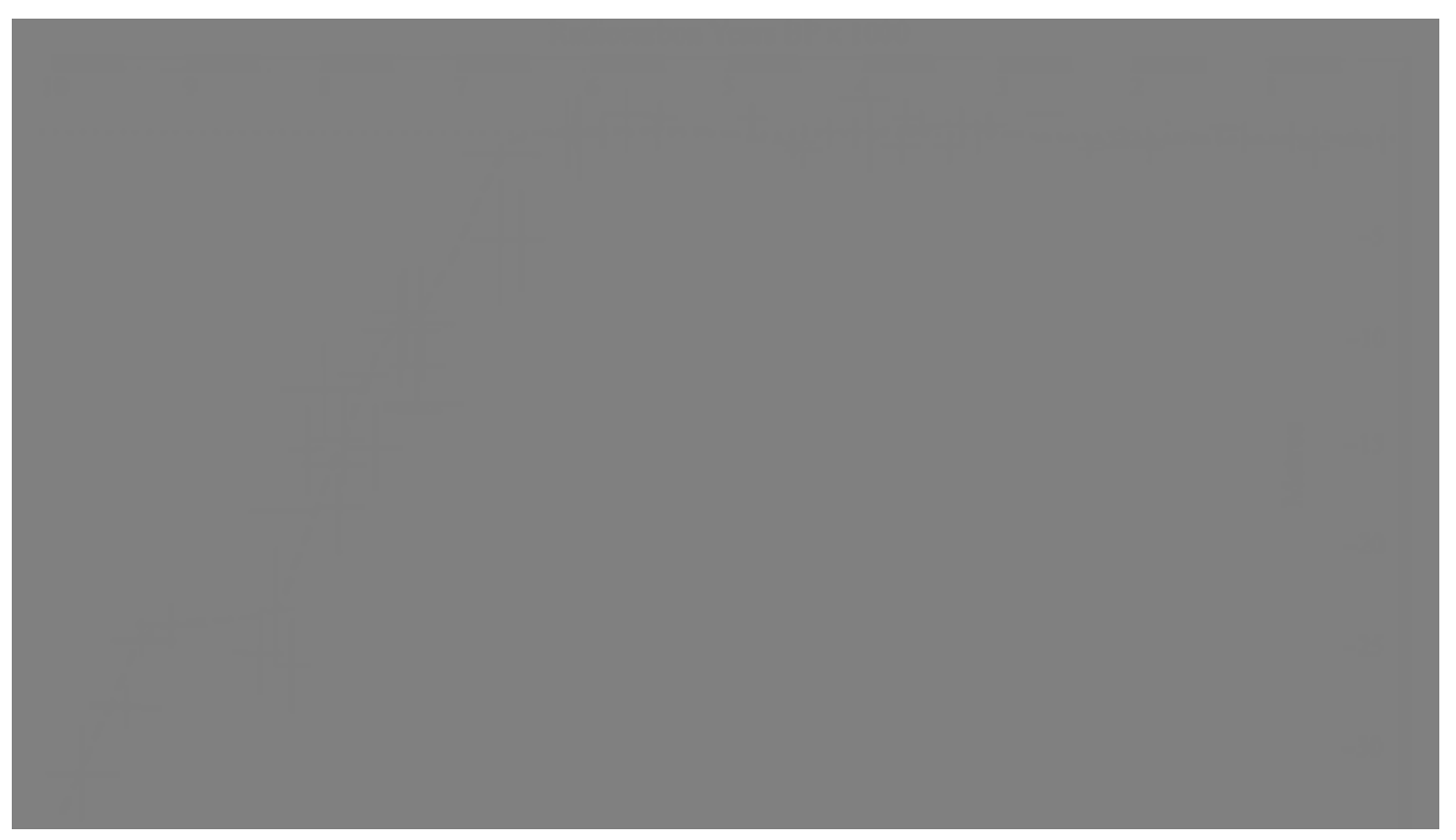

Figure 2.7: A regional sea level curve for New Zealand during the recent deglaciation. Markers indicate sea level height and timing for coastal locations around New Zealand, uncertainty is shown by the length of the lines. Image from Kennedy (2008), compiled by Gibb (1986). 


\section{Methods}

This study examined six cores and three outcrops, as well as a transect of a modern beach/dune environment. Coring was undertaken using a track mounted sonic coring drill rig and a short hand driven auger, while outcrops were measured with surveying equipment. The laboratory preparation and analysis of samples for grainsize, mineralogical composition and roundness as well as the logging of cores was performed using facilities at Victoria University of Wellington. Radiocarbon dating was performed at Waikato University and GNS, while optically stimulated luminescence dating was undertaken at Victoria University of Wellington.

\subsection{Coring}

\subsubsection{Sonic Rig Corer}

The WS3 core was collected using a track mounted sonic drill rig owned and operated by Webster Drilling (figure 3.1). The rig uses a variable vibration, with a small component of rotation to penetrate the surface. Each run was drilled to its target depth, the pipe was then detached from the rig and left at the bottom of the hole, drill hole casing was then advanced to the same depth as the drill pipe to prevent cave ins once the drill pipe was removed.

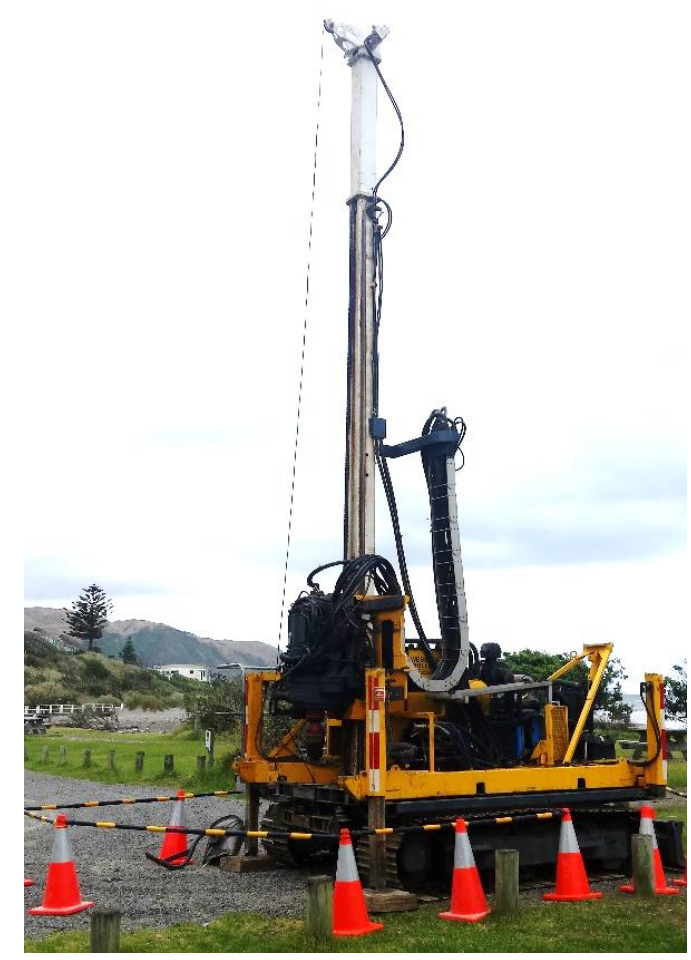

Figure 3.1: Webster Drilling's track mounted sonic drill rig on the site of the WS3 core. 
The end of the core barrel had a core catcher to prevent core sample from falling out of the barrel. The core was collected in $1.5 \mathrm{~m}$ runs, with casing advanced to the depth of $20.2 \mathrm{~m}$. Drilling was then done in $3 \mathrm{~m}$ runs from $20.2 \mathrm{~m}$ to $29.2 \mathrm{~m}$, with open hole as there was insufficient casing. Due to weight of the $3 \mathrm{~m}$ runs on the core catcher, the bottom $200 \mathrm{~mm}$ of core was lost as the drill barrel was extracted. Water was pumped through the drill barrel as it was lowered at the beginning of each run to ensure that no cave in material was collected in the drill barrel. Upon removal of the drill barrel at the end of the run, the collected portion was vibrated into a length of lay flat plastic (figure 3.2). This was then cut open and the core was placed between $60 \mathrm{~cm}$ length sections of core tray. Markers for true depth were placed in the trays prior to the core being boxed for transport.

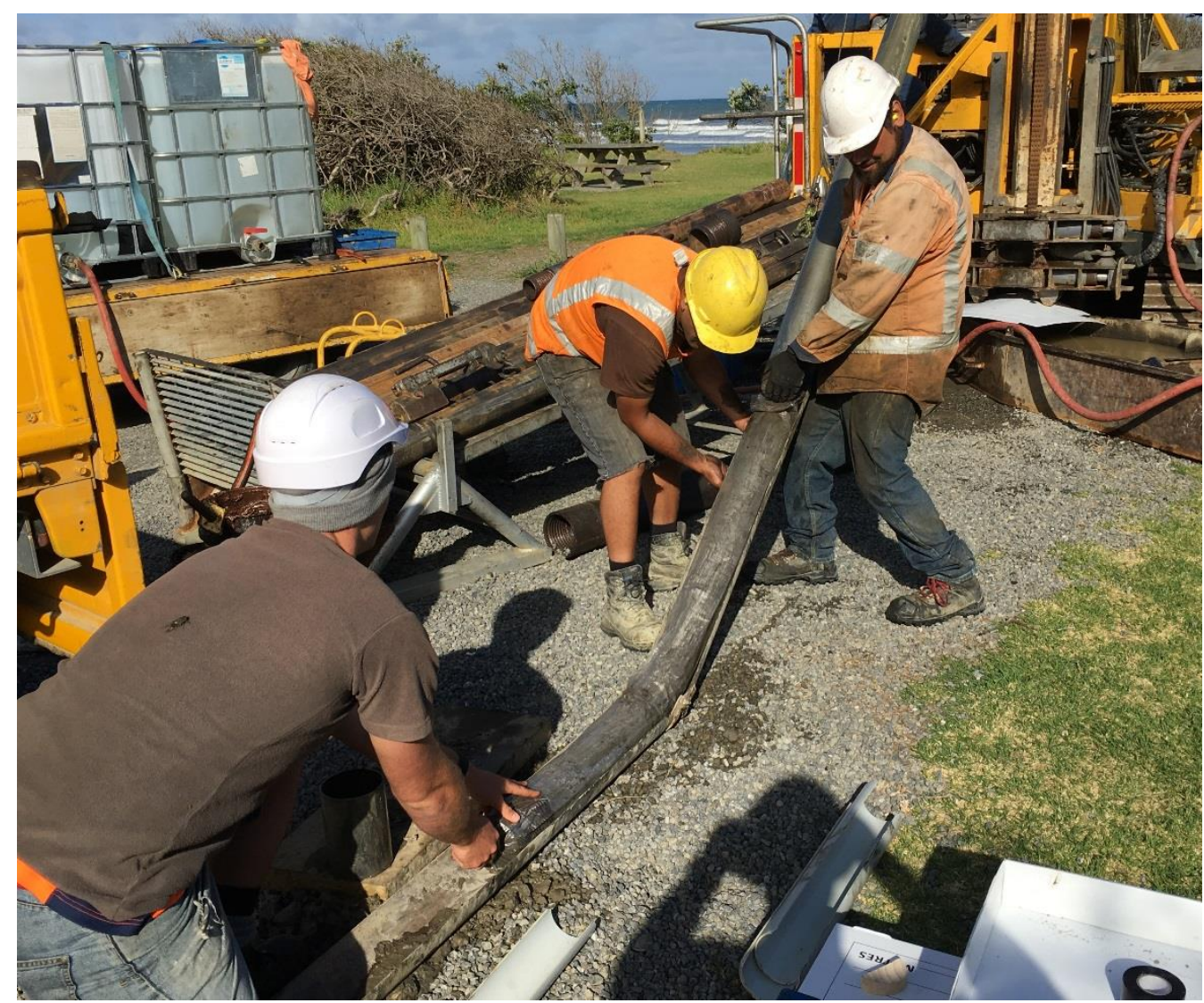

Figure 3.2: Removal of the sample from the drill barrel. Following a collection run, the drill barrel is seen here in the position for removal of the sample. The sample is extruded from the core barrel into the lay flat by vibrating the drill pipe. 
To allow description, the core was cut in half using a length of thin wire, pulled from top to bottom between the two core trays (figure 3.3). Some distorting of the core occurred on larger material within the core such as shells, pebbles or wood as they were slightly displaced down core. Despite this the rest of the core appeared intact with laminations and other bedding features well defined.

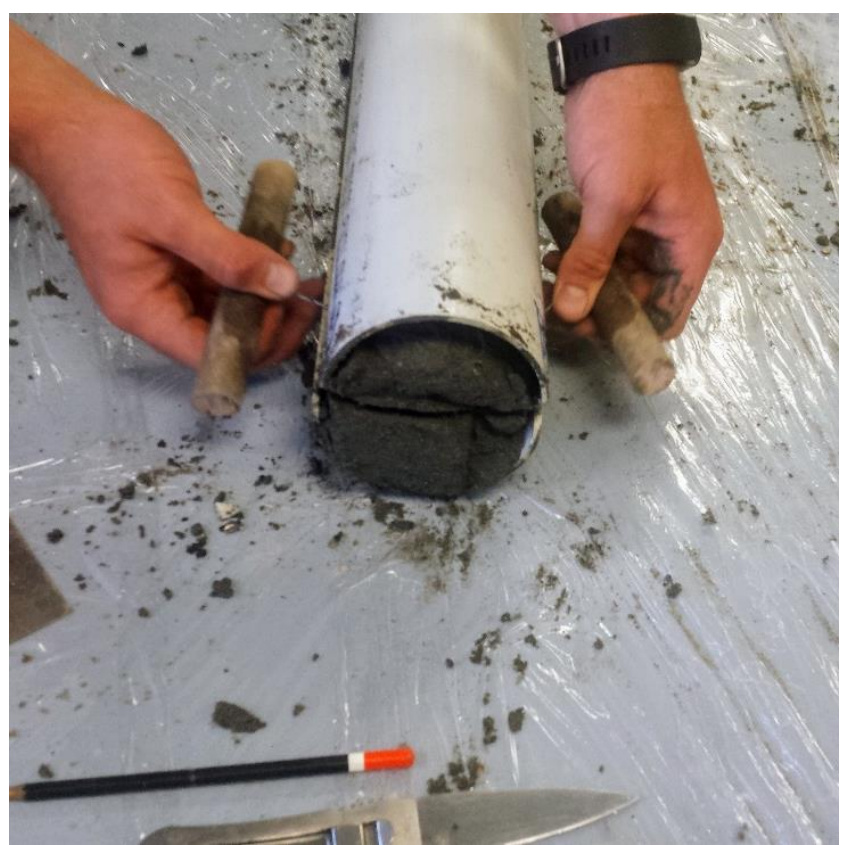

Figure 3.3: Splitting the core. A portion of the WS3 core seen here between two plastic core trays. To split the core, a thin piece of wire is firmly pulled from top to bottom.

The geotechnical company provided the cores $A B 1, A B 2, A B 3 \& A B 4$ to this study after being collected for a subsurface geotechnical investigation at the Kāpiti Airport. These cores were collected using the same drill rig as the WS3 core.

\subsubsection{Core Logging}

The process of logging the cores WS3, $A B 1, A B 2, A B 3$ and $A B 4$ was performed in the facilities at Victoria University of Wellington. All cores were described for their full length manually against a measuring tape, core depth markers were used to check the accuracy of the core description where available. Samples for grainsize were taken from all cores, with locations selected to best represent the lithologies and the variability of grainsize along the core. Samples were collected from the $A B 1, A B 2$ and AB4 cores for point counting. Throughout the description, the cores were sprayed with water regularly to maintain a uniform colour and to prevent loss of cohesion due to drying. 


\subsubsection{Auger Corer}

The WS1 core was taken with a hand driven, rotary auger soil sampling tool. This core was taken as an investigative core for the Wainui Stream area. Once the auger had been driven the depth of the collection chamber, it was removed and the collected sample was laid in stratigraphic order for description and sampling. As this method gives little in the way of core consolidation, and as a result the contacts are not clear in the core, the stratigraphic height of the layers are estimated to be within $\pm 5 \mathrm{~cm}$ of actual height.

\subsection{Measured Sections}

For the Fisherman's Table and Pickle Pot locations, measured sections were taken of outcrops on the beach. These sites are within the eroding southern portion of the Kāpiti Coast and the outcrops occur in scarps formed by the oceans erosion. The Te Pari Pari outcrops were measured using a $4 \mathrm{~m}$ surveying measure for the steep faces while a $1.5 \mathrm{~m}$ Jacobs staff and abney level were used for the less inclined sections. The short Pickle Pot section was described using a $5 \mathrm{~m}$ tape measure

The Jacobs staff and abney level were also used at the Te Pari Pari outcrops to determine the elevation of the section above maximum low tide. This was undertaken using the tide tables produced by Land Information New Zealand (LINZ, 2017a, LINZ, 2017b)

\subsection{Beach Transect Survey}

The Waikanae Beach transect is a profile survey of the dune-beach transition along a shore normal profile running from the back dune to the mid tide level. The measurements for the transect were undertaken using a dumpy level at a fixed position along the transect and $4 \mathrm{~m}$ surveyors ruler positioned at the sample site. To calculate the elevation of sample sites, the dumpy level was positioned at a fixed elevation on the dune crest. The surveyors rule was positioned vertically and the height difference was recorded. Horizontal distance was measured between sample sites along the transect line using the $4 \mathrm{~m}$ surveyors ruler. 


\subsection{Sampling}

Throughout the describing process, samples were collected for grainsize, point counting, dating or later examination. Samples taken from the cores were collected as $2 \mathrm{~cm}$ wedges of core slices to eliminate any bias due to horizontal sediment movement within the core. Units of sand were the focus for sampling, as it is the most common lithology making environmental changes most visible. Each description site of the transect was sampled from $5 \mathrm{~cm}$ deep at each location, an $8 \mathrm{~cm}^{3}(2 \mathrm{~cm} \times 2 \mathrm{~cm} \times 2 \mathrm{~cm})$ block was collected. Sampled material was then placed in labelled plastic bags.

Four samples from the WS3 core were dated using optically stimulated luminescence (OSL). To prevent the compromising of the samples, collection was performed in the OSL dark room facilities at VUW. Samples for radiocarbon dating were collected from the cores and placed in plastic bags, before being submitted for analysis.

\subsection{Laboratory Work}

\subsubsection{Grainsize}

Grainsize samples were dried in an oven set to $50^{\circ} \mathrm{C}$ and then weighed to determine a total dry sample weight. They were then sieved using a $1.4 \mathrm{~mm}$ sieve to remove larger particles prior to further detailed analysis. The majority of samples were able to be sieved by hand and an Endecotts Octagon $200 \mathrm{CL}$ sieve shaker was used when the sample was not suitable for hand sieving. Sieve shaker samples were run for five minutes with an amplitude of 0.5 with an intermittent vibration setting. The coarsest portion of the sample was separated and weighed.

Prior to analysis the samples were split into smaller portions using small riffle splitters. This method was tested for consistency with the AB1-11.0 sample which was split into three separate fractions and run through the LPS to test the reproducibility of the splitting. The sample distribution varied by no more than $3 \%$ between sand and mud fractions for each sample (figure 3.4).

Once split, the samples were placed in a beaker with $0.5 \mathrm{~g} / \mathrm{L}$ calgon to prevent aggregates, and stirred to suspend the sediment. Beakers were then placed in an ultrasonic bath for 3 minutes, sediment stirrers within the beaker kept the sediment suspended. Samples were stirred with a spatula to keep the sediment suspended prior to being placed in a Beckman Coulter Laser Sizer 13 320. The sample and its liquid 
were added into the sample bowl. Beaker and spatula were rinsed into the collection bowl with deionised water to ensure all sample was analysed.

The raw grainsize data was analysed using the Gradistat program (Blott and Pye, 2001), values of which are presented in microns. The samples analysed for this study are discussed in the following chapters, and all grainsize data is presented in Appendix 1 beginning on page 138 .

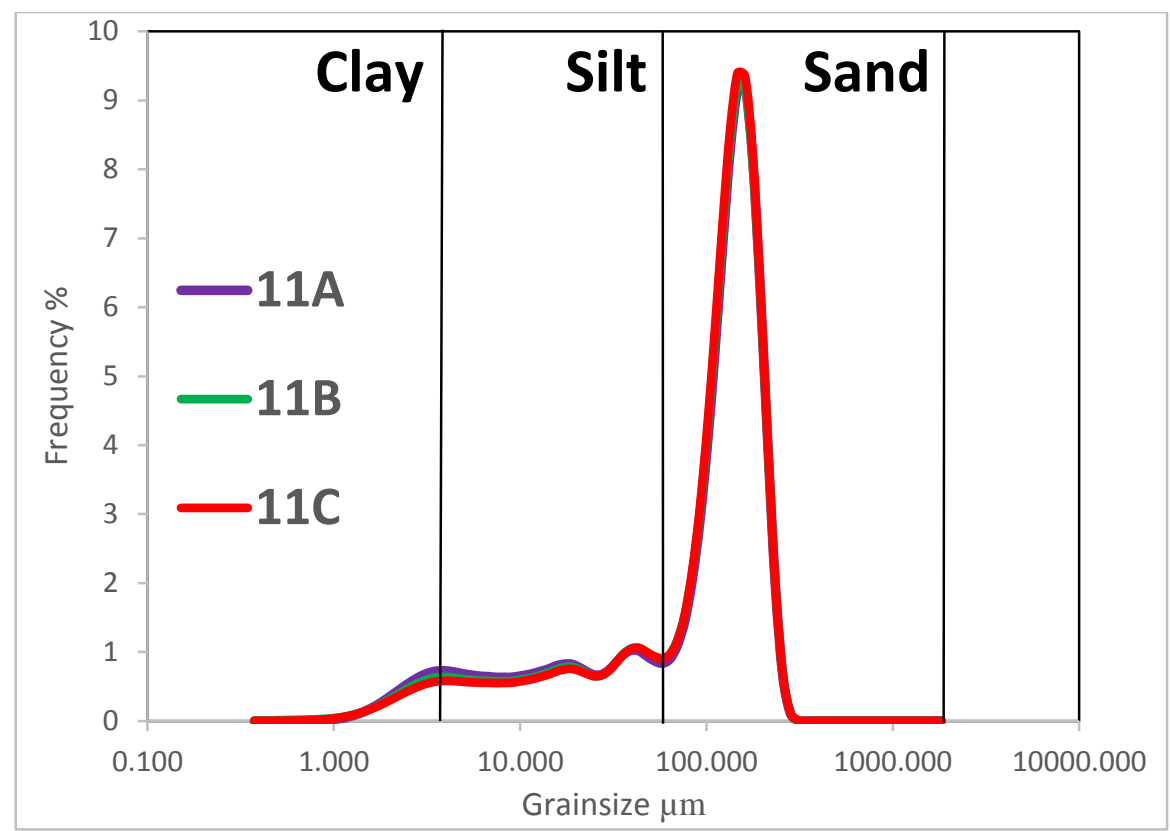

Figure 3.4: Three samples were split from the AB1-11.0 sample to demonstrate reproducibility of this sample splitting method, this graph shows that splitting the sample three times alters the percent mud and sand composition of the sample by less than $3 \%$ each.

\subsubsection{Point Counting}

Using a separate portion of the samples collected for grainsize, slides were mounted for point counting. Grain roundness and mineralogy of each grain was determined from the slides. Roundness was determined using the Powers (1953) roundness scale. Grain mineralogy was determined using the optical properties and appearance of the grains.

In preparation for mounting the samples were split using nested sieves on the same sieve shaker and settings used in the grainsize process. The 125-250 $\mu \mathrm{m}$ (fine-sand) portion of the sample was retained as this is size fraction used by Shepard and Young 
(1961) to determine the roundness differences of beach and dune sands. Samples were mounted on glass slides using Canada balsam and covered with a glass cover slip.

Point counting was performed on an optical mineralogy microscope fitted with a point counting stage, which moved the slide in a grid square pattern beneath the objective lens. Slides were blindly labelled for analysis to prevent a bias of the results. Grains were only counted when the microscope crosshairs intersected a grain. A minimum of 300 counts were performed for each slide. Mineralogical composition values were normalised to $100 \%$. Grain roundness was calculated for each grain as well as a sample average. All mineralogy and roundness data is displayed in Appendix 2 beginning on page 157.

\subsubsection{Age Control}

Samples from this study were dated using optically stimulated luminescence (OSL) and radiocarbon dating methods. The OSL dating was undertaken at Victoria University's luminescence dating facility. Radiocarbon dating was performed at Waikato University and the Institute for Geological and Nuclear Sciences radiocarbon dating facilities. Radiocarbon and OSL ages are reported as a median with 20 uncertainty.

The OSL dating was undertaken on four samples from the WS3 core using coarse grain k-feldspar preparation technique, with the blue luminescence of the grains measured during infrared stimulation. The dose rate of the samples was determined on the basis of gamma spectrometry measurement while the ages were determined using the Single Aliquot Regeneration method.

Radiocarbon dating of the wood sample from the WS1 core was performed at Waikato University. The sample was scraped clean and then washed in an ultrasonic bath before being ground for radiometric analysis.

Radiocarbon dating of the wood sample from the AB4 core was performed at GNS's Rafter Radiocarbon Facility. The sample was cleaned and chemical treated before being analysed using the AMS

An age depth model was prepared for the Wainui Stream cores using OXcal v4.2.4 (Ramsey, 2009a) with the Southern Hemisphere Calibration SHCal13 (Hogg et al., 2013). Outliers were recognised using a simple outlier model (Ramsey, 2009b). 


\section{Results}

For this study sediment cores collected from the Wainui Stream mouth (WS1 \& WS3), Kāpiti Airport ( $A B 1, A B 2, A B 3$ \& AB4) and outcrop sections measured near Fisherman's Table and Pickle Pot (figure 4.1) have been described, and sampled. A surveyed transect was carried out at Waikanae Beach to document the dune and beach environments in a modern day prograding setting, to document the characteristics and contrasts of the transition between environments. This serves as a modern analogue for the sedimentary processes and characteristics present in the cores and outcrops. Data on the grainsize, grain roundness of samples collected is presented as well as results of optically stimulated luminescence and radiocarbon dating. Some data is presented in the appendix and is referenced as such. A key has been provided to aid in the interpretation (figure 4.2). A collated overview of the cores and outcrops from this study has been provided in Appendix 4 (page 162).

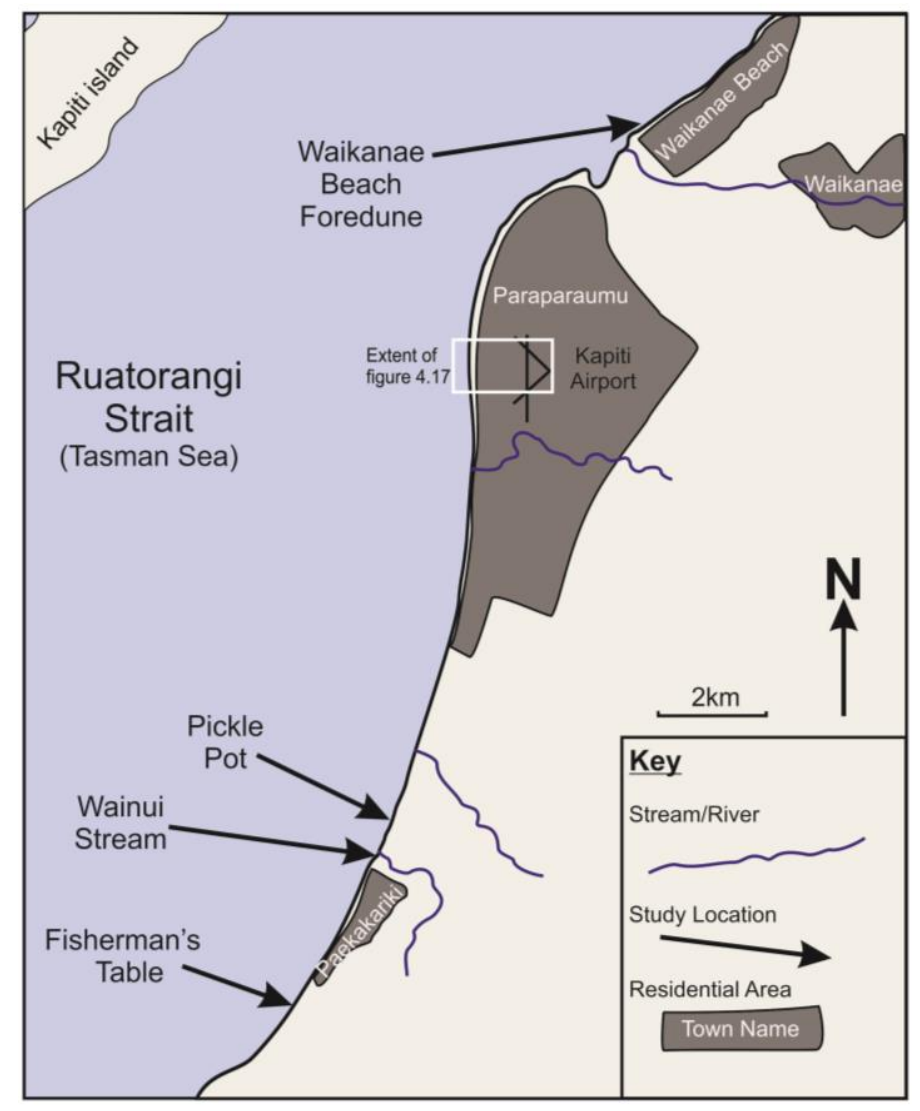

Figure 4.1: Localities of the study sites across the Kāpiti Coastal Plain. Built up areas are shown for reference. 


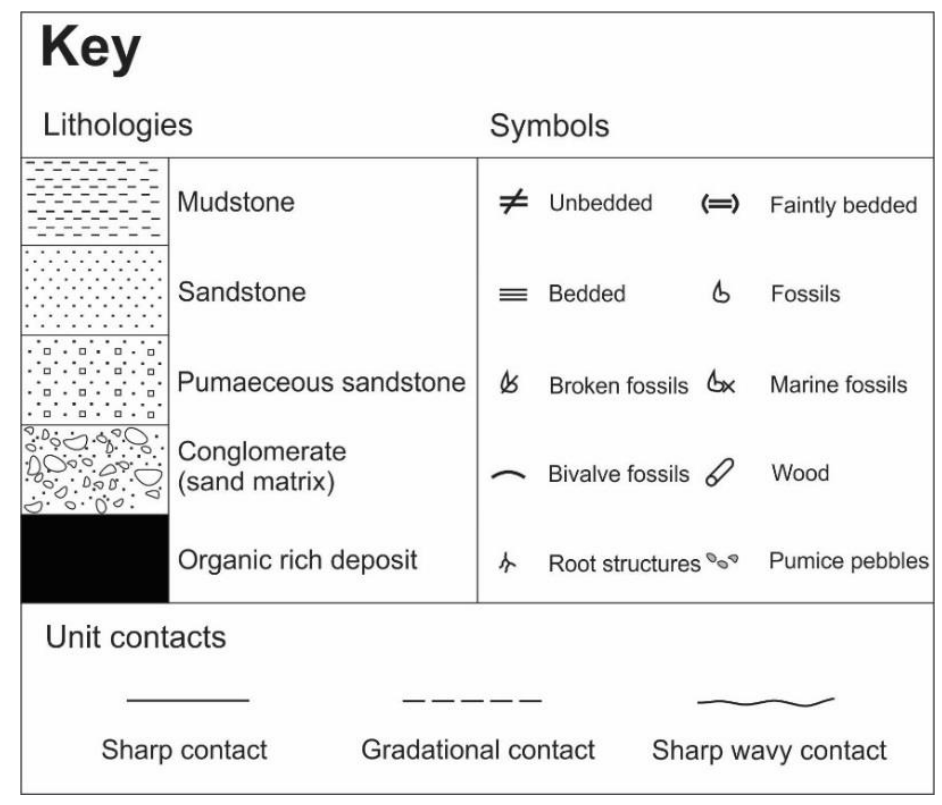

Figure 4.2: A key to the symbols used to describe the core logs and measured sections of this study. 


\subsection{Te Pari Pari Outcrops}

The Te Pari Pari Outcrops are located at the most southern extent of the Kāpiti Coastal Plain, north and south of the Fisherman's Table restaurant on State Highway 1 (figure 4.1). They are referred to as the Southern Fisherman's Table (SFT) and the Northern Fisherman's Table (NFT) and are 380m apart. Here the width of the coastal plain is less than $200 \mathrm{~m}$ and the outcrops overly the Torlesse sandstone bedrock that is seen at low tide along this part of the coast (figure 4.3).

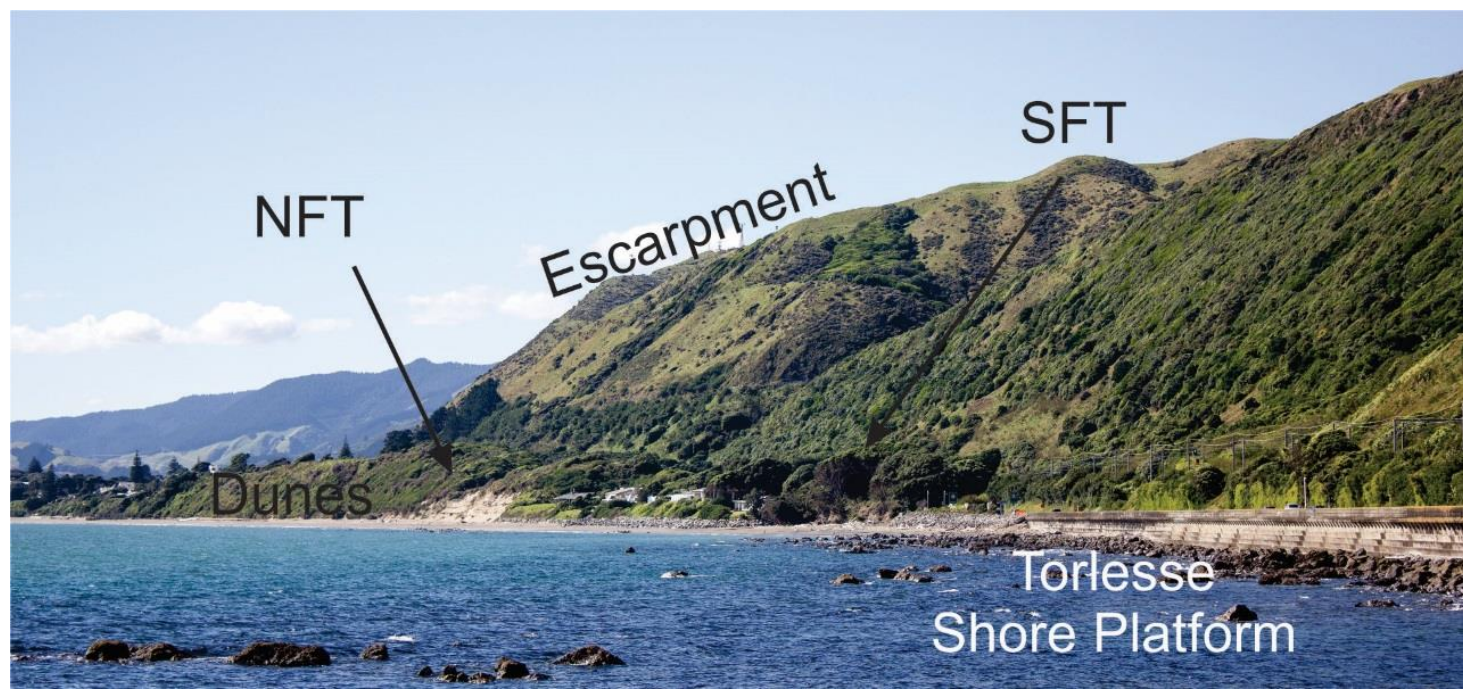

Figure 4.3: The southern portion of the Kāpiti Coastal Plain looking northeast. The Torlesse sandstone shore platform can be seen in the foreground extending towards the sand dunes at the base of the escarpment (background cliff) the Fisherman's table restaurant can be seen in the centre of the image above the beach. The NFT outcrop is within the exposed dune face to the left, while the SFT outcrop is below the trees on the right. The light-grey seawall on the lower right stands $3 \mathrm{~m}$ high. 


\subsubsection{Southern Fisherman's Table Description}

This outcrop is at the landward side of the modern beach (figure 4.4, photo; figure 4.5, measured section), located $100 \mathrm{~m}$ north of the extreme southern termination of the Kāpiti Coastal Plain at the Te Pari Pari cliffs. The outcrop is located $5 \mathrm{~m}$ south of the mouth of a small stream and $65 \mathrm{~m}$ from the base of the $6.5 \mathrm{ka}$ sea cliff. A radiocarbon date collected at this outcrop from a previous study (Fleming, 1965), was recalibrated using the SHCal13 curve (Hogg et al., 2013).

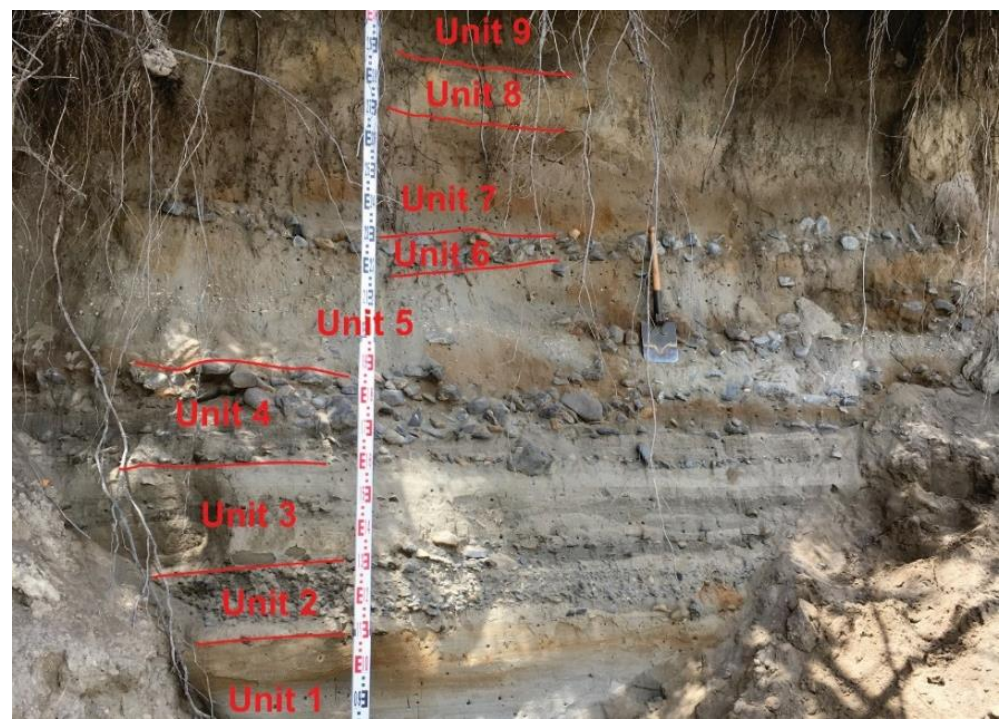

Figure 4.4: The lower portion of the South Fisherman's Table (SFT) section, containing a sequence of fine-sand and conglomerate units. Each red or black portion on the ruler is $1 \mathrm{~m}$.

The lowest unit of the outcrop (unit 1 ) is grey fine-sand with orange/brown staining of the top $20 \mathrm{~cm}$, small conglomerate lenses up to $10 \mathrm{~cm}$ thick are common, made of clasts $5-10 \mathrm{~cm}$ in size. Above this are three units of poorly-sorted conglomerate (units $2,4 \&$ 6). The clasts in these conglomerates range from angular to rounded and are up to $20 \mathrm{~cm}$ in size, occurring in a sandy matrix with visible horizontal bedding defined by changes in the matrix to clast ratio. Between the conglomerates are two sand units, the lowest of these is a brown fine-sand with horizontal bedding visible, and small Torlesse sandstone conglomerate lenses up to $10 \mathrm{~cm}$ thick (unit 3). The upper sand package is a brown fine-sand with a $10 \%$ pumice content (unit 5 ). The pumice is creamy white with occasional distinctive grey banding, these clasts are mostly well rounded (figure 4.6). The top conglomerate lacks the laterally continuous beds of the lower deposits, above this is a dark brown fine-grained sand with a high lithic grain content (unit 7). Small pumice pebbles are common up to $1 \mathrm{~cm}$ in size. 


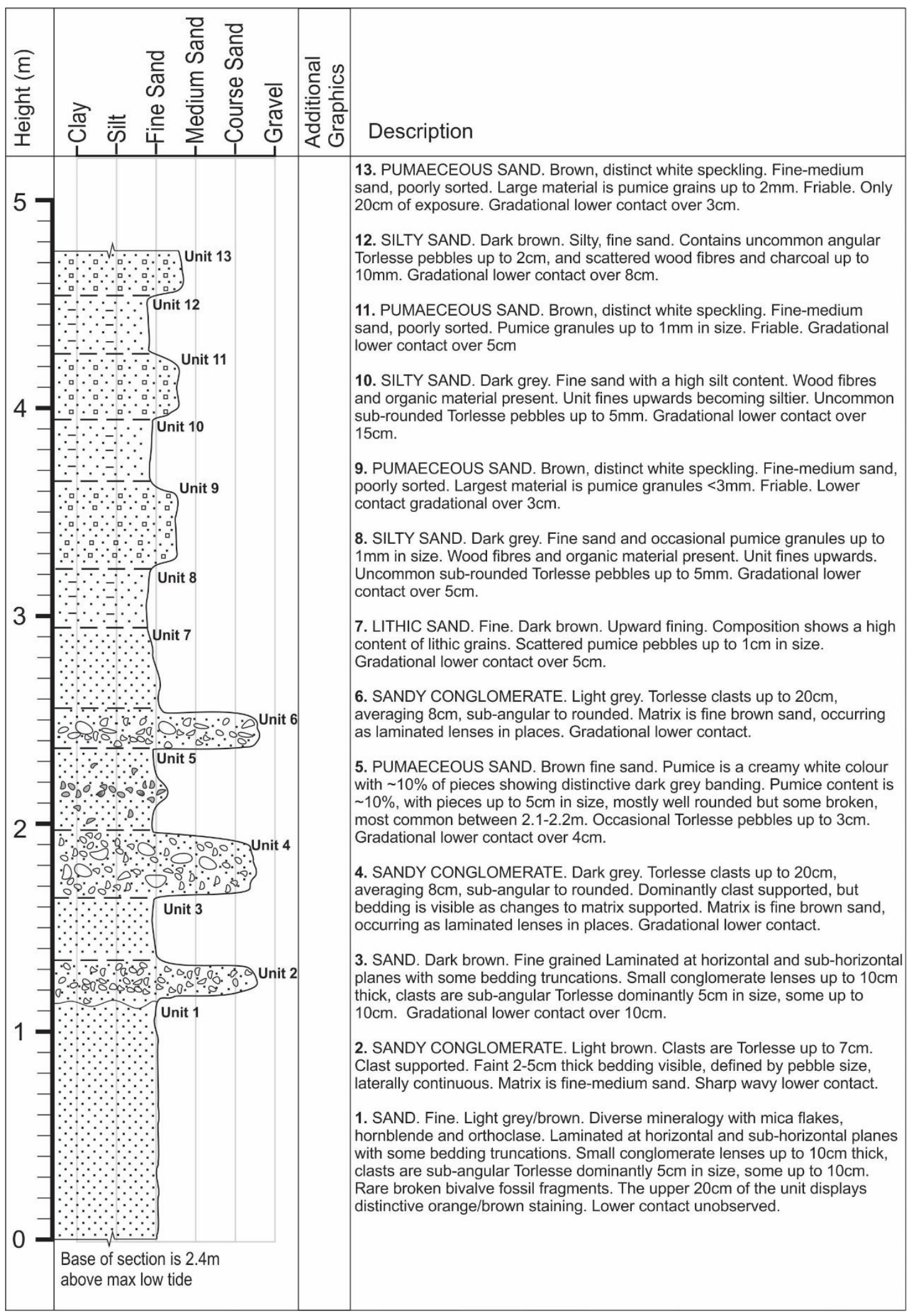

Figure 4.5: The measured section for the South Fisherman's Table (SFT) outcrop.

Thirteen lithostratigraphic units were recognised consisting of sand, conglomerate,

pumice and silts. A key to the symbols is provided in figure 4.2. 
Overlying the lithic sand is a unit of dark-grey silty-sand (unit 8), this unit contains organic material, some pumice granules up to $1 \mathrm{~mm}$ and Torlesse sandstone clasts up to $5 \mathrm{~mm}$. This unit fines upwards into a gradational contact with a pumaeceous sand (unit 9). The pumaeceous sand is brown with distinctive white speckling of pumice grains. This unit is poorly-sorted with grains up to $3 \mathrm{~mm}$ in size.

The sequence of silty-sand followed by a pumaeceous sand is repeated twice above this with small variations (units $10,11,12 \& 13$ ). The uppermost pumaeceous sand unit is capped with modern soil and root systems.

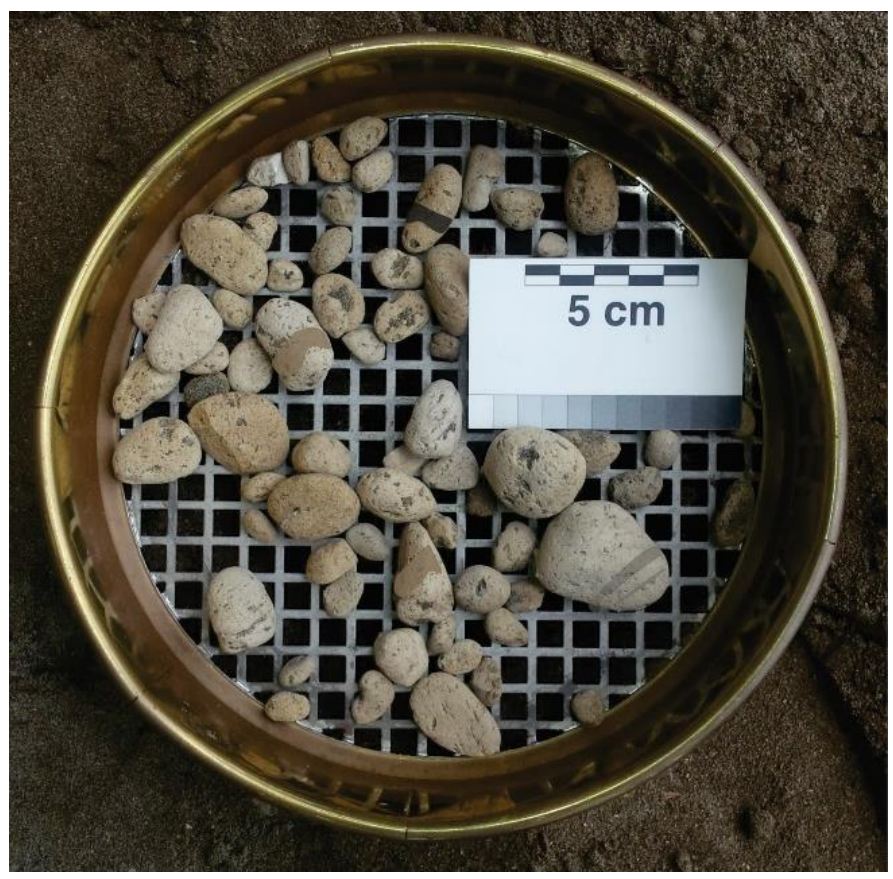

Figure 4.6: The clasts from the lowest pumaeceous sand in the NFT section. The clasts are well rounded and some are banded a darker brown or grey colour. 


\subsubsection{Northern Fisherman's Table Section}

This measured section was taken through a $10 \mathrm{~m}$ high outcrop in an eroding, shoreline dune scarp (figure 4.7) six lithostratigraphic units make up the outcrop, consisting of sand, conglomerates and pumice material (figure 4.8). This site is $160 \mathrm{~m}$ from the $6.5 \mathrm{ka}$ sea cliff.

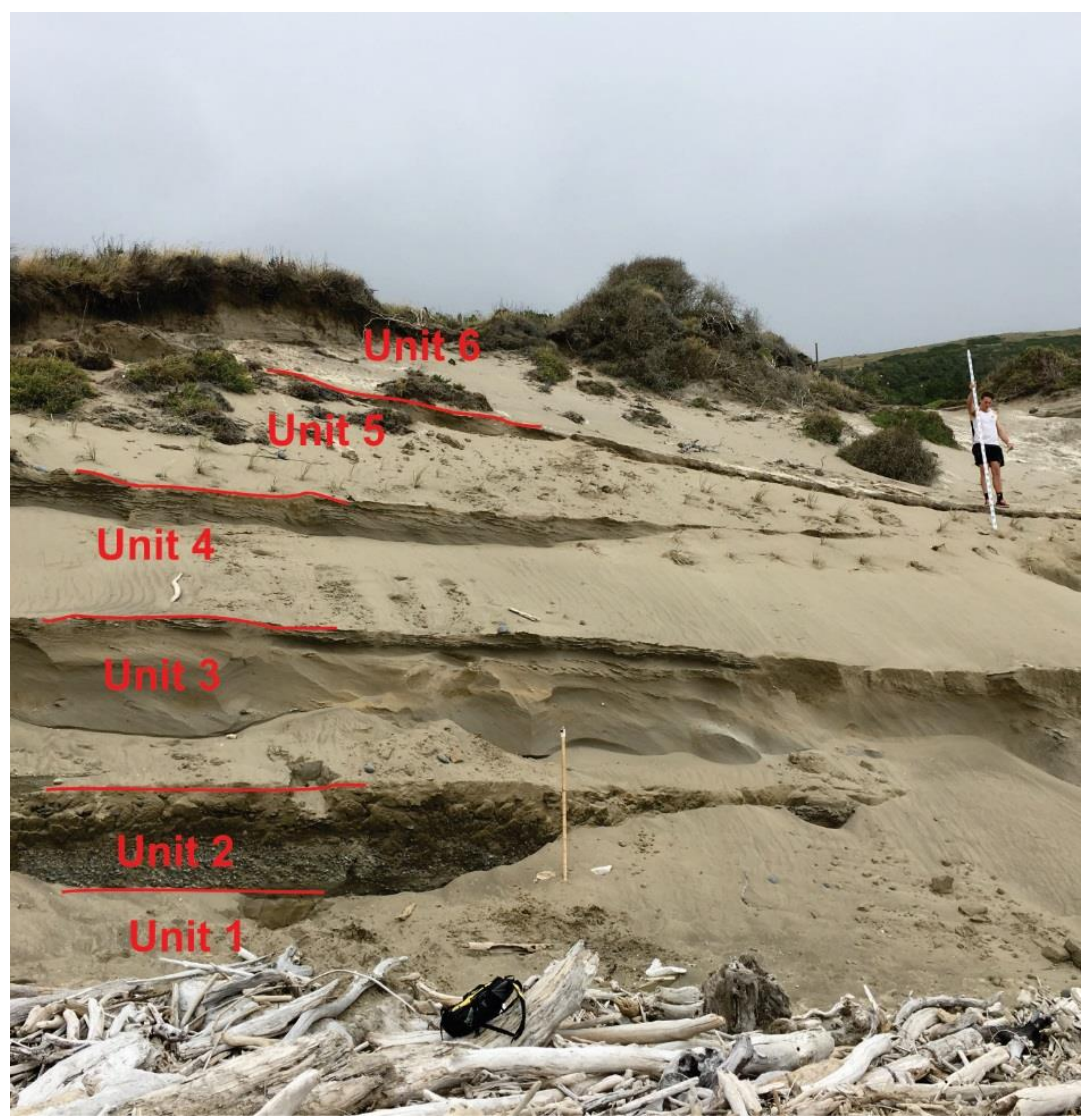

Figure 4.7: Annotated photo of the North Fisherman's Table (NFT) outcrop. Units and their boundaries are shown. Jacobs staff in foreground is $1.5 \mathrm{~m}$ high, author in background holds a $3 \mathrm{~m}$ ruler.

The lowest unit of the outcrop is a fine brown sand with horizontal laminations (unit 1), the basal contact of this unit was not observed. This basal sand unit has a sharp wavy upper contact, separating it from the conglomerate at $0.55 \mathrm{~m}$. Clasts in this conglomerate (unit 2) are brown and grey Torlesse sandstone pebbles up to $10 \mathrm{~cm}$ in size. The roundness of the clasts ranges from sub-angular to rounded. The matrix of this unit is a poorly-sorted brown sand. The conglomerate is dominantly a matrix supported unit with some clast supported parts. This conglomerate is well-bedded with laterally continuous beds of varying thicknesses. Beds vary from clast supported deposits to thin beds of individual pebbles, as well as matrix supported sand beds and infilled trough structures. 


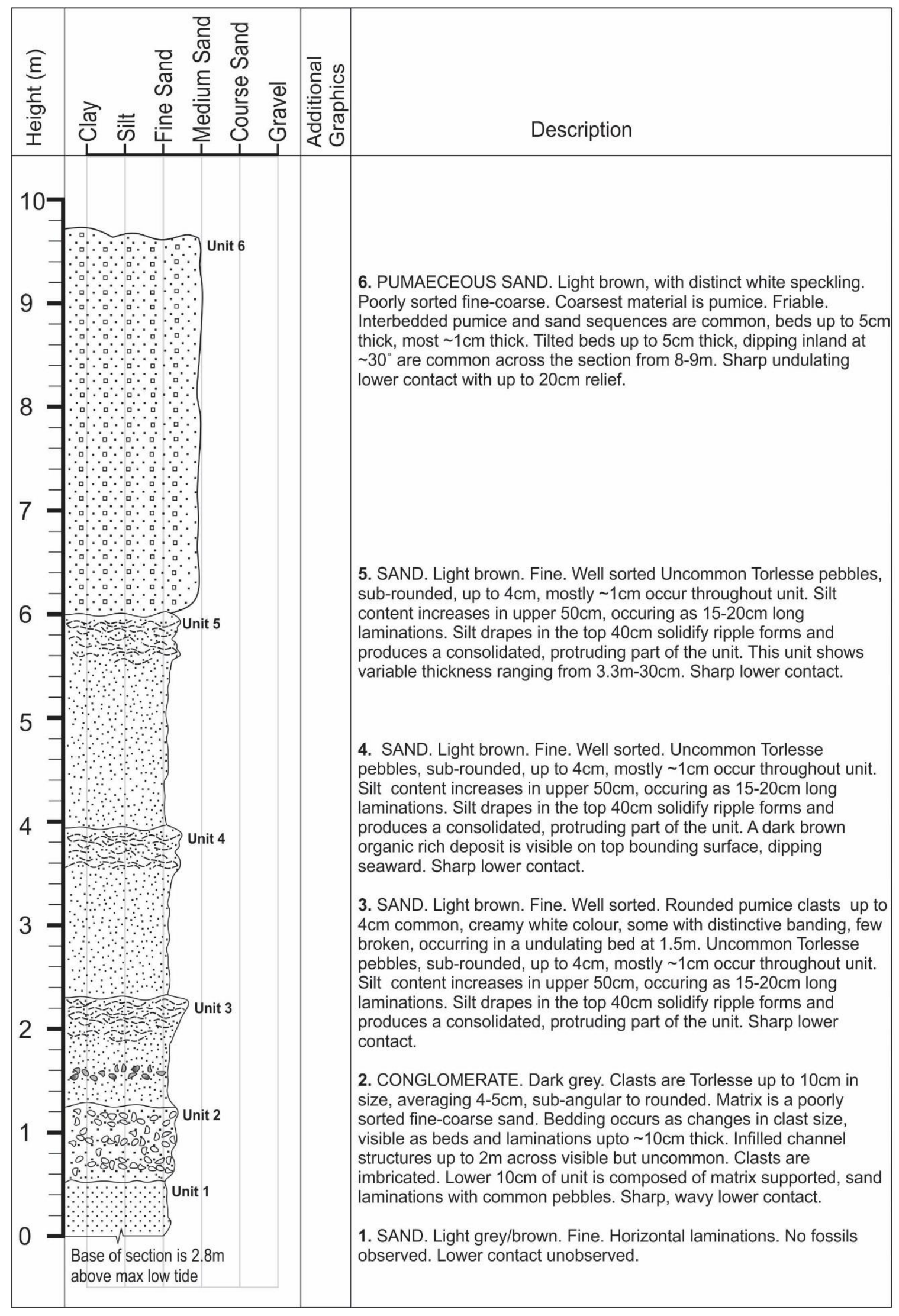

Figure 4.8: The measured section for the North Fisherman's Table (NFT) outcrop. The outcrop shows 6 units consisting of sand, conglomerate and pumaeceous units. A key to the symbols is provided in figure 4.2. 
Overlying the conglomerate are three repeated units of sand (units $3,4 \& 5$ ). These units consist of a fine, well-sorted sand. The top $50 \mathrm{~cm}$ of each of these units shows an increase in silt content, becoming a brittle mix of silt and sand laminations in the form of truncating sequences of ripples. The lowest unit has an undulating $\sim 5 \mathrm{~cm}$ thick bed of pumice pebbles up to $4 \mathrm{~cm}$ in size. The colour of the pumice pebbles is creamy white, with distinctive grey banding on some of the pebbles. Uncommon pumice pebbles are found through all three units. The upper bounding surface of the middle sand unit is marked with a $10 \mathrm{~cm}$ dark brown organic-rich staining of the silty-sand capping unit. The upper silty-sand part is a hard bluff former in outcrop. All units show a sharp upper and lower contact.

Unit 6 is a nearly four metre thick light brown fine-sand, with very common pumice sand. The coarse pumice sand is an off-white cream colour. The bedding of this unit is variable with the base of the unit appearing massive with pumice and sand evenly combined. Between 8 and $9 \mathrm{~m}$ well-bedded deposits are common occurring as repetitively bedded deposits dipping $30^{\circ}$ to the east. 


\subsection{Wainui Stream Cores}

Two cores, WS1 and WS3, were taken adjacent to the beach near Wainui Stream

(figure 4.9), collected at 2.5 and $2.3 \mathrm{~m}$ above sea level respectively. This location is within Queen Elizabeth Park, north of the town of Paekakariki, $1 \mathrm{~km}$ from the $6.5 \mathrm{ka}$ sea cliff. Both cores contain radiocarbon dates, and WS3 contains 4 OSL dates, allowing for age control and sedimentation at the core sites.

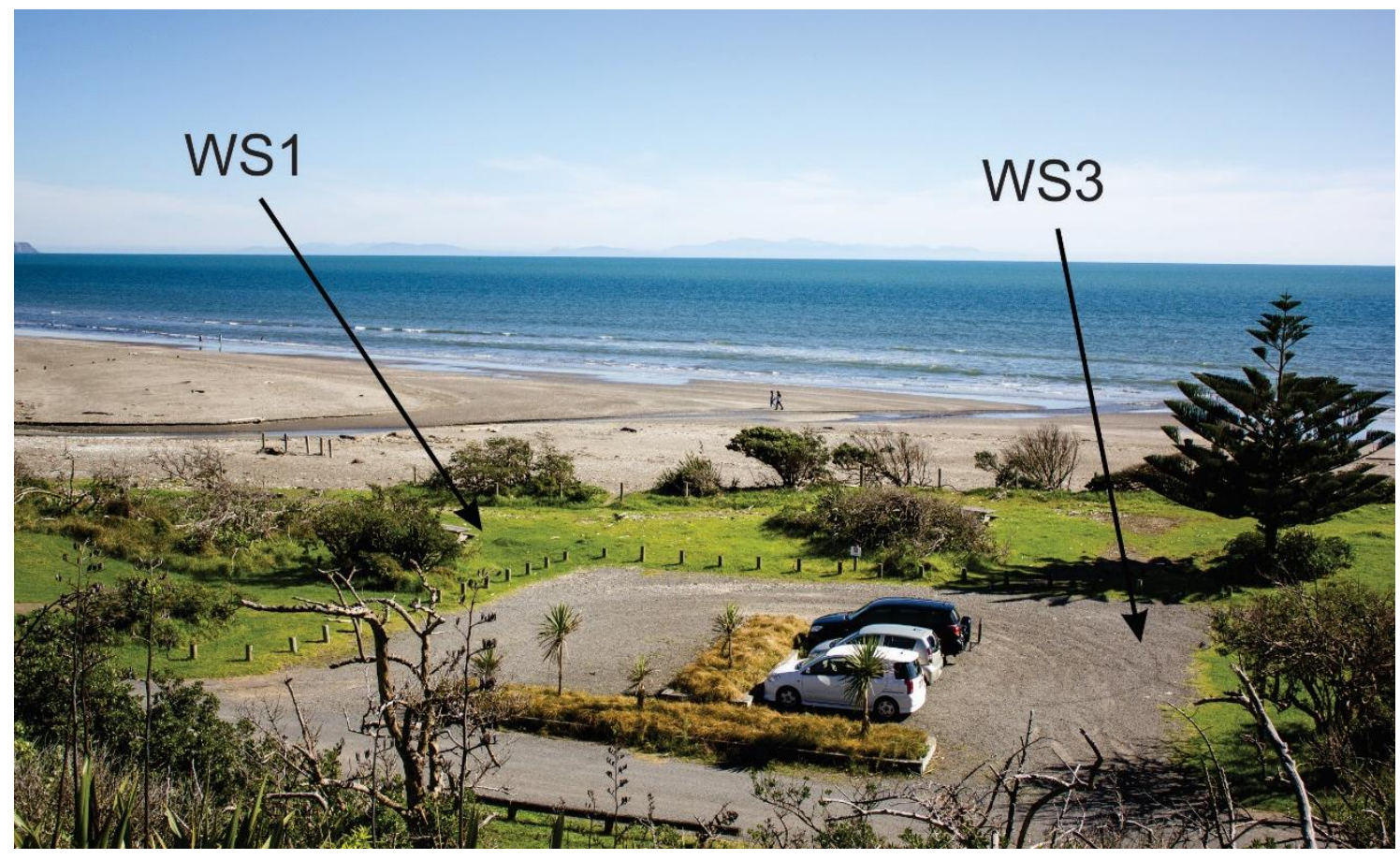

Figure 4.9: Looking southwest across the Wainui Stream mouth (left). The locations of the WS1 and WS3 cores is illustrated. 


\subsubsection{WS1}

This is a $2.2 \mathrm{~m}$ long sediment core (figure 4.10 ) taken from near the mouth of the Wainui Stream. The dominant lithology of this core is sand, with minor shellbeds and a bed of wood fibres. This core was taken using a hand auger and described on site. No grainsize analysis was performed on this core. An uncertainty of $\pm 5 \mathrm{~cm}$ has been given to the depths of this core due to its collection method.

\subsubsection{Description}

The top unit in this core is a brown, fine-grained sand, moderately-sorted (unit 1). This unit has two distinct shell beds composed of whole and broken Paphies subtriangulata and other unidentifiable bivalves. All valves are disarticulated, and the condition of broken pieces range from rounded to angular. The thickest shellbed occurs between 0.3-0.5 (unit 2), with a matrix of coarse sand and Torlesse sandstone granules. The underlying sand unit (unit 3) is a brown fine-sand with rare whole Paphies subtriangulata shells and common shell hash. The middle shellbed occurs at $1.4-1.5 \mathrm{~m}$ (unit 4) and is composed of the same fossils and matrix as the previous shellbed. Unit 5 is a sand similar to the previous two sand units with a single layer of intact Paphies subtriangulata valves marking the base of the unit.

A dark brown, organic-rich sandy layer (unit 6) underlies the single layer of Paphies subtriangulata shells. This unit is located at the depth of $1.65-1.91 \mathrm{~m}$. It is a dark brown, poorly-sorted single bed of short $(<15 \mathrm{~mm})$ wood pieces amongst organic mud, sand and Torlesse sandstone pebbles up to $20 \mathrm{~mm}$, with occasional pumice pebbles. A radiocarbon date on wood pieces from within this unit at $1.7 \mathrm{~m}$, returned a radiocarbon age of $2330 \pm 30$ calBP (Hogg et al., 2013). A sharp lower contact separates the organic deposit from the basal unit.

The lowest unit (unit 7) in this core is a brown fine-medium sandstone. Fossils in this unit are limited to unidentifiable pieces of shell hash. The WS1 core ends at $2.2 \mathrm{~m}$ deep. 


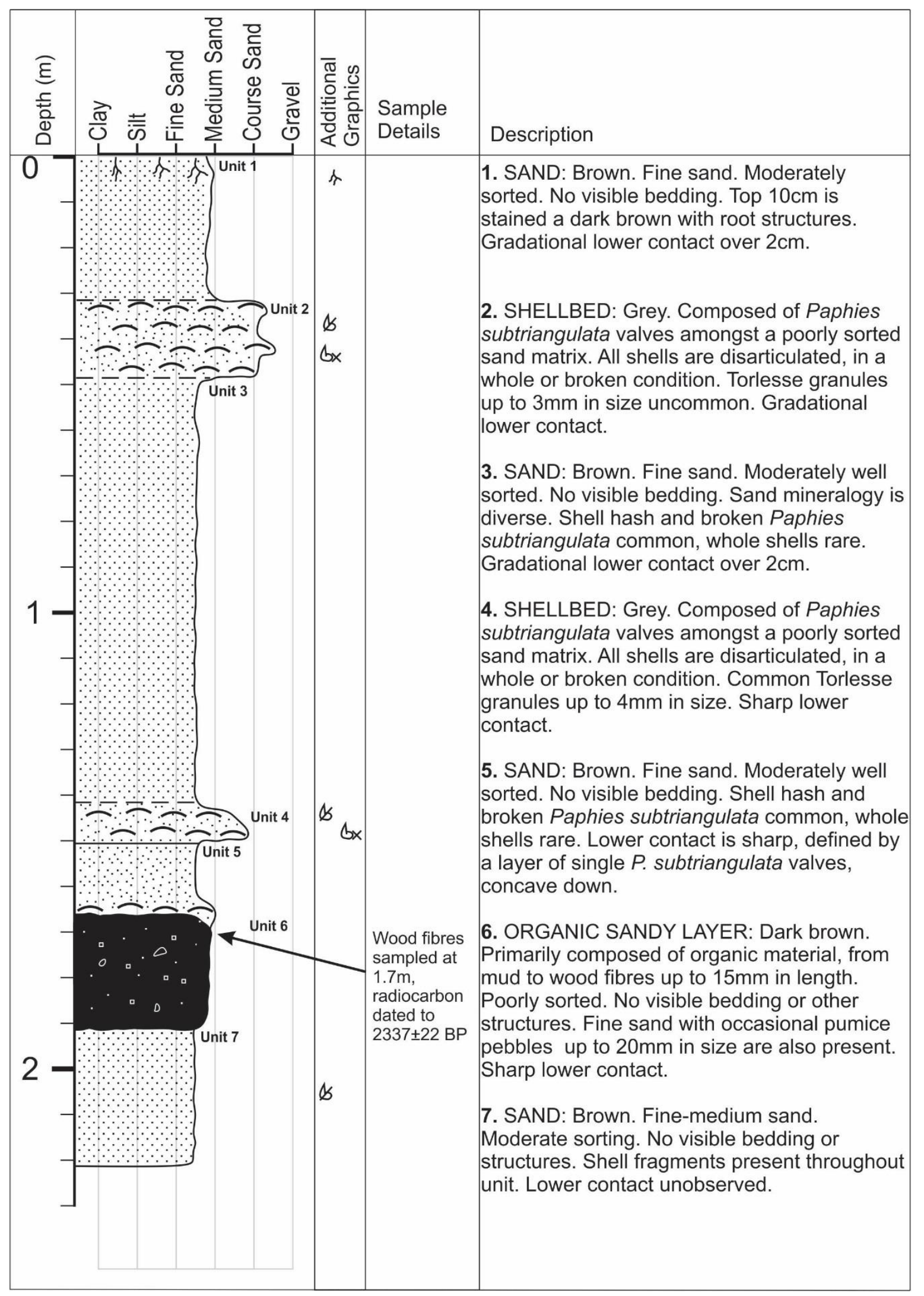

Figure 4.10: The WS1 core is a $2.2 \mathrm{~m}$ sediment core taken from by the Wainui Stream

mouth. Use the key in figure 4.2 to interpret the symbols. 


\subsubsection{WS3}

The analysis of this $29 \mathrm{~m}$ core consisted of description along its length as well as sampling for grainsize and dating (figure 4.11). Four samples were taken for luminescence dating in addition to a single radiocarbon date.

\subsubsection{Description}

The top $80 \mathrm{~cm}$ of this core was not recovered. The upper unit is a $60 \mathrm{~cm}$ light brown/grey conglomerate, composed of poorly-sorted, angular Torlesse sandstone clasts in a grey mud and fine-sand matrix (unit 1)(figure 4.12). The conglomerate is clast supported with no bedding visible or any preferred orientation to the clasts. The lower contact is sharp.

From 1.4-3.3m is a brown fine-medium sand (unit 2). Quartz, orthoclase, amphiboles, feldspars and fragments of lithic material were identified as some of the grains in this unit. The sand is poorly-sorted with common Torlesse sandstone pebbles and granules. This unit contains whole and broken bivalve fossils of Paphies subtriangulata and Dosinia sp., the shells are scattered, except for a concentrated shellbed at $2.8 \mathrm{~m}$, within this shellbed a single $15 \mathrm{~mm}$ Evechinus chloroticus spine was found. The lower contact for this unit is gradational over $3 \mathrm{~cm}$.

From 3.3-9m the dominant lithology is a brown fine-sand (units 3, 5, 7 \& 9). It is wellbedded containing thin organic deposits, shells and pebbles with sorting that ranges from poor to moderate. At 4.1-4.3 is a dark brown organic unit (unit4) composed of short organic fibres up to $5 \mathrm{~mm}$ in length, fining up into an organic mud (figure 4.13). Between $4.77-4.79 \mathrm{~m}$ is a package of finely laminated brown organic mud and brown sand with lamina 5-10mm thick (unit 6). Another laminated sequence of light-grey silty-sand and brown fine-sand occurs at $6.85-7 \mathrm{~m}$, with laminations $6-10 \mathrm{~mm}$ thick (unit 8). Well-rounded Torlesse sandstone clasts are common in this part of the core, occurring up to $2 \mathrm{~cm}$ in size, are found scattered throughout as well as in beds at 5.11$5.14 \mathrm{~m}, 6.5-6.6 \mathrm{~m}$ and $8.85-9 \mathrm{~m}$. 


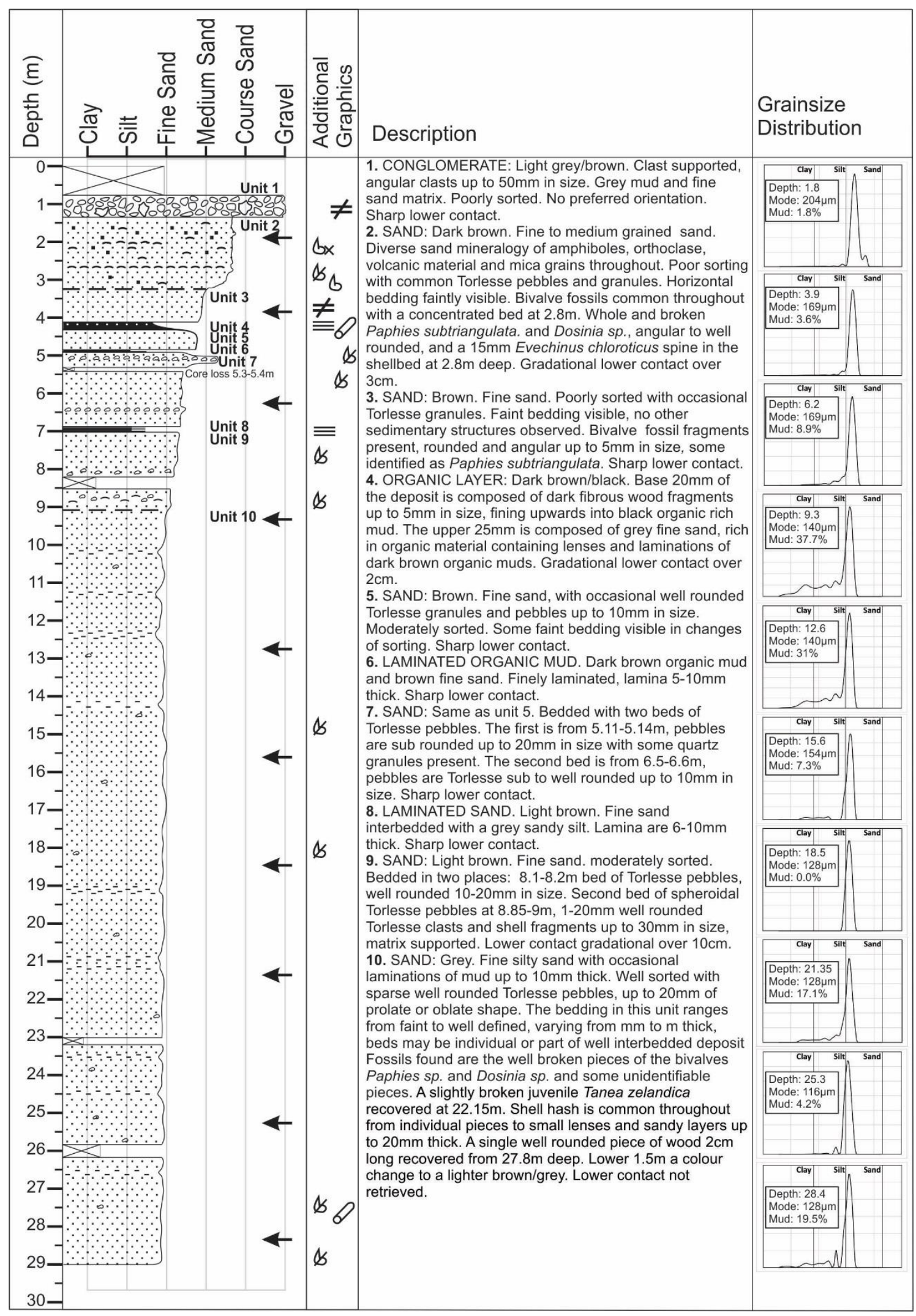

Figure 4.11: The $29 \mathrm{~m}$ WS3 core log. The graphic representation of the core, description and grainsize distribution are presented. The values in the grainsize graphs are sample depth, modal grainsize and the mud percent of the sample. A key to the symbols is provided in figure 4.2 . 


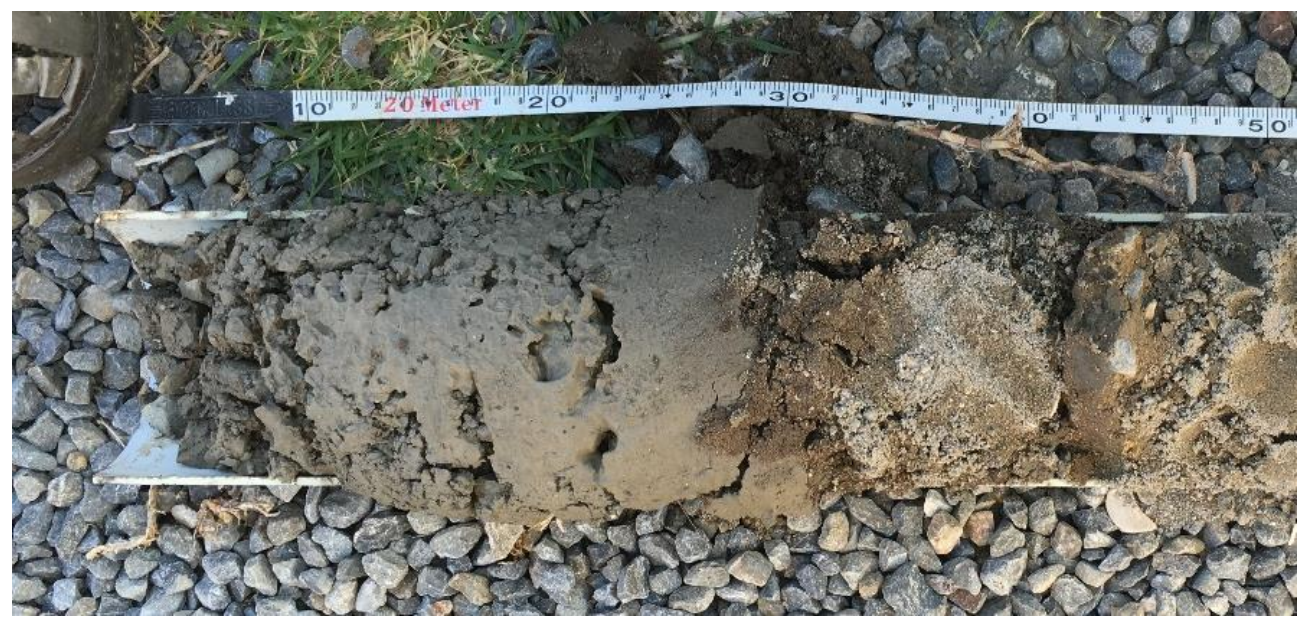

Figure 4.12: The poorly-sorted unit 1 conglomerate from the WS3 core, on the carpark surface the core was drilled through.

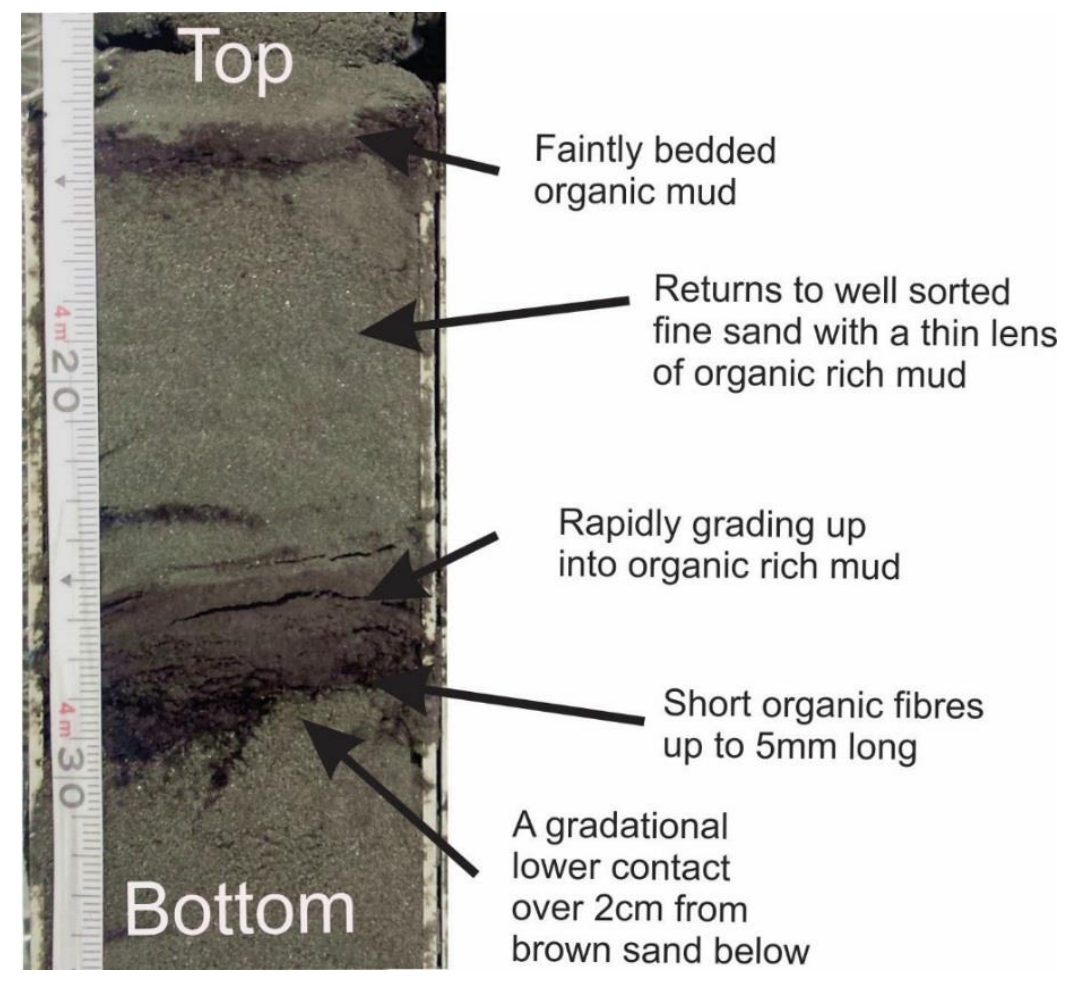

Figure 4.13: A sequence of organic material from unit 4 in the WS3 core. The lowest part of the sequence is a deposit of short organic wood fibres and grades up to a dark organic mud before returning to brown fine-sand with thin lenses and faint organic beds.

The basal $20 \mathrm{~m}$ of this core is a grey, very-fine-sand, with variable sorting from poor to well-sorted (unit 10). Thin beds of grey mud up to $10 \mathrm{~mm}$ thick is the only bedding visible in this unit and occur frequently through the unit with an irregular distribution. Fossils in this unit are broken valves of the bivalves Paphies sp. and Dosinia sp. and a single juvenile Tanea zelandica with minor shell breakage. Other features of this unit 
are occasional shell hash lenses up to $20 \mathrm{~mm}$ thick. Sparse well-rounded Torlesse sandstone pebbles up to $2 \mathrm{~cm}$ in size were found through this unit. The lower $1.5 \mathrm{~m}$ show a gradual colour change, to a light brown sand.

Overall this core shows a coarsening from muddy-sand (unit 10) to a poorly-sorted fine-sand with granules and pebbles (unit 2), overlain by a conglomerate (unit 1).

\subsubsection{Grainsize}

Analysis of the grainsize samples from the core was performed on 34 samples taken through the length of the WS3 core (appendix 1; pg. 138). The sampling frequency varies from every $20 \mathrm{~cm}$, to every $1 \mathrm{~m}$, dictated by visual lithology changes. The upper $9 m$ were sampled at a greater frequency than the basal $20 m$ of grey sand.

The modal grainsize of the samples varies from a coarse silt to a medium sand, with the majority being fine or very fine-sand. Grainsize distribution demonstrates a down core fining $r^{2}$ value of 0.46 . The sample taken from $2.9 \mathrm{~m}$ shows a modal grainsize of $356.5 \mu \mathrm{m}$ (figure 4.14) and is a deviation from this. The finest samples have a modal grainsize of $116 \mu \mathrm{m}$, found in the lower $10 \mathrm{~m}$ of the core.

The percentage of mud in the samples taken from through this core varies from $0 \%$ to nearly $50 \%$. The trend of this data down core is a general increase of percent mud, with an $r^{2}$ value of 0.21 , however this is not a consistent gradient (figure 4.14). The samples collected from unit 10 confirm the observation of a finer unit.

The sorting (standard deviation) (Folk and Ward, 1957) of the samples vary from wellsorted to very poorly-sorted (figure 4.14)(appendix 1; pg. 138). The down core trend shows a decrease in the degree of sorting towards the bottom of the core with an $r^{2}$ value of 0.30 . 


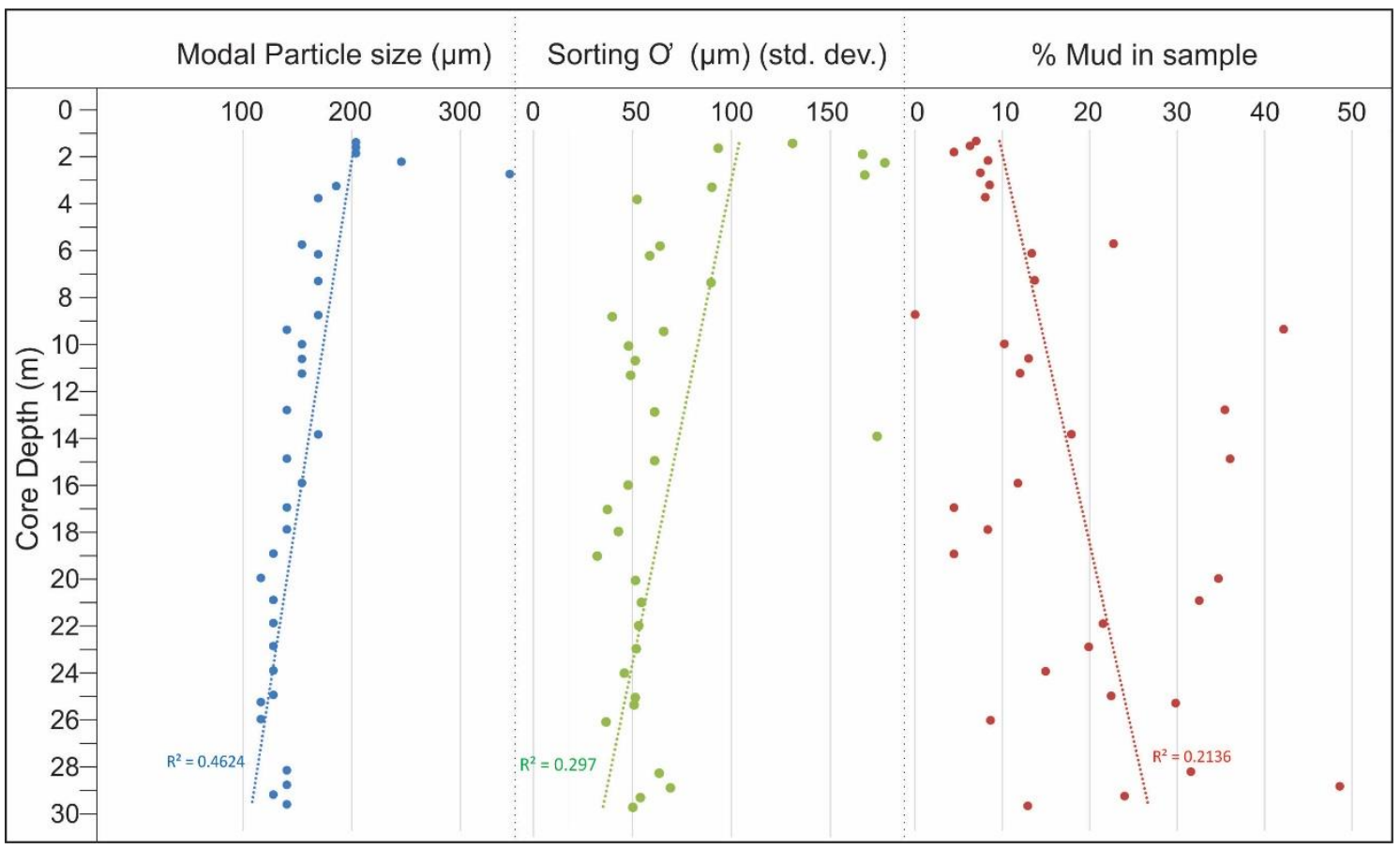

Figure 4.14: This graph demonstrates the modal grainsize and \%mud for the WS3 core.

The modal values show a gradual change to finer material down core, while the \%mud shows elevated values becoming more common down the core. The sorting (standard deviation) of samples taken through the WS3 core, show that the lower samples are more poorly sorted (evident in the increase percent mud).

\subsubsection{Age Control}

The age control of this core consists of four optically stimulated luminescence dates (OSL) and a single radiocarbon (appendix 3, pg. 160). Radiocarbon dating was undertaken on a $2 \mathrm{~cm}$ piece of wood from $27.8 \mathrm{~m}$ deep, returning a radiocarbon age of $7717 \pm 99$ years BP. Sand was sampled in four places for OSL dating at the depths of $17.69 \mathrm{~m}, 18.15 \mathrm{~m}, 27.5 \mathrm{~m}$ and $27.94 \mathrm{~m}$. The analysis of these giving ages of $5270 \pm 360$ calBP , $5430 \pm 370$ calBP, $6030 \pm 410$ calBP and $6060 \pm 420$ calBP respectively. 


\subsection{Pickle Pot Dune Face}

This is a measured section of a westward facing dune scarp on the shoreline near the Pickle Pot picnic area, $410 \mathrm{~m}$ north of the Wainui Stream (figure 4.15). The section (figure 4.16) was measured in early June 2016 following a large ocean storm that scarped the dunes. Four lithostratigraphic units are recognised in this outcrop. The dominant lithology is a sand with a high percentage of pumice clasts and sand. This section is interpreted with the Wainui Stream cores as the Wainui Coastal Sites.

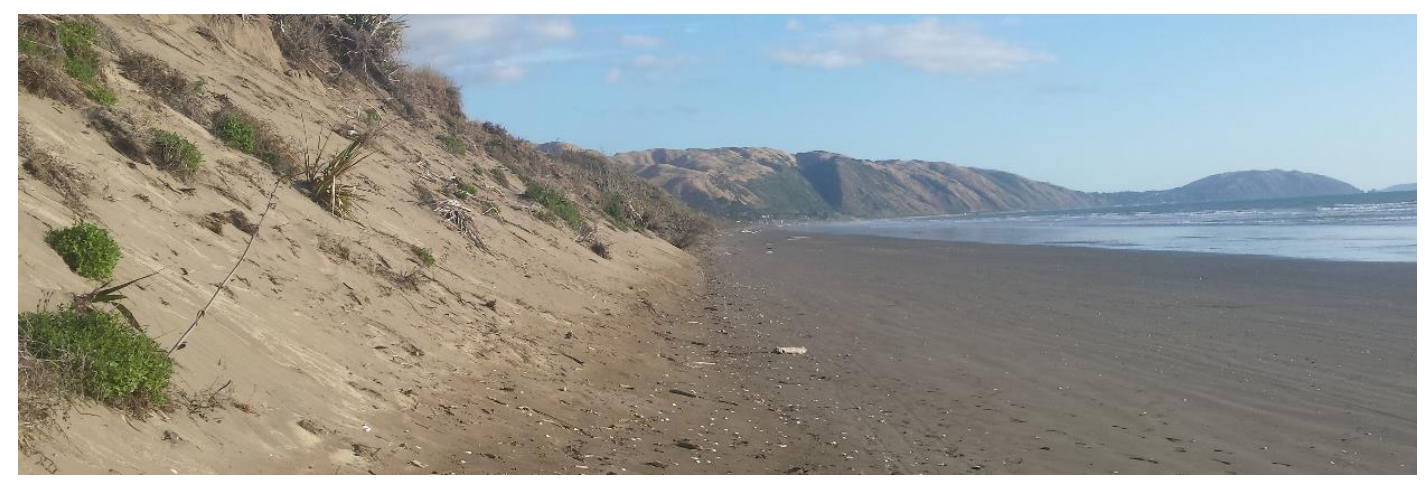

Figure 4.15: Looking south towards Paekakariki from the Pickle Pot outcrop. The dune scarp on the left demonstrates the erosional processes operating on this part of the coast.

\subsubsection{Description}

The basal unit in this outcrop is a light brown, fine-sand that is well-sorted (unit 1). The lowest occurrence of pumice is $20 \mathrm{~cm}$ from the base of the section in the form of 2 beds of pumice clasts, above this the percentage of pumice decreases along with the mean size of volcanic material. Clasts range in size from $20 \mathrm{~cm}$ to $2-3 \mathrm{~mm}$, these deposits are not restricted to this outcrop and are laterally continuous across the dune scarp.

Above the volcanic material is a $40 \mathrm{~cm}$ package of well-bedded, southward dipping beds, composed of sand, Torlesse sandstone granules, and pumice grains up to $3 \mathrm{~mm}$ in size. Beds are no more than $4 \mathrm{~cm}$ thick and dip at $30^{\circ}$.

The top unit is a friable light brown pumaeceous sandstone with a gradational contact into the underlying unit. The pumice is $2-3 \mathrm{~mm}$ in size and evenly distributed amongst the sand at the base, with a slight decline in content towards the top of the section. Some root structures and other organic fibres are seen throughout. 


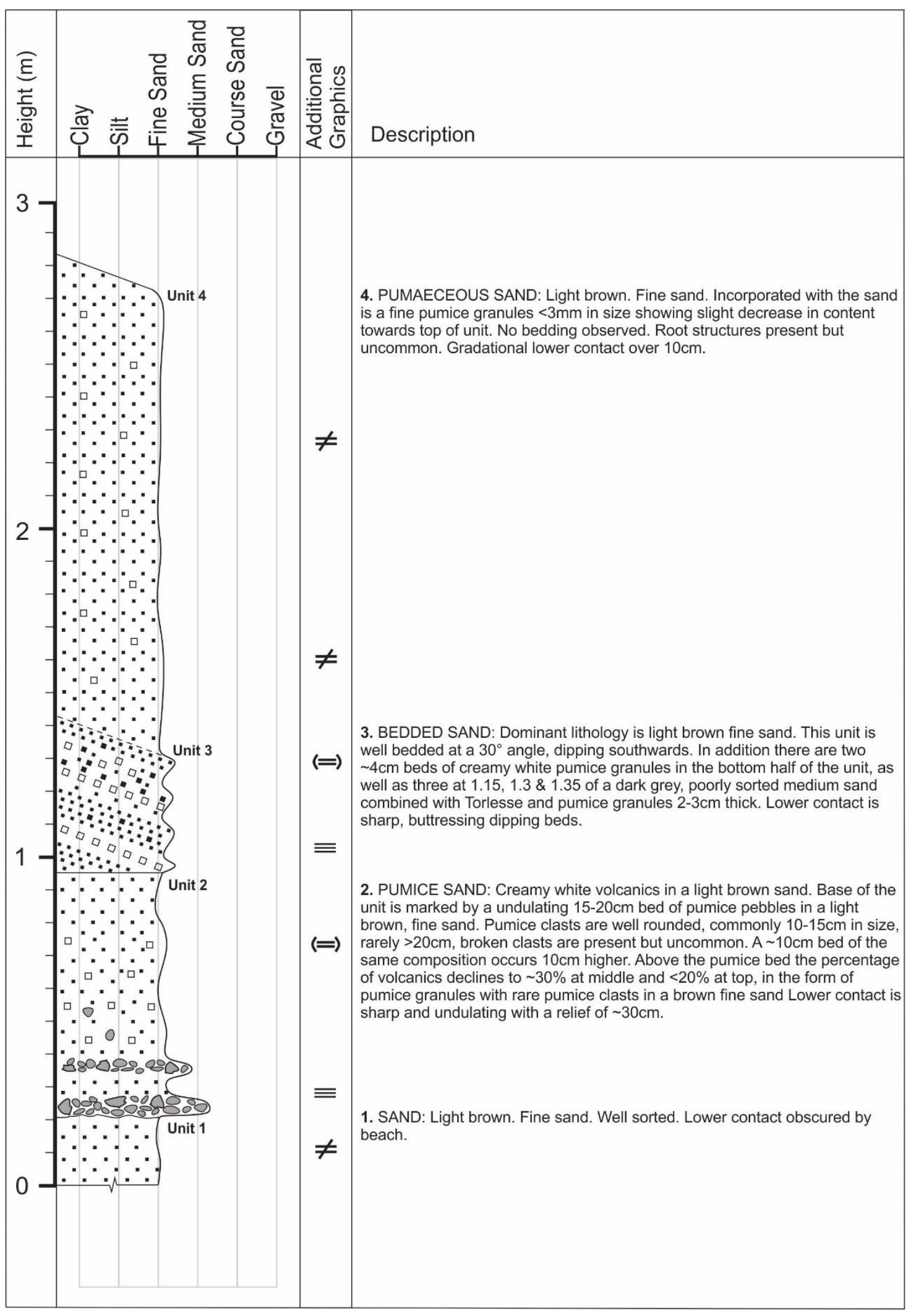

Figure 4.16. The measured section for the Pickle Pot outcrop. Four units of sand and pumice material are recognised. A key to the symbols is provided in figure 4.2. 


\subsection{Wharemauku Cores}

These four cores were provided to this study by the geotechnical company Aurecon.

The cores were taken as part of a subsurface geotechnical investigation at Kāpiti Airport. Three of the cores, $A B 1, A B 2 \& A B 4$, were drilled closely together through part of the tar seal taxiway, while the AB3 core was collected $500 \mathrm{~m}$ south of the grouping, drilled through the grass surface of the airport (figure 4.17). The four cores are similar in appearance and composition, being primarily composed of fine-sand.

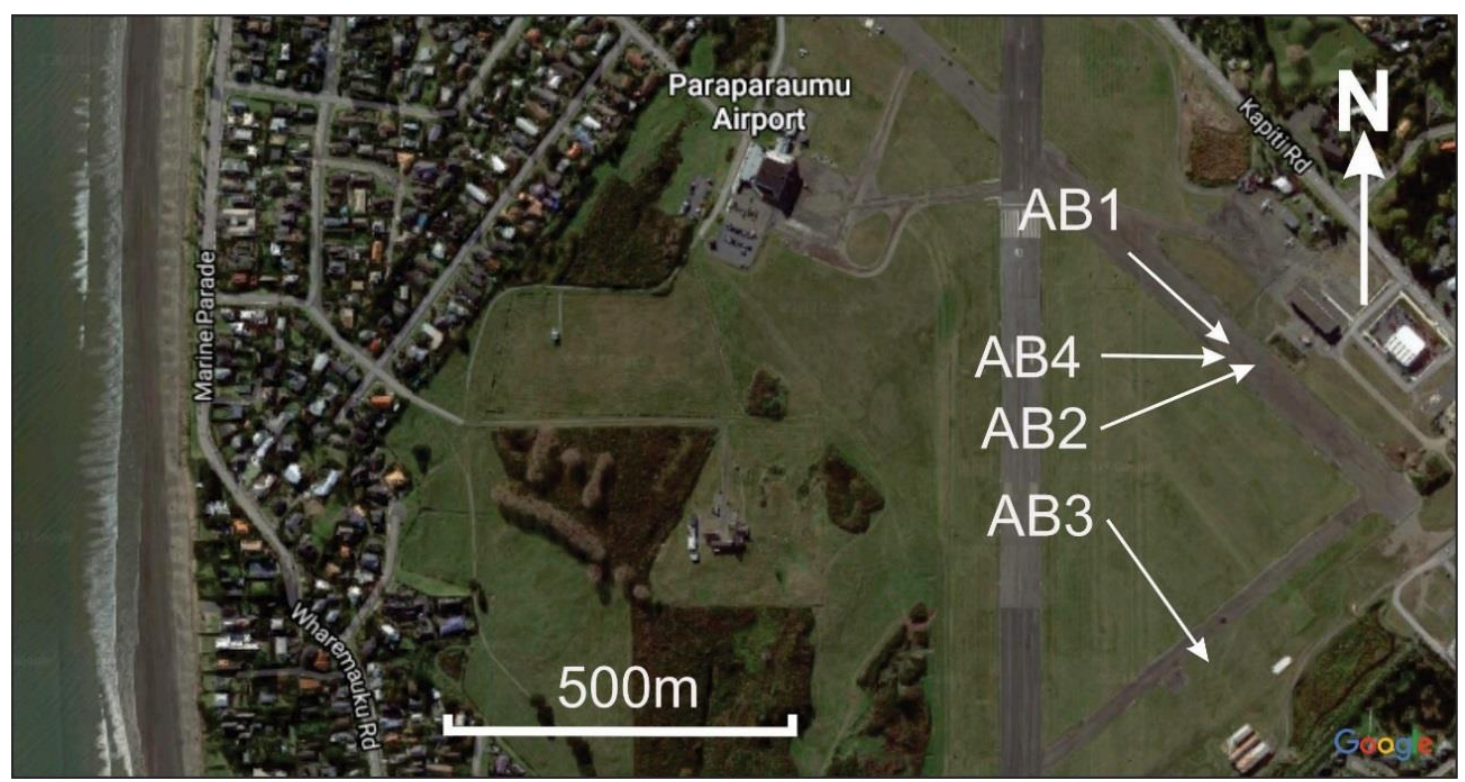

Figure 4.17: The locations of the Wharemauku cores collected at Kāpiti

(Paraparaumu) Airport. Base image taken from maps.google.com. The context of this map is shown on figure 4.1. 


\subsubsection{AB1}

The AB1 core consists of 11 individual lithostratigraphic units (figure 4.18), consisting of conglomerates and sands with an organic-rich mud concentrated at $5 \mathrm{~m}$ depth. The core has two sections of core loss 6.2-6.5m and 9-10.5m.

\subsubsection{Description}

The top 3.4m of this core consists of poorly-sorted conglomerate (units $1,3 \& 5$ ) interbedded with units of light brown sand (units $2 \& 6$ ). The conglomerates consist of angular Torlesse sandstone clasts amongst a brown sandy matrix, with clasts showing no preferred orientation. Scattered pieces of wood and root fibres are present. The sand contains angular Torlesse pebbles and broken pieces of wood, short thin root structures are uncommon.

Below $3.4 \mathrm{~m}$ is a deposit of light brown fine-sand (unit 6). The top $40 \mathrm{~mm}$ of this unit are stained a dark brown organic colour, while the rest of the unit is massive. An increasing amount of organic content marks the gradational contact into the organic-rich sand below. Between 4.5-5.6m, the poorly-sorted fine-sand of this unit grades into an organic mud at $4.9 \mathrm{~m}$ before gradually changing to sand at $5.2 \mathrm{~m}$. Root structures and organic fibres are common in this deposit with rare Torlesse sandstone pebbles up to $10 \mathrm{~mm}$ also present. The lower contact for this unit is gradational over $50 \mathrm{~mm}$.

Below the organic-rich deposit is a light-grey laminated sand, $30 \mathrm{~cm}$ thick. A light-grey fine-medium sand in laminations up to $8 \mathrm{~mm}$ thick, is laminated with a silty fine-sand of a darker grey up to $6 \mathrm{~mm}$ thick. This unit grades down into grey fine-sand. Only $20 \mathrm{~cm}$ of this well-sorted unit was recovered due to a core loss from $6.1-6.5 \mathrm{~m}$.

Below the core loss is a $45 \mathrm{~cm}$ thick deposit of a grey sandy conglomerate. The clasts in this unit are sub rounded clasts of Torlesse sandstone granules and pebbles up to $50 \mathrm{~mm}$ in size. The rest of this matrix supported unit is a grey medium sand with some sparse shell hash. The conglomerate grades into the cores basal unit over $20 \mathrm{~mm}$.

The basal unit of this core is a brown fine-sand, beginning at $6.5 \mathrm{~m}$ it extends to $11.5 \mathrm{~m}$. This unit is initially poorly-sorted improving with depth. Some coarse grains and Torlesse sandstone pebbles up to $10 \mathrm{~mm}$ scattered through the unit. Some faint bedding and laminations are visible through this unit, in addition to some unidentifiable shell hash. 


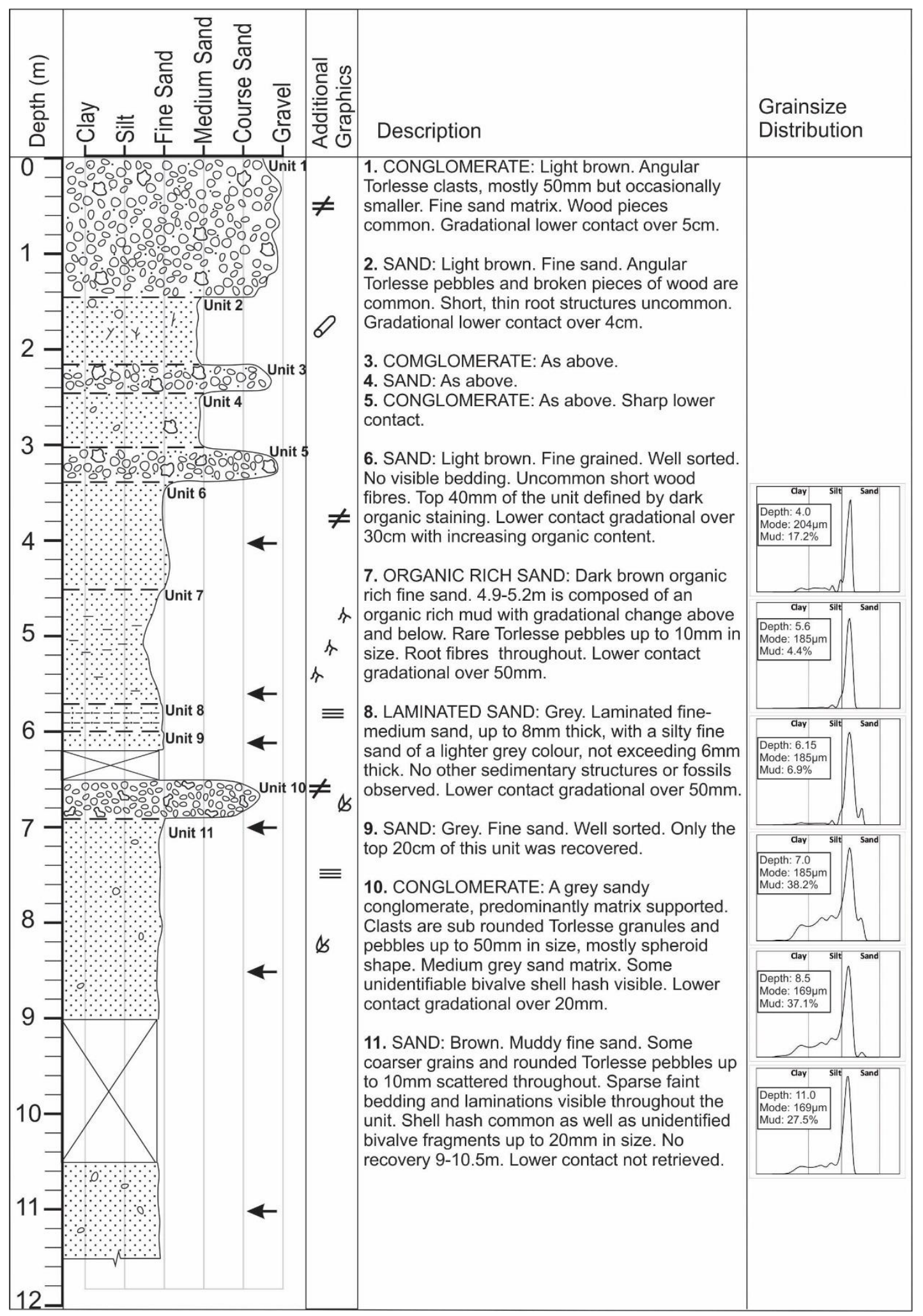

Figure 4.18: Core log of the AB1 core taken from Kāpiti Airport. The values in the grainsize graphs are sample depth, modal grainsize and the mud percent of the sample. A key to the symbols is provided in figure 4.2. 


\subsubsection{Grainsize and point counting}

Grainsize analysis was performed on seven samples from the AB1 core (appendix 1; pg. 144). All samples analysed for grainsize from this core had a mean distribution of finesand, with a down core fining trend producing an $r^{2}$ value of 0.42 . The sorting of the majority of the samples was poor with only the sample from $5.6 \mathrm{~m}$ returned as wellsorted. The $r^{2}$ value of the sorting with depth is 0.27 , indicating there is a slight trend of decreased sorting down the core.

The distribution of grainsize for most samples displayed a mud tail, this mud percent was highest in samples from unit 11, supporting the observation of this as a muddysand. The mud percent was significantly less for the samples from the middle of the core compared to the basal unit, while the uppermost sample from $4 \mathrm{~m}$, had a mud value of $17.2 \%$.

Point counting was performed on 5 samples from this core to determine roundness and variations in the lithology of grains (appendix 2; pg. 157 \& 158). Roundness showed no trend along the cores length, with roundness measurements for the samples recorded between 3.28-3.57. The lithology percentage for samples was dominated by the lithic material followed by quartz, other grains and finally feldspar. The other category of sample from $7.6 \mathrm{~m}$ was dominated by volcanic glass and heavy minerals. 


\subsubsection{AB2}

The AB2 core contains 12 lithostratigraphic units (figure 4.19), of conglomerates, sand and organic units.

\subsubsection{Description}

The upper $3.4 \mathrm{~m}$ of this core consists of interbedded sands and conglomerates. The conglomerates (units 1, $3 \& 5$ ) are light brown and poorly-sorted. The clasts are angular brown Torlesse sandstone, commonly $50 \mathrm{~mm}$ in size with a few smaller pebbles. The matrix is a brown fine-sand with a minor grey mud component. The clasts of these conglomerates show no preferred orientation within the unit, and scattered pieces of wood and root fibres are visible throughout. The sands (units 2, 4 \& 6) are light brown fine-sand, with common angular Torlesse sandstone clasts. The basal contact of the lowest sand unit is gradational over $10 \mathrm{~cm}$

Two sand units compose the middle of this core. The upper one (unit 7) is a brown/grey fine-sand from 3.4-6m. Despite displaying no visible bedding, this unit has a distinct red-brown staining below $4.5 \mathrm{~m}$. A gradational contact separates these sand units at $6 \mathrm{~m}$, the mineralogy of the lower sand (unit 8) shows a diverse composition in hand sample, with an increase in amphiboles, orthoclase, mica and volcanic material visible. The basal contact for this sand is sharp.

A distinctive $15 \mathrm{~mm}$ bed of organic material (unit 9) is visible at $6.5 \mathrm{~m}$. The short wood fibres in the unit are up to $10 \mathrm{~mm}$ long. The remainder of the core is a light brown sand (unit 10 \& 12) with two more of these organic beds within it (unit 11). The sand is wellsorted and contains broken shell pieces and hash. The organic deposits within this sand are the only bedding visible, and are seen at the depth of $8.42 \mathrm{~m}$ and $8.57 \mathrm{~m}$. The lower contact of this sand unit was not recovered

\subsubsection{Grainsize and Point Counting}

Eight samples were taken from this core for grainsize analysis (appendix 1; pg. 146). All samples showed modal values of a fine-sand measured as between $169 \mu \mathrm{m}$ and $203 \mu \mathrm{m}$, evenly distributed through the length of the core. All samples were poorlysorted with distributions skewed towards very fine. In addition to the finely skewed tail, the lower two samples in this core $(7.3$ and $8.3 \mathrm{~m})$ have a small component of medium-coarse material. 
Two samples from this core were mounted for point counting (appendix 2; pg. 157 \& 158). The results for the roundness of the samples 5.2 and 7.3 gave similar results for roundness, with values of 3.29 and 3.23 respectively. Mineralogical composition also showed very similar results with all grain categories measured, falling within $2 \%$ of difference between samples. 


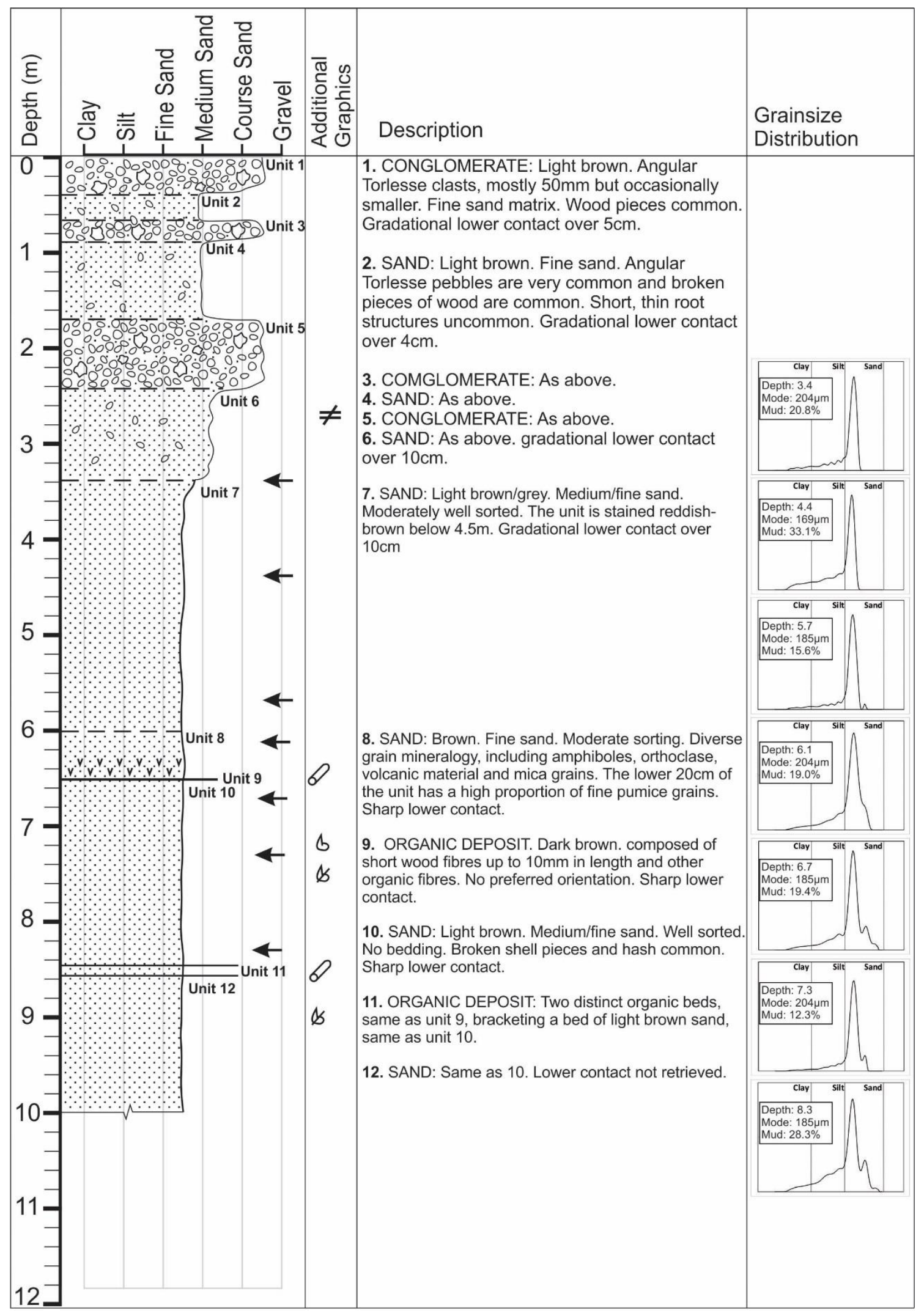

Figure 4.19. Core log of the AB2 core taken from Kāpiti Airport. The values in the

grainsize graphs are sample depth, modal grainsize and the mud percent of the sample.

A key to the symbols is provided in figure 4.2. 


\subsubsection{AB3}

Twelve lithostratigraphic units have been recognised in this core (figure 4.20), it is the longest core from this location. Grainsize samples were taken at fifteen heights through the length of this core.

\subsubsection{Description}

The top unit of the core is $3.2 \mathrm{~m}$ of a brown silty fine-sand, with an inconsistent mottled colour. Two dark beds of organic material, located at $0.6 \mathrm{~m}$ and $1.4 \mathrm{~m}$, are the only bedding visible in this unit. Lower contact is gradational over $3 \mathrm{~cm}$.

The second unit in this core is a light brown fine-sand. This unit has an extensive amount of organic discolouration due to the incorporation of organic mud and roots into the sand. The organic mud is most prevalent at $4-4.2 \mathrm{~m}$. The lower contact is gradational over $1 \mathrm{~m}$.

A brown massive sand unit located from $5.1-6.7 \mathrm{~m}$. The mineralogy of the grains in this unit is diverse, with a greater component of amphiboles and orthoclase as well as very fine pumice grains and mica flakes. A sharp lower contact separates this sand unit from the grey laminated sands below. A light-grey fine-sand, occurring in laminations 4$10 \mathrm{~mm}$ thick is laminated with a dark-grey silty fine-sand, bedded $2-4 \mathrm{~mm}$ thick. Some of the fine-sand laminations in the lower part of this unit are faintly stained orange. The lower contact was not retrieved due to $10 \mathrm{~cm}$ of core loss.

The top of a brown fine-sand occurs at $7.5 \mathrm{~m}$. This unit is moderately-sorted and contains two different beds. The top of the uppermost bed is at $7.8 \mathrm{~m}$, it is a single 2$5 \mathrm{~cm}$ thick shellbed composed of Paphies subtriangulata in broken and whole condition, broken pieces are broken and angular. The lower bed is an undulating $2 \mathrm{~cm}$ thick deposit of dark brown short organic fibres with $4 \mathrm{~cm}$ of relief to the bed. The lower contact for this unit is gradational over $20 \mathrm{~cm}$. 


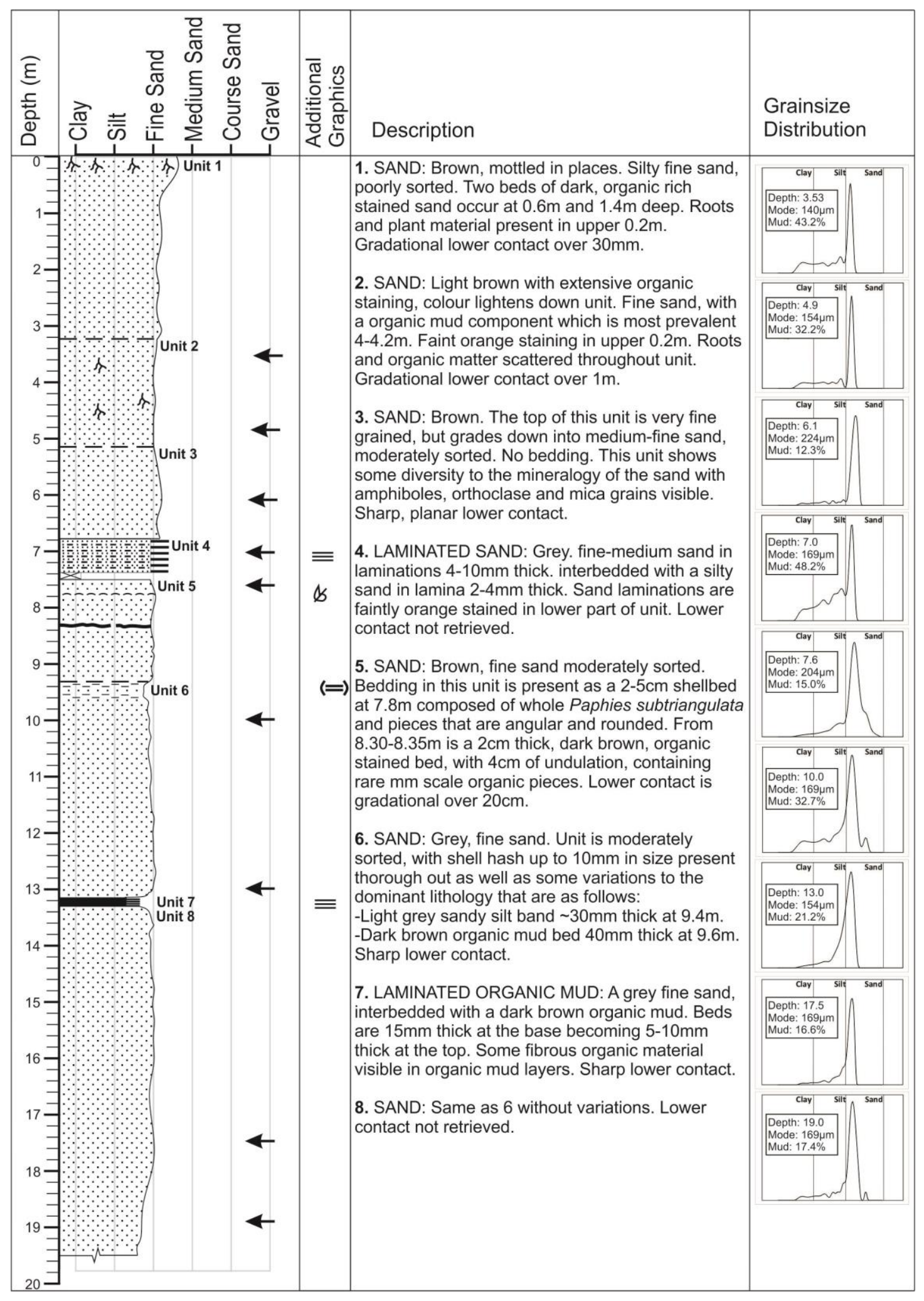

Figure 4.20: Core log of the AB3 core taken from Kāpiti Airport. The values in the grainsize graphs are sample depth, modal grainsize and the mud percent of the sample. A key to the symbols is provided in figure 4.2 . 
The basal unit for this core is a grey fine-sand, it is moderately-sorted with shell hash and pieces up to $10 \mathrm{~mm}$ common throughout the unit. Three bedded sections are the only bedding visible in this unit. The top is a faintly bedded $30 \mathrm{~mm}$ thick silt bed at $9.4 \mathrm{~m}$, the middle is a $40 \mathrm{~mm}$ organic mud deposit. The lowest bedded portion from $13.15-13.25 \mathrm{~m}$ is a sequence of finely laminated dark brown organic mud in the grey sand of the unit. The thickness of laminations in this sequence are $5-10 \mathrm{~mm}$ at the top, thickening to $15 \mathrm{~mm}$ at the base. Core ends at $19.5 \mathrm{~m}$.

\subsubsection{Grainsize}

Sixteen samples were analysed for grainsize distribution from this core (appendix 1 ; pg. 148). All samples had a modal grainsize between $140 \mu \mathrm{m}$ and $224 \mu \mathrm{m}$. The sample from $5.6 \mathrm{~m}$, measured $54.8 \%$ mud content, the only sample to return a \%mud that was greater than $50 \%$, the majority fraction for all other samples was a fine-sand. Values of $32.2-43.2 \%$ for the samples analysed from unit 2 support the observation of an elevated organic mud content in this unit. While the elevated mud $(48.2 \%)$ in the sample collected in the laminated mud unit (unit 4) demonstrates the high content that is observed in these laminations.

The sorting of the samples ranged from moderately well-sorted to very poorly-sorted, with the distribution of the samples all skewed to very fine material. The observation of the moderate sorting in unit 3 is supported by the results of the Gradistat interpretation of this data (Blott and Pye, 2001). The three upper samples of the basal unit $(14.5 \mathrm{~m}, 16 \mathrm{~m} \& 17.5 \mathrm{~m})$ show a moderate sorting, while the lowest sample $(19 \mathrm{~m})$ is poorly-sorted, attributed to a slightly higher mud content than the other three samples. 


\subsubsection{AB4}

Within this core, eight lithostratigraphic units have been recognised, consisting of sand, conglomerates and some organic deposits (figure 4.21). Eight grainsize samples were taken from this core and five samples were point counted for mineralogy and roundness.

\subsubsection{Description}

At the top of this core is a $1.5 \mathrm{~m}$ thick, light brown conglomerate (unit 1 ). This unit is poorly-sorted and composed of angular Torlesse sandstone clasts up to $50 \mathrm{~mm}$ in a matrix of a light brown poorly-sorted sand. A gradational contact marks the transition to the light brown fine-sand below (unit 2). This sand contains angular Torlesse sandstone pebbles and wood fragments. Uncommon short root structures are visible. The base of this sand is marked by a gradational lower contact. A light brown conglomerate (unit 3) of the same appearance as the upper most conglomerate occurs from $2.5-3 m$ depth. The base of this is sharp planar contact.

The top of a light brown sand is seen at $3 \mathrm{~m}$ (unit 4). This unit is well-sorted with some sparse small organic pieces scattered throughout. The lower contact of this unit is gradational over $30 \mathrm{~mm}$. From $6-7.2 \mathrm{~m}$ is a dark brown sand (unit 5). The mineralogy of the grains in this unit is notably diverse with orthoclase, amphiboles, mica grains and fine pumice grains visible. This unit has an orange brown staining visible below $6.5 \mathrm{~m}$ and becoming more recognisable towards the base of the unit. This unit has a sharp lower contact.

Below $7.2 \mathrm{~m}$ a $30 \mathrm{~cm}$ band of brown sand, with a mottled dark brown colour (unit 6). This unit has common organic fibres, some up to $5 \mathrm{~mm}$ in length, showing no preferred orientation. The lower contact for this organic unit is sharp. A brown fine-sand begins at $7.5 \mathrm{~m}$ (unit 7), this unit is well-sorted with a gradational lower contact. The basal unit of this core is a grey fine-sand (unit 8), with two faintly bedded brown organic mud bands, $4-5 \mathrm{~cm}$ thick, visible below $9.7 \mathrm{~m}$ and $10 \mathrm{~m}$ depth. Lower contact of this unit was not retrieved. 


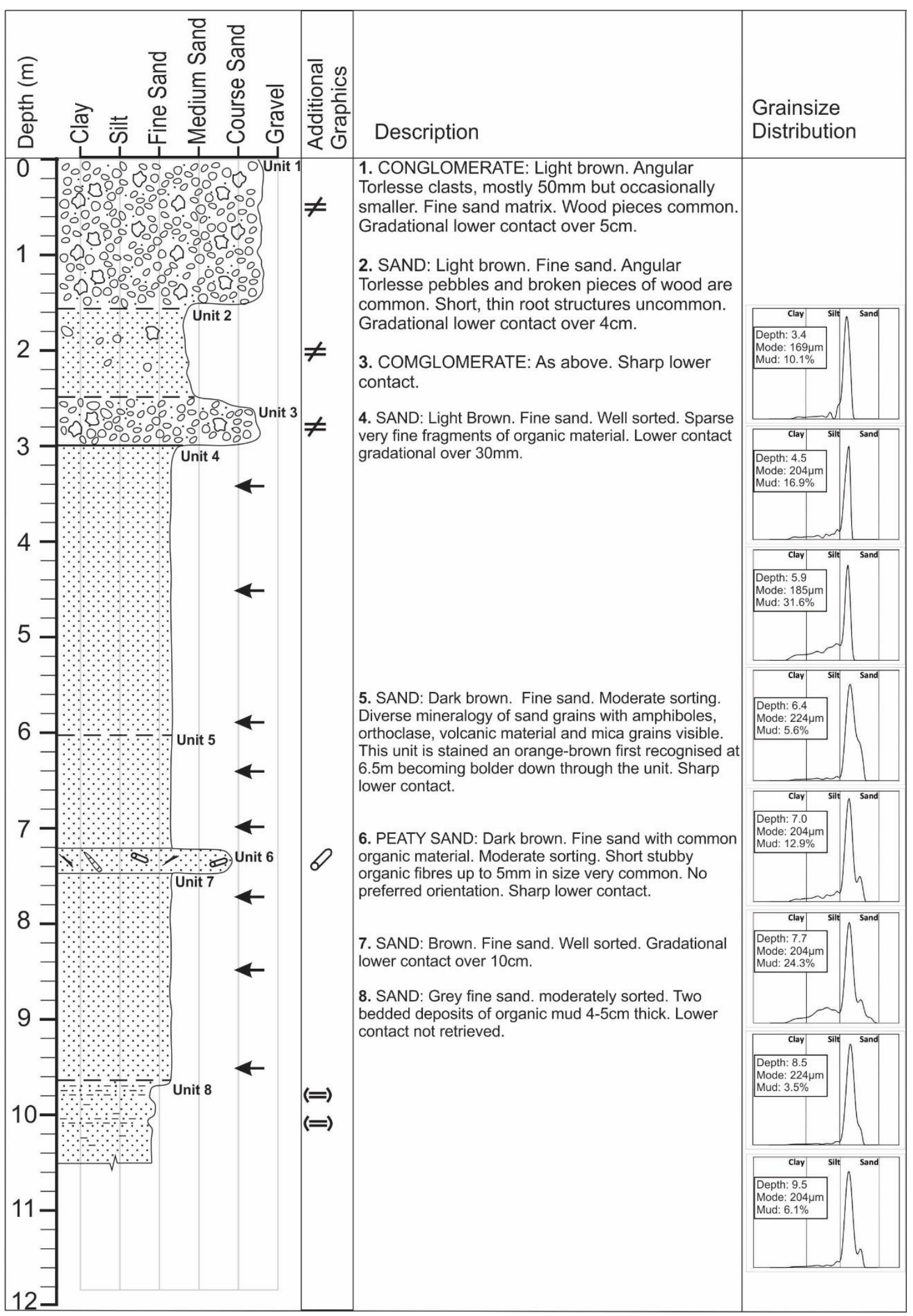

Figure 4.21: Core log of the AB4 core taken from Kāpiti Airport. The values in the grainsize graphs are sample depth, modal grainsize and the mud percent of the sample. A key to the symbols is provided in figure 4.2. 


\subsubsection{Grainsize and Point Counting}

The results of the grainsize analysis for this core, returned all samples as sand, with variations in the sorting and skewness of the distribution (appendix 2; pg. 151). Except for the symmetrical distribution in the $8.5 \mathrm{~m}$ sample, all samples are skewed fine with a mud tail however the size of it varies between samples. The upper 3 samples $(3.4,4.5$ and 5.9) have the finest mean grainsize of the core measuring between 155-121 $\mathrm{m}$, while the lower 5 samples all have means greater than $200 \mu \mathrm{m}$.

Point counting for roundness reveals a decreasing roundness downcore, although the top sample $(4.5 \mathrm{~m})$ has a measurement of 3.33 compared to the lower four samples range of 3.11-3.19. Mineralogy change shows a decrease of quartz and feldspar downcore as the percent of lithics increase.

\subsubsection{Age control}

A single fragment of wood from the AB4 core was radiocarbon dated. This sample was taken at $7.4 \mathrm{~m}$ within the organic deposit and returned a radiocarbon age of $33482 \pm$ $701 \mathrm{BP}$. 


\subsection{Waikanae Beach Foredune Transect}

\subsubsection{Description}

A transect was surveyed, described and sampled across an active prograding dune at Waikanae Beach (Gibb, 1978b). The site of the transect is seven hundred metres north of the Waikanae River (figure $2.1 \& 4.22$ ). As the cores from this study were deposited in a prograding coastal system, this transect was undertaken to improve the understanding of the relationship between the shoreface and dune environments. Fourteen points across the transect were sampled and described at the surface and subsurface (figure 4.23). The distance between each point was measured as well as the relative elevation change. The sediment samples were analysed for grainsize and point counted for roundness and mineralogical composition. This location was chosen because it faces the prevailing NW winds (Baldi et al., 2007) and is one of the few places that was in a prograding state at the time of the survey.

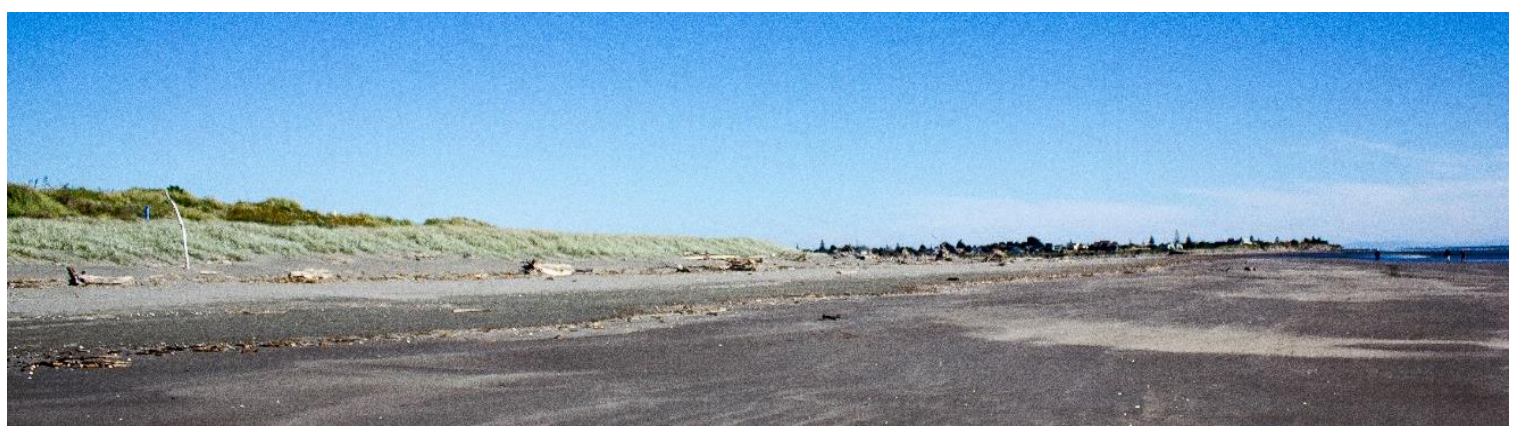

Figure 4.22: Photo of the location for the Waikanae Beach transect, looking south towards the Waikanae river. To the right is the foreshore during a low tide, on the back left is the dark green established vegetation of the back dune. The light green, established marram grass is visible covering the foredune, extending from the left towards the south. 


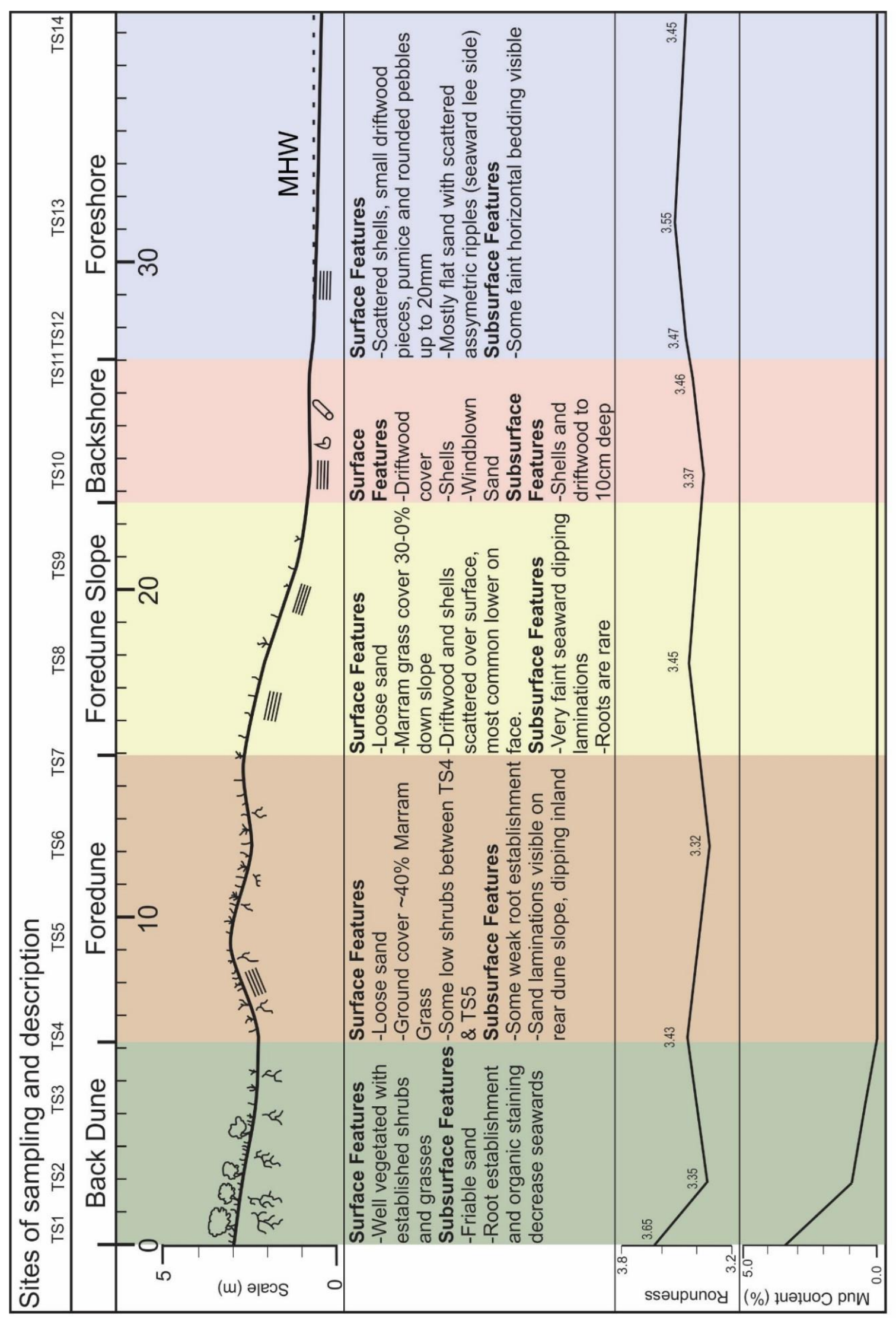

Figure 4.23: Caption on following page. 
Figure 4.23 (previous page): Graphic of the Waikanae Beach transect. The top bar Shows an elevation of the transect with a graphical representation of the surface and subsurface features seen at each site. The roundness measurements for the sample are displayed as well as the mud percent for each sample.

Sites TS1, TS2 and TS3 are located at the inland end of the transect on seaward facing slope. The surface for this section was well vegetated with shrubs (up to $1.5 \mathrm{~m}$ tall), grasses and other plants. The subsurface of this location was composed of an organic stained sand with an abundance of well-established roots.

On the landward dipping slope of the back of the foredune, from TS4 to TS5, the loose sand surface has minimal vegetation with some small shrubs and an increased amount of marram grass compared to that at TS1-TS3. The subsurface of this segment has some faint root networks established that reflects the minimal ground cover. Laminations were also visible in the subsurface, dipping inland oriented near parallel to the surface of the section.

From TS5 to TS7 the vegetation decreases again with the only ground cover on the loose sand being marram grasses, covering $\sim 40 \%$ of the surface. The subsurface shows similar root establishment to that of TS4-TS5.

The seaward dipping slope of the foredune was measured as the section from TS9 to between TS9 and TS10. This slope is covered in loose sand with the marram grass cover decreasing from $\sim 30 \%$ at the crest of the slope to $0 \%$ at the base. Driftwood pieces up to $2 \mathrm{~m}$ as well as whole and broken shells are common towards the base of the slope.

The backshore division incorporates sites TS10 and TS11. The surface of this division is covered in a large amount of driftwood, mostly less than a metre in length but occasionally reaching two metres. Spread through this driftwood are shells varying from whole to angular or rounded pieces. Small piles of windblown sand are present across the top of the driftwood. The subsurface of these two sites consists of buried shells and driftwood up to $10 \mathrm{~cm}$ deep. 
The three sample sites closest to the ocean are TS12, TS13 and TS14. The surface of these sites are scattered with broken and whole Paphies subtriangulata shells as well as small rounded pebbles up to $20 \mathrm{~mm}$ in size. Driftwood and pumice pebbles up to $5 \mathrm{~cm}$ in diameter are also scattered across this surface. The wet sand of these sites has asymmetric ripples, orientated with their lee-side towards the sea. The subsurface of these three sites shows faint horizontal laminations.

\subsubsection{Grainsize}

Grainsize of these samples is remarkably consistent (figure 4.24). The only variation in distribution is seen in samples are the TS1, TS2 and TS3, which all show a slight silt component. Throughout all samples the modal grainsize ranged from 185.5-203.7 $\mu \mathrm{m}$. All samples are either well-sorted or very well-sorted.

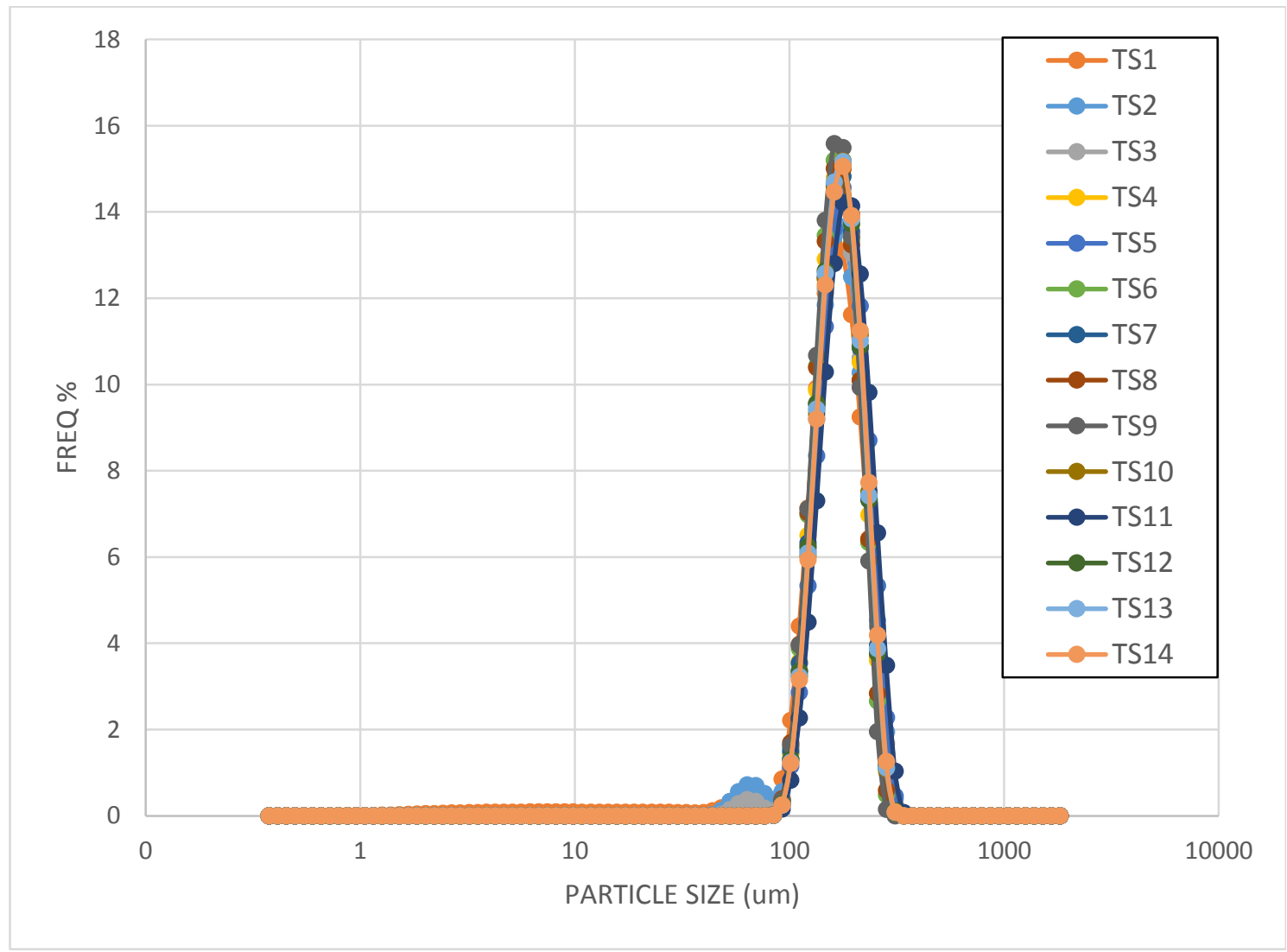

Figure 4.24: Grainsize distribution for all samples in the transect shows their sorted distribution. The TS1, TS2 and TS3 samples have a very slight silt content (also visible in figure 4.23). 


\subsubsection{Roundness and Mineralogy}

All samples except TS3, TS5, TS7 and TS9 were analysed for roundness and mineralogy.

All samples showed a consistent roundness value, ranging from 3.65 (TS1) to 3.35 (TS2)

(figure 4.23) across the transect with no clear trend across the transect. The

mineralogy of each sample was at least $50 \%$ lithic grains with the remainder being made up of quartz, feldspar and other grains (figure 4.25). The values for mineralogy show similar values, except for the TS6 and TS11 samples which displayed an increased lithic component and a relative decrease in the percentage of quartz. Demonstrating there is no obvious separation or sorting based on environment across the beach/dune transect.

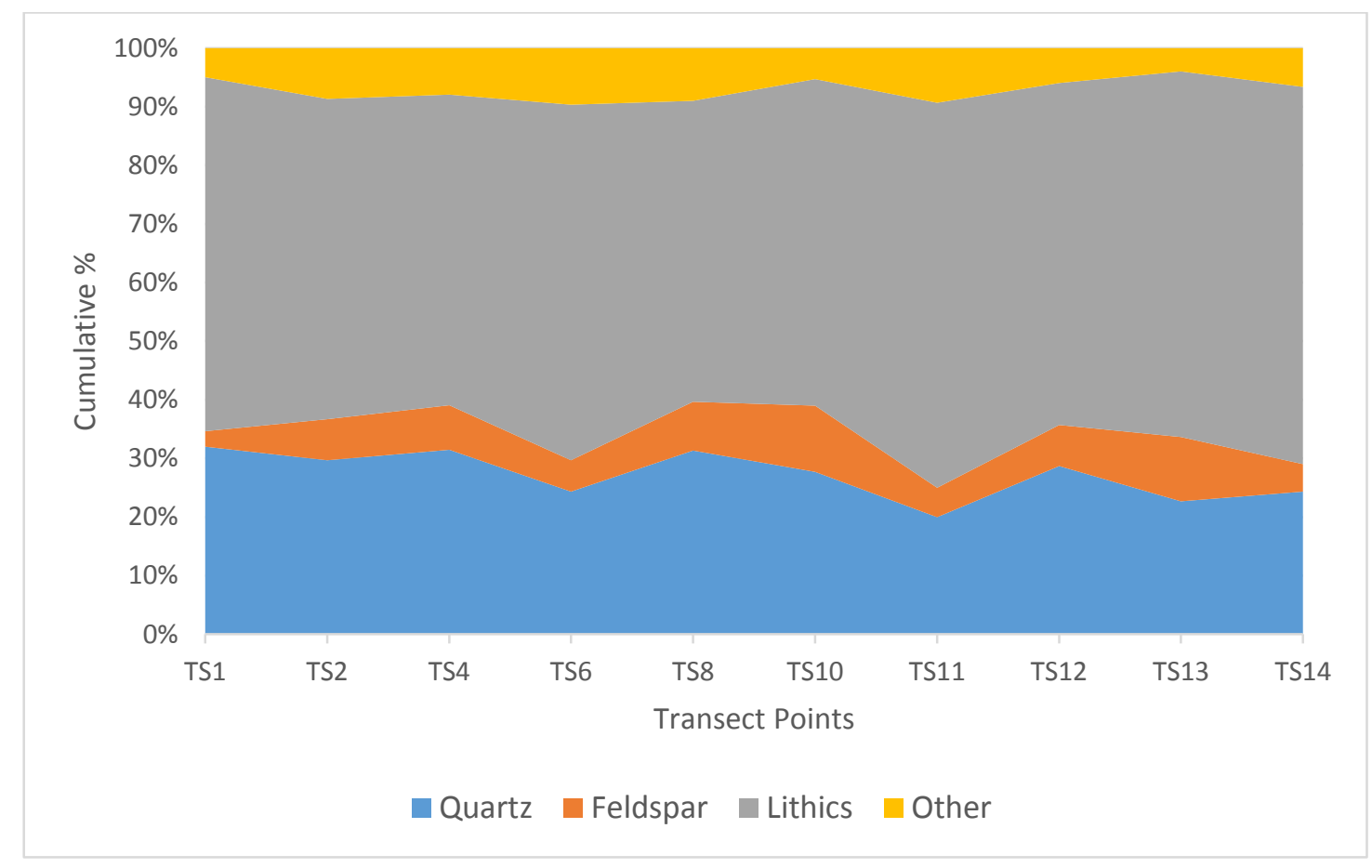

Figure 4.25: Stacked grainsize composition for the Waikanae Beach transect samples. The dominant component is the lithic material, followed by the quartz, feldspar and finally the other category. The relative composition of the samples shows a near consistent composition across all samples, except the TS6 and TS11 samples which have an elevated lithic composition and decrease in the quartz component. 


\section{Facies Analysis}

Walker and James (1992) describe a facies as a unit of rock that is characterised using lithological, physical, and biological characteristics to differentiate it and the units above and below. From the lithostratigraphic units described in the cores and outcrops, eleven lithofacies have been recognised. Each of these individual lithofacies is distinguishable based on a set of identifiable characteristics. Each facies carries an interpretation of the environment for deposition, this is based on key characteristics recognised for these environments from the literature. The aim of the facies scheme is to relate beds from different outcrops and cores, allowing the recognition of deposits formed under similar depositional processes.

Association with facies above and below are recognised and assist the interpretation of depositional environment. Commonly recognised sedimentary subdivisions seen on a prograding coast have sedimentary structures that are formed by processes that operate in that environment (figure 2.4). On a typical prograding coast, these form the basis for an idealised vertical facies succession and are recognised throughout the literature as signatures of the environments they were formed in (figure 5.1). However, the lack of these features in the units from this study has necessitated the formation of a bespoke facies scheme. Therefore the facies scheme is based on features recognised in unit description and is also informed by the modern Waikanae Beach transect, this greatly assists with the environmental interpretations of the facies associations. 


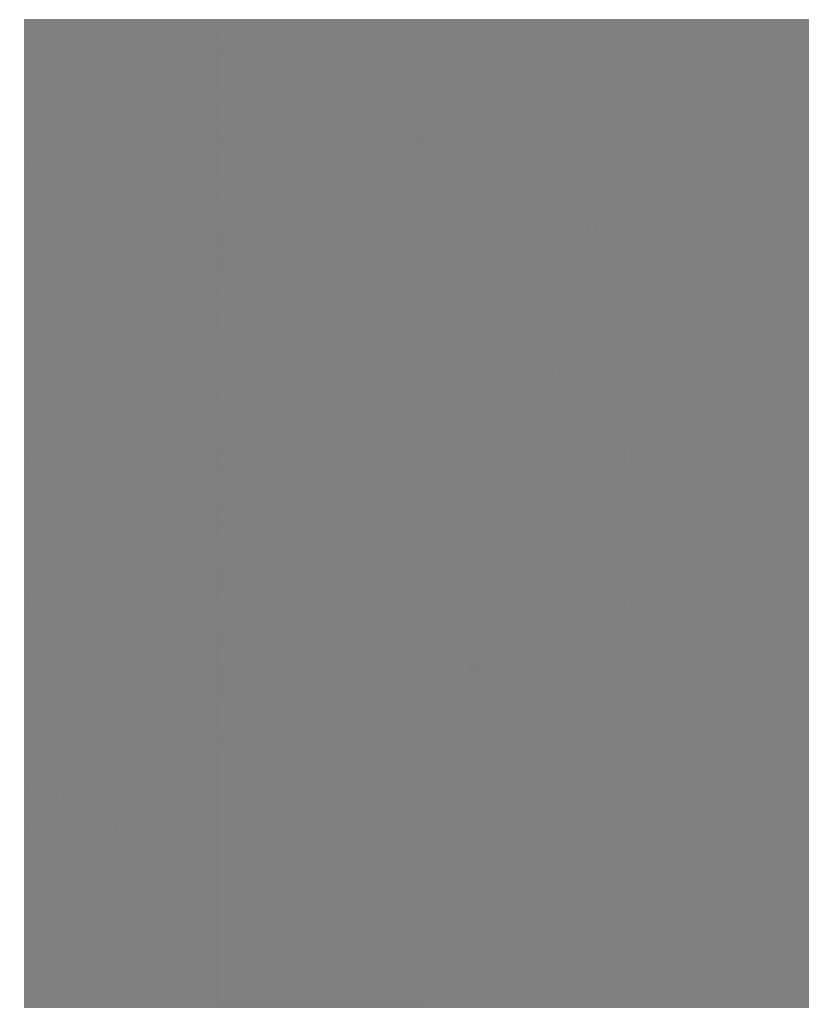

Figure 5.1: A generalised vertical succession of foreshore and nearshore environments and their distinct sedimentary structures, as anticipated on a prograding sedimentary coast. Reproduced from Boggs (2011).

Through the process of recognising the association and succession of facies in the outcrops and cores collected in this study, a depositional model is produced. In addition to the facies descriptions, the model can be used to anticipate the succession of facies that is expected for different locations

\subsection{Facies Classifications and Associations}

Eleven lithofacies have been recognised, with interpretations ranging from shoreface deposits to anthropogenic earthworks. The facies comprise two main lithologies, conglomerates and sands. The conglomerates range from poor to well-sorted with variable bedding, while the sands are separated on the basis of the incorporated material and the style of bedding or sedimentary structures visible.

\subsubsection{Poorly-sorted, Angular Conglomerate - CG1}

Conglomerate, typically light brown-grey depending on the matrix. Clasts are Torlesse sandstone, angular to sub-angular up to $50 \mathrm{~mm}$ in size, predominantly clast supported (figure 5.2) with no preferred orientation of clasts. Matrix ranges from brown fine-sand to grey muddy-sand. The sorting is poor. This facies may display bedding as a change from clast to matrix supported beds. The matrix supported sandy units show no 
bedding, and contain common angular Torlesse sandstone clasts and these units share gradational contacts with CG1 conglomerates. Presence of wood and other organic fragments varies. The thickness of this facies varies in thickness from $0.5-3.5 \mathrm{~m}$, with gradational or sharp lower contacts.

The poorly-sorted angular clasts in this facies are interpreted as a modern anthropic deposit (Ford et al., 2014), formed through the manipulation of the landscape (Ford et al., 2010). The locations of the core sites aided the interpretation of this facies, the WS3 core was drilled through the surface of a gravel car park (figure 4.12), while the cores $A B 1, A B 2$ and $A B 4$ were drilled through the asphalt runway of the airport. In addition to this, the clasts in this facies have undergone minimal rounding, suggesting that the method of transport and deposition for these rocks is unlikely to have been fluvial processes. The interbedding of clast and matrix is interpreted as layering of the fill between local material (sand) and introduced fill (gravel). The nature of the base of the fill explains the variation in the contact, whether it is similar (gradational) or different (sharp) to the underlying lithology.

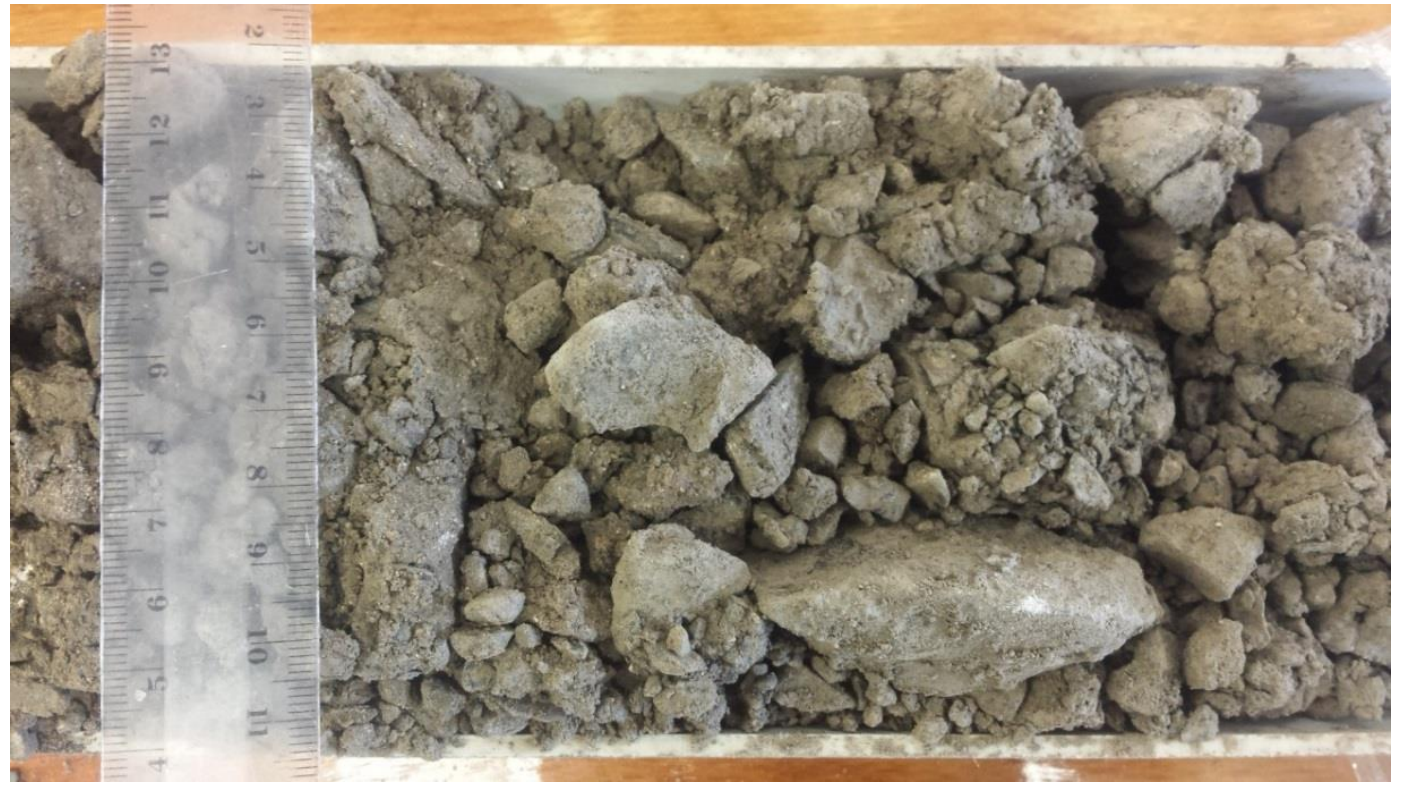

Figure 5.2: The poorly-sorted CG1 conglomerate. Interpreted as fill from modern construction and earthworks. 


\subsubsection{Sandy Conglomerate - CG2}

Grey, sandy conglomerate of sub-rounded Torlesse sandstone clasts up to $50 \mathrm{~mm}$ in size, moderately-sorted. Clasts are disc and oblate in shape. Matrix is a mediumgrained, grey sand. Matrix supported. Occasional scattered bivalve shell hash. Thickness of this facies is no greater than $0.5 \mathrm{~m}$, lower contact is gradational. Interpretation for this unit is a gravel deposit in a foreshore environment, washed by wave activity (Kirk, 1980, Hart and Plint, 2003, Are et al., 2003). The sub-rounded clasts in this facies are indicative of a moderate-high energy environment (Boggs, 2011), which is supported by the presence of broken shell fossils within this facies. The disc and oblate clasts are indicative of a foreshore environment (McLean and Kirk, 1969). The gradational lower contact and thickness of this facies support the interpretation that this deposit has been formed of gravel distributed across the foreshore, forming laterally adjacent deposition in the same environment (Middleton, 1973) (figure 5.3).

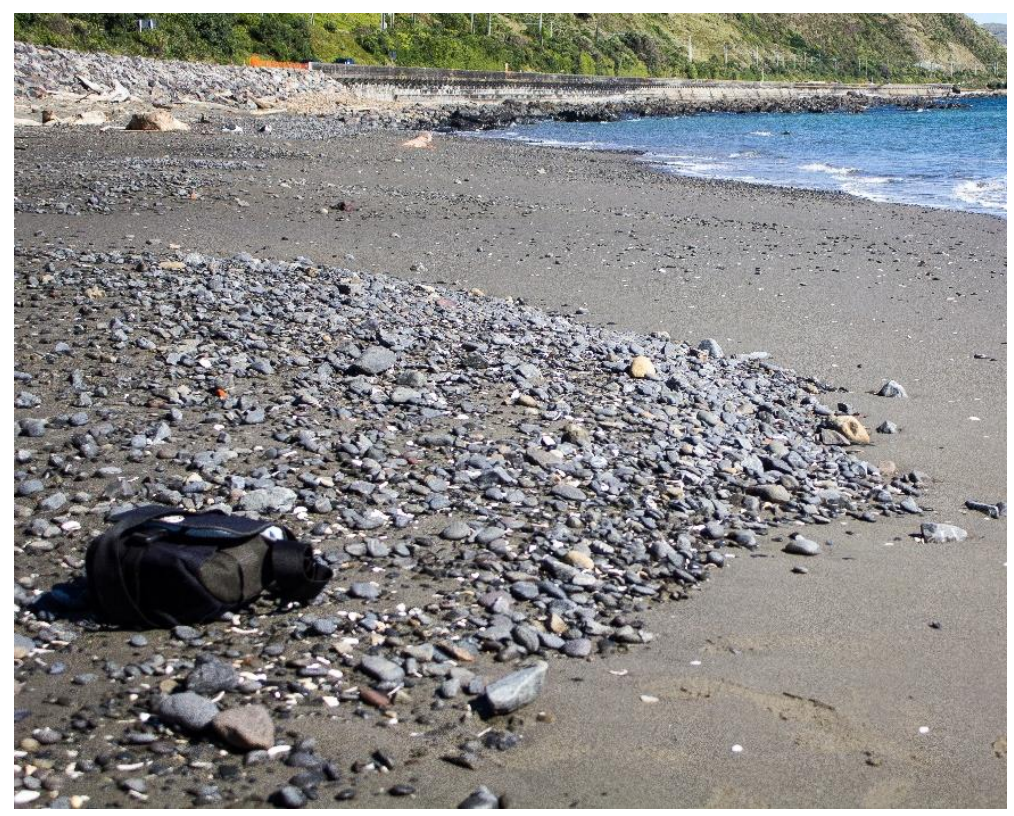

Figure 5.3: A deposit of gravel on a modern foreshore at the southern end of the Kāpiti Coast. This is the depositional setting that is interpreted for the CG2. Bag is $25 \mathrm{~cm}$ across.

\subsubsection{Stratified Conglomerate - CG3}

Dark brown, sandy conglomerate, poorly-sorted. Matrix supported. Clasts are Torlesse sandstone, averaging $4-5 \mathrm{~cm}$ up to $20 \mathrm{~cm}$ in size, with clast roundness varying from angular to sub rounded. The matrix is a poorly-sorted, brown, fine-medium sand, with common Torlesse sandstone pebbles and granules. This facies displays bedding in 
laterally continuous planar beds and also lenses, as well as infilled channel structures (figure 5.4). Some parts of this facies appear as well-bedded brown sand beds, and contain common Torlesse sandstone pebbles. Bedding is visible as a change in clast size and the ratio of clasts to matrix. Bed thickness ranges from $2-30 \mathrm{~cm}$. This facies is typically no thicker than $1 \mathrm{~m}$ with a sharp wavy lower contact.

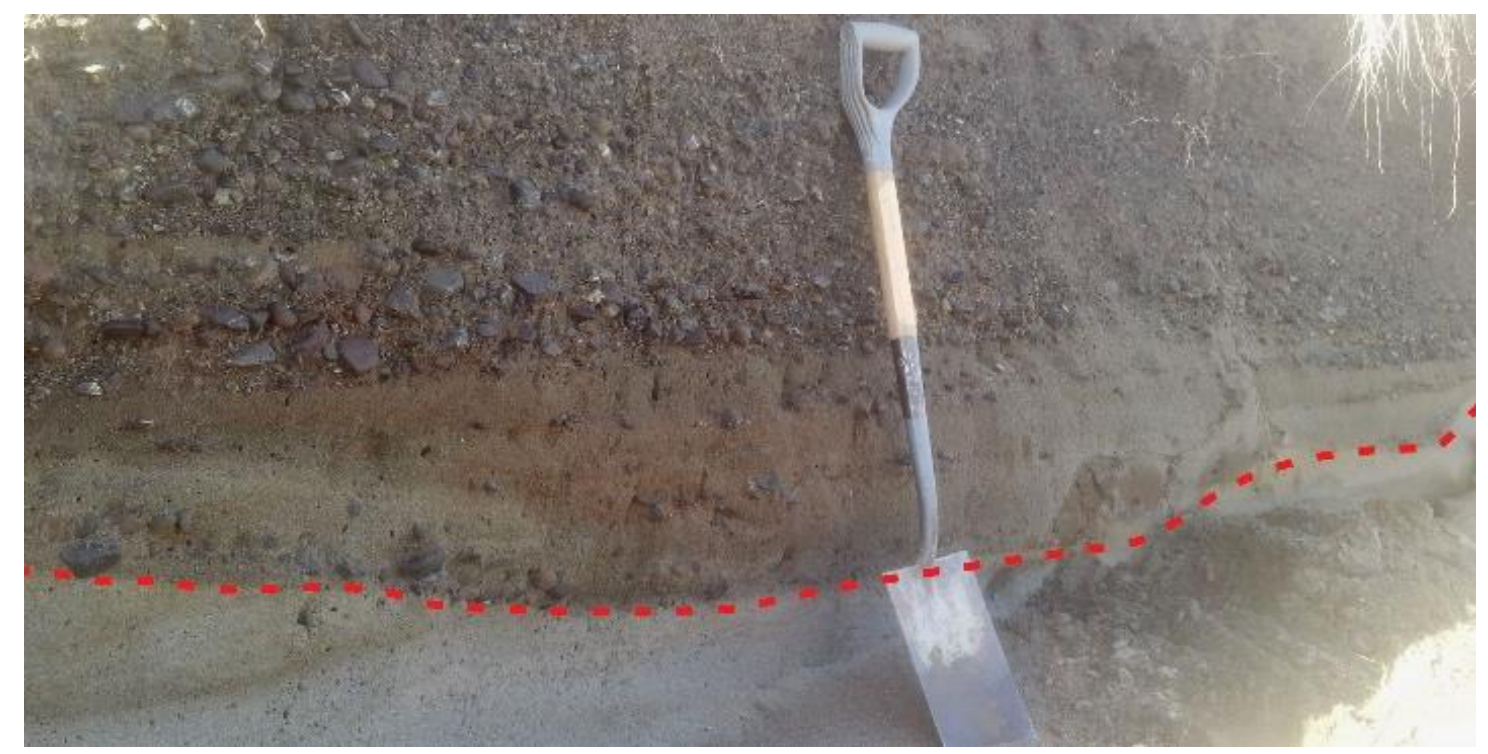

Figure 5.4: Photo of the infilled channel structure and thin conglomerate beds and lightly stratified $1-2 \mathrm{~cm}$ sand beds within the CG3 facies at the NFT site (spade stands $1 \mathrm{~m}$ high).

This facies is interpreted as being deposited in a foreshore environment, influenced by fluvial and marine processes. The large size of the clasts in this facies suggests the influence of a high energy environment, where a fluvial stream mouth intersects the foreshore (figure 5.5) (Davis, 2012). The thin, laterally extensive planar beds of clasts seen suggest influence of periods of greater than average wave energy sorting clasts into thin sheet deposits (Kumar and Sanders, 1976, Nielsen and Nielsen, 2006). The diversity of roundness for these clasts suggest that the amount of abrasion for each clast has been inconsistent (Sneed and Folk, 1958), with more than one process. The combination of the fluvial channels, and planar sheet bedding suggests an environment influenced by marine and fluvial processes, while the diversity in roundness supports the interpretation of overlapping processes. 


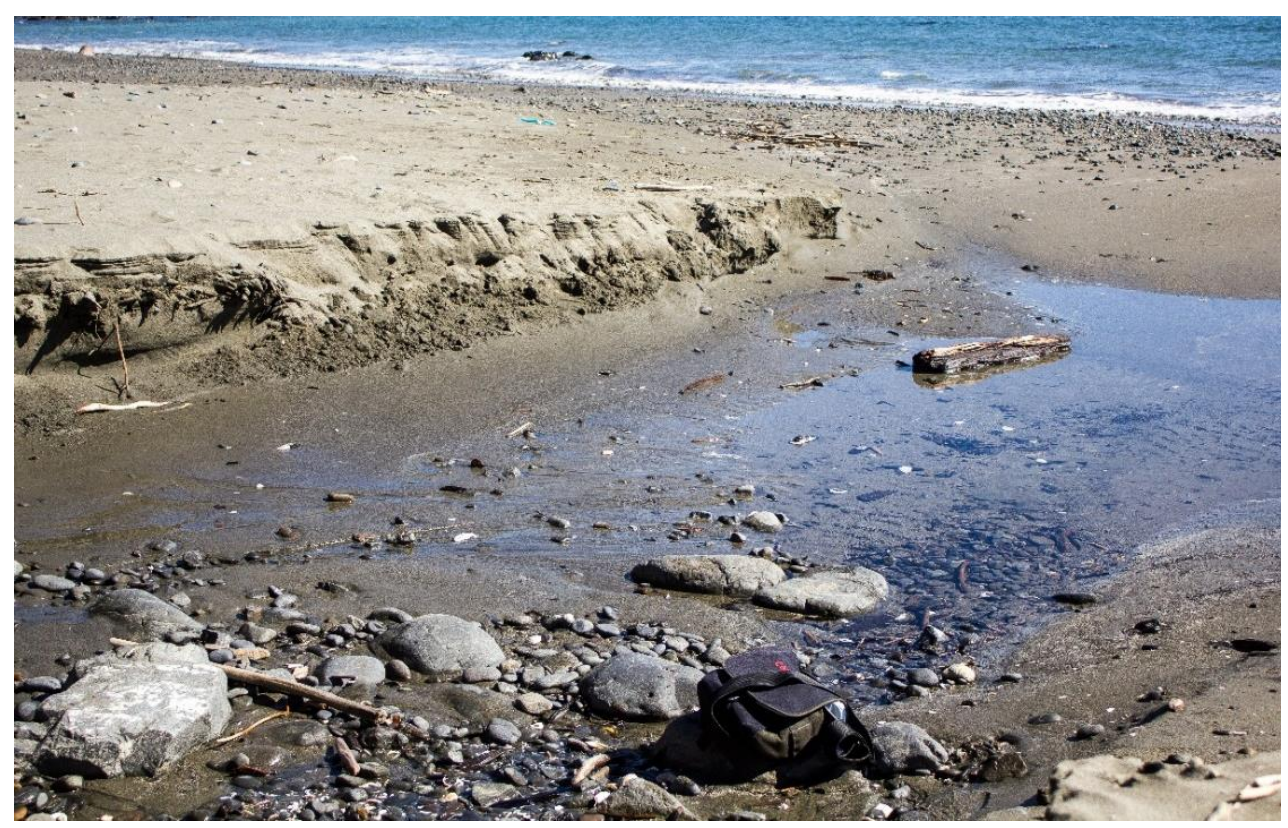

Figure 5.5: The modern interpretation of the CG3 facies. Gravel and cobbles

deposited by a small stream into the tidal zone of a sandy foreshore, $5 \mathrm{~m}$ north of the SFT outcrop where the CG3 facies is visible. Camera bag in foreground is $25 \mathrm{~cm}$ across.

\subsubsection{Fine-sand - S1}

This facies is a brown, silty, fine-sand. Variable sorting. Bed thickness varies from 10$20 \mathrm{~cm}$, occurring as planar cross laminated beds (figure 5.6). Horizontal, dark organic staining up to $20 \mathrm{~cm}$ thick is common within this facies, as well as roots and other organic fibrous material. Small well-rounded Torlesse sandstone pebbles are present in this facies, however they are uncommon. Typical grainsize characteristics for this facies displays a modal grainsize of $169-203 \mu \mathrm{m}$ and a percent mud of $10-30 \%$. This facies is typically thicker than $2 \mathrm{~m}$ with a sharp or gradational lower contact.
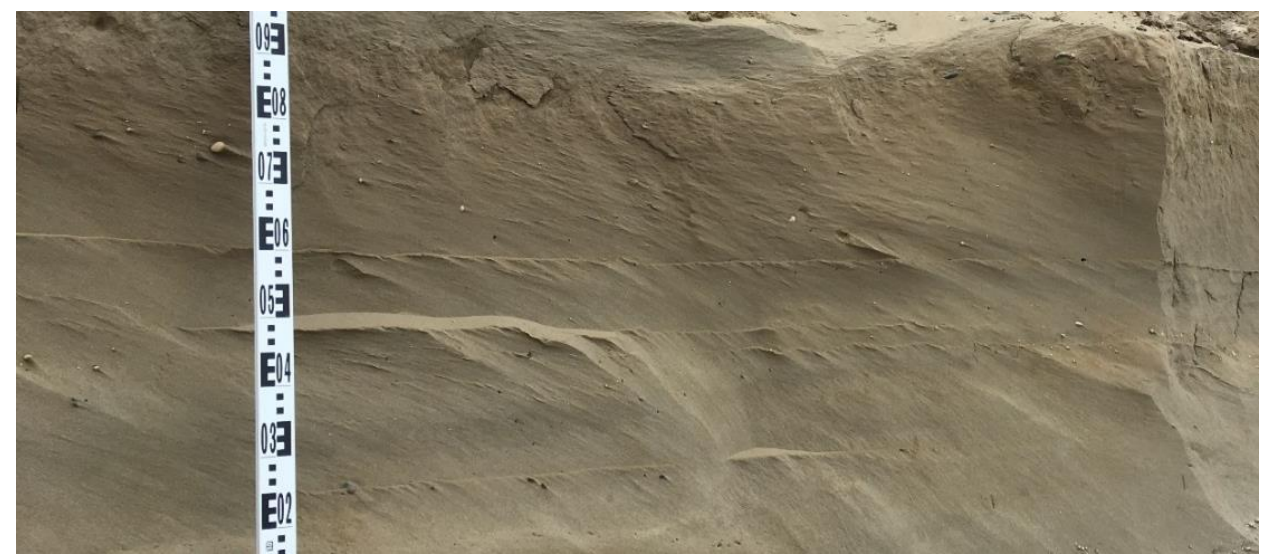

Figure 5.6: The planar cross laminated beds of the fine brown sand in the S1 facies. Scale bar shows numbered $\mathrm{dm}$ increments. 
The feature of this facies that informs the interpretation to the greatest extent is the roots, soil horizons and other terrestrial fossils. The fine-sand and mud content of the grainsize samples from this facies, is typical of a windblown dune deposit (Bristow et al., 2000). Soil horizons are a common feature in the internal structure of the dunes on the Kāpiti Coast (Hawke and McConchie, 2006) and are a product of slowed deposition and increased surface vegetation leading to the development of a soil. The scattered pebbles in this facies are a result of foreshore material being moved onto and beyond the foredune slope by storm over wash (Nielsen and Nielsen, 2006). This increased wave energy is also attributed to shifting driftwood onto the foredune slope of the Waikanae Beach transect.

\subsubsection{Fine-sand with Pumice - S1V}

This is a brown, fine-sand with scattered light-coloured pumice clasts or fragments. This facies is a subcategory of $\mathbf{S 1}$, and is defined by pumice content. The pumice is white to grey in colour, with some grey-banded clasts. Clasts range from $2 \mathrm{~mm}$ up to $30 \mathrm{~cm}$, however most are around $2-4 \mathrm{~mm}$ with occasional pebbles up to $15 \mathrm{~cm}$ in size. Clasts are typically rounded, but frequently broken and angular pieces are common. These deposits occur within the same well-sorted, brown, fine-sand of the S1 facies. In some places the pumice is interbedded with the sand, as well as being mixed. Bedded deposits defined by alternations of well-sorted and poorly-sorted sand. The wellsorted beds contain pumice granules and small clasts up to $\sim 4 \mathrm{~mm}$ and occur in beds no thicker than $3 \mathrm{~cm}$. At the northern Fisherman's Table measured section, these deposits dip inland $\sim 30^{\circ}$ (figure 5.7). The poorly-sorted beds are no thicker than $20 \mathrm{~cm}$ and consist of a mix of clast sizes up to $30 \mathrm{~cm}$, the beds appear undulating with a relief of up to $50 \mathrm{~cm}$.

The depositional environment of this facies is similar as the dune environment of the S1 facies. Ocean rafted pumice has been recognised as part of shoreline deposits around New Zealand (Wellman, 1962, McFadgen, 1985) and the dune sequences of the Kāpiti Coast have a high pumice content (Cowie, 1963, Fleming, 1972), this volcanic material is interpreted to have arrived at the foreshore by longshore drift from the north. The pumice is interpreted to have been deposited within the dune through wind and storm wave action. Dune orientation is evident in the interbedded pumice and sand deposits from the dip and dip direction of the beds (figure 5.7) indicating 
deposition on the rear face of a dune form (Fryberger et al., 1979, Bristow et al., 2000), blown over by a westerly wind. The poorly-sorted deposits of pumice clasts, most 2$30 \mathrm{~cm}$ in size, similar to the pebbles in the $\mathrm{S} 1$ facies, and the driftwood on the foredune of the transect are interpreted to be a wash deposit from large waves (Nielsen and Nielsen, 2006).

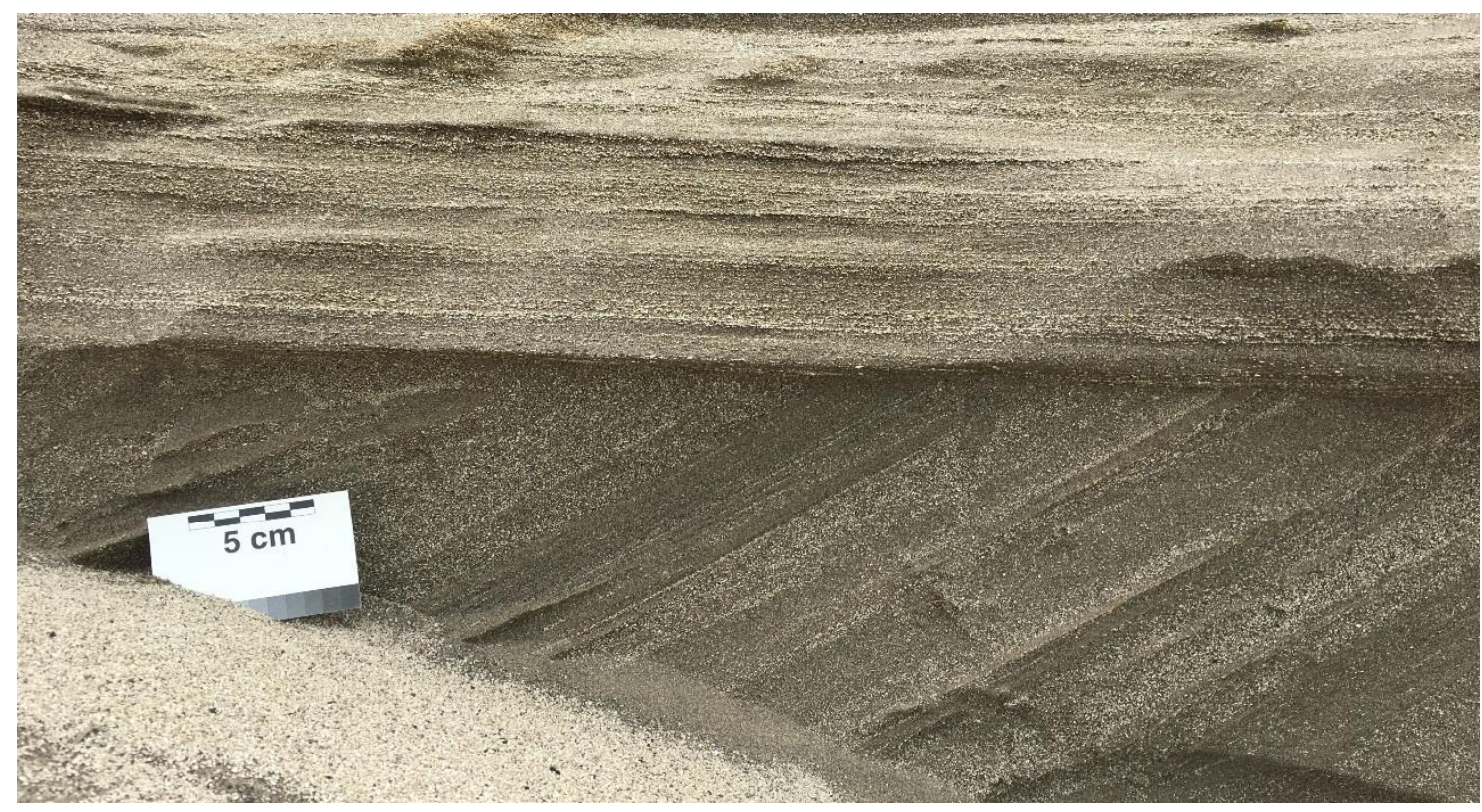

Figure 5.7: Dipping and horizontal laminations in the S1V facies formed of white pumice grains (visible bottom left) amongst brown sand. This is located at the NFT outcrop. A significant bedding truncation surface is visible through the middle of this image.

\subsubsection{Mineralogically Diverse Sand - S2}

A brown medium-fine-sand, poor to moderately-sorted. The sand in this facies shows a distinctive diverse mineralogy, with amphiboles, orthoclase, micas and volcanic material visible in hand sample. Some faint, thin horizontal bedding is visible in this facies. Paphies subtriangulata and Dosinia sp. fossils (Beu and Raine, 2009) occur in this facies in varying conditions from whole to angular and well-rounded broken pieces. Typically this facies is no thicker than $2 \mathrm{~m}$, with a sharp or gradational lower contact.

The horizontal bedding recorded in this facies are a commonly recognised feature of the foreshore environment (Boggs, 2011, Reinson, 1979), as well as variations in the sorting of sediment (McLean and Kirk, 1969) driven by the variations of the incident wave energy (Kolmer, 1973). The minerals present in the sand of this facies are the 
same as those seen in the foreshore sand on Kāpiti Coast beaches in the present day (Kasper-Zubillaga and Dickinson, 2001), supporting the interpretation of this facies as a foreshore deposit. The volcanic materials present, originate from the volcanic provinces of Taranaki and the central North Island transported along the coastline by longshore drift (Gibb, 1978a). The presence of the upper shoreface-foreshore bivalves Paphies subtriangulata and Dosinia sp. (Beu and Raine, 2009) support the foreshore interpretation, while the condition of the fossils indicate a high energy regime to separate and fracture the initially articulated bivalves.

\subsubsection{Finely Laminated Sand - LS2}

A grey, fine-medium sand, regularly laminated with light-grey, silty fine-sand. The sand is well-sorted with no other sedimentary structures visible (figure 5.8). The laminations are regular, with sand lamina up to $10 \mathrm{~mm}$ thick, while silty-sand lamina are no thicker than $6 \mathrm{~mm}$. No fossils are present in this facies. The high silt content is evident in a bulk grainsize analysis of this facies from the $A B 3$ core, containing a mud content of $48.2 \%$ with a modal grainsize of $169 \mu \mathrm{m}$. Facies is $0.4-0.6 \mathrm{~m}$ thick, with a gradational lower contact.

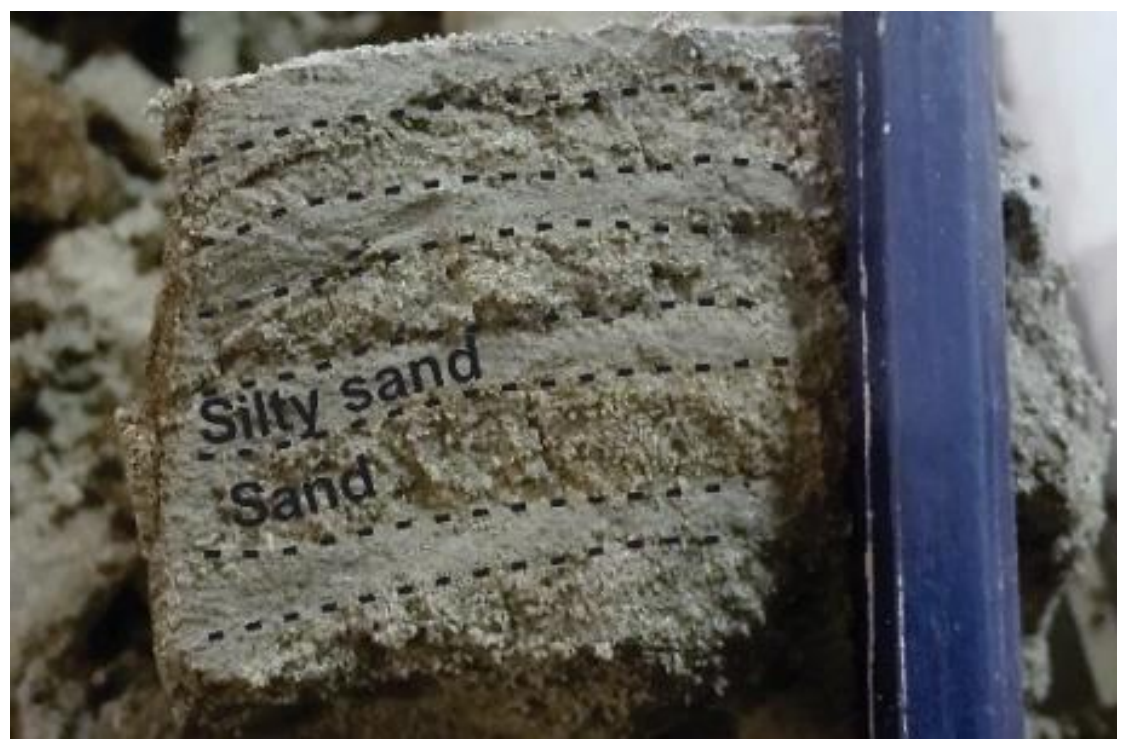

Figure 5.8: The finely laminated bedding in the LS2 facies (pencil is $8 \mathrm{~mm}$ wide).

This facies is a subset of the $\mathrm{S} 2$ facies, a foreshore setting. The depositional process that deposited these laminations is recognised in two separate processes acting upon the same environment. The first is the windblown transport of sand and silt over dry ground, free from the influence of water (Hummel and Kocurek, 1984). The second is the continued action of wave swash across the surface of sand (Clifton, 1969, Reinson, 
1979). These laminations also compare to those seen in the foreshore environment in the Waikanae Beach transect (figure 4.23). While there are two potential depositional processes for this facies, the interpretation of the depositional environment remains the same.

\subsubsection{Brown Sand - S3}

A brown, fine-grained sand. This facies varies from poor to well-sorted. Some parts of this facies are well-bedded, with upwards fining deposits of organic mud and fibres (figure 4.13) as well as grey mud laminations. Fossils are unidentifiable shell hash up to $15 \mathrm{~mm}$ in size. Well-rounded, Torlesse sandstone pebbles up to $30 \mathrm{~mm}$ across are present in this facies, scattered individually throughout or in small lenses. The typical modal grainsize of this facies is $154-203 \mu \mathrm{m}$ while the mud content varies from $0-38 \%$. The thickness of this facies ranges from 1-6m, while the lower contact is gradational. The grainsize distribution from this facies showed variability with depth, however the percentage of mud was similar to that of shoreface samples taken between Otāki and Waikanae (Dunbar and Barrett, 2005, Perrett, 1990), leading to the interpretation of a shoreface deposit (Boggs, 2011). The source of the mud in the laminated deposits, is interpreted to be suspended from the shoreline, either through wave energy stirring the sediment or river outflow (Rachold et al., 2000), settling beyond the influence of shoaling waves (Jaffe et al., 1985). The graded deposit is a result of decreasing wave energy following stormy periods, allowing the settling of gradually finer material (figure 4.13) (Boggs, 2011). The Torlesse sandstone pebbles in this facies have undergone a high degree of wear through transport to achieve the well-rounded appearance. Bedded gravel deposits in the shoreface environment have been attributed to periods of increased wave energy (Cheel and Leckie, 1992), while the scattered pebbles are attributed to downslope sediment transport from the foreshore (Hart and Plint, 1989, Hernández-Molina et al., 2000).

\subsubsection{Grey Sand - S4}

A grey, very fine-grained sand, well-sorted. Fine laminations of mud and/or organic material are common throughout this facies but show no uniform distribution. Scattered Torlesse sandstone granules and pebbles are present, these are well rounded. The fossils identified in this facies are broken and species include Tanea zelandica (figure 5.9), Paphies sp. and Dosinia sp. and occur scattered through the 
facies. Shell hash is also commonly found in lenses within this facies. The modal grainsize of samples taken from this facies varied from $116-223 \mu \mathrm{m}$ with samples having a mud component varying from $0-37 \%$. No lower contact was observed for this facies.

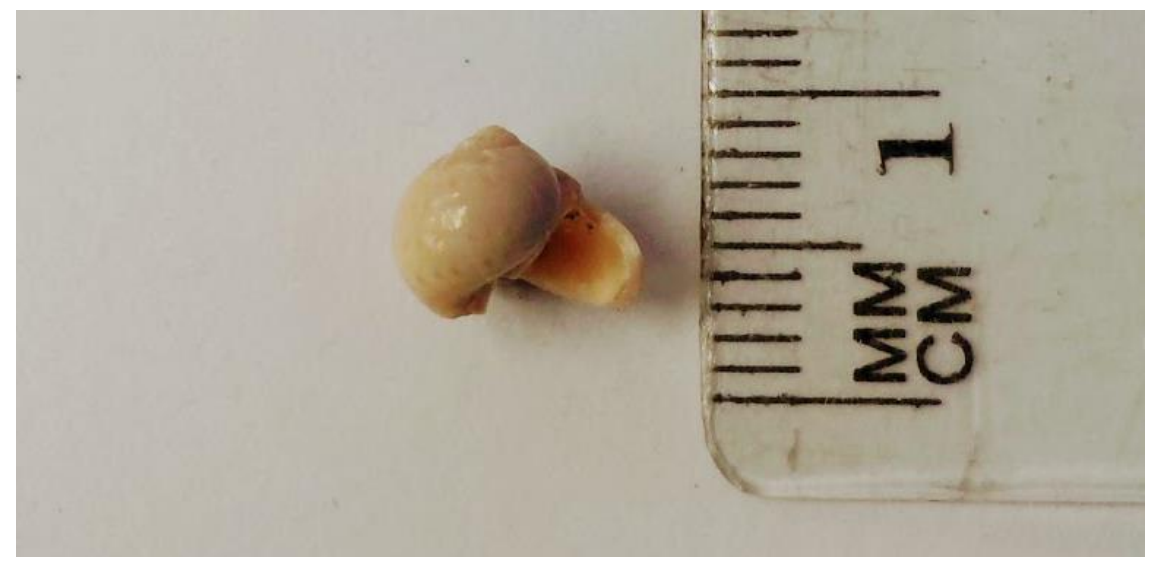

Figure 5.9: The broken juvenile Tanea zelandica from $22.15 \mathrm{~m}$ deep in the WS3 core.

Results from grainsize analysis of samples taken from this facies, revealed a mud component, that was similar to some modern day samples from the shoreface of the Kāpiti Coast (Perrett, 1990). The very fine-sand with a high mud component is a signature of sediments from the shoreface of the Kāpiti Coast (Dunbar and Barrett, 2005). This facies is finer and muddier than the $S 3$ facies and likely represents deposition in slightly deeper water. The upper shoreface-foreshore species Paphies sp. and Dosinia sp. show evidence of transport in the broken condition of the shells, transported through the same process as the downslope transport of the scattered pebbles in this facies (Hart and Plint, 1989, Hernández-Molina et al., 2000). The Tanea zelandica found in this facies are a common species in shallow water deposits around New Zealand (Beu and Raine, 2009), however juvenile species such as this one have been recognised as a common occurrence in modern shoreface sediments from the Kāpiti Coast (Perrett, 1990). This facies is the lowest recognised in this study and as a result no attempt is made to differentiate it from lower or mid shoreface divisions, instead it is treated as an overarching low-mid shoreface facies, separate from the upper shoreface. 


\subsubsection{Sand With Organic Fibres - OG1}

A sand with a dark-brown, mottled, organic-rich colour. This common organic material is in the form of small $(<5 \mathrm{~mm})$ fibres, flakes and seeds. The organic material shows no preferred orientation or sorting. This facies is up to $30 \mathrm{~cm}$ thick with a sharp lower contact.

This facies is interpreted as a deposit of terrestrial plant material that has been deposited on the foreshore, proximal to the high tide mark. This type of deposit is common on shorelines of large bodies of water (Kramer and Wohl, 2015) and is commonly seen along the Kāpiti Coastline (figure 5.10). The material is supplied through terrestrial sources transported by streams and rivers and distributed on the foreshore through processes of wave and tidal activity (Are et al., 2003).

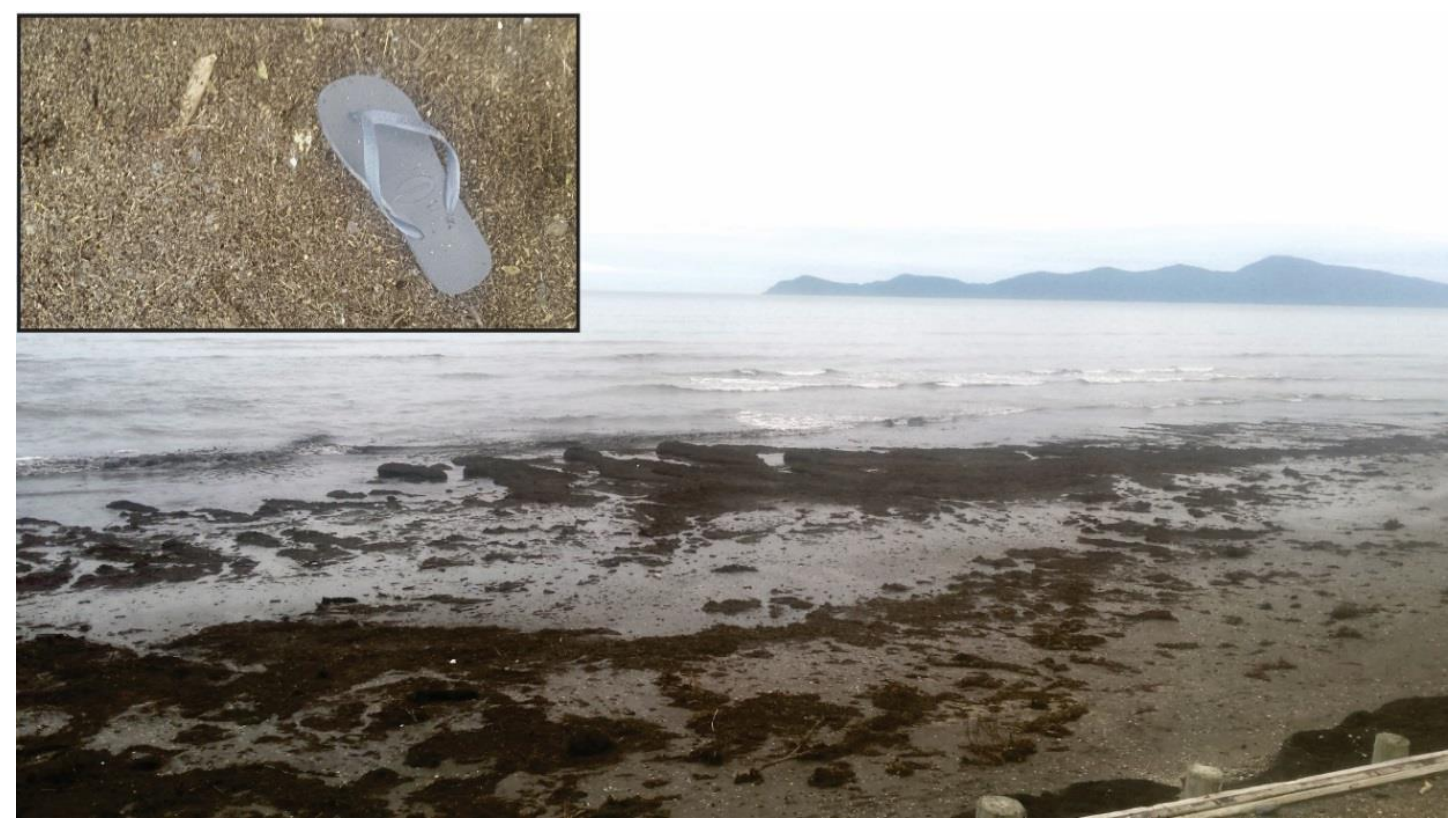

Figure 5.10: A drifted deposit of wood pieces and other organic fibres below the high tide line on the beach at Paekakariki. Deposits of this extent are common on Kāpiti Coast beaches during the summer, while smaller drifts occur all year round. Inset: A close up of the wood fibre mat (jandal is $27 \mathrm{~cm}$ long). 


\subsubsection{Organic Stained Sand OG2}

A fine, brown sand with extensive organic staining. The colour ranges from light to dark brown. Laminations of organic-rich mud are common in this unit, while grainsize analysis reveals an overall elevated mud content up to $37 \%$. Root structures and fibres are very common in this facies. This facies is commonly $1-2 m$ thick, with a gradational lower contact.

This facies is interpreted as being deposited in a vegetated, wetland dune environment (figure 5.11). The fine-sand of this facies is similar to that seen in the $\mathrm{S} 1$ facies (Bristow et al., 2000). An elevated mud content is observed in the back dune vegetated part of the Waikanae Beach Transect (figure 4.23), the origin of this is likely a result of windblown silt being deposited and trapped amongst vegetation. The organic staining and root structures are due to continued vegetation of the surface and increased tannin production within the dunes (Byrne and McCann, 1990, Luly et al., 2006).

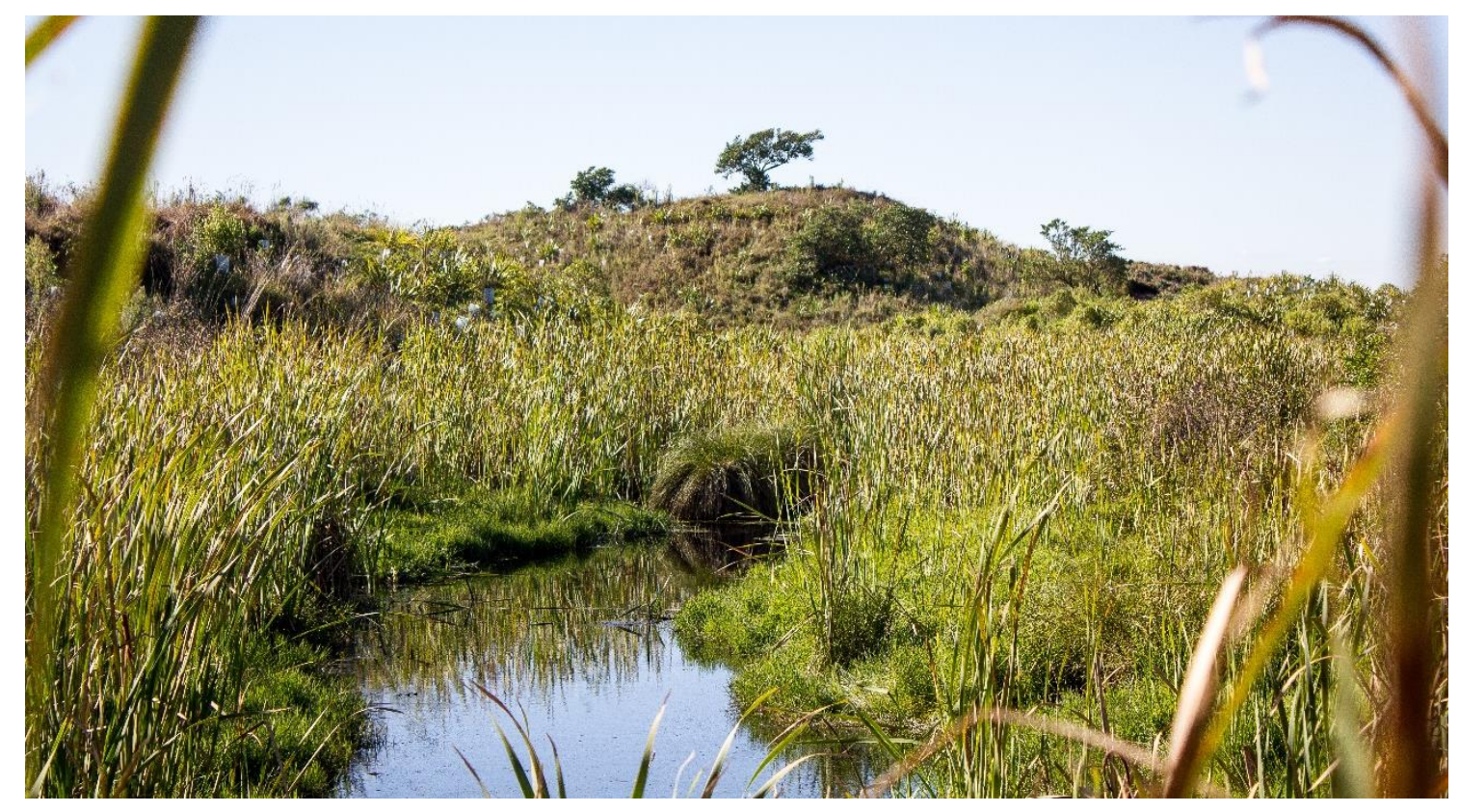

Figure 5.11: The interpreted environment of the OG2 facies. A pond has formed in this back dune hollow due to the impeded drainage behind the dune crest (centre frame) with well-established reeds, flax and grasses. The body of water in the foreground is $2 \mathrm{~m}$ across. 


\subsection{Facies Allocation}

The lithostratigraphic units recognised in this study have been allocated a facies code

(figure 5.12) and interpretation based upon their individual features. This allocation

allows us to recognise the associations and successions of facies and allows

construction of a facies model for the southern segment of the Kāpiti Coast. Through

the interpretations given to these individual facies, a depositional history for each core

or outcrop site is created.

\begin{tabular}{|c|c|c|c|}
\hline $\begin{array}{l}\text { Facies } \\
\text { Code }\end{array}$ & Lithology & Identifying features & $\begin{array}{l}\text { Interpreted } \\
\text { Environment }\end{array}$ \\
\hline CG1 & $\begin{array}{l}\text { Poorly-sorted } \\
\text { conglomerate }\end{array}$ & $\begin{array}{l}\text { Angular Torlesse sandstone clasts up to } 5 \mathrm{~cm} \text {, in a } \\
\text { brown sand matrix. Some bedding visible. }\end{array}$ & $\begin{array}{l}\text { Modern } \\
\text { earthworks }\end{array}$ \\
\hline CG2 & $\begin{array}{c}\text { Sandy } \\
\text { conglomerate }\end{array}$ & $\begin{array}{l}\text { Well-rounded Torlesse sandstone clasts up to } 5 \mathrm{~cm} \text {, } \\
\text { grey sand matrix. Occasional shell hash. }\end{array}$ & Foreshore \\
\hline CG3 & $\begin{array}{c}\text { Bedded } \\
\text { conglomerate }\end{array}$ & $\begin{array}{l}\text { Dark brown. Clasts up to } 20 \mathrm{~cm} \text { in size. Brown sand } \\
\text { matrix. Laterally continuous bedding up to } 20 \mathrm{~cm} \\
\text { thick and infilled channel structures. }\end{array}$ & $\begin{array}{l}\text { Foreshore, } \\
\text { proximal to a } \\
\text { stream mouth }\end{array}$ \\
\hline S1 & Fine-sand & $\begin{array}{l}\text { Fine brown sand. Variable sorting. Roots, wood } \\
\text { pieces and other organic fibres common. Well- } \\
\text { bedded, laminated in places. Modal grainsize of 169- } \\
203 \mu \mathrm{m} \text { and a mud content of } 10-30 \%\end{array}$ & Dune \\
\hline S1V & $\begin{array}{l}\text { Fine-sand with } \\
\text { pumice }\end{array}$ & $\begin{array}{l}\text { As above. High content of white pumice, } \\
\text { occasionally banded grey. }\end{array}$ & Dune \\
\hline S2 & $\begin{array}{l}\text { Mineralogically } \\
\text { diverse, brown } \\
\text { sand }\end{array}$ & $\begin{array}{l}\text { Medium to fine brown sand. Grain mineralogy } \\
\text { includes orthoclase, amphiboles, micas and volcanic } \\
\text { material. Some horizontal bedding. }\end{array}$ & Foreshore \\
\hline LS2 & $\begin{array}{l}\text { Finely laminated } \\
\text { sand }\end{array}$ & $\begin{array}{l}\text { Light-grey, fine-sand laminated with dark-grey silty- } \\
\text { sand. Lamina up to } 10 \mathrm{~mm} \text { thick. Mud content } \\
\text { recorded as } 48.2 \% \text { (single sample). }\end{array}$ & Foreshore \\
\hline S3 & Brown sand & $\begin{array}{l}\text { Dominated by sand. Occasional well-rounded } \\
\text { Torlesse sandstone pebbles and granules. Broken } \\
\text { shell hash common. Commonly well bedded, } \\
\text { composed of grey and organic mud and wood fibres. } \\
\text { Modal grainsize of } 154-203 \mu \mathrm{m} \text { and a mud content of } \\
0-38 \% \text {. }\end{array}$ & $\begin{array}{l}\text { Upper } \\
\text { shoreface }\end{array}$ \\
\hline S4 & Grey sand & $\begin{array}{l}\text { Dominated by sand. Scattered Torlesse sandstone } \\
\text { pebbles and granules. Broken shells and hash visible } \\
\text { in places. Moderately sorted with a modal grainsize } \\
\text { of } 116-223 \mu \mathrm{m} \text { and a mud content of } 0-37 \% \text {. }\end{array}$ & Shoreface \\
\hline OG1 & $\begin{array}{c}\text { Sand with } \\
\text { organic fibres }\end{array}$ & $\begin{array}{l}\text { Brown sand with dark brown, organic pieces up to } \\
5 \mathrm{~mm} \text { long. }\end{array}$ & Foreshore \\
\hline OG2 & $\begin{array}{l}\text { Organic stained } \\
\text { sand }\end{array}$ & $\begin{array}{l}\text { Brown sand. Light/dark depending on the amount of } \\
\text { organic staining. Roots and organic fibres common. } \\
\text { Mud content up to } 37 \% \text {. }\end{array}$ & $\begin{array}{l}\text { Vegetated } \\
\text { dune/Swamp }\end{array}$ \\
\hline
\end{tabular}

Figure 5.12: The facies identified in this study, their features and interpreted

environments. 


\subsubsection{Te Pari Pari Outcrops}

These two sections are located to the south (SFT) and north (NFT) of the Fisherman's Table restaurant (figure 4.1), near the base of the Te Pari Pari cliffs (figure 4.3). The sections are of coastal outcrops, at the southern end of the Kāpiti Coastal Plain. The outcrops both contain conglomerates and sands with pumice material throughout.

\subsubsection{South Section}

The vertical facies succession for this outcrop indicates a change of depositional environment, interpreted as a change from foreshore to dune. The lowest unit of the SFT outcrop (figure 5.13) is a fine-sand with horizontal laminations and a diverse mineralogy, this is interpreted as a foreshore deposit (S2 facies). The overlying unit recognised in this outcrop is a sandy conglomerate, poorly-sorted and bedded with changes from clast to matrix supported sections as well as changes in sorting. This conglomerate is assigned the facies code of CG3, a stream mouth under the influence of shoreline processes such as wave action. The overlying unit in this outcrop is a finesand with a high percentage of small pumice pebbles within the sand. This pumaeceous sand is recognised as the S1V dune facies, and is overlain by another deposit of stream mouth conglomerate from the CG3 facies. Sitting above this are alternating beds of fine-sand and pumaeceous sand, recognised as deposits of the S1 and S1V facies respectively.

\subsubsection{North Section}

The vertical facies succession of the 10m high northern Fisherman's Table outcrop shows a record of terrestrial environmental change, from a foreshore to dune (figure 5.14). The basal unit of this outcrop is a sand with faint horizontal laminations, this has been allocated the facies of S2, a foreshore environment. Above this is a deposit of conglomerate bedded with lenses and laterally continuous beds as well as channel structures. Recognised as CG3, this facies is interpreted as a deposit of a shoreline stream mouth, influenced by fluvial and marine processes. The three units above the conglomerate are brown, fine-sands which are well-sorted and are interpreted as being deposited in a dune environment, however the lowest unit is classified as a S1V due to its pumice content. The final unit of the outcrop is also interpreted as a dune environment, however the facies code is S1V and pertains to the high percentage of pumice content within the fine-sand. 


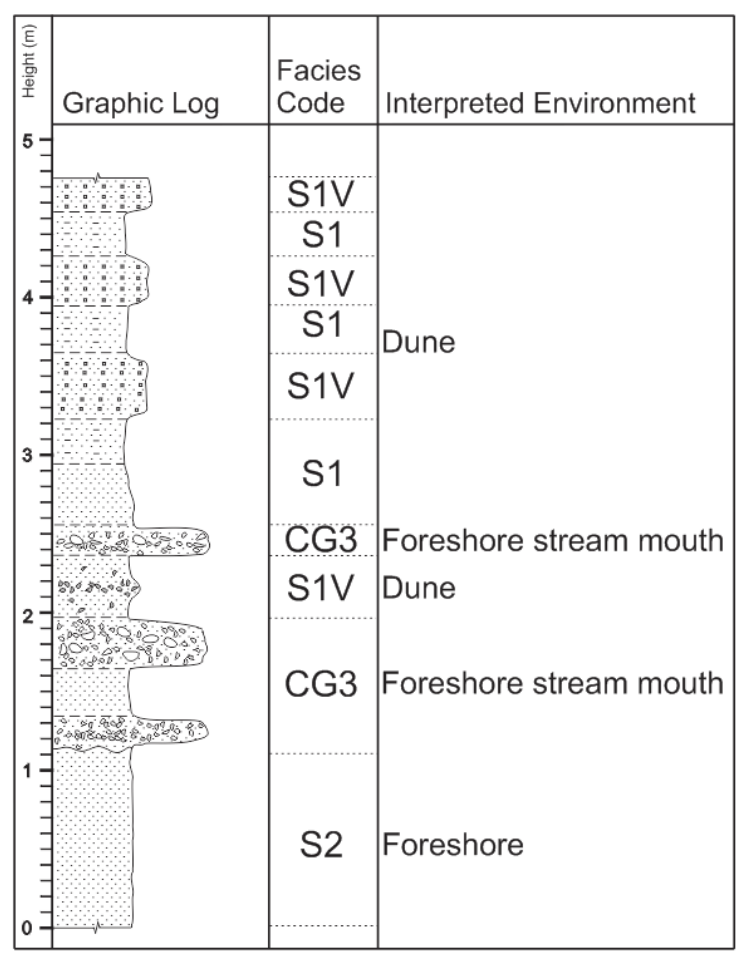

Figure 5.13: The southern Fisherman's

Table facies coding. Vertical facies succession shows a change from a foreshore environment to a dune environment with the influence of a small stream, which is indicated by the conglomerate deposits.

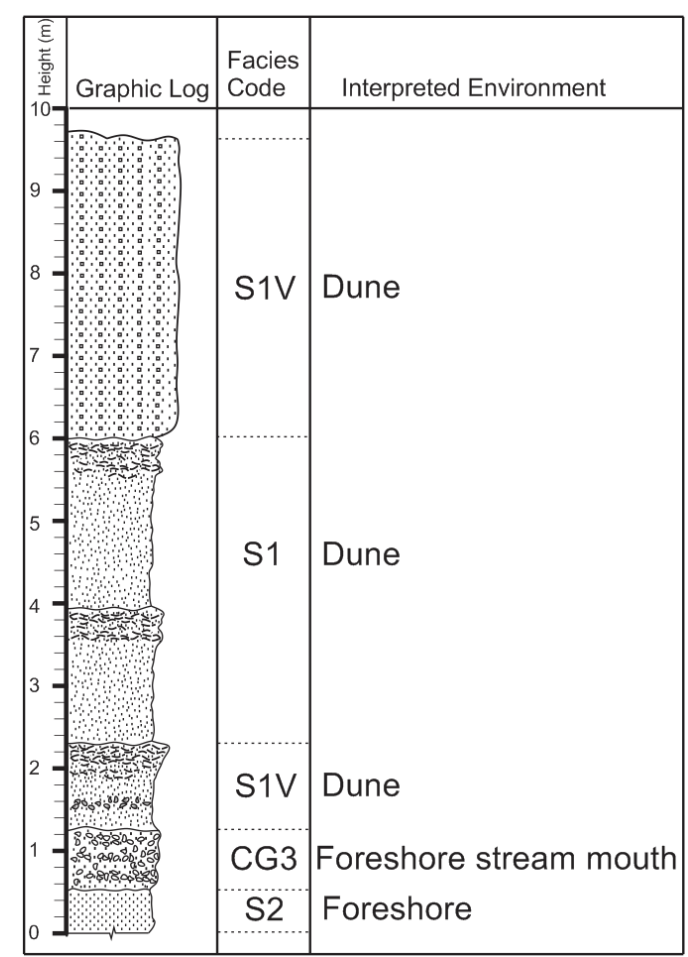

Figure 5.14: The facies coding for the northern Fisherman's Table section. The vertical facies succession shows an environmental change from foreshore to dune that is briefly disrupted by a foreshore stream mouth. 


\subsubsection{Wainui Stream}

The two Wainui Stream cores were taken proximal to the mouth of the Wainui stream on the shoreline north of the town of Paekakariki.

\subsubsection{WS1}

The basal sand unit in this core (figure 5.15) is interpreted as a S2 facies, the foreshore environment. Overlying this is an organic-rich sand deposit, recognised as an OG1 facies, also deposited in a foreshore environment. The overlying shell and sand units are coded as S2, foreshore deposits, the thickest of which features a diverse mineralogy of sand grains.

The facies in this short core is completely a foreshore record. The core is primarily sand with the organic material and shellbeds interpreted to be deposits of loose material moved across the foreshore by waves, similar to that observed on modern Kāpiti Coast beaches.

\subsubsection{WS3}

The vertical facies succession of this core shows an upward coarsening trend from shoreface to foreshore. The basal $20 \mathrm{~m}$ of this core (figure 5.16) is recognised as the S4 facies, a shoreface depositional environment. This interpretation is supported by the results of the grain size analysis on samples taken from this segment as a fine-grained sand with a mud content of up to $30 \%$. The overlying unit is recognised as the $\mathrm{S} 3$ facies, fine sand with thin organic lenses and Torlesse sandstone pebbles, interpreted as an upper shoreface environment. The diverse mineralogy of the S2 facies is seen in the overlying unit of the WS3 core, interpreted as a foreshore deposit. This unit aligns with the S2 facies at the base of the WS1 core. The top unit of the core is a poorlysorted conglomerate, composed of angular Torlesse sandstone clasts and is recognised as the CG1 facies, an anthropogenic conglomerate produced through the earthworks that established the carpark next to the stream mouth. 


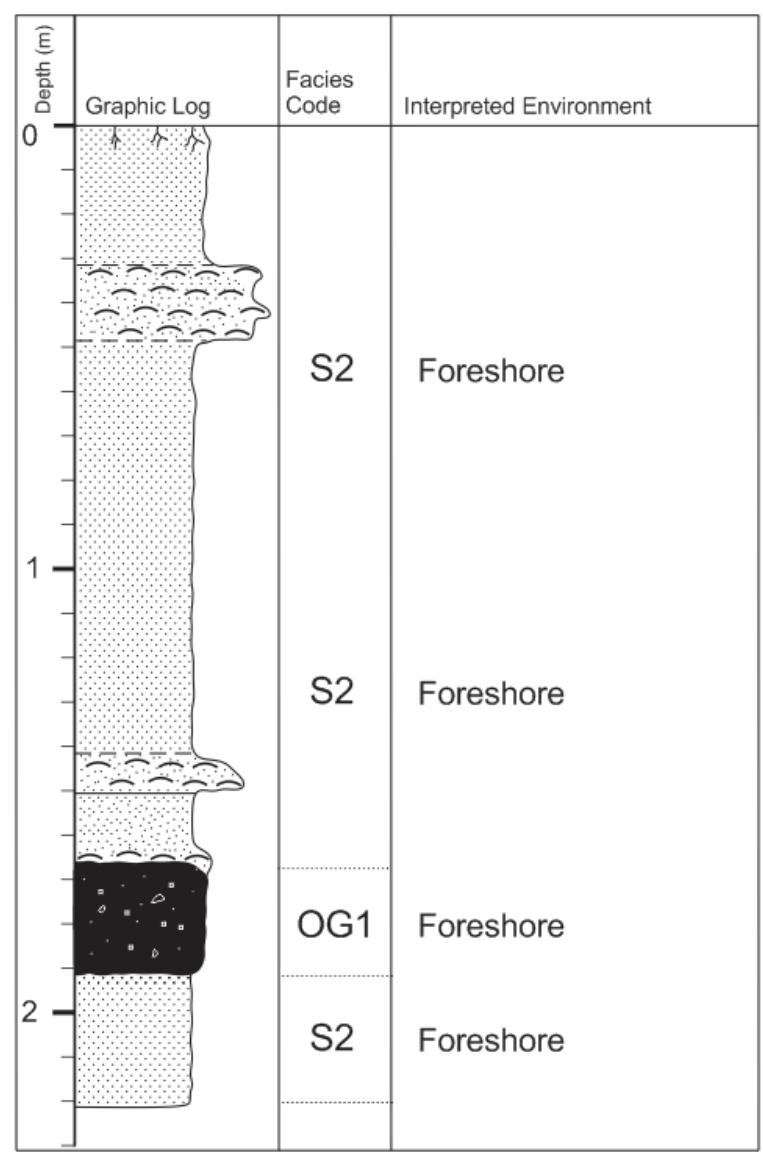

Figure 5.15: The facies coding and interpretations of the graphic log for the WS1 core. The interpreted environment for all facies in this core is a foreshore setting.

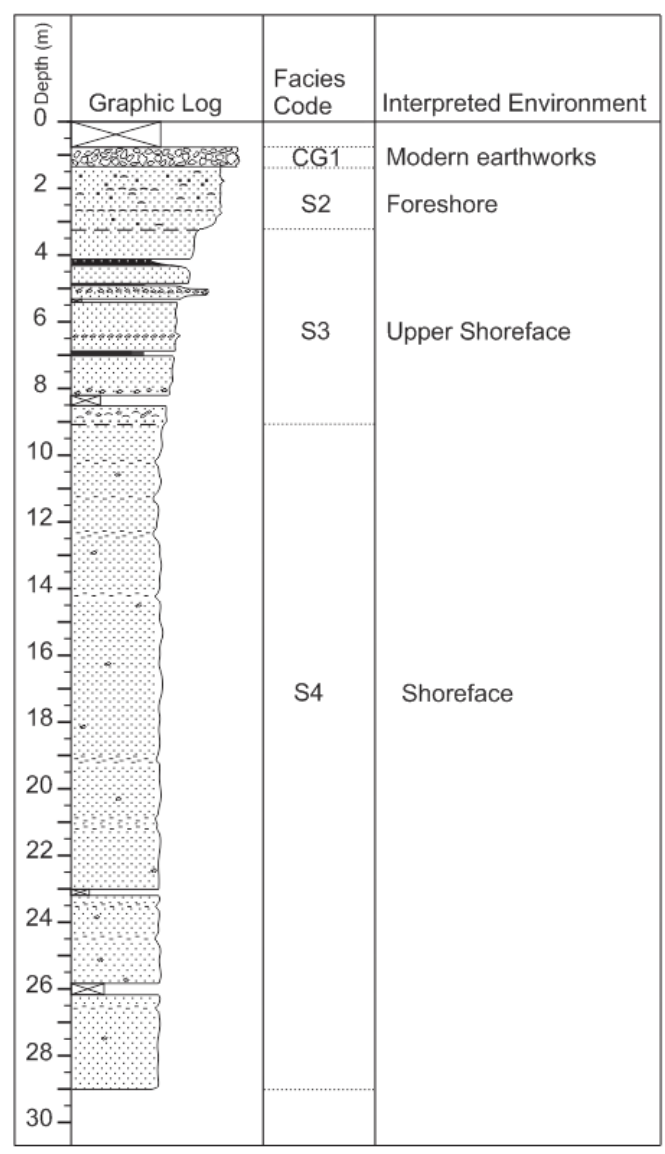

Figure 5.16: The facies coding for the WS3 core. The interpretations of the facies, demonstrate an environmental change, shallowing from the shoreface to foreshore with an anthropogenic deposit on the top. 


\subsubsection{Pickle Pot Dune Face}

Two facies have been recognised in this section (figure 5.17), and both are interpreted as a coastal dune. The lowest unit is a fine, well-sorted sand recognised as the S1 facies, a dune. Above this is the S1V pumaeceous sand with cross bedding at $30^{\circ}$, this unit is also interpreted as a dune deposit with the addition of a large amount of pumice.

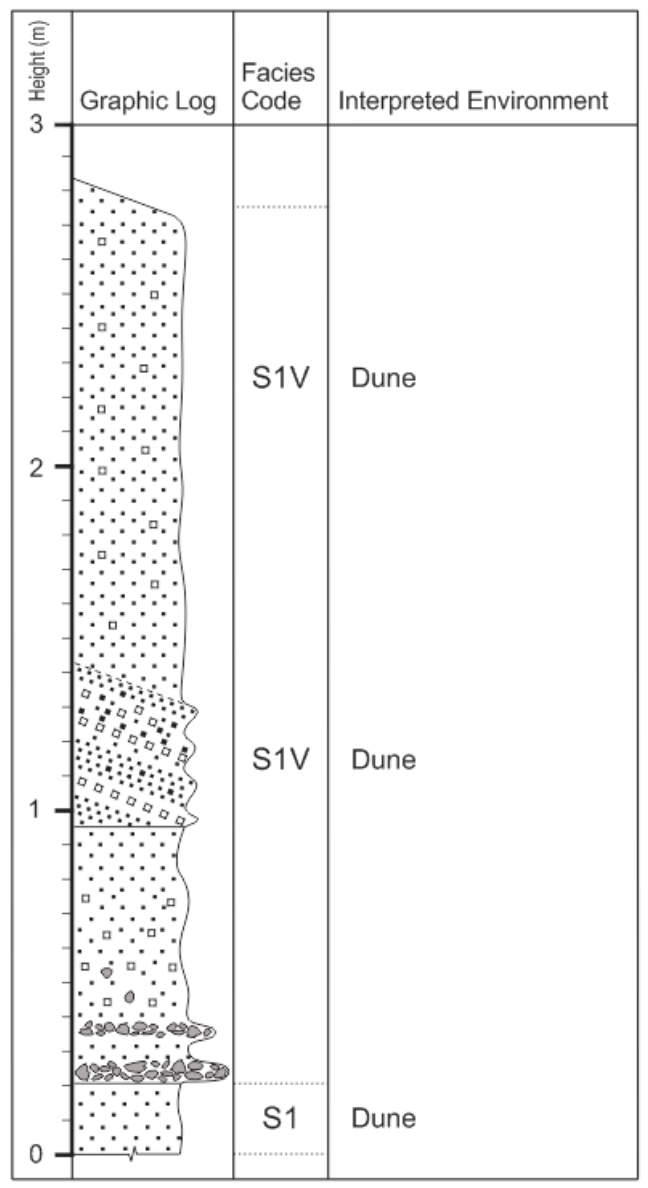

Figure 5.17: The facies coding of the Pickle Pot outcrop. The interpretations of the facies show a consistent dune environment through the deposition of this sequence. 


\subsubsection{Wharemauku Cores}

The four cores were drilled on the flat runway field at Kāpiti Airport, at an elevation of $6 \mathrm{~m}$ above sea level. The Kāpiti airport has been developed on what was once an established dune field (Wright, 1988).

\subsubsection{1 $A B 1$}

The basal unit of the $A B 1$ core (figure 5.18) is recognised as the $S 3$, upper shoreface facies. This allocation is based on the brown muddy fine-sand with laminations of mud, with shell hash and rounded pebbles indicating high energy. The overlying unit in core is a CG2 facies, a foreshore conglomerate of sub-rounded Torlesse sandstone clasts in a grey, medium-grained sand matrix. Sitting above a small segment of core loss is a laminated sand and silt of the LS2 facies (sub-facies of the S2, foreshore facies). The overlying two units are recognised as OG2 and S1 facies, both interpreted as terrestrial environments within a dune system. The organic mud content and root structures of the unit recognised as OG2 suggest a swamp environment. The top unit of this core is a CG1 facies, an anthropogenic conglomerate produced through the development of the runway.

The vertical facies succession at the AB1 core site shows an initial environmental change from upper shoreface to a foreshore. Following this the foreshore environment becomes vegetated and dune swamp is formed. Finally this dune swamp is buried by a sand dune before the CG1 conglomerate of the runway development is deposited.

\subsubsection{AB2}

The AB2 core's (figure 5.19) basal unit is a brown sand, classified as the $\mathrm{S} 3$ facies. This is interpreted as a shoreface deposit, consisting of a brown medium-fine-sand, with lenses of wood fibres amongst the sand. Above this is a unit of fine-sand, displaying a diverse mineralogy. This deposit is interpreted to be that of a foreshore sand ( $\mathrm{S} 2$ facies). A gradational contact marks the boundary into the next unit, a fine well-sorted sand, classified as a dune deposit of the S1 facies. The top units of this core are alternating sands and conglomerates, allocated as the modern earthwork CG1 facies.

The vertical facies succession of the $A B 2$ core shows a transition of environments from marine through to terrestrial. Initially an upper shoreface environment, a shallowing at the core site leads to the transition into a foreshore environment. A gradational contact marks the gradual establishment of dune overlying the foreshore. The 
interbedded sands and conglomerates in the upper $3.4 \mathrm{~m}$ of this core represent the establishment of the runway.

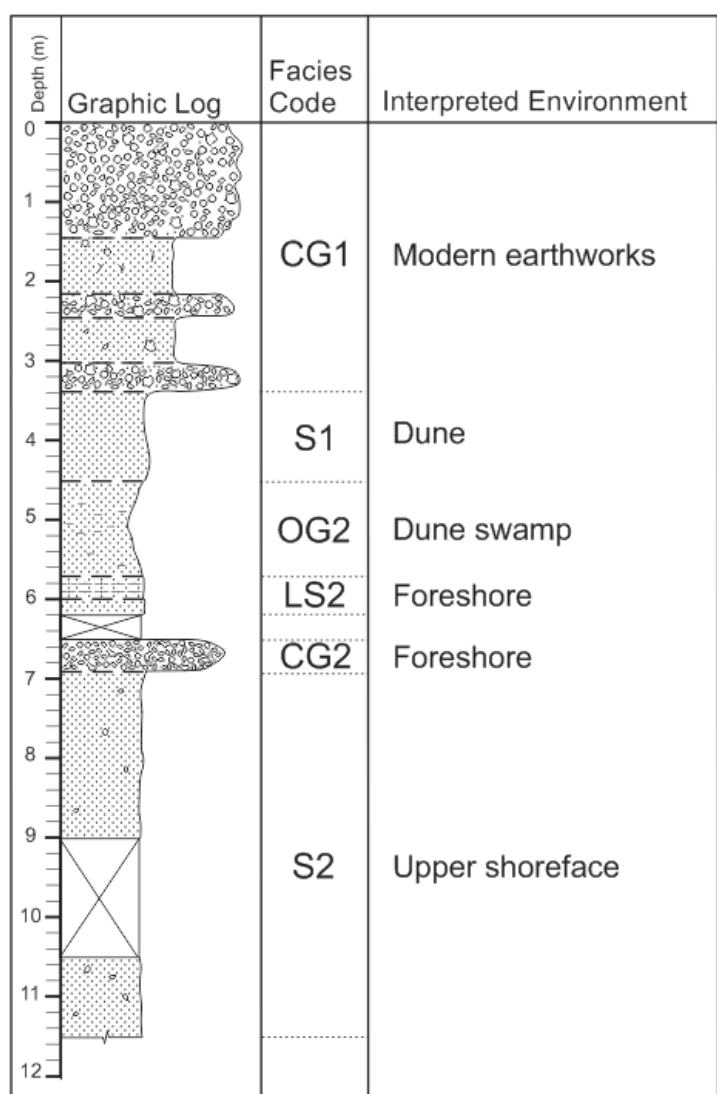

Figure 5.18: The facies coding for the AB1 core. The interpretations of these facies show an environmental change from upper shoreface to foreshore followed by a dune swamp and then dune. The top facies is recognised as anthropogenic earthworks.

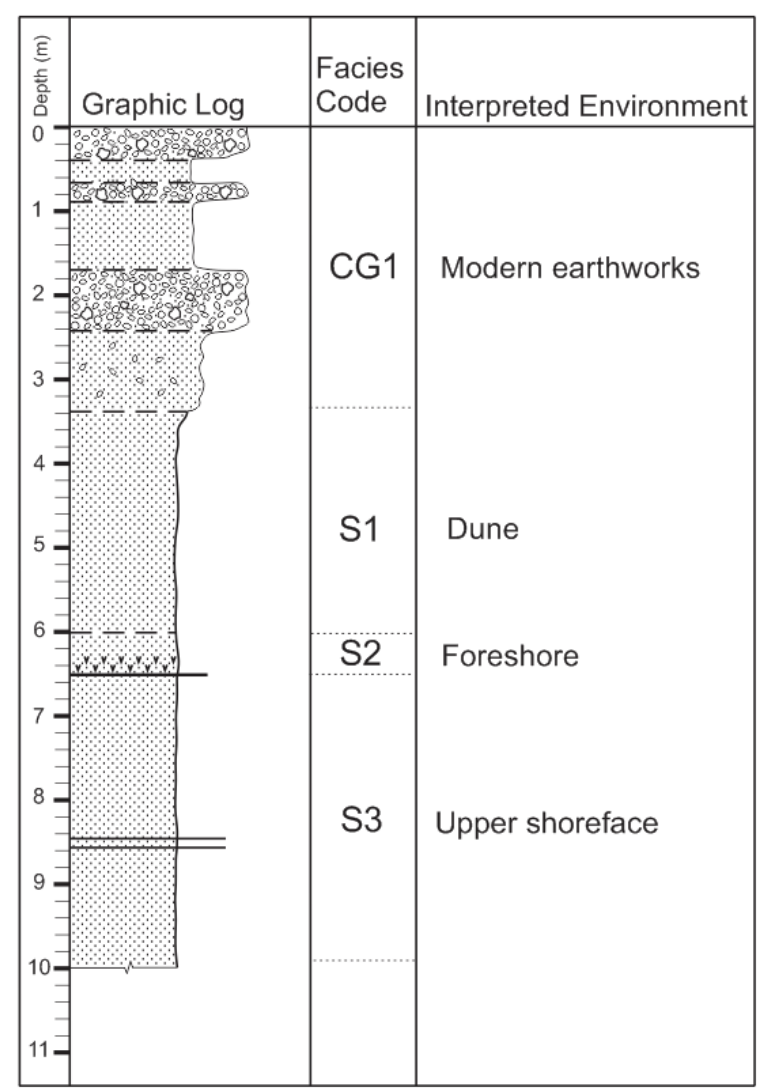

Figure 5.19: The facies coding of the AB2 core. The interpretations of these facies show an environmental transition from an upper shoreface through foreshore to dune. The top facies is recognised as anthropogenic earthworks. 


\subsubsection{3 $A B 3$}

The basal unit of the $A B 3$ core (figure 5.20) is a grey fine-sand with moderate sorting and common shell hash, classified as a S4 facies, a shoreface deposit. Overlying this shoreface deposit is a brown, bedded sand with whole Paphies subtriangulata, recognised as the S3 facies, an upper shoreface deposit. Above this unit of S3 sand is a $10 \mathrm{~cm}$ core loss. Overlying the core loss is a unit of laminated grey sand, recognised as a LS2 facies interpreted as being deposited in a foreshore environment. A sharp contact separates the LS2 deposit from the overlying massive, brown sand with a diverse mineralogy, also interpreted as a foreshore deposit (S3 facies). Overlying the unit of foreshore sand at $5.1 \mathrm{~m}$ is an organic-stained sand (OG2 facies), interpreted as the establishment of vegetation in a dune swamp environment. The uppermost sand unit is interpreted as a dune environment (S1 facies).

The vertical facies succession of the $A B 3$ core records initially a transition from shoreface to upper shoreface of the S4 and S3 facies, then a transition to foreshore environments of the LS2 and S2 facies. The gradational contact to the OG2 facies suggests a gradual development of vegetation at the core site, which is finally covered by the S1 dune facies.

\subsubsection{AB4}

The basal sand unit of the AB4 core (figure 5.21) is recognised as the S4 facies, and interpreted as shoreface sand. This is succeeded by a brown sand unit of the S3 facies, interpreted as an upper shoreface environment. The overlying unit is composed of organic fibres amongst sand, recognised as an OG1 facies it is interpreted as forming in a foreshore environment. The brown sand unit overlying this is also interpreted as a foreshore deposit (S2 facies). The overlying unit is well-sorted, fine, brown sand, this units facies is the S1 dune. The top three units of sand and Torlesse sandstone pebbles are recognised as CG1 facies, a product of modern earthworks.

The vertical facies succession of the AB4 core shows a shallowing from upper shoreface to foreshore then a transition to dune environment. The uppermost facies is interpreted as being a product of modern earthworks from the development of the airport. 


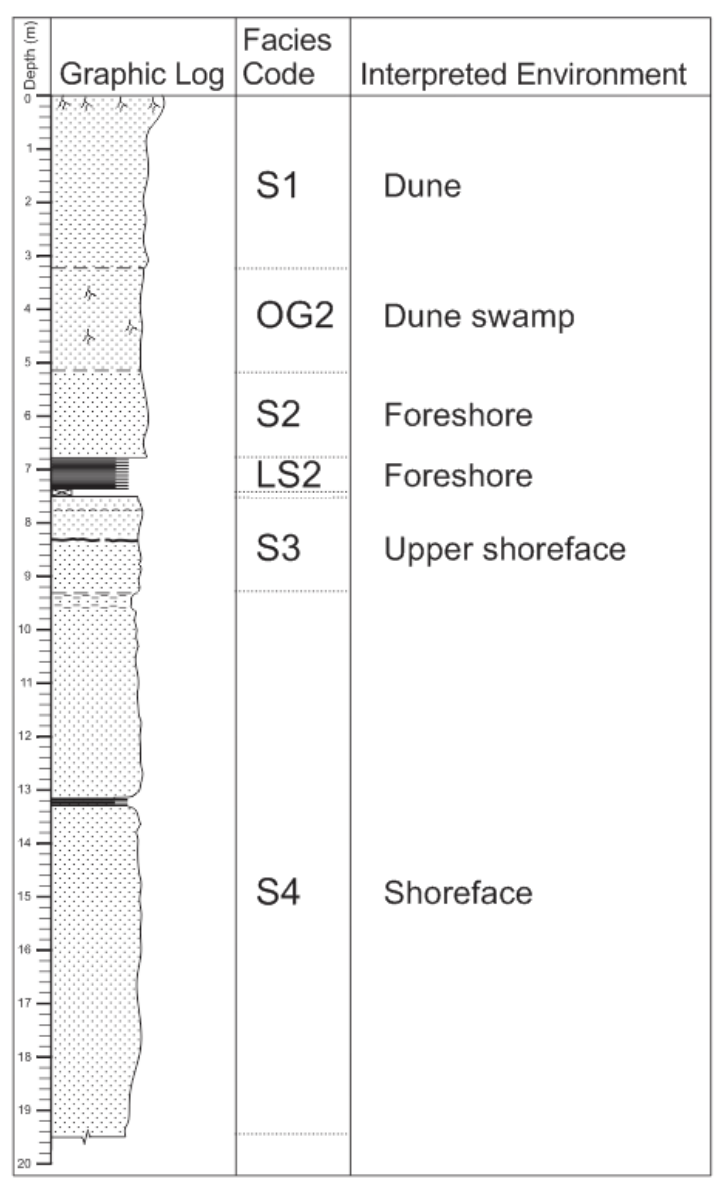

Figure 5.20: The facies coding for the AB3

core. The interpretations of the facies

shows a change in environments from

shoreface, through the upper shoreface

to foreshore. The terrestrial

environments following the foreshore

shows a change to dune swamp and then

dune environment.

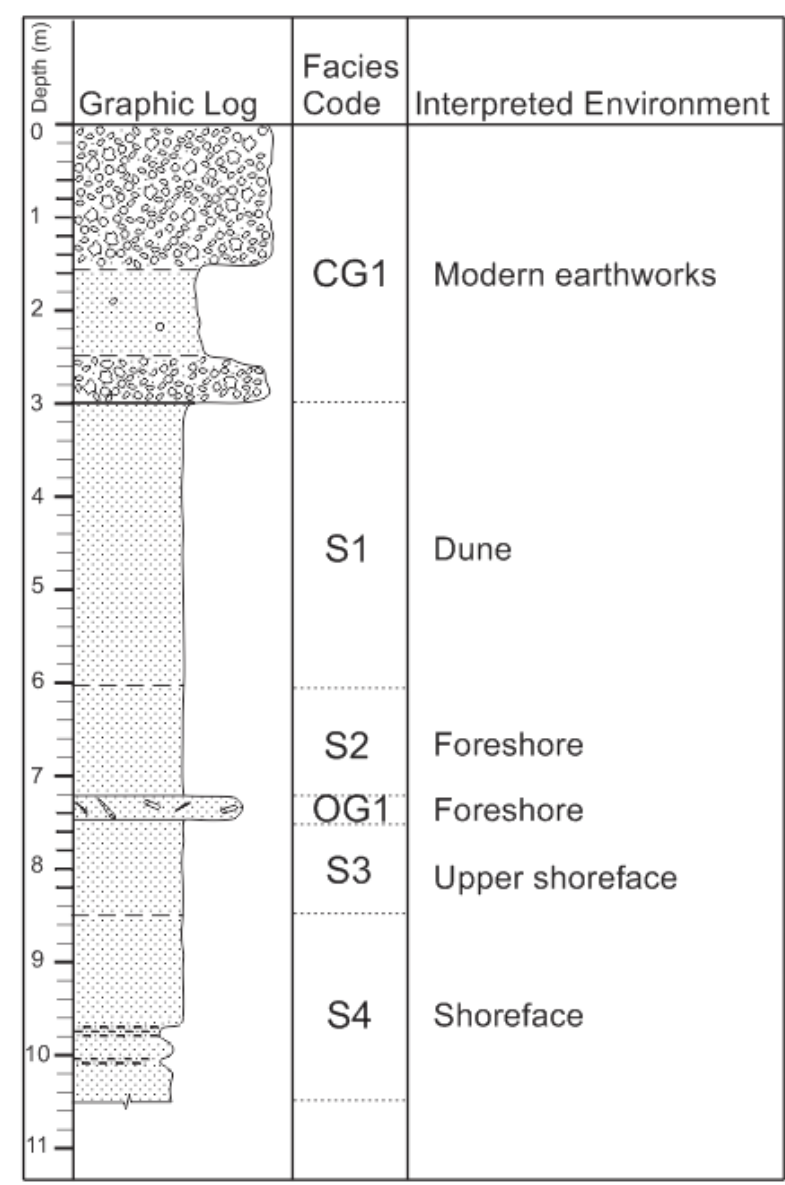

Figure 5.21: The facies coding of the AB4 core. The interpretations of these facies show an environmental change from shoreface and upper shoreface to foreshore. Above the foreshore is a dune deposit, while the top facies is recognised as anthropogenic earthworks. 


\subsection{Facies Model}

Through the allocation of lithostratigraphic units in each core and outcrop to the facies scheme, associations and successions of facies are recognised, allowing interpretations of changing environments. This section of the chapter considers the correlation of the facies and the vertical facies succession between the cores and outcrops to produce a facies model.

A facies model provides a summary of the depositional setting and allows the understanding of the succession recorded in each core and outcrop, as well as an interpretation of the depositional environment. The model demonstrates the relationships of the laterally adjacent environments and how they produce vertically stacked facies in the cores and outcrops. Due to the detail that the cores and outcrops were described in this study, some of the facies share an environment of deposition where different processes operate within the same environment, this is most prominent in the foreshore.

\subsubsection{The facies succession}

When an effective facies scheme is applied to a core or outcrop, it provides a framework for predicting the facies and depositional environments above or below a recognised facies. Each individual core or outcrop shows a particular facies succession which is used to interpret a change in environments at that location through time. The complete facies succession is not always contained in its entirety in an individual record, however the overlaps in the facies succession between cores and outcrops allows for the complete vertical succession of depositional environments to be established.

The depositional setting of the eleven facies occurring in cores and outcrops are separated into four different categories of environment: shoreface, upper shoreface, foreshore and dune (figure 5.22). These categories have been chosen as they are the four laterally adjacent environments widely recognised on prograding wave dominated coasts (Boggs, 2011). Some environments are recognised in more than one facies, this is a product of the diverse processes that operate in those environments. 


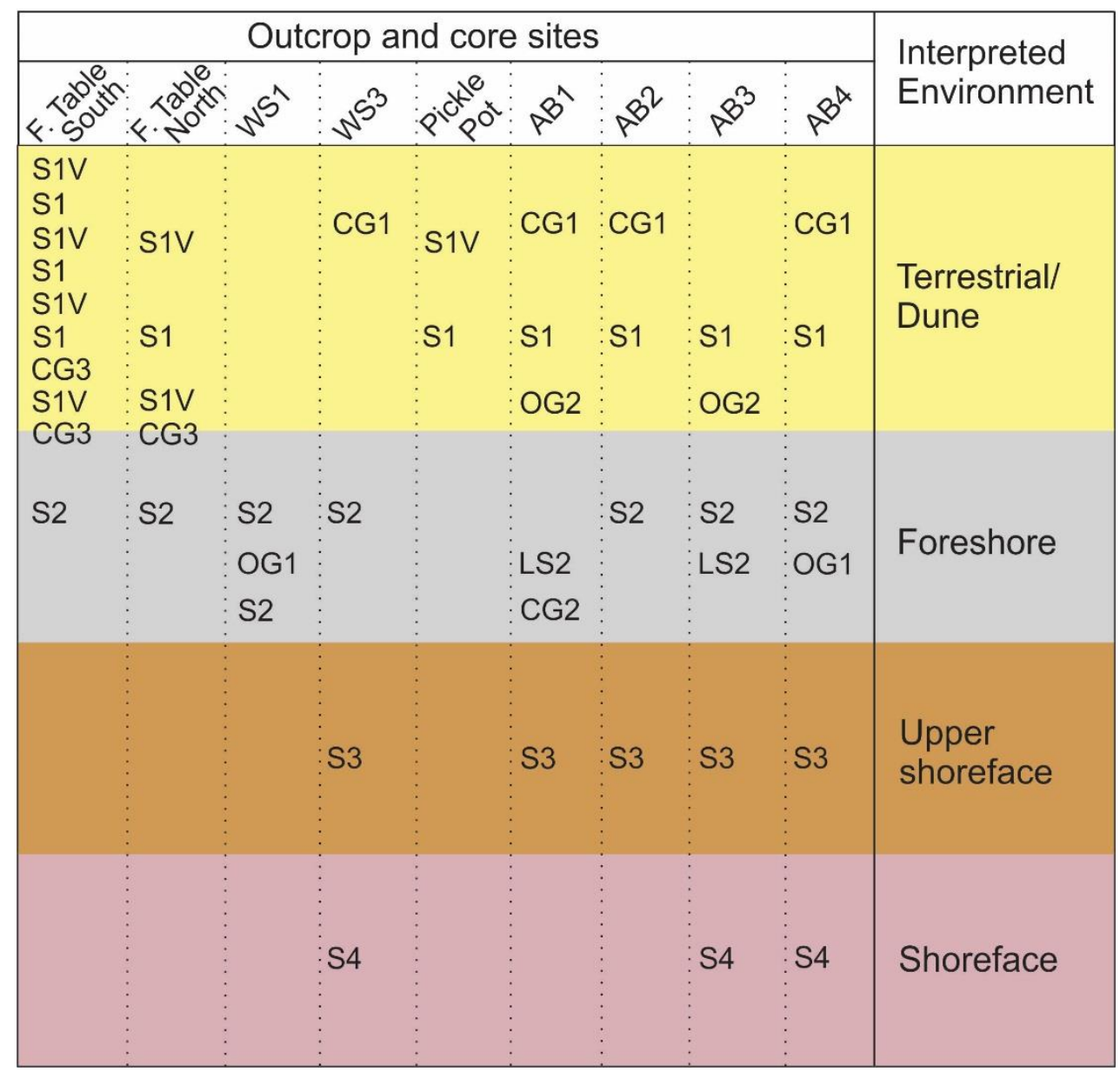

Figure 5.22: The facies successions for each core and outcrop from this study. The cores and outcrops are arranged south to north, this arrangement is purely to demonstrate the relationships between the facies across all cores and outcrops.

Where possible, codes are placed at the same height in their respective environment, this reveals the expected position that a facies may occur within an environment. The exception to this is the CG1 facies as the positions of these depend on the earthworks undertaken.

Each of the four environments recognised is classified by a primary facies, these are: dune for the S1/S1V, foreshore for the S2, upper shoreface for the S3 and shoreface for the S4. The dune and foreshore environments are further subdivided, with each containing three facies (figure 5.23). 


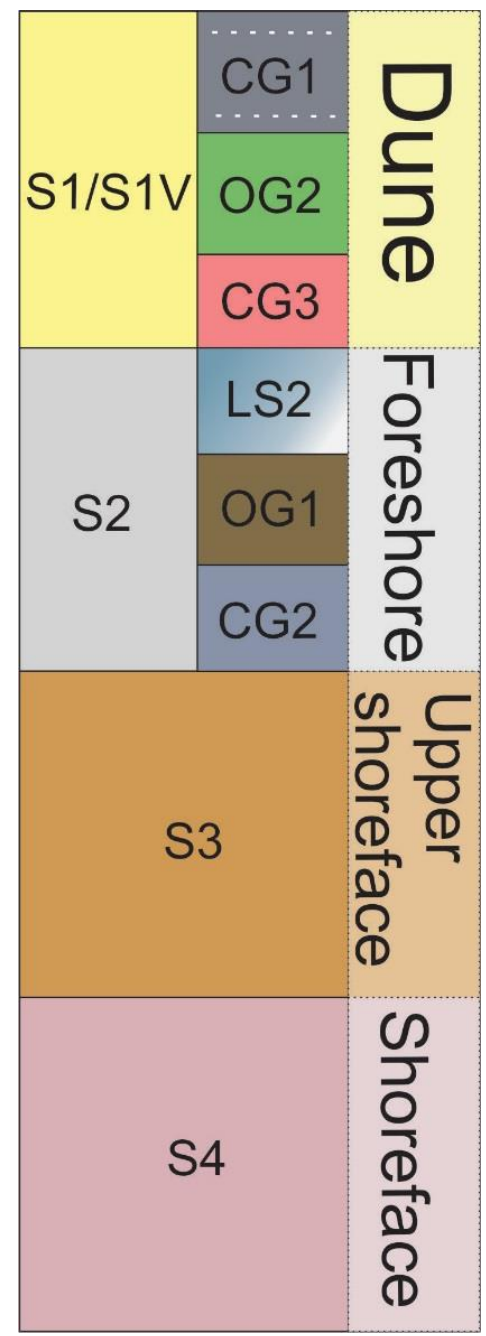

Figure 5.23: The vertical succession of the eleven facies in this study and the four environments that they are allocated to. Within the dune and foreshore environments the order of the facies relates to their position in the facies succession (figure 5.22).

\subsubsection{Depositional Model for the Southern Kāpiti Coast}

The vertical facies succession in all cores and outcrops from this study, reveal a shared vertical succession that allows for the interpretation of environmental changes through time. Combined with observations from the transect of a modern beach/dune at Waikanae Beach and using the principles of Walther's law (Middleton, 1973) the interpreted environments of these eleven facies, have been interpreted into horizontally adjacent environments. This complete facies model can be used to understand the position of a facies relative to other associated facies vertically and to adjacent environments horizontally. This model is shown as a 3 dimensional block diagram in figure 5.24 . 


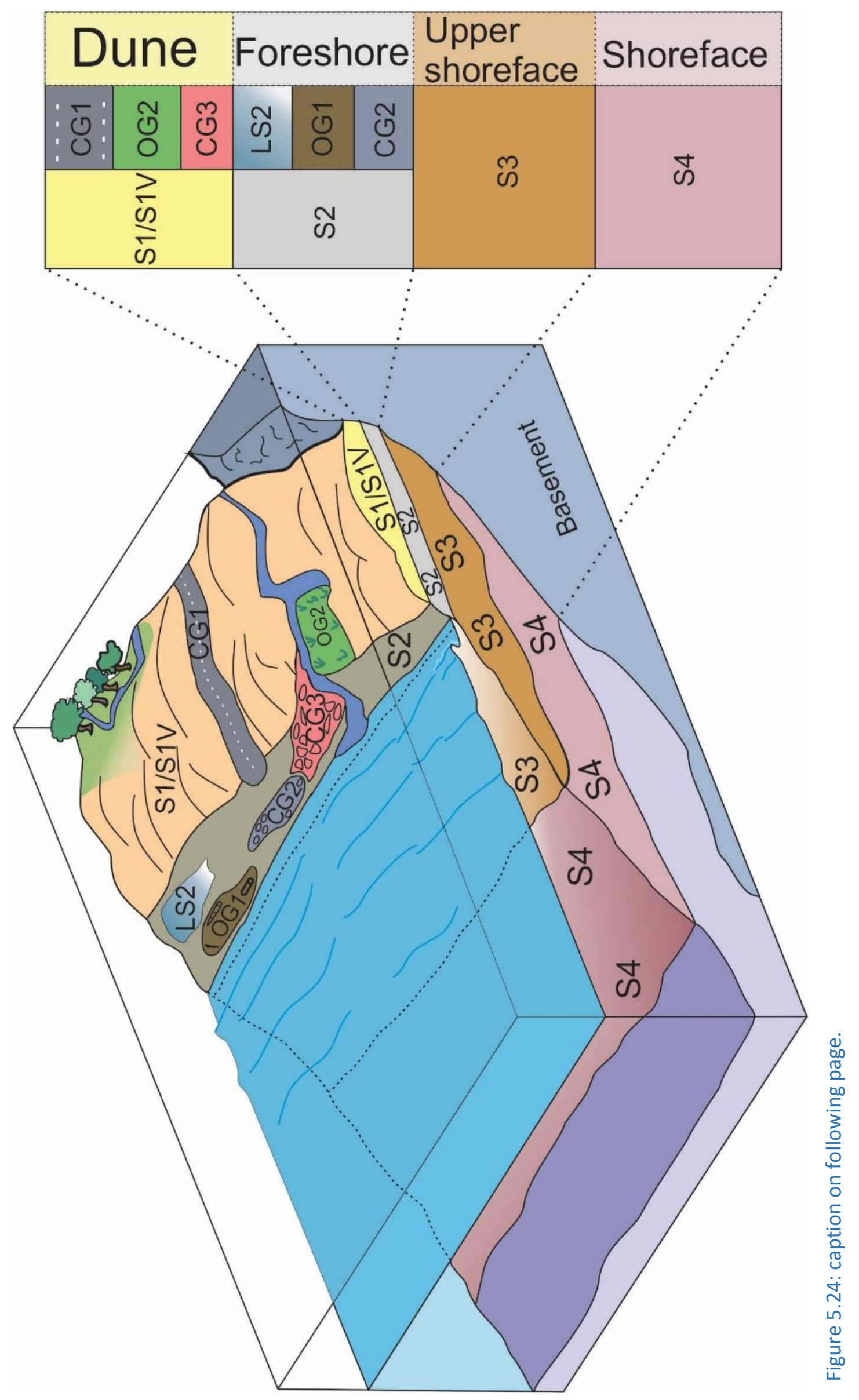


Figure 5.24 (opposing page): A depositional facies model for the southern Kāpiti Coast. The block diagram represents the horizontal relationship of the facies as represented in the vertical column (Middleton, 1973). Several facies onlap the basement unit as described at Fisherman's Table by Fleming (1965). From the work of Perrett (1990) and Dunbar and Barrett (2005), the likely existence of a finer grained facies is recognised below the identified facies, and is shown as the lowest purple facies, deposited offshore in deeper water. Although shown here, this lowest facies is uncoded as it was not encountered in this study. 


\section{Interpretation}

For the purpose of overall correlation and interpretation the cores and outcrops are grouped into three locations, The Te Pari Pari outcrops, Wainui Coastal Sites and the Wharemauku Cores. The Te Pari Pari Outcrops consists of the two Fisherman's table outcrops. The cores from Wainui Stream and the Pickle Pot outcrop make up the Wainui Coastal Sites, while the four cores taken at Kāpiti Airport comprise the Wharemauku Cores. Dividing the interpretations into these groups allows for development of the local environmental change for each area and avoids doubling up the description between similar records such as the Kāpiti Airport cores. This grouping avoids repeating the descriptions that have already been covered in the Facies Allocation section (5.2) for each individual site. In addition to this, a large amount of the justification of facies interpretation is also covered in the Facies Classification chapter (5.1).

Where possible, age control has been incorporated into the interpretations. This allows the correlation of units, facies and environmental changes through time, between individual sites and the grouped locations. In this study, pumice from welldated events, radiocarbon and optically stimulated luminescence (OSL) dating are used as age control methods. Results of grainsize and point counting from some of the samples is also interpreted. 


\subsection{Te Pari Pari Outcrops}

The Te Pari Pari Outcrops consist of the two Fisherman's Table measured sections. The outcrops are $380 \mathrm{~m}$ apart and they are named after the Te Pari Pari Cliffs immediate behind them. These outcrops occur just above the basement rock and are the southernmost geological record for the Kāpiti Coastal Plain and record a sequence of foreshore and dune development for this end of the coast, spanning a time period of nearly 4000 years. The Southern Fisherman's Table (SFT) outcrop (figure 4.5 ) is $1.8 \mathrm{~m}$ above the basement rock (Fleming, 1965) and the bedrock is visible at the shoreline adjacent to the Northern Fisherman's Table (NFT) outcrop (figure 4.8). The distance from the bedrock escarpment behind the SFT and NFT is $65 \mathrm{~m}$ and $160 \mathrm{~m}$ respectively.

\subsubsection{Environmental Interpretations}

The lowest basal unit for these two records is in the SFT and consists of a fine-sand with a diverse mineralogy and horizontal laminations. This unit was allocated the S2 foreshore facies, an interpretation supported by the horizontal laminations and bivalve fossil fragments (Clifton, 1969). The basal unit of the SFT is at an equal elevation to the basal foreshore unit of the NFT (figure 6.1). A deposit of leaves and organic material from the top of the foreshore unit at the SFT locale, was radiocarbon dated by Fleming (1965) to $5830 \pm 220$ years calBP. Using the description of the material sampled, it is interpreted as a deposit of OG2 organic material facies, drifted on a foreshore, therefore constraining the base of both outcrops to greater than 5610 years.

At both outcrops, a sharp, wavy lower contact separates the basal foreshore deposit from a sandy conglomerate, with thin laterally continuous horizontal beds. This CG3 facies conglomerate is interpreted as a stream mouth flowing onto a foreshore under the influence of waves. These deposits may be a product of synchronous deposition by two streams, or the same stream migrating laterally. The stream(s) would have flowed across the beach, depositing gravel on the sandy foreshore, a process visible at the modern stream next to the SFT (figure 5.5). As the gravel and sand deposited by the stream impeded the flow, the course of the stream would have shifted, creating small localised gravel bar deposits on the foreshore. The horizontally continuous deposits of sand and pebbles are interpreted to be a product of wave swash across the gravel bar/foreshore. The infilled channel structures, visible at the NFT outcrop, appear to be produced by the stream as it dissected the gravel bar/foreshore. The $40 \mathrm{~cm}$ thick sand 
unit between the two conglomerate units in the SFT, is part of the same depositional system because Torlesse sandstone pebbles are present, both scattered and in conglomerate lenses.

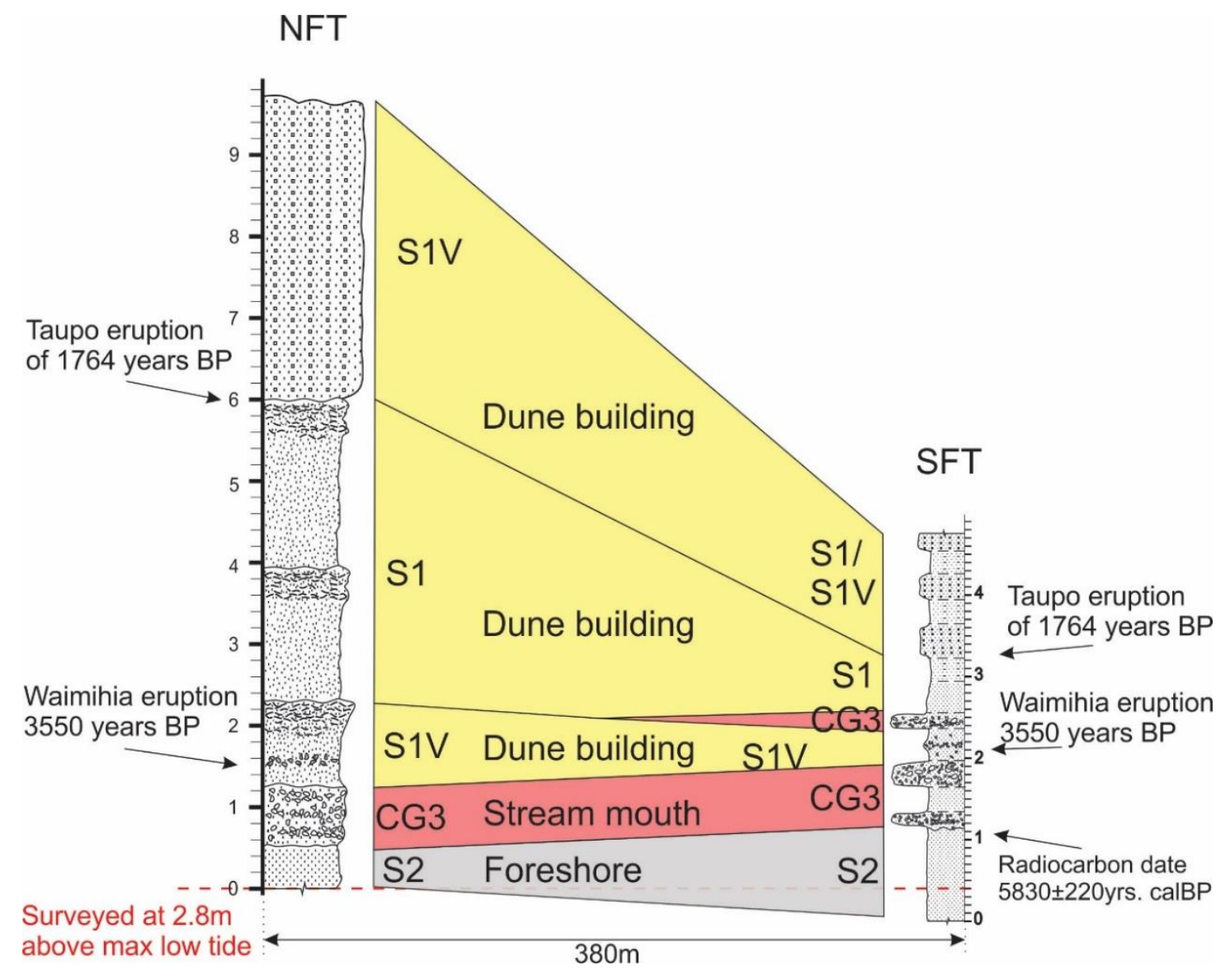

Figure 6.1: The environmental correlation of the facies succession in the NFT (Left) and SFT (right) outcrops of the Te Pari Pari Outcrops. Facies codes are listed in figure 5.12. Local tidal range is $1.9 \mathrm{~m}$ above max low tide, (LINZ, 2017a, LINZ, 2017b).

Conformably above the middle conglomerate $(2.1 \mathrm{~m})$ of the SFT is a sand with very common pumice pebbles, classified as the S1V facies this is interpreted as a dune forming with pumice material. The pumice in this unit is up to $5 \mathrm{~cm}$ in diameter, coloured a creamy white with $\sim 10 \%$ showing a distinctive grey banding. At NFT, the same sand with pumice pebbles is visible above the stream mouth (CG3 facies) conglomerate with a sharp wavy basal contact. The clasts in these deposits are wellrounded but some are broken. The grey banding in this pumice is indicative of material from the Waimihia eruption, which is from the Taupo caldera 3550 years BP (Blake et al., 1992, Wilson, 1993). This deposit in both outcrops indicates that dune deposition began around 3550 years BP. 
Overlying the conglomerate at the NFT the pumice-rich sand shows repeated beds fining up to a laminated sand. This silty-sand deposit is up to $40 \mathrm{~cm}$ thick with a dark colour. These are interpreted as soil horizons that have formed on the top of a dune once deposition as slowed (Li et al., 2007). This package of upward fining sand occurs three times in the NFT, and is interpreted as being syndepositional with the Foxton Dune Phase, a major regional dune building event from 6.5-1.5ka BP in the Manawatu (Clement et al., 2010).

In the SFT the conglomerate overlying the deposit of Waimihia pumice is interpreted as the deposition of a small local stream. This is overlain by a S1 facies dune sand, and is interpreted as being syndepositional with the Foxton dune Phase recognised in the NFT and the Manawatu (Clement et al., 2010). This deposit does not exhibit the same laterally continuous bedding in other units of this facies, this is probably a result of a local uplift event raising the unit beyond the influence of foreshore waves.

The upper unit of the NFT is a nearly $4 \mathrm{~m}$ thick deposit of light brown, fine-sand with very common pumice granules. Some of the deposit is bedded with an inland dip of $\sim 30^{\circ}$ (figure 6.2), and is interpreted to have been deposited on a lee-side dune slope (Fryberger et al., 1979, Bristow et al., 2000). This deposition suggests the pumice was concentrated on the foreshore having been deposited though ocean rafting and longshore drift (Gibb, 1978a, McFadgen, 1997, Muckersie and Shepherd, 1995) and subsequently blown into the dunes. Three pumaeceous sand units contain the pumice in the SFT and are interbedded with two silty-sands. This pumice is recognised in foreshore deposits throughout the North Island (Grant, 1985), following the Taupo plinian eruption at 1764 years BP (Wilson, 1993). These pumice deposits provide a reliable age control for these outcrops as being part of the Taupo Dune Sand, a widespread deposit through Kāpiti and the Manawatu (Cowie, 1963, Clement et al., 2010, McFadgen, 1997, Fleming, 1972).

The deposits of the Taupo Dune Sand in the SFT are considerably thinner than those of the NFT. The interpretation of a dune environment is supported by the silty-sands that are interbedded with the Taupo Dune Sand. The deposition of the Taupo Pumice granules was so widespread that the volume of ocean rafted pumice (Gibb, 1978a) available at the foreshore proximal to both outcrops would have been equivalent. Assuming that wind transport distance was the restriction to the amount of dune sand 
deposited in the outcrops, deposition of the Taupo pumice at the SFT must have occurred a greater distance from the foreshore than that of the NFT. This is interpreted as being a low vegetated area behind a foredune. This is supported by the interbedded silty-sand units, with the elevated silt content due to the ease of wind transport and its accumulation amongst the vegetation beyond the lee side of the dune. The upper silty-sand contains fragments of charcoal, the source for this is attributed to the arrival of early Maori to the area. Dating of shell and charcoal middens, proximal to the outcrop return ages of $\sim 400$ years BP (McFadgen, 1997).

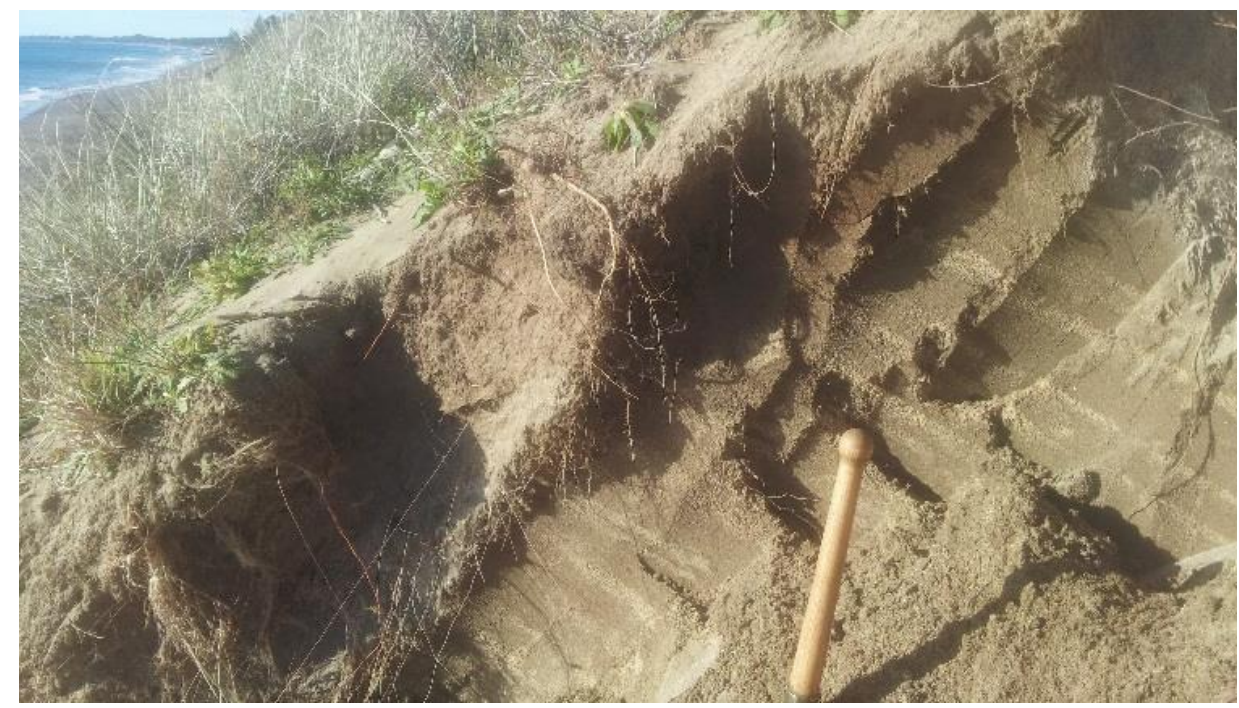

Figure 6.2: This photo displays the landward dipping beds of well-sorted white pumice grains in the S1V facies amongst brown sand at the NFT (shovel handle is $25 \mathrm{~cm}$ long, photo was taken at horizontal orientation).

Overall the interpretations of the Te Pari Pari Outcrops is a record of terrestrial environmental change with foreshore, stream and dune development at the southernmost end of the Kāpiti Coastal Plain. Initially a foreshore setting, fluvial streams from steep hills behind the outcrops have flown and migrated across the foreshore. Radiocarbon dating of organic material from the foreshore unit has returned an age of $5830 \pm 220$ years calBP. The Waimihia pumice in the units, suggests dunes began to form around 3550 years BP. Dune development continued as ocean rafted pumice from the Taupo eruption 1764 years BP arrived, with deposition slowing around the time Maori began to use the area indicated by the very shallow occurrence of charcoal. Erosion of the coastline in this area has removed a significant amount of the dune, exposing lee-side dune bedforms in the scarp of the modern beach, indicating significant retreat of the coast since the Taupo eruption 1764 years BP. 


\subsection{The Wainui Coastal Sites}

This interpretation group consists of the two cores collected near to the Wainui Stream mouth (WS1: figure 4.10, WS3 figure 4.11) as well as the Pickle Pot outcrop from 410m north (figure 4.16). These sites are located along the coastline $1 \mathrm{~km}$ and $1.5 \mathrm{~km}$ from the $6.5 \mathrm{ka}$ sea cliff respectively. The depositional environment succession recorded for this area shows a transition from the shoreface in the WS3 to a dune environment in the Pickle Pot outcrop. The Wainui stream Age control in these sites is provided by optically stimulated luminescence (OSL), radiocarbon (C14), and the first occurrence of pumice from recognised eruption events. Only the WS3 core was sampled and analysed for grainsize.

\subsubsection{Environmental Interpretations}

The basal unit in the WS3 core, is recognised as the shoreface sand facies. At $20 \mathrm{~m}$ thick this grey, silty-sand is interpreted as a shallowing column of water at the core site, driven by a constant sedimentation. The bottom $1.5 \mathrm{~m}$ of this unit is a faint brown colour, this is interpreted to be the incorporation of terrestrial sediments eroded from alluvial fans of the glacial-period by the marine transgression (Kraft, 1971). The sand in this unit is fine to very-fine, with grainsize analysis revealing a weak trend of increasing of modal grainsize and a decrease in the sorting and percent mud, interpreted to be a result of shallowing at the core site (Dunbar and Barrett, 2005). A juvenile fossil shell of a Tanea zelandica at $22.15 \mathrm{~m}$ deep in this core, is commonly found in shallow sandy bottoms around New Zealand (Beu and Raine, 2009). Juvenile fossils are reported to be a common occurrence in 10-35m water depth from Peka Peka beach (Perrett, 1990). Amongst the other broken fossils in this unit are the Paphies sp. and Dosinia sp., these specimens are well broken suggesting transport (Zuschin et al., 2003) from their recognised environment of the foreshore (Beu and Raine, 2009).

Overlying the basal shoreface unit in the WS3 core is a S3 upper shoreface facies, consisting of units 3-9. The gradational contact between these units suggests that this was a gradual change in environments, due to continued sedimentation causing a shallowing at the core site. Being within the influence of shoaling waves, the highenergy of this upper shoreface is visible in the broken condition of the shells, some identified as foreshore species (Paphies subtriangulata and the Dosinia sp. (Beu and Raine, 2009). The origin of the organic mud from units in this facies is interpreted to be 
terrestrial vegetation washed to sea by streams, like the short wood fibres which suggest transport form inland and upland sources into the upper shoreface environment.

Overlying the upper shoreface units (3-9) of the WS3 core, the next unit is a S2 foreshore sand. This unit continues the environmental trend of shallowing at the core site, interpreted from the underlying units. The high energy of this environment is evident in the poorly-sorted sand and Torlesse sandstone pebbles (McLean and Kirk, 1969).

A Evechinus chloroticus spine, found within a shellbed at $2.8 \mathrm{~m}$ deep in the WS3 core, was likely transported a substantial distance from its place of origin, as the species is commonly found on rocky shores of New Zealand (Dix, 1970). The likely source for this is the Te Pari Pari cliffs, south of Paekakariki, transported north by the longshore drift caused by southerly waves and wind (Gibb, 1978a). The spine is unlikely to have come from Kāpiti Island, the other proximal rocky shoreline, as transport would be perpendicular to current in the Rauoterangi Channel (Chiswell and Stevens, 2010, Gibb, 1978a).

The top unit of the WS3 core is a poorly-sorted angular conglomerate, interpreted as being produced from the establishment of the carpark that the core was drilled through (figure 4.12). The unit is entirely clast supported. The clasts are angular and smaller than $5 \mathrm{~cm}$, suggesting they are quarry derived road fill. The matrix of this unit is grey mud to fine-sand.

The WS1 core was collected $25 \mathrm{~m}$ south of the WS3 core and recognised as the same environment as unit 2 from the WS3 core, the foreshore. The abundance of Paphies subtriangulata shells in this core are interpreted to be vertical sections through a drift deposit of these shells on a shoreline, a common observation on the Kāpiti Coast (figure 6.3). The organic deposit in this core, recognised as the facies OG1 is interpreted to be a foreshore drift deposit (Are et al., 2003) of organic fibres in the sandy substrate (figure 5.10 ).

A composite age model for the two Wainui Stream cores combines radiocarbon dates from each core, in addition to four OSL dates from the WS3 core (figure 6.3). The sedimentation rate for this entire record was $6.7 \mathrm{~m} / 1000$ years. This rate was produced 
using the youngest and oldest dates from these cores. Using only the OSL dates from the grey shoreface sand (unit 10, blue shading in figure 6.4) the sedimentation rate for the shoreface sand was $12.6 \mathrm{~m} / 1000$ years, which demonstrates the rapid rate of sedimentation for this coastline as the shoreline prograded immediately following the stabilisation of sea level $\sim 6.5 \mathrm{ka}$ (Gibb, 1986). Using the change of lithology (green band figure 6.4) and the WS1 radiocarbon date, the sedimentation rate for the upper shoreface and foreshore environments slows to $2.7 \mathrm{~m} / 1000$ years. This decreasing sedimentation rate probably results from a deceleration in the progradation of the southern portion of the Kāpiti Coastal Plain. This deceleration is a product of the cuspate foreland reaching an extent that prevents the effective transport of sediment south of Paraparaumu Beach (Gibb, 1978a, Gibb and Depledge, 1980).

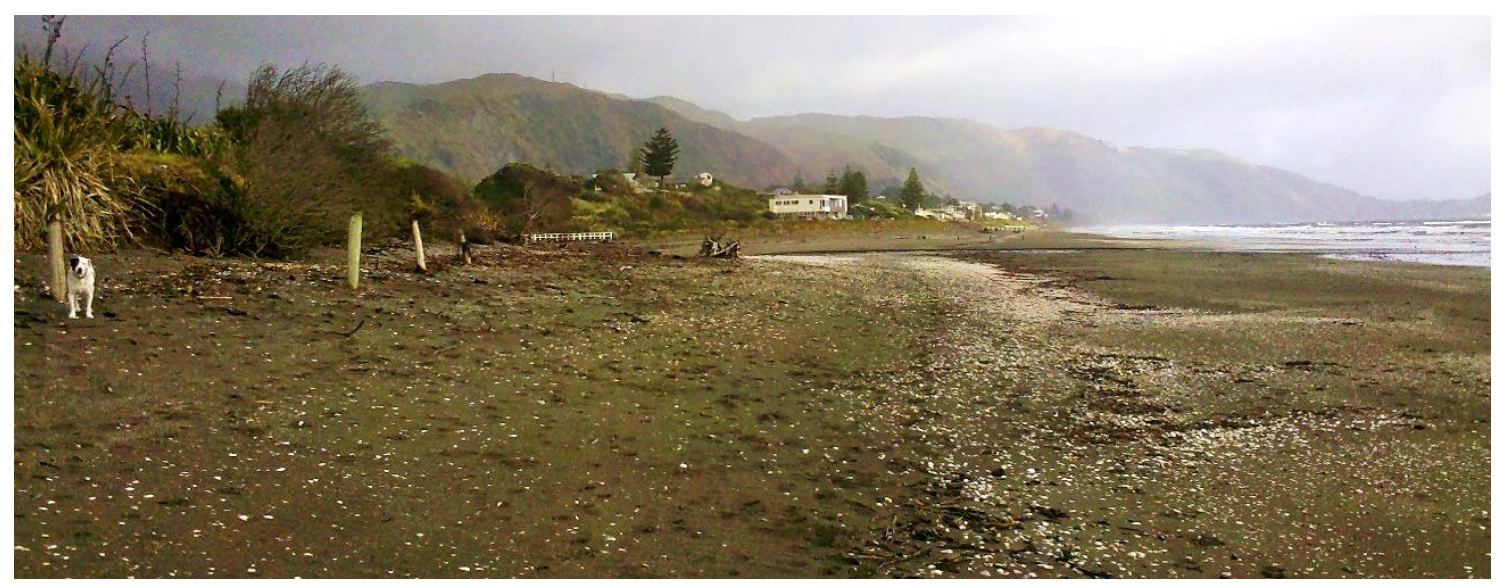

Figure 6.3: The foreshore just north of the Wainui stream, looking south towards the escarpment. Shells, wood and other organic material are visible deposited across the sand. Vertical sections through deposits of shell and organic material are interpreted in the WS1 core, similar to those seen in this photo. Dog stands $0.5 \mathrm{~m}$ high. 


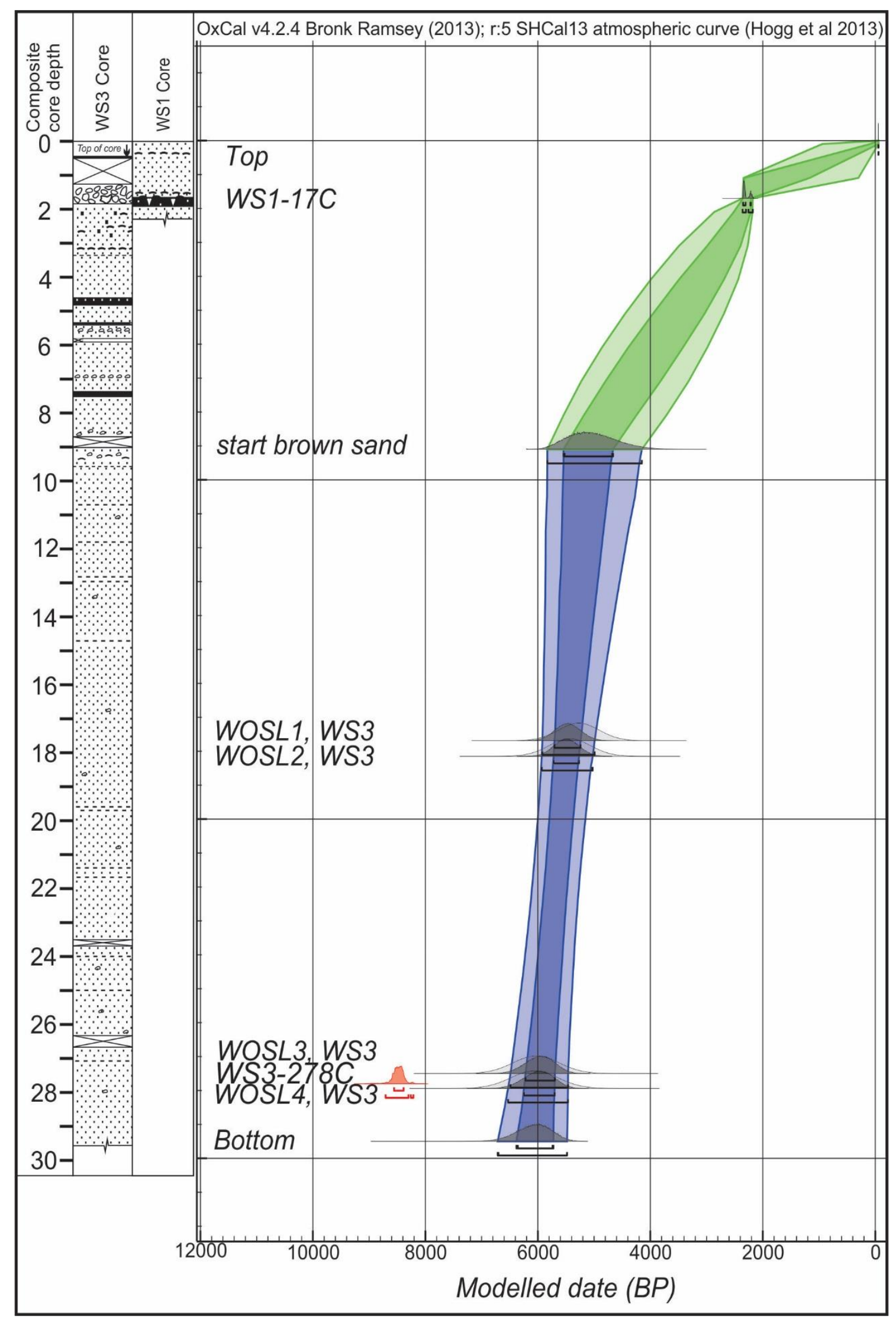

Figure 6.4: Caption on following page. 
Figure 6.4 (previous page): A composite age-depth curve for the WS1 and WS3 cores produced using OXCal v4.2.4 (Ramsey, 2009a). The graphic log of the cores is represented on the left hand side with the modelled age in calibrated years BP at the bottom. Two radiocarbon ages and four OSL dates have modelled with a variable $\mathrm{K}$ value of 100 applied to produce an Amodel of greater than 107.2 (i.e. the oldest radiocarbon date (WS3-278C), coloured in red, has been rejected as an outlier (Ramsey, 2009b) and subsequently excluded in the model. OSL dates were entered as direct model ages while the radiocarbon ages were calibrated using the SHCal13 curve (Hogg et al., 2013). The thickness of the curve is defined by 10 (dark) and 20 (light) margins of error. The lithology change from grey fine-sand to brown fine-sand is shown as a colour change from blue to green.

The Pickle Pot section consists of a record of dune development through a major eruption and is the youngest record for The Wainui Coastal Sites. All units in this outcrop are interpreted as forming in a dune environment. In addition to the environmental interpretation, this outcrop records the deposition of pumice from the Taupo 1764 years BP eruption (Wilson, 1993) at this site.

The basal unit of this outcrop is a light brown, fine, well-sorted sand interpreted as the edge of a foredune, proximal to the foreshore. Overlying this foredune edge is the lowest occurrence of pumice at this outcrop. The creamy white pumice clasts are interpreted to have been deposited on the upper bounds of a foreshore, immediately following the Taupo eruption 1764 years BP (Wilson, 1993).

A sharp contact separates the unit of pumice material from a unit of well-bedded sands, dipping southwards at $30^{\circ}$. The dip direction of these beds suggests formation on the lee-side of a dune crest, under a dominant northerly wind (Fryberger et al., 1979, Bristow et al., 2000, Boggs, 2011). This change to rear dune is probably a result of the progradation of the coast moving the foredune seawards from the outcrop. The gradational lower contact of the uppermost unit, dips $30^{\circ}$ to match the dip of the underlying unit. This upper unit is recognised as the Taupo Dune Sand with an upward decline pumice, interpreted as a diminishing supply or increased distance from the foreshore. 
The change of environments recorded in the Wainui Coastal Sites shows a shallowing as the coastline has prograded during the late Holocene. The lowest part of this record is the shoreface sands in the WS3 core, this showing a rapid sedimentation of $12.6 \mathrm{~m} / 1000$ years as the shoreline prograded. As the coast prograded the WS3 core reflects shallower upper shoreface environment with a sedimentation rate reducing to $2.8 \mathrm{~m} / 1000$ years, attributed to the growth of the cuspate foreland at Paraparaumu, limiting the transport of sediment southwards. Despite slowing, the progradation of the coast continued with the Pickle Pot outcrop through recording deposition of pumice from the Taupo eruption of 1764 years BP (Wilson, 1993). At this time the shoreline was probably seaward of the Wainui Stream core sites, as there is no recognisable Taupo Pumice material in these cores. 


\subsubsection{Grainsize Interpretations}

Samples collected from the basal unit of the WS3 core have modal grainsizes indicating fine to very-fine sand supporting the interpretation of a low energy shoreface setting. Upwards through the core the samples collected show have an $r^{2}=0.41$ (figure 4.14), with an elevated modal grainsize for the upper samples, supporting the overall interpretation of a shallowing at the core site (Dunbar and Barrett, 2005).

The sorting (standard deviation) (Folk and Ward, 1957) of the samples collected through the WS3 core show a weak trend of an increase in sorting up core (figure 4.14). There is a high degree of individual variation between adjacent samples from the core, reflected in the $r^{2}$ value of 0.30 . The weak trend in sorting through the core reflects the variability in the shear stress operating on the sea floor, driven by the Kāpiti Coast's variable wave climate (Wright, 1988).

While the interpretation for the WS3 core is of a progressive shallowing, the variable percent mud values seen upwards through the core, is at odds with the gradual decrease anticipated for shallowing records (Dunbar and Barrett, 2005). The reason may be that the rapid sedimentation rate has recorded short term fluctuations in wave energy related to storm events during the overall shallowing at the drill site due to the progradation of the shoreline.

While the up core trends for the grainsize analysis from the WS3 core shows weak trends, this in itself supports the interpretation of a wave dominated shoreface. The varied influence of wave energy on the shoreface and upper shoreface combined with the rapid accumulation of sediment, has produced variable values that have weak relationships with depth. 


\subsection{The Wharemauku Cores}

The Wharemauku Cores consist of the four Kāpiti Airport cores (figure 4.17), AB1, AB2, $A B 3$ and $A B 4$. These cores show a systematic shallowing at the core sites from shoreface to foreshore, through the transition to a dune environment and the earthworks of the runway development. There is no age control for these cores beyond contemporary record. The single radiocarbon date on a wood fragment from AB4 has been interpreted as reworked material as it returned an age that predates the Holocene $(35,849 \pm 1692$ years calBP $)$.

\subsubsection{Environmental Interpretations}

The longest record for this group is the AB3 core, which records the deepest environment for this group (figure 6.5). The basal $10 \mathrm{~m}$ of the $A B 3$ core is a grey finesand with two units of laminated mud. This basal sequence is interpreted as a low energy shoreface deposit on account of its fine grainsize and high mud percentage.

The shallowing shoreface deposit in the AB3 core is overlain by a brown sand interpreted as an upper shoreface deposit. The transition from grey shoreface sand to brown upper shoreface sand is also recorded in the AB4 core as a gradational contact. This demonstrates a gradual transition of shallowing between the two environments at both core sites. All four cores contain brown fine-sand units, of the S3 upper shoreface facies. Torlesse sandstone pebbles are interpreted to have been transported to the foreshore, by streams from the Tararua Ranges. Streams and rivers also transported the organic mud and wood fibres in these upper shoreface deposits.

The vertical facies succession of all four cores shows a transition to a foreshore environment. Units recognised as foreshore deposits in these cores include, organic deposits, sandy conglomerates, laminated sand and sand with a diverse mineralogy. Unfortunately, it is not possible to determine the timing of this transition to a foreshore environment. A single radiocarbon date on a wood chip in the AB4 core returned an age of $35,849 \pm 1692$ years calBP. The core site for this core is $2 \mathrm{~km}$ seaward of the $6.5 \mathrm{ka}$ sea cliff, where the shoreline has prograded since the stabilisation of sea level. As this date is considerably older than $6.5 \mathrm{ka}$, this wood fragment is interpreted to have been reworked from older deposits elsewhere, likely the erosion of river deposits due to the change in climate from the Pleistocene to Holocene (Vandergoes et al., 1997, Litchfield and Berryman, 2006). 


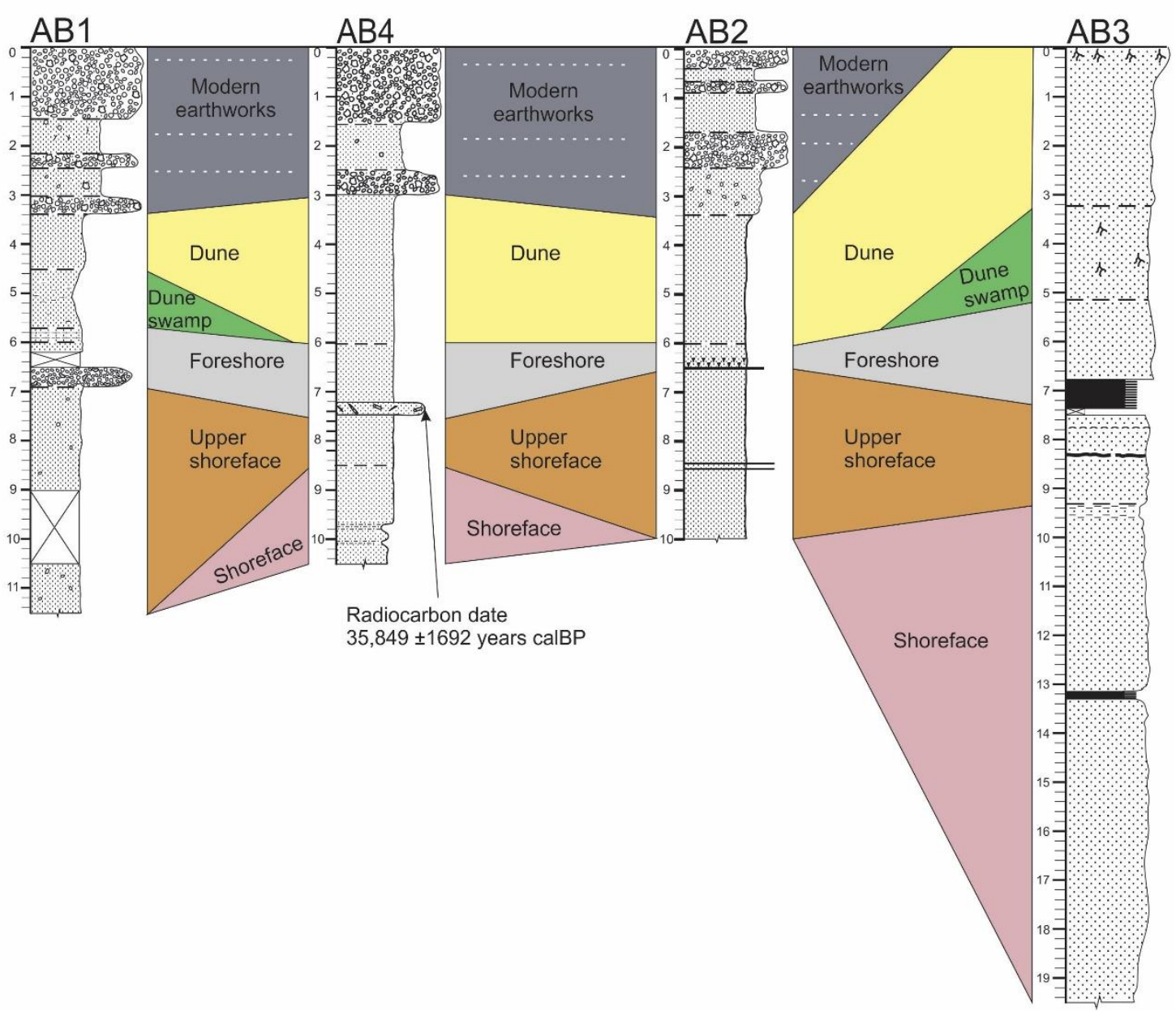

Figure 6.5: The Correlation of interpreted environments for the Wharemauku cores. Correlation has been achieved using the recognised facies from the four cores. The individual facies of the foreshore environment were grouped into their single environment due to the diversity. The terrestrial (dune/dune swamp/modern earthworks) were kept separate to show the correlation of the modern earthworks across the cores.

All four of the Wharemauku Cores show a transition to a terrestrial environment. The fine well-sorted sand in the $A B 2$ and $A B 4$ cores is interpreted as a windblown dune, with organic fragments from local plant material. A dark red/brown staining seen in the lower half of the dune unit in the $A B 2$ core is interpreted to be due to groundwater movement through the sand (Stanley et al., 2000).

The presence of groundwater is not only recognised in the $A B 2$ core, but also attributed to the units overlying the foreshore deposits of the $A B 1$ and $A B 3$ cores. Fine-sand containing organic mud and wood fibres is interpreted to be due to increased vegetation, brought on by the establishment of back dune swamps. This 
back dune swamp environment is a common occurrence on prograding sedimentary shorelines, such as the Kāpiti Coast (figure 5.11) due to the impeded drainage of waterways (Reinson, 1979), probably related to the local Wharemauku Stream. Overlying the back dune swamp facies of the $A B 1$ and $A B 3$ cores is a light brown, finesand, similar to the units seen in the $A B 2$ and $A B 4$ cores overlying the foreshore environment. These units are also interpreted as a dune deposit with gradational basal contacts suggesting the dune was a proximal environment that has encroached upon the swamp (Middleton, 1973). The sand dunes encroachment over the swamp may have been synchronous with its burial of the foreshore environment in the $A B 2$ and AB4 cores. The timing for the swamp burial by the dune is unavailable without reliable age control. Material from the 1764 BP Taupo eruption, was widely distributed throughout Kāpiti and New Zealand (Muckersie and Shepherd, 1995, Cowie, 1963, Packard, 1957), its absence suggests that the deposition of these cores predates this eruption and deposits of pumice seaward of the core sites support this (Gibb, 1978a).

The uppermost units of the $A B 1, A B 2$ and $A B 4$ cores interbedded conglomerates of angular Torlesse sandstone and sand units containing similar clasts. These are attributed to the development of the Kāpiti Airport either on or after 1939 (Ewing and Macpherson, 1986). In the AB3 core, the uppermost unit is a continuation of the light brown sand, interpreted as a dune deposit, the potential for the reworking of this deposit through the construction of the airport is acknowledged.

The Wharemauku cores show a shallowing across all cores. The lowest recognised facies is the $\mathrm{S} 4$ shoreface in two of the cores, this is succeeded by upper shoreface sand units and then overlain by foreshore deposits in all four cores. The transition to a terrestrial environment, occurs as overlying dune deposits in two of the cores. While the other two of the cores show transitions from foreshore to a back dune swamp, before finally being buried by a dune. The construction of the airport in 1939 is attributed to the conglomerates and sand at the top of the $A B 1, A B 2$ and $A B 4$ cores. 


\subsubsection{Interpretations of Grainsize and Point Counting}

This study finds that there is no consistent environmentally driven interpretations

discernible from the values of mineralogy and roundness for the Wharemauku Cores.

Grainsize however reveals some trends that are interpreted to be related to

environmental influence.

Some interpretations of environmental influences are possible, however these are not consistent across all samples or cores. The consistency of the samples across all cores and categories analysed suggests that the source of sand for these cores remained consistent with no extreme variations to the values analysed. The rapid progradation of the coast may also be a factor, where deposition exceeds a rate that preferential sorting can operate successfully at. 


\section{Discussion}

\subsection{The Kāpiti Coast's Sediment Supply}

The well-sorted sediments in the Waikanae transect (figure 4.24) demonstrates the existence of a southward longshore transport sorting the sediment as it moves towards the south (Gibb, 1978a). This has produced the positive sediment budget and rapid progradation of the coastal plain since $6.5 \mathrm{ka}$. Analysis of this sediment from the cores and outcrops of this study, demonstrate the dominant fine grained sand that composes the majority of this coastal plain. This fine sand has made it difficult to use grainsize characteristics to distinguish between depositional environments, both in the cores and outcrops and also the modern transect at Waikanae Beach.

Analysis for mineralogical composition and roundness from the Wharemauku Cores also demonstrated the consistency of the sediment deposited in this area. Upon comparison, the average roundness of the modern transect was greater than that of the Wharemauku cores, suggesting an evolution to rounder sediment on the Kāpiti Coast.

A fossil observed in the WS3 core, is the first documented evidence of a minor northward longshore drift prior to contemporary record (Gibb, 1978a). A spine of the rocky coast dwelling Evechinus chloroticus (Dix, 1970) was found in a shellbed of the WS3 core, the likely source of this spine is the base of the Te Pari Pari cliffs, transported north through longshore drift. Using the age model of the Wainui Stream cores (figure 6.4), this spine is interpreted to have been deposited prior to $2330 \pm 30$ calBP. The northward supply of this spine supports the existence of this longshore drift as a distribution method for eroded sediment from the base of the Te Pari Pari cliffs, and driven by southerly wind and waves. 


\subsection{The Beach/Dune Boundary}

The Waikanae Beach transect was carried out to document the beach and dune sediment environments and assist in developing the facies model. The site was chosen to be a modern analogue for the cores and outcrops. A primary aim of this transect was to test whether a measureable difference in the roundness and composition of samples from the beach and dune environments. Despite detailed grainsize and point counting analysis, no discernible difference was recognised in the transect, or in the cores where grain roundness and composition was measured.

This value was measured in an attempt to provide a way of distinguishing between beach and dune sediments in the facies study. The difference in roundness of the sand from these two environments has been recognised in previous studies (Beal and Shepard, 1956, Russell, 1939, MacCarthy, 1935). This application was further developed for samples in the $125-250 \mu \mathrm{m}$ size fraction by Shepard and Young (1961), this study used data from 74 beaches and was successfully applied to sediment cores taken through the beach/dune boundary of barrier island systems.

The roundness of the sand grains from the Waikanae Beach transect was used to test whether Shepherd and Young's (1961) hypothesis of rounder sand grains in the dune is applicable to the Kāpiti Coast. This test assumed the depositional processes applying to the foreshore at Waikanae beach are the same as the conditions in which the Wharemauku cores were deposited in. The overall result from both data sets was that there is no visible trend. While the TS1 sample from the back dune of the Waikanae Beach transect (figure 4.23) showed an elevated roundness value (3.65), this sample was ignored as no active deposition was occurring at this location. The roundness difference between beach and dune sands recognised by Shepard and Young (1961) does not occur in this study and as a result cannot be used to determine depositional setting.

Comparing the average of the modern roundness values (3.45) to that of the Wharemauku cores (3.29), the modern samples are typically rounder. Similar to the increase in quartz seen in the modern samples, this may be a sign of a more evolved sediment supply to the Kāpiti Coast. 
Grain roundness was unable to be used to distinguish between dune and beach sands in this study. The identification of this boundary through variations in roundness and other characteristics, may prove to be a valuable method for identifying uplift or subsidence events in coastal sediments. There are factors that must be considered for it to be used. The process of measuring grain roundness through point counting is labour intensive, Shepard and Young (1961) compared a single sample from each environment.

As demonstrated in the Wharemauku Cores (figure 6.5), the boundary between the beach and dune environments may not be at an equivalent elevation in localised records, a complication that is due to variations in foreshore/foredune environments. Localised deposition of material on the foredune is visible in the Waikanae Beach transect (figure 4.23). regional convolution of the boundary between these two environments may also be a product of coastal inundation by storms or tsunami events (Goff et al., 2007, Morton et al., 2007). 


\subsection{Facies Identification and Differentiation}

Throughout this study, the allocation of facies has relied on the sedimentological and fossil characteristics of particular units to interpret the boundary between environments. Due to the dominance of sand, overlapping processes within different facies, boundaries have been challenging to recognise. An assessment of some of the difficulties surrounding the facies scheme of this study are discussed.

The process of allocating lithostratigraphic units to facies in this study has allowed the reconstruction of environmental change for the southern limb of the Kāpiti Coastal Plain. This process however is based upon unit observations in a dynamic coastal environment. In the case of the shoreface (S4) and upper shoreface (S3), both facies are marine deposits with bedding, the separation of these two units is primarily based on a colour change from grey (S4) to brown (S3), in addition to the S3 having a narrower grainsize occurrence than the $\mathrm{S4}$ (figure 5.12). This variance is evident in the Wharemauku Cores (figure 6.5), where the boundary occurs at a range of depths from 8.5-11.5m. The time of transition from shoreface to upper shoreface is not known across all four cores and this $3 \mathrm{~m}$ variability is anticipated to be a result of local changes in sedimentation, due to changes in sediment supply or local wave climate.

The lack of sedimentary structures within the sand of the shoreface and upper shoreface deposits from this study, may be a product of the homogenous grainsize of the Kāpiti Coast's sand supply (as discussed in section 7.1). The consistent grainsize of the sand being deposited on the shoreface prevents the development of sedimentary structures that are typically used in other facies studies to identify this environment.

The overwhelmingly rapid sediment supply of predominantly well-sorted fine-sand to the Kāpiti coast, prevents the formation of sedimentary structures typically seen on a prograding sedimentary coastline (Boggs, 2011). Nevertheless the combination of observation, sedimentary characteristics and fossils allowed the identification of facies and the environmental interpretations, to produce a detailed, bespoke facies model for the southern Kāpiti Coastal Plain. 


\subsection{Methods of Age Control}

This study has employed the use of optically stimulated luminescence dating (OSL), radiocarbon dating and the stratigraphic position of pumice from well-constrained eruption events to interpret age of units. The potential for material to be reworked in a dynamic system like the Kāpiti Coast, impacts the reliability of radiocarbon for accurate constraining of environmental change, as seen in the WS3 and AB4 cores (figures $6.4 \& 6.5$ ).

Due to the southward longshore drift and its floating ability, pumice from the various eruptions of Taupo is a reliable indicator of age where available. Present as individual beds or regional dune deposits, the first occurrence of pumice is a cost effective way of interpreting the age of sedimentary sequences in this setting.

Used to constrain the sedimentation of the WS3 core (figure 6.4), OSL dating has proved the most effective way to date sediment in this setting. The abundance of datable material (sand) and its potential to be used in terrestrial and marine environments, demonstrate its wide range of application. The greatest limitation of OSL dating is that the sample must not be exposed to light. Sediment movement of sand in the darkness of the seafloor means OSL dating is not immune to the complications of reworking, however due to the rapid progradation of the coast, the assumption that sediment was not reworked was made. 


\subsection{Late Holocene Evolution of the Southern Kāpiti Coastal Plain}

Combing the interpretations of the cores and outcrops from this study with the age control, the sedimentation and progradation of the southern Kāpiti Coast can be reconstructed through the sites in this study. Each outcrop and core from this study has a succession of facies that relates to coastal progradation and sedimentation at that site. At some sites, the effects of erosion are also visible. Using the $6.5 \mathrm{ka}$ sea cliff as the landward limit (figure 7.1), the interpreted progradation of the shoreline's position through the last $6.5 \mathrm{ka}$ can be reconstructed. Relating available age control in the cores and outcrops to the depositional model of a prograding coast, interpretations of the shoreline position can be determined along this southern portion of the coast.

At 6.5ka global sea level stabilised and was close to present day levels (figure 2.7). The stabilisation of sea level began a process of erosion, creating the $6.5 \mathrm{ka}$ sea cliff. The reversal of this process was caused by deposition against the cliff through longshore drift as the progradation of the coastline began. Following the development of a sandy foreshore at the southernmost end of the Kāpiti Coastal Plain, the migration of a small stream from the base of the Te Pari Pari cliffs across this foreshore is dated with a radiocarbon date at the SFT. This radiocarbon date returned an age of $5830 \pm 220$ years calBP (Fleming, 1965) on loose material between the foreshore sand and the stream conglomerate. The development of dunes for this southern limb of the coast is recognised with the occurrence of pumice from the Waimihia eruption 3550 years BP (Wilson, 1993). This coastal progradation is synchronous with the Foxton Dune Phase of the Kāpiti and Manawatu Coasts (Clement et al., 2010, Wright, 1988), suggesting that the development of dunes was widespread along the length of the Kāpiti and Manawatu Coasts at this time.

During the establishment of dunes against the $6.5 \mathrm{ka}$ sea cliff, the progradation of the shoreline towards the Wainui Stream core sites began, indicated by the rapid shallowing in the WS3 core (figure 7.1). The deceleration of the sedimentation rate in the WS3 core around 5000 years BP, is interpreted to be a response to a decline in sediment due to the formation of the cuspate foreland at Parapraumu, preventing southward transport. An age constraint of the arrival of the shoreline at the Wainui Stream site is constrained by a radiocarbon date of material in a foreshore deposit 
from the WS1 core (figure 6.4). This dates the shoreline at this location to $2330 \pm 30$ calBP.

The volume of material erupted during the Taupo eruption of 1764 calBP was in excess of $30 \mathrm{~km}^{3}$ (Wilson, 1993), this material was widely distributed around the North Island of New Zealand (Grant, 1985). The shoreline deposit of this material was mapped throughout the Kāpiti Coast (figure 7.1) (Gibb, 1978a), and runs through the Pickle Pot section, confirming that this site was proximal to the shoreline at the time of the eruption while the absence of pumice in the Wainui Stream cores suggest that the shoreline was beyond these core sites.

The Wharemauku cores show an interpreted shallowing record from shoreface to foreshore, followed by the migration of dune swamps and dunes across the core sites, however no usable age control is available for these cores. The position of Gibb's (1978a) shoreline (figure 7.1) is beyond the site of the Wharemauku Cores, suggesting that the organically deposited units in the cores were deposited prior to this eruption. The radiocarbon date in the $A B 4$ core is ignored in this reconstruction due to its preHolocene age.

Since the recent eruption of Taupo, the shoreline of the southern Kāpiti Coast has entered an erosional cycle, evident in the scarping of the dunes along the coastline (figures 4.4, $4.7 \& 4.15$ ). The interpretation of lee-side dune formations containing pumice from the 1764 years BP eruption (Wilson, 1993) in the Pickle Pot and NFT outcrops suggests the continued deposition through this period. The erosion of the shoreline is interpreted to have begun shortly after the deposition of shallow charcoal deposits at the SFT $\sim 400$ years ago. 


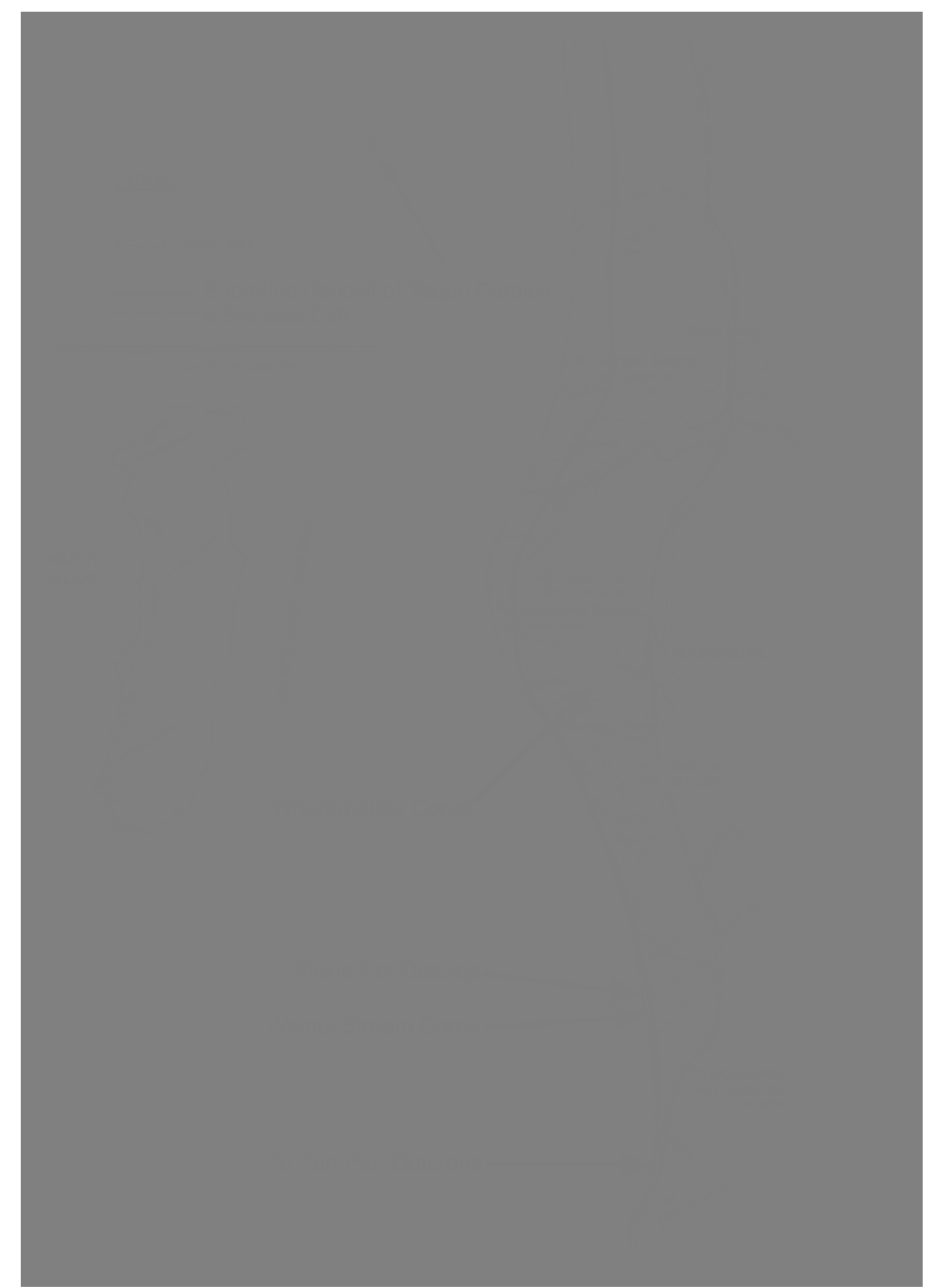

Figure 7.1: The shoreline location of the Kāpiti Coast modified from Gibb (1978a). The modern shoreline is shown as well as its location at the time of sea level stabilisation (6.5ka) and the eruption of Taupo (1764 years BP). 


\subsection{Local Tectonic Setting}

Relative uplift rates for the Kāpiti Coast are not well constrained. Using the interpretations of the Wharemauku Cores, Te Pari Pari Outcrops and previously published material, a synthesis of the present knowledge on the Kāpiti Coast's relative tectonic change is presented, along with possible new constraints of uplift events An uplift event is interpreted using the facies association of units in the Te Pari Pari outcrops and their vertical offset from the modern environment. The basal units of the SFT and NFT are recognised as wave washed foreshore sands (figures $5.13 \& 5.14$ ). The upper contact of these sand units displays a vertical uplift of more than a metre from the modern beach (figure 6.1). The overlying conglomerate units, recognised in this study as foreshore stream deposits that have undergone wave sorting, were also recognised by Adkin (1951) as being indicative of local uplift.

The penultimate movement of the Ohariu fault (figure 2.1), east of the Te Pari Pari outcrops, and is suggested as the cause of this uplift. This correlation is based upon the age control of the SFT (figure 6.1). Pumice from the 3550 years BP Waimihia eruption (Wilson, 1993) occurs within a sand unit, interpreted to have been deposited on a foredune by wave activity. This pumice is $2.6 \mathrm{~m}$ above the present day high tide. The lack of wave sorted, parallel bedding in the overlying CG3 facies conglomerate, indicates that following the deposition of the pumice 3550 years BP, a local uplift event occurred, raising the conglomerate above the foreshore. The Ohariu fault movement that is suggested as the cause of this local uplift is constrained by Litchfield et al. (2006) as occurring between 4810-3260 years calBP. Using the uplifted pumice deposit in the SFT, a new timing of 3550-3260 years calBP is proposed for the Ohariu Fault's penultimate rupture (figure 7.2). The Ohariu Fault trace crosses the nearby Porirua Harbour, where numerous uplift records are evident on the western side of the fault (Gibb and Cox, 2009). 


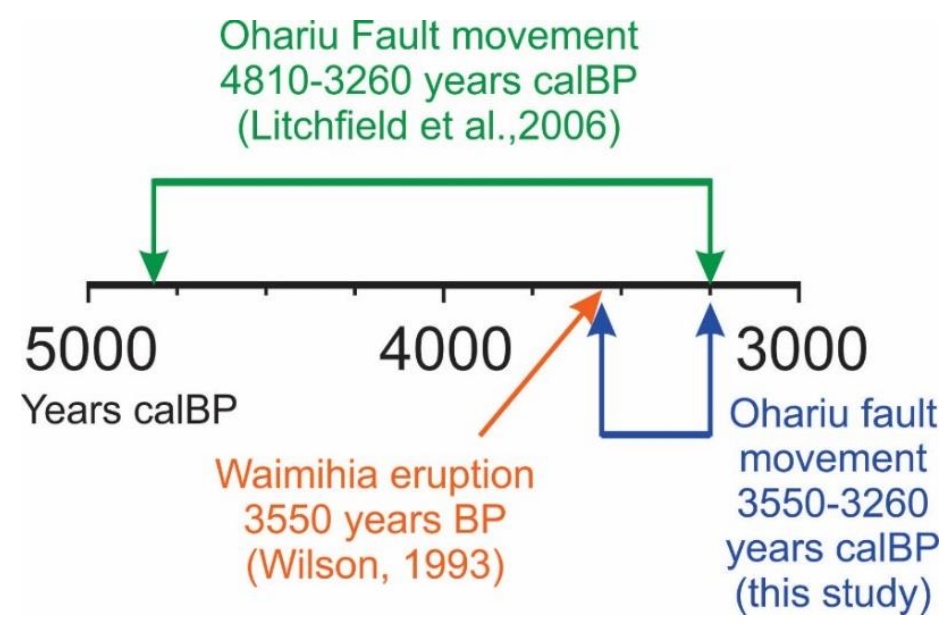

Figure 7.2: The penultimate movement of the Ohariu fault is constrained using the occurrence of an uplifted foredune pumice deposit in the SFT, combined with radiocarbon results from a trenching study north of Paekakariki.

The Wharemauku cores were collected from an elevation of $6 \mathrm{~m}$ at the Kāpiti Airport. The units recognised as foreshore deposits in all four cores have upper contacts positioned between 5-6m deep (figure 6.5), indicating that there has been no uplift or subsidence at this location since the cores were deposited prior to the 1764 Taupo eruption (Wilson, 1993). The most recent movement of the Ohariu Fault occurred 1050-1000 years calBP (Litchfield et al., 2006), suggesting that this movement had no influence upon the Wharemauku cores. This apparent tectonic stability at the Wharemauku core sites, is contrasted with Mcfadgen's (2010) suggestion of around $1 \mathrm{~m}$ of subsidence at Peka Peka to the north. Ewig (2009) attributes subsidence in the vicinity of Peka Peka to a pull apart basin beneath the Kāpiti Coastal Plain, due to a stepped strike slip fault system.

The observed changes in relative base level for the Kāpiti Coast is separated into three settings, as described in this study and others. The observations at the Te Pari Pari Outcrops, indicate that this southern end of the coastal plain has experienced uplift, while the Wharemauku cores have experienced no uplift or subsidence since at least 1764 years BP. Subsidence is recognised at Peka Peka within the northern limb of the Kāpiti Coast in two separate studies (Ewig, 2009, McFadgen, 2010).

The variable vertical displacement recorded along the Kāpiti Coast is likely caused by the local influence of the numerous faults that dissect the area. The attribution of the subsidence at Peka Peka to a stepped strike slip fault, occurring within the North Island 
dextral fault belt (Ewig, 2009), demonstrates the effect that some of the faults that dissect the Kāpiti Coast have on the low lying coastal plain. This may be manifested in the movement of a fault block beneath the coastal plain, similar to those identified further southwest of the coast (Suneson, 1993) or solely isolated movements of local faults. These faults are produced due to the Kāpiti Coast's position between the uplifting Tararua Range to the east and south of the Kāpiti Coast, and the subsidence of the South Wanganui Basin to the northwest (Ewig, 2009) (figure 7.3).

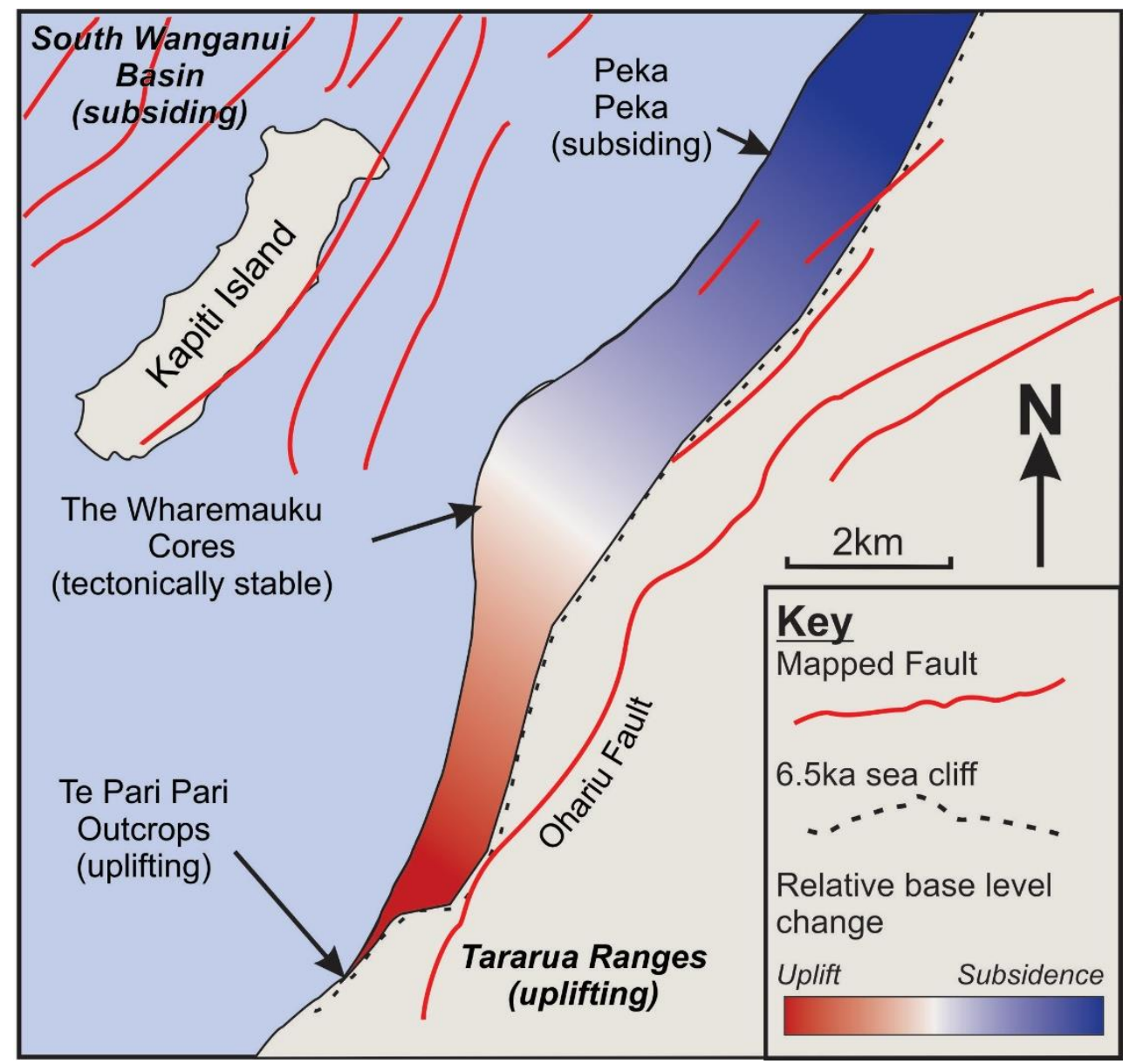

Figure 7.3: A suggestion of the generalised relative changes in base level experienced throughout the Kāpiti Coast. This figure combines the uplift recognised at the Te Pari Pari outcrops of $+1 \mathrm{~m}$ and the tectonic stability at the Wharemauku Cores in this study, with the subsidence of the northern Kāpiti Coast, recognised at Peka Peka of -1m (McFadgen, 2010), attributed to a pull apart basin (Ewig, 2009). Fault positions are reproduced from Ewig (2009) and Litchfield et al. (2006) 


\section{Conclusion}

This study has examined the sedimentary record for the southern limb of the Kāpiti Coastal plain through the description of coastal outcrops and cores collected at the Te Pari Pari cliffs, Wainui Stream and Kāpiti Airport. Using detailed description of the lithostratigraphic units recognised in these records, combined with OSL and radiocarbon dates, new insight on the late Holocene evolution of the Kāpiti Coast has been produced.

The sedimentary characteristics, sample analysis and fossil content combined with a surveyed transect of the modern beach/dune environment has been used to produce a detailed facies scheme. Using vertical facies associations combined with the horizontal correlation between records, a bespoke depositional facies model has been produced for the southern Kāpiti Coast.

This study has constrained the late Holocene sedimentation and progradation of the southern Kāpiti Coast, confirming the dominant southerly sediment supply to the coast. This includes the development of a sandy foreshore at the Te Pari Pari cliffs prior to 5830 years calBP, and the rapid shallowing of sediment at the Wainui Stream as the coast prograded. Within the last 400 years, the Kāpiti Coast's progradation slowed, entering the present erosional cycle, attributed to the growth of the cuspate foreland at Paraparaumu.

This study has demonstrated that the identification of the beach/dune boundary, combined with age control, provides a reliable paleoseismic marker for sea level on the Kāpiti Coast. This has been used to identify an uplift of $1 \mathrm{~m}$ at the Te Pari Pari outcrops, further constraining the penultimate movement of the Ohariu Fault from 4810-3260 to 3550-3260 years calBP. This provides potentially important information to the future planning of coastal hazard mitigation for the Kāpiti Coast.

\subsection{Future Work}

This study has identified several aspects that could be included in future studies of the area:

- A shallow seismic survey of the Kāpiti Coast's subsurface to identify the morphology of the basement rock and its transgressive erosional surface. 
- A shorenormal transect of cores from the base of the $6.5 \mathrm{ka}$ cliff through the Wainui stream. This would provide a systematic multi core record of the shoreface-foreshore sedimentation and progradation of the coastline as well as dune development within this part of the coastal plain.

- Age control through OSL dating is preferred over radiocarbon on wood, due to the potential for reworking of the latter in this dynamic coastal environment.

- The collection of a long core in the northern limb of the Kāpiti Coast near to Peka Peka to compare the sedimentation rates for the northern and southern Kāpiti Coast through the late Holocene, and attempt to further document the subsidence recognised in previous studies.

- The collection of a shorenormal transect of cores across the cuspate foreland at Parapraumu, targeting the beach/dune boundary. Using OSL dating of this boundary, an accurate reconstruction of the cuspate foreland's progradation can be reconstructed.

- Further work on understanding the evolution of the Kāpiti Coast's sediment supply through further detailed analysis of grainsize, composition and roundness. 


\section{References}

ADAMS, C. \& GRAHAM, I. 1996. Metamorphic and tectonic geochronology of the Torlesse terrane, Wellington, New Zealand. New Zealand Journal of Geology and Geophysics, $39,157-180$.

ADKIN, G. Geology of the Paekakariki area of the coastal lowland of Western Wellington. Transactions of the Royal Society of New Zealand, 1951. 157-176.

ANDERTON, P. W. 1981. Structure and evolution of the south Wanganui Basin, New Zealand. New Zealand journal of geology and geophysics, 24, 39-63.

ARE, F. A., GRIGORIEV, M. N., GRUZDEVA, O. A., HUBBERTEN, H.-W., RACHOLD, V., RAZUMOV, S. O., SCHNEIDER, W., PFEIFFER, E.-M., SCHIRRMEISTER, L. \& WAGNER, D. 2003. Offshore coastal studies-shoreface profiles measurements. AWI.

AUBREY, D. G. 1979. Seasonal patterns of onshore/offshore sediment movement. Journal of Geophysical Research: Oceans, 84, 6347-6354.

BALDI, M., BURGESS, S., MULLAN, B., SALINGER, J., RAMSEY, D. \& BELL, R. 2007. Updated climate change scenarios for the Kapiti Coast. NIWA Client Report.

BEAL, M. A. \& SHEPARD, F. P. 1956. A use of roundness to determine depositional environments. Journal of Sedimentary Research, 26.

BEGG, J., JOHNSTON, M. \& MCSAVENEY, E. 2000. Geology of the Wellington area.

BEU, A. G. \& RAINE, J. 2009. Revised descriptions of New Zealand Cenozoic Mollusca from Beu and Maxwell (1990). GNS Science miscellaneous series, 27.

BLAKE, S., WILSON, C., SMITH, I. \& WALKER, G. 1992. Petrology and dynamics of the Waimihia mixed magma eruption, Taupo Volcano, New Zealand. Journal of the Geological Society, 149, 193-207.

BLOTT, S. J. \& PYE, K. 2001. GRADISTAT: a grain size distribution and statistics package for the analysis of unconsolidated sediments. Earth surface processes and Landforms, 26, $1237-1248$

BOGGS, S. 2011. Principles of sedimentology and stratigraphy, Pearson Prentice Hall.

BRANDER, R. W. 1999. Field observations on the morphodynamic evolution of a low-energy rip current system. Marine geology, 157, 199-217.

BRISTOW, C. S., CHROSTON, P. N. \& BAILEY, S. D. 2000. The structure and development of foredunes on a locally prograding coast: insights from ground-penetrating radar surveys, Norfolk, UK. Sedimentology, 47, 923-944.

BRODIE, J. W. 1960. Coastal surface currents around New Zealand. New Zealand journal of geology and geophysics, 3, 235-252. 
BYRNE, M.-L. \& MCCANN, S. 1990. Stratification and sedimentation in complex vegetated coastal dunes, Sable Island, Nova Scotia. Sedimentary Geology, 66, 165-179.

CHAKRABARTI, P. 1995. Evolutionary history of the coastal quaternaries of the Bengal Plain, India. PROCEEDINGS-INDIAN NATIONAL SCIENCE ACADEMY PART A, 61, 343-354.

CHEEL, R. J. \& LECKIE, D. A. 1992. Coarse-grained storm beds of the Upper Cretaceous Chungo Member (Wapiabi Formation), southern Alberta, Canada. Journal of Sedimentary Research, 62.

CHISWELL, S. M. \& STEVENS, C. L. 2010. Lagrangian and Eulerian estimates of circulation in the lee of Kapiti Island, New Zealand. Continental Shelf Research, 30, 515-532.

CLEMENT, A. J., SLOSS, C. R. \& FULLER, I. C. 2010. Late quaternary geomorphology of the Manawatu coastal plain, North Island, New Zealand. Quaternary International, 221, $36-45$

CLIFTON, H. E. 1969. Beach lamination: nature and origin. Marine Geology, 7, 553-559.

COCHRAN, U., HANNAH, M., HARPER, M., VAN DISSEN, R., BERRYMAN, K. \& BEGG, J. 2007. Detection of large, Holocene earthquakes using diatom analysis of coastal sedimentary sequences, Wellington, New Zealand. Quaternary Science Reviews, 26, 1129-1147.

COCHRAN, U. A. 2002. Detection of large Holocene earthquakes in the sedimentary record of Wellington, New Zealand, using diatom analysis. PhD, Victoria University of Wellington.

COWIE, J. 1963. Dune-building phases in the Manawatu district, New Zealand. New Zealand journal of geology and geophysics, 6, 268-280.

COWIE, N., HEALY, T. \& MCCOMB, P. 2009. Sediment flux on the high energy Taranaki Coast, New Zealand. Journal of Coastal Research, 703.

DAVIS, R. J. 2012. Coastal sedimentary environments, Springer Science \& Business Media.

DIX, T. G. 1970. Biology of Evechinus chloroticus (Echinoidea: Echinometridae) from different localities: 1. General. New Zealand journal of marine and freshwater research, 4, 91116.

DUNBAR, G. \& BARRETT, P. 2005. Estimating palaeobathymetry of wave-graded continental shelves from sediment texture. Sedimentology, 52, 253-269.

EVANS, G. 1979. Quaternary transgressions and regressions. Journal of the Geological Society, $136,125-132$.

EWIG, E. 2009. Lithospheric shortening and ductile deformation in a back-arc setting: South Wanganui Basin, New Zealand.

EWING, M., WORZEL, J., STEENLAND, N. \& PRESS, F. 1950. GEOPHYSICAL INVESTIGATIONS IN THE EMERGED AND SUBMERGED ATLANTIC COASTAL PLAIN PART V: WOODS HOLE, 
NEW YORK, AND CAPE MAY SECTIONS. Geological Society of America Bulletin, 61, 877892.

EWING, R. \& MACPHERSON, R. F. 1986. The history of New Zealand aviation, Heinemann. FINKL, C. W. 2004. Coastal classification: systematic approaches to consider in the development of a comprehensive scheme. Journal of Coastal Research, 166-213.

FLEMING, C. 1972. The contribution of C14 dates to the Quaternary geology of the 'golden coast', Western Wellington. Tuatara 19 (2): 61, 9.

FLEMING, C. A. 1965. Radiocarbon dating from a post-glacial beach in Western Wellington. New Zealand Journal of Geology and Geophysics, 8, 1222-1223.

FOLK, R. L. \& WARD, W. C. 1957. Brazos River bar: a study in the significance of grain size parameters. Journal of Sedimentary Research, 27.

FORD, J., KESSLER, H., COOPER, A., PRICE, S. \& HUMPAGE, A. 2010. An enhanced classification of artificial ground.

FORD, J., PRICE, S., COOPER, A. \& WATERS, C. 2014. An assessment of lithostratigraphy for anthropogenic deposits. Geological Society, London, Special Publications, 395, 55-89.

FRYBERGER, S. G., AHLBRANDT, T. S. \& ANDREWS, S. 1979. Origin, sedimentary features, and significance of Low-Angle Eolian. Journal of Sedimentary Research, 49.

GIBB, J. 1986. A New Zealand regional Holocene eustatic sea-level curve and its application to determination of vertical tectonic movements. Royal Society of New Zealand Bulletin, 24, 377-395.

GIBB, J. G. 1978a. The Problem of Coastal Erosion Along the Golden Coast, Western Wellington, New Zealand, Water \& Soil Division, Ministry of Works and Development.

GIBB, J. G. 1978b. Rates of coastal erosion and accretion in New Zealand. New Zealand journal of marine and freshwater research, 12, 429-456.

GIBB, J. G. \& COX, G. J. 2009. Patterns and rates of sedimentation within Porirua Harbour, Porirua City Council.

GIBB, J. G. \& DEPLEDGE, D. R. 1980. Coastal Erosion at Paekakariki, Wellington's West Coast. Ministry of Works and Development.

GOFF, J., ROUSE, H., JONES, S., HAYWARD, B., COCHRAN, U., MCLEA, W., DICKINSON, W. \& MORLEY, M. 2000. Evidence for an earthquake and tsunami about 3100-3400yr ago, and other catastrophic saltwater inundations recorded in a coastal lagoon, New Zealand. Marine Geology, 170, 231-249.

GOFF, J. R., HICKS, D. M. \& HURREN, H. 2007. Tsunami geomorphology in New Zealand.

GRANT, P. J. 1985. Major periods of erosion and alluvial sedimentation in New Zealand during the Late Holocene. Journal of the Royal Society of New Zealand, 15, 67-121. 
GRIFFITHS, G. \& GLASBY, G. 1985. Input of river-derived sediment to the New Zealand continental shelf: I. Mass. Estuarine, coastal and shelf science, 21, 773-787.

HANCOX, G. 2003. Preliminary report on landslides, gully erosion, and debris flood effects in the Paekakariki area as a result of the 3 October 2003 flood. Institute of Geological \& Nuclear Sciences client report 2003/120, 19 p.

HART, B. \& PLINT, A. 1989. Gravelly shoreface deposits: a comparison of modern and ancient facies sequences. Sedimentology, 36, 551-557.

HART, B. S. \& PLINT, A. G. 2003. Stratigraphy and sedimentology of shoreface and fluvial conglomerates: insights from the Cardium Formation in NW Alberta and adjacent British Columbia. Bulletin of Canadian Petroleum Geology, 51, 437-464.

HAWKE, R. \& MCCONCHIE, J. 2006. Dune phases in the Otaki-Te Horo area (New Zealand): a geomorphic history. Earth Surface Processes and Landforms, 31, 633-645.

HAWKE, R. M. \& MCCONCHIE, J. A. 2005. The source, age, and stabilisation of the Koputaroa dunes, Otaki-Te Horo, New Zealand.

HERNÁNDEZ-MOLINA, F., FERNÁNDEZ-SALAS, L., LOBO, F., SOMOZA, L., DÍAZ-DEL-RÍO, V. \& DIAS, J. A. 2000. The infralittoral prograding wedge: a new large-scale progradational sedimentary body in shallow marine environments. Geo-Marine Letters, 20, 109-117.

HERON, D., VAN DISSEN, R. \& SAWA, M. 1998. Late Quaternary movement on the Ohariu Fault, Tongue Point to MacKays Crossing, North Island, New Zealand. New Zealand Journal of Geology and Geophysics, 41, 419-439.

HESP, P. 1988. Morphology, dynamics and internal stratification of some established foredunes in southeast Australia. Sedimentary Geology, 55, 17-41.

HOGG, A. G., HUA, Q., BLACKWELL, P. G., NIU, M., BUCK, C. E., GUILDERSON, T. P., HEATON, T. J., PALMER, J. G., REIMER, P. J. \& REIMER, R. W. 2013. SHCal13 Southern Hemisphere calibration, 0-50,000 years cal BP. Radiocarbon, 55, 1-15.

HUMMEL, G. \& KOCUREK, G. 1984. Interdune areas of the back-island dune field, North Padre Island, Texas. Sedimentary Geology, 39, 1-26.

JAFFE, B. E., STERNBERG, R. W. \& SALLENGER, A. H. 1985. The role of suspended sediment in shore-normal beach profile changes. Coastal Engineering 1984.

KASPER-ZUBILLAGA, J. \& DICKINSON, W. 2001. Discriminating depositional environments of sands from modern source terranes using modal analysis. Sedimentary Geology, 143, 149-167.

KASPER-ZUBILLAGA, J., ORTIZ-ZAMORA, G., DICKINSON, W., URRUTIA-FUCUGAUCHI, J. \& SOLER-ARECHALDE, A. 2007. Textural and compositional controls on modern beach and dune sands, New Zealand. Earth Surface Processes and Landforms, 32, 366-389. 
KENNEDY, D. M. 2008. Recent and future higher sea levels in New Zealand: A review. New Zealand Geographer, 64, 105-116.

KIRBY, R. 2002. Chapter Four Distinguishing accretion from erosion-dominated muddy coasts. Proceedings in Marine Science, 4, 61-81.

KIRK, R. 1980. Mixed sand and gravel beaches: morphology, processes and sediments. Progress in physical geography, 4, 189-210.

KOLMER, J. 1973. A wave tank analysis of the beach foreshore grain size distribution. Journal of Sedimentary Research, 43.

KRAFT, J. C. 1971. Sedimentary facies patterns and geologic history of a Holocene marine transgression. Geological Society of America Bulletin, 82, 2131-2158.

KRAMER, N. \& WOHL, E. 2015. Driftcretions: The legacy impacts of driftwood on shoreline morphology. Geophysical Research Letters, 42, 5855-5864.

KUMAR, N. \& SANDERS, J. E. 1976. Characteristics of shoreface storm deposits: modern and ancient examples. Journal of Sedimentary Research, 46.

LAMB, S. \& VELLA, P. 1987. The last million years of deformation in part of the New Zealand plate-boundary zone. Journal of structural geology, 9, 877-891.

LEWIS, K. 1979. A storm-dominated inner shelf, western Cook Strait, New Zealand. Marine geology, 31, 31-43.

LI, X., KONG, D., TAN, H. \& WANG, X. 2007. Changes in soil and vegetation following stabilisation of dunes in the southeastern fringe of the Tengger Desert, China. Plant and Soil, 300, 221-231.

LINZ 2017a. Secondary Ports Table. New Zealand Tidal Predictions. Land Information New Zealand.

LINZ. 2017b. Tide Predictions [Online]. New Zealand Government. Available: http://www.linz.govt.nz/sea/tides/tide-predictions [Accessed].

LITCHFIELD, N. \& BERRYMAN, K. 2006. Relations between postglacial fluvial incision rates and uplift rates in the North Island, New Zealand. Journal of Geophysical Research: Earth Surface, 111.

LITCHFIELD, N., VAN DISSEN, R., HERON, D. \& RHOADES, D. 2006. Constraints on the timing of the three most recent surface rupture events and recurrence interval for the Ohariu Fault: trenching results from MacKays Crossing, Wellington, New Zealand.

LITCHFIELD, N., VAN DISSEN, R., LANGRIDGE, R., HERON, D. \& PRENTICE, C. 2004. Timing of the most recent surface rupture event on the Ohariu Fault near Paraparaumu, New Zealand. New Zealand Journal of Geology and Geophysics, 47, 123-127. 
LULY, J., GRINDROD, J. \& PENNY, D. 2006. Holocene palaeoenvironments and change at ThreeQuarter Mile Lake, Silver Plains Station, Cape York Peninsula, Australia. The Holocene, $16,1085-1094$.

MACCARTHY, G. R. 1935. Eolian sands, a comparison. American Journal of Science, 81-95.

MCCUBBIN, D. G. 1982. Barrier-island and strand-plain facies. Sandstone Depositional Environments: Memoir no. 31, American Association of Petroleum Geologists, .

MCFADGEN, B. 1980. Age relationship between a Maori plaggen soil and Moa-hunter sites on the west Wellington coast. New Zealand Journal of Geology and Geophysics, 23, 249256.

MCFADGEN, B. 1985. Late Holocene stratigraphy of coastal deposits between Auckland and Dunedin, New Zealand. Journal of the Royal Society of New Zealand, 15, 27-65.

MCFADGEN, B. 1997. Archaeology of the Wellington Conservancy: Kapiti-Horowhenua. $A$ prehistoric and palaeoenvironmental study. Department of Conservation, Wellington.

MCFADGEN, B. 2010. Archaeoseismology - A New Zealand Perspective. A salute to the Captain - Celebrating the 100th birthday of Emeritus Professor J B Mackie, 85-100.

MCLEAN, R. \& KIRK, R. M. 1969. Relationships between grain size, size-sorting, and foreshore slope on mixed sand-shingle beaches. New Zealand Journal of Geology and Geophysics, $12,138-155$.

MIDDLETON, G. V. 1973. Johannes Walther's law of the correlation of facies. Geological Society of America Bulletin, 84, 979-988.

MORTON, R. A., GELFENBAUM, G. \& JAFFE, B. E. 2007. Physical criteria for distinguishing sandy tsunami and storm deposits using modern examples. Sedimentary Geology, 200, 184207.

MUCKERSIE, C. \& SHEPHERD, M. 1995. Dune phases as time-transgressive phenomena, Manawatu, New Zealand. Quaternary International, 26, 61-67.

NAISH, T. \& KAMP, P. J. 1997. Sequence stratigraphy of sixth-order (41 ky) PliocenePleistocene cyclothems, Wanganui basin, New Zealand: a case for the regressive systems tract. Geological Society of America Bulletin, 109, 978-999.

NIELSEN, N. \& NIELSEN, J. 2006. Development of a washover fan on a transgressive barrier, Skallingen, Denmark. Journal of Coastal Research, Special, 107-111.

OLIVER, R. L. 1948. The Otaki Sandstone and its geological history, Department of Scientific and Industrial Research.

PACKARD, R. 1957. Some physical properties of Taupo pumice soils of New Zealand. Soil science, 83, 273-290.

PERRETT, T. L. 1990. Variations in Sediment Texture and Biota Off a Wave Dominated Coast, Peka Peka Beach, New Zealand. 
POWERS, M. C. 1953. A new roundness scale for sedimentary particles. Journal of Sedimentary Research, 23.

RACHOLD, V., GRIGORIEV, M. N., ARE, F. E., SOLOMON, S., REIMNITZ, E., KASSENS, H. \& ANTONOW, M. 2000. Coastal erosion vs riverine sediment discharge in the Arctic Shelf seas. International Journal of Earth Sciences, 89, 450-460.

RAMSEY, C. B. 2009a. Bayesian analysis of radiocarbon dates. Radiocarbon, 51, 337-360.

RAMSEY, C. B. 2009b. Dealing with outliers and offsets in radiocarbon dating. Radiocarbon, 51, 1023-1045.

REINSON, G. E. 1979. Facies models 14. Barrier island systems. Geoscience Canada, 6.

RUSSELL, R. D. 1939. Effects of transportation on sedimentary particles: Part 1. Transportation.

SEDDON, G. 1972. Sense of Place a Response to an Environment, the Swan Coastal Plain, Western Australia.

SHAND, R. D. 2012. Kapiti Coast Erosion.

SHEPARD, F. P. \& YOUNG, R. 1961. Distinguishing between beach and dune sands. Journal of Sedimentary Research, 31.

SNEED, E. D. \& FOLK, R. L. 1958. Pebbles in the lower Colorado River, Texas a study in particle morphogenesis. The Journal of Geology, 66, 114-150.

STANLEY, D. J., HAIT, A. K. \& JORSTAD, T. F. 2000. Iron-stained quartz to distinguish Holocene deltaic from Pleistocene alluvial deposits in small core samples. Journal of Coastal Research, 357-367.

SUNESON, N. H. 1993. The geology of the Torlesse complex along the Wellington area coast, North Island, New Zealand. New Zealand journal of geology and geophysics, 36, 369384.

TE PUNGA, M. 1962. Some geological features of the Otaki-Waikanae district. New Zealand Journal of Geology and Geophysics, 5, 517-530.

VAN DISSEN, R. \& HERON, D. 2003. Earthquake fault trace survey, Kapiti Coast District. Institute of Geological \& Nuclear Sciences Client Report, 77.

VANDERGOES, M. J., FITZSIMONS, S. J. \& NEWNHAM, R. M. 1997. Late glacial to Holocene vegetation and climate change in the eastern Takitimu Mountains, western Southland, New Zealand. Journal of the Royal Society of New Zealand, 27, 53-66.

WALKER, R. G. \& JAMES, N. P. 1992. Facies models: response to sea level change, St. John's, Nfld.: Geological Association of Canada= Association géologique du Canada.

WALLACE, L. M., BEAVAN, J., MCCAFFREY, R. \& DARBY, D. 2004. Subduction zone coupling and tectonic block rotations in the North Island, New Zealand. Journal of Geophysical Research: Solid Earth, 109. 
WELLMAN, H. 1962. Holocene of the North Island of New Zealand: a coastal reconnaissance, The Society.

WELLMAN, H. Tilted marine beach ridges at Cape Turakirae, NZ. Sea level changes and crustal movements of the Pacific during the Pliocene and Post-Pliocene time. Symposium, 1967.

WILSON, C. 1993. Stratigraphy, chronology, styles and dynamics of late Quaternary eruptions from Taupo volcano, New Zealand. Philosophical Transactions of the Royal Society of London A: Mathematical, Physical and Engineering Sciences, 343, 205-306.

WRIGHT, L. W. 1988. The Sand Country of the 'Golden Coast', Wellington, New Zealand. New Zealand Geographer, 44, 28-31.

YING, W. \& XIANKUN, K. 1989. Cheniers on the east coastal plain of China. Marine Geology, 90, 321-335.

ZUSCHIN, M., STACHOWITSCH, M. \& STANTON, R. J. 2003. Patterns and processes of shell fragmentation in modern and ancient marine environments. Earth-Science Reviews, $63,33-82$. 


\section{Appendix 1: Grainsize}

The grainsize data is tabulated in the following section with sample details in columns. The grainsize data is presented as table with statistical parameters. The arrangement of the data is as follows:

- WS3 core on page 138

- $\mathrm{AB} 1$ core on page 144

- $\mathrm{AB} 2$ core on page 146

- $\mathrm{AB} 3$ core on page 148

- $\mathrm{AB} 4$ core on page 151

- Waikanae Beach Transect on page 153 


\begin{tabular}{|c|c|c|c|c|c|c|}
\hline & WS3-1.6 & WS3-1.8 & WS3-2.05 & WS3-2.4A & WS3-2.9 & WS3-3.4 \\
\hline TEXTURAL GROUP: & Sand & Sand & Sand & Sand & Sand & Sand \\
\hline SEDIMENT NAME: & $\begin{array}{l}\text { Moderately Well- } \\
\text { sorted Fine-sand }\end{array}$ & $\begin{array}{l}\text { Well-sorted } \\
\text { Fine-sand }\end{array}$ & $\begin{array}{l}\text { Moderately Well- } \\
\text { sorted Fine-sand }\end{array}$ & $\begin{array}{l}\text { Moderately-sorted } \\
\text { Medium Sand }\end{array}$ & $\begin{array}{l}\text { Moderately-sorted } \\
\text { Medium Sand }\end{array}$ & $\begin{array}{l}\text { Moderately Well- } \\
\text { sorted Fine-sand }\end{array}$ \\
\hline MEAN & 244.6 & 220.4 & 252.6 & 309.3 & 352.8 & 199.1 \\
\hline SORTING (std. dev.) & 130.8 & 93.17 & 166.2 & 177.4 & 167.3 & 90.01 \\
\hline SKEWNESS: & Coarse Skewed & $\begin{array}{l}\text { Coarse } \\
\text { Skewed }\end{array}$ & Coarse Skewed & Symmetrical & Fine Skewed & Fine Skewed \\
\hline MODE $1(\mu \mathrm{m}):$ & 203.7 & 203.7 & 203.7 & 245.5 & 356.5 & 185.5 \\
\hline MODE $2(\mu \mathrm{m})$ : & 517.8 & & 517.8 & & & \\
\hline D10 ( $\mu \mathrm{m}):$ & 137.8 & 139.3 & 144.1 & 146.8 & 167.1 & 119.0 \\
\hline $\mathrm{D} 50(\mu \mathrm{m}):$ & 213.1 & 202.6 & 204.7 & 271.7 & 329.5 & 187.6 \\
\hline $\mathrm{D} 90(\mu \mathrm{m}):$ & 417.8 & 312.9 & 437.7 & 522.2 & 580.6 & 281.1 \\
\hline (D90 / D10) $(\mu \mathrm{m}):$ & 3.031 & 2.246 & 3.036 & 3.558 & 3.475 & 2.363 \\
\hline (D90 - D10) $(\mu \mathrm{m}):$ & 279.9 & 173.6 & 293.6 & 375.5 & 413.5 & 162.1 \\
\hline (D75 / D25) ( $\mu \mathrm{m}):$ & 1.588 & 1.492 & 1.519 & 1.897 & 1.918 & 1.527 \\
\hline (D75 - D25) $(\mu \mathrm{m}):$ & 100.6 & 81.99 & 87.40 & 179.8 & 215.6 & 79.69 \\
\hline \% GRAVEL: & $0.0 \%$ & $0.0 \%$ & $0.0 \%$ & $0.0 \%$ & $0.0 \%$ & $0.0 \%$ \\
\hline \% SAND: & $97.5 \%$ & $98.2 \%$ & $100.0 \%$ & $96.1 \%$ & $97.0 \%$ & $95.9 \%$ \\
\hline$\%$ MUD & $2.5 \%$ & $1.8 \%$ & $0.0 \%$ & $3.9 \%$ & $3.0 \%$ & $4.1 \%$ \\
\hline
\end{tabular}




\begin{tabular}{|c|c|c|c|c|c|c|}
\hline & WS3-3.9 & WS3-5.8 & WS3-6.2 & WS3-7.3A & WS3-8.7 & WS3-9.3 \\
\hline TEXTURAL GROUP: & Sand & Muddy-sand & Sand & Sand & Sand & Muddy-sand \\
\hline SEDIMENT NAME: & $\begin{array}{l}\text { Well-sorted } \\
\text { Fine-sand }\end{array}$ & $\begin{array}{l}\text { Very Coarse Silty } \\
\text { Fine-sand }\end{array}$ & $\begin{array}{l}\text { Moderately Well- } \\
\text { sorted Fine-sand }\end{array}$ & $\begin{array}{l}\text { Moderately-sorted } \\
\text { Fine-sand }\end{array}$ & $\begin{array}{l}\text { Well-sorted } \\
\text { Fine-sand }\end{array}$ & $\begin{array}{l}\text { Very Coarse Silty } \\
\text { Fine-sand }\end{array}$ \\
\hline MEAN & 169.5 & 130.1 & 154.3 & 168.4 & 161.9 & 91.63 \\
\hline SORTING (std. dev.) & 52.19 & 63.88 & 58.61 & 89.62 & 39.66 & 65.67 \\
\hline SKEWNESS: & Fine Skewed & Very Fine Skewed & Very Fine Skewed & Very Fine Skewed & Symmetrical & Very Fine Skewed \\
\hline MODE $1(\mu \mathrm{m}):$ & 169.0 & 154.0 & 169.0 & 169.0 & 169.0 & 140.3 \\
\hline MODE $2(\mu \mathrm{m}):$ & & & & & & 41.72 \\
\hline D10 $(\mu \mathrm{m}):$ & 112.6 & 27.44 & 69.90 & 67.85 & 111.8 & 3.855 \\
\hline D50 $(\mu \mathrm{m}):$ & 169.3 & 138.9 & 158.0 & 162.6 & 158.9 & 101.7 \\
\hline $\mathrm{D} 90(\mu \mathrm{m}):$ & 234.3 & 207.8 & 225.5 & 244.4 & 216.2 & 175.1 \\
\hline (D90 / D10) $(\mu \mathrm{m}):$ & 2.081 & 7.575 & 3.226 & 3.602 & 1.934 & 45.42 \\
\hline (D90 - D10) $(\mu \mathrm{m}):$ & 121.7 & 180.4 & 155.6 & 176.6 & 104.4 & 171.2 \\
\hline (D75 / D25) ( $\mu \mathrm{m}):$ & 1.456 & 1.991 & 1.541 & 1.598 & 1.420 & 7.147 \\
\hline (D75 - D25) ( $\mu \mathrm{m}):$ & 63.60 & 87.03 & 67.57 & 75.48 & 55.77 & 124.0 \\
\hline \% GRAVEL: & $0.0 \%$ & $0.0 \%$ & $0.0 \%$ & $0.0 \%$ & $0.0 \%$ & $0.0 \%$ \\
\hline \% SAND: & $96.4 \%$ & $81.8 \%$ & $91.1 \%$ & $90.8 \%$ & $100.0 \%$ & $62.3 \%$ \\
\hline \% MUD: & $3.6 \%$ & $18.2 \%$ & $8.9 \%$ & $9.2 \%$ & $0.0 \%$ & $37.7 \%$ \\
\hline
\end{tabular}




\begin{tabular}{|c|c|c|c|c|c|c|}
\hline & WS3-9.9 & WS3-10.5 & WS3-11.1 & WS3-12.6 & WS3-13.6 & WS3-14.6 \\
\hline TEXTURAL GROUP: & Sand & Sand & Sand & Muddy-sand & Muddy-sand & Muddy-sand \\
\hline SEDIMENT NAME: & $\begin{array}{l}\text { Moderately Well- } \\
\text { sorted Fine-sand }\end{array}$ & $\begin{array}{c}\text { Moderately- } \\
\text { sorted Fine-sand }\end{array}$ & $\begin{array}{c}\text { Moderately } \\
\text { Well-sorted } \\
\text { Fine-sand }\end{array}$ & $\begin{array}{l}\text { Very Coarse Silty } \\
\text { Fine-sand }\end{array}$ & $\begin{array}{l}\text { Very Coarse Silty } \\
\text { Fine-sand }\end{array}$ & $\begin{array}{l}\text { Very Coarse } \\
\text { Silty Fine-sand }\end{array}$ \\
\hline MEAN & 145.6 & 141.7 & 139.6 & 99.26 & 189.8 & 97.34 \\
\hline SORTING (std. dev.) & 47.88 & 51.34 & 48.91 & 61.07 & 173.5 & 61.09 \\
\hline SKEWNESS: & Fine Skewed & Very Fine Skewed & $\begin{array}{l}\text { Very Fine } \\
\text { Skewed }\end{array}$ & Very Fine Skewed & Fine Skewed & $\begin{array}{l}\text { Very Fine } \\
\text { Skewed }\end{array}$ \\
\hline MODE $1(\mu \mathrm{m}):$ & 154.0 & 154.0 & 154.0 & 140.3 & 169.0 & 140.3 \\
\hline MODE $2(\mu \mathrm{m}):$ & & & & 45.80 & 471.7 & \\
\hline D10 $(\mu \mathrm{m}):$ & 88.27 & 81.96 & 76.71 & 7.017 & 45.71 & 5.822 \\
\hline D50 $(\mu \mathrm{m}):$ & 146.7 & 145.8 & 142.8 & 111.2 & 153.4 & 110.0 \\
\hline $\mathrm{D} 90(\mu \mathrm{m}):$ & 205.0 & 203.0 & 198.5 & 173.4 & 343.3 & 171.4 \\
\hline (D90 / D10) $(\mu \mathrm{m}):$ & 2.323 & 2.477 & 2.587 & 24.72 & 7.510 & 29.44 \\
\hline (D90 - D10) $(\mu \mathrm{m}):$ & 116.8 & 121.1 & 121.8 & 166.4 & 297.6 & 165.5 \\
\hline (D75 / D25) ( $\mu \mathrm{m}):$ & 1.477 & 1.503 & 1.498 & 3.665 & 2.168 & 3.913 \\
\hline$(D 75-D 25)(\mu \mathrm{m}):$ & 56.85 & 58.61 & 57.12 & 105.9 & 117.9 & 107.6 \\
\hline \% GRAVEL: & $0.0 \%$ & $0.0 \%$ & $0.0 \%$ & $0.0 \%$ & $0.0 \%$ & $0.0 \%$ \\
\hline \% SAND: & $94.2 \%$ & $91.5 \%$ & $92.4 \%$ & $69.0 \%$ & $86.6 \%$ & $68.4 \%$ \\
\hline \% MUD: & $5.8 \%$ & $8.5 \%$ & $7.6 \%$ & $31.0 \%$ & $13.4 \%$ & $31.6 \%$ \\
\hline
\end{tabular}




\begin{tabular}{|c|c|c|c|c|c|c|}
\hline & WS3-15.6 & WS3-16.6 & WS3-17.5 & WS3-18.5 & WS3-19.5 & WS3-20.4 \\
\hline TEXTURAL GROUP: & Sand & Sand & Sand & Sand & Muddy-sand & Muddy-sand \\
\hline SEDIMENT NAME: & $\begin{array}{c}\text { Moderately- } \\
\text { sorted Fine-sand }\end{array}$ & $\begin{array}{l}\text { Well-sorted Fine- } \\
\text { sand }\end{array}$ & $\begin{array}{l}\text { Well-sorted } \\
\text { Fine-sand }\end{array}$ & $\begin{array}{l}\text { Well-sorted Fine- } \\
\text { sand }\end{array}$ & $\begin{array}{l}\text { Very Coarse Silty } \\
\text { Very Fine-sand }\end{array}$ & $\begin{array}{c}\text { Very Coarse Silty } \\
\text { Very Fine-sand }\end{array}$ \\
\hline MEAN & 133.7 & 140.4 & 133.8 & 134.4 & 93.01 & 94.80 \\
\hline SORTING (std. dev.) & 47.70 & 37.24 & 42.76 & 32.07 & 51.41 & 54.39 \\
\hline SKEWNESS: & Very Fine Skewed & Symmetrical & Symmetrical & Symmetrical & Very Fine Skewed & Very Fine Skewed \\
\hline MODE $1(\mu \mathrm{m})$ : & 154.0 & 140.3 & 140.3 & 127.8 & 116.4 & 127.8 \\
\hline D10 $(\mu \mathrm{m}):$ & 83.34 & 93.77 & 86.98 & 94.04 & 22.35 & 6.743 \\
\hline D50 $(\mu \mathrm{m}):$ & 138.4 & 136.4 & 131.9 & 131.1 & 90.81 & 106.4 \\
\hline $\mathrm{D} 90(\mu \mathrm{m}):$ & 188.4 & 192.4 & 189.5 & 178.9 & 162.1 & 158.4 \\
\hline (D90 / D10) ( $\mu \mathrm{m}):$ & 2.261 & 2.051 & 2.179 & 1.903 & 7.251 & 23.50 \\
\hline (D90 - D10) $(\mu \mathrm{m}):$ & 105.1 & 98.60 & 102.5 & 84.89 & 139.8 & 151.7 \\
\hline (D75 / D25) ( $\mu \mathrm{m}):$ & 1.490 & 1.473 & 1.505 & 1.421 & 2.362 & 2.762 \\
\hline$(\mathrm{D} 75$ - D25) $(\mu \mathrm{m}):$ & 54.40 & 52.93 & 53.85 & 46.24 & 74.06 & 86.08 \\
\hline \% GRAVEL: & $0.0 \%$ & $0.0 \%$ & $0.0 \%$ & $0.0 \%$ & $0.0 \%$ & $0.0 \%$ \\
\hline \% SAND: & $92.7 \%$ & $100.0 \%$ & $96.1 \%$ & $100.0 \%$ & $69.7 \%$ & $71.9 \%$ \\
\hline \% MUD: & $7.3 \%$ & $0.0 \%$ & $3.9 \%$ & $0.0 \%$ & $30.3 \%$ & $28.1 \%$ \\
\hline
\end{tabular}




\begin{tabular}{|c|c|c|c|c|c|c|}
\hline & WS3-21.35 & WS3-22.3 & WS3-23.3 & WS3-24.3A & WS3-24.6 & WS3-25.3 \\
\hline TEXTURAL GROUP: & Muddy-sand & Muddy-sand & Muddy-sand & Muddy-sand & Muddy-sand & Sand \\
\hline SEDIMENT NAME: & $\begin{array}{l}\text { Very Coarse Silty } \\
\text { Fine-sand }\end{array}$ & $\begin{array}{c}\text { Very Coarse } \\
\text { Silty Fine-sand }\end{array}$ & $\begin{array}{l}\text { Coarse Silty } \\
\text { Fine-sand }\end{array}$ & $\begin{array}{l}\text { Very Coarse Silty } \\
\text { Very Fine-sand }\end{array}$ & $\begin{array}{l}\text { Very Coarse Silty } \\
\text { Very Fine-sand }\end{array}$ & $\begin{array}{c}\text { Well-sorted } \\
\text { Very Fine-sand }\end{array}$ \\
\hline MEAN & 114.5 & 116.8 & 118.2 & 108.6 & 95.84 & 121.6 \\
\hline SORTING (std. dev.) & 53.01 & 51.87 & 45.78 & 51.33 & 50.73 & 36.56 \\
\hline SKEWNESS: & $\begin{array}{l}\text { Very Fine } \\
\text { Skewed }\end{array}$ & $\begin{array}{l}\text { Very Fine } \\
\text { Skewed }\end{array}$ & $\begin{array}{l}\text { Very Fine } \\
\text { Skewed }\end{array}$ & Very Fine Skewed & Very Fine Skewed & Symmetrical \\
\hline MODE $1(\mu \mathrm{m})$ : & 127.8 & 127.8 & 127.8 & 127.8 & 116.4 & 116.4 \\
\hline MODE $2(\mu \mathrm{m})$ : & & & & 45.80 & 45.80 & \\
\hline D10 $(\mu \mathrm{m}):$ & 27.07 & 28.72 & 45.92 & 17.96 & 15.73 & 81.62 \\
\hline $\mathrm{D} 50(\mu \mathrm{m}):$ & 121.1 & 123.9 & 122.6 & 115.0 & 100.8 & 119.0 \\
\hline D90 $(\mu \mathrm{m}):$ & 177.2 & 177.1 & 170.9 & 169.4 & 158.5 & 170.4 \\
\hline (D90 / D10) $(\mu \mathrm{m}):$ & 6.547 & 6.167 & 3.722 & 9.431 & 10.08 & 2.087 \\
\hline (D90 - D10) $(\mu \mathrm{m}):$ & 150.1 & 148.4 & 125.0 & 151.4 & 142.8 & 88.74 \\
\hline (D75 / D25) $(\mu \mathrm{m}):$ & 1.742 & 1.651 & 1.500 & 1.667 & 2.130 & 1.479 \\
\hline$(\mathrm{D} 75-\mathrm{D} 25)(\mu \mathrm{m}):$ & 63.62 & 59.59 & 49.08 & 56.98 & 69.13 & 46.77 \\
\hline \% GRAVEL: & $0.0 \%$ & $0.0 \%$ & $0.0 \%$ & $0.0 \%$ & $0.0 \%$ & $0.0 \%$ \\
\hline \% SAND: & $82.9 \%$ & $84.6 \%$ & $89.5 \%$ & $82.0 \%$ & $74.6 \%$ & $95.8 \%$ \\
\hline \% MUD: & $17.1 \%$ & $15.4 \%$ & $10.5 \%$ & $18.0 \%$ & $25.4 \%$ & $4.2 \%$ \\
\hline
\end{tabular}




\begin{tabular}{|c|c|c|c|c|}
\hline & WS3-27.4A & WS3-28 & WS3-28.4 & WS3-28.8 \\
\hline TEXTURAL GROUP: & Muddy-sand & Muddy-sand & Muddy-sand & Sand \\
\hline SEDIMENT NAME: & $\begin{array}{c}\text { Very Coarse Silty Fine- } \\
\text { sand }\end{array}$ & Muddy Fine-sand & $\begin{array}{c}\text { Very Coarse Silty Fine- } \\
\text { sand }\end{array}$ & $\begin{array}{c}\text { Moderately Well-sorted } \\
\text { Fine-sand }\end{array}$ \\
\hline MEAN & 107.4 & 81.49 & 109.9 & 135.3 \\
\hline SORTING (std. dev.) & 63.42 & 69.03 & 53.86 & 50.12 \\
\hline SKEWNESS: & Very Fine Skewed & Very Fine Skewed & Very Fine Skewed & Very Fine Skewed \\
\hline MODE $1(\mu \mathrm{m})$ : & 140.3 & 140.3 & 127.8 & 140.3 \\
\hline MODE $2(\mu \mathrm{m}):$ & 45.80 & 0.756 & 45.80 & \\
\hline $\mathrm{D} 10(\mu \mathrm{m}):$ & 11.29 & 0.815 & 14.88 & 71.60 \\
\hline $\mathrm{D} 50(\mu \mathrm{m}):$ & 113.4 & 92.06 & 118.7 & 138.5 \\
\hline $\mathrm{D} 90(\mu \mathrm{m}):$ & 187.8 & 170.8 & 172.9 & 195.5 \\
\hline (D90 / D10) ( $\mu \mathrm{m}):$ & 16.63 & 209.6 & 11.63 & 2.731 \\
\hline (D90 - D10) ( $\mu \mathrm{m}):$ & 176.5 & 169.9 & 158.1 & 123.9 \\
\hline (D75 / D25) ( $\mu \mathrm{m}):$ & 2.857 & 38.93 & 1.753 & 1.533 \\
\hline (D75 - D25) ( $\mu \mathrm{m}):$ & 99.98 & 137.6 & 63.48 & 58.55 \\
\hline \% GRAVEL: & $0.0 \%$ & $0.0 \%$ & $0.0 \%$ & $0.0 \%$ \\
\hline \% SAND: & $72.9 \%$ & $55.8 \%$ & $80.5 \%$ & $91.6 \%$ \\
\hline \% MUD: & $27.1 \%$ & $44.2 \%$ & $19.5 \%$ & $8.4 \%$ \\
\hline
\end{tabular}




\begin{tabular}{|c|c|c|c|c|c|}
\hline & AB1-4 & AB1-5.6 & $A B 1-6.15$ & AB1-7 & AB1-7.6 \\
\hline TEXTURAL GROUP: & Muddy-sand & Sand & Sand & Muddy-sand & Sand \\
\hline SEDIMENT NAME: & $\begin{array}{l}\text { Medium Silty Fine- } \\
\text { sand }\end{array}$ & Well-sorted Fine-sand & $\begin{array}{l}\text { Moderately-sorted } \\
\text { Fine-sand }\end{array}$ & $\begin{array}{l}\text { Very Coarse Silty Fine- } \\
\text { sand }\end{array}$ & $\begin{array}{l}\text { Moderately-sorted Fine- } \\
\text { sand }\end{array}$ \\
\hline MEAN & 146.2 & 167.4 & 194.2 & 136.4 & 211.5 \\
\hline SORTING (std. dev.) & 68.78 & 53.37 & 102.1 & 129.6 & 117.8 \\
\hline SKEWNESS: & Very Fine Skewed & Fine Skewed & Fine Skewed & Very Fine Skewed & Fine Skewed \\
\hline MODE $1(\mu \mathrm{m}):$ & 203.7 & 185.5 & 185.5 & 185.5 & 203.7 \\
\hline MODE $2(\mu \mathrm{m}):$ & & & 471.7 & 45.80 & 471.7 \\
\hline D10 $(\mu \mathrm{m}):$ & 16.23 & 100.3 & 94.23 & 6.196 & 88.43 \\
\hline D50 $(\mu \mathrm{m}):$ & 163.7 & 169.9 & 180.0 & 116.1 & 191.6 \\
\hline D90 $(\mu \mathrm{m}):$ & 219.3 & 232.2 & 299.8 & 292.2 & 378.1 \\
\hline (D90 / D10) ( $\mu \mathrm{m}):$ & 13.52 & 2.314 & 3.182 & 47.16 & 4.275 \\
\hline (D90 - D10) $(\mu \mathrm{m}):$ & 203.1 & 131.8 & 205.6 & 286.0 & 289.7 \\
\hline (D75 / D25) $(\mu \mathrm{m}):$ & 1.678 & 1.475 & 1.640 & 8.287 & 1.747 \\
\hline (D75 - D25) $(\mu \mathrm{m}):$ & 79.45 & 65.39 & 89.61 & 175.9 & 108.1 \\
\hline \% GRAVEL: & $0.0 \%$ & $0.0 \%$ & $0.0 \%$ & $0.0 \%$ & $0.0 \%$ \\
\hline \% SAND: & $82.8 \%$ & $95.6 \%$ & $93.1 \%$ & $61.8 \%$ & $92.2 \%$ \\
\hline \% MUD: & $17.2 \%$ & $4.4 \%$ & $6.9 \%$ & $38.2 \%$ & $7.8 \%$ \\
\hline
\end{tabular}




\begin{tabular}{|c|c|c|c|c|}
\hline & AB1-8.5 & $A B 1-11 A$ & $A B 1-11 B$ & AB1-11C \\
\hline TEXTURAL GROUP: & Muddy-sand & Muddy-sand & Muddy-sand & Muddy-sand \\
\hline SEDIMENT NAME: & $\begin{array}{c}\text { Very Coarse Silty } \\
\text { Fine-sand }\end{array}$ & $\begin{array}{c}\text { Very Coarse Silty Fine- } \\
\text { sand }\end{array}$ & $\begin{array}{l}\text { Very Coarse Silty } \\
\text { Fine-sand }\end{array}$ & $\begin{array}{c}\text { Very Coarse Silty Fine- } \\
\text { sand }\end{array}$ \\
\hline MEAN & 110.8 & 116.9 & 118.3 & 119.8 \\
\hline SORTING (std. dev.) & 91.96 & 71.12 & 69.98 & 69.19 \\
\hline SKEWNESS: & Very Fine Skewed & Very Fine Skewed & Very Fine Skewed & Very Fine Skewed \\
\hline MODE $1(\mu \mathrm{m})$ : & 169.0 & 169.0 & 169.0 & 169.0 \\
\hline MODE $2(\mu \mathrm{m}):$ & 45.80 & & & \\
\hline D10 $(\mu \mathrm{m}):$ & 5.149 & 7.774 & 8.991 & 10.21 \\
\hline D50 $(\mu \mathrm{m}):$ & 111.2 & 129.8 & 130.2 & 131.5 \\
\hline D90 $(\mu \mathrm{m}):$ & 212.4 & 203.3 & 203.3 & 203.5 \\
\hline (D90 / D10) $(\mu \mathrm{m}):$ & 41.26 & 26.15 & 22.61 & 19.93 \\
\hline (D90 - D10) $(\mu \mathrm{m}):$ & 207.3 & 195.5 & 194.3 & 193.3 \\
\hline (D75 / D25) ( $\mu \mathrm{m}):$ & 6.766 & 3.537 & 3.072 & 2.771 \\
\hline (D75 - D25) $(\mu \mathrm{m}):$ & 144.7 & 122.1 & 114.8 & 109.0 \\
\hline \% GRAVEL: & $0.0 \%$ & $0.0 \%$ & $0.0 \%$ & $0.0 \%$ \\
\hline \% SAND: & $62.9 \%$ & $72.5 \%$ & $73.8 \%$ & $74.9 \%$ \\
\hline \% MUD: & $37.1 \%$ & $27.5 \%$ & $26.2 \%$ & $25.1 \%$ \\
\hline
\end{tabular}




\begin{tabular}{|c|c|c|c|c|}
\hline & AB2-3.4 & AB2-4.4 & AB2-5.2 & AB2-5.7 \\
\hline TEXTURAL GROUP: & Muddy-sand & Muddy-sand & Muddy-sand & Muddy-sand \\
\hline SEDIMENT NAME: & Very Coarse Silty Fine-sand & Very Coarse Silty Fine-sand & Very Coarse Silty Fine-sand & Very Coarse Silty Fine-sand \\
\hline MEAN & 153.0 & 114.0 & 174.5 & 162.5 \\
\hline SORTING (std. dev.) & 83.06 & 76.79 & 102.6 & 85.65 \\
\hline SKEWNESS: & Very Fine Skewed & Very Fine Skewed & Very Fine Skewed & Very Fine Skewed \\
\hline MODE $1(\mu \mathrm{m})$ : & 203.7 & 169.0 & 203.7 & 185.5 \\
\hline D10 $(\mu \mathrm{m}):$ & 16.88 & 6.725 & 23.23 & 26.15 \\
\hline D50 ( $\mu \mathrm{m}):$ & 168.9 & 127.8 & 177.3 & 168.6 \\
\hline D90 ( $\mu \mathrm{m}):$ & 251.3 & 210.1 & 272.1 & 254.4 \\
\hline (D90 / D10) ( $\mu \mathrm{m}):$ & 14.89 & 31.24 & 11.71 & 9.728 \\
\hline (D90 - D10) $(\mu \mathrm{m}):$ & 234.5 & 203.4 & 248.9 & 228.2 \\
\hline (D75 / D25) ( $\mu \mathrm{m}):$ & 2.373 & 5.224 & 1.797 & 1.754 \\
\hline (D75 - D25) $(\mu \mathrm{m}):$ & 124.0 & 141.8 & 99.19 & 91.22 \\
\hline \% GRAVEL: & $0.0 \%$ & $0.0 \%$ & $0.0 \%$ & $0.0 \%$ \\
\hline \% SAND: & $79.2 \%$ & $66.9 \%$ & $83.1 \%$ & $84.4 \%$ \\
\hline \% MUD: & $20.8 \%$ & $33.1 \%$ & $16.9 \%$ & $15.6 \%$ \\
\hline
\end{tabular}




\begin{tabular}{|c|c|c|c|c|}
\hline & AB2-6.1 & AB2-6.7 & AB2-7.3 & AB2-8.3 \\
\hline TEXTURAL GROUP: & Muddy-sand & Muddy-sand & Muddy-sand & Muddy-sand \\
\hline SEDIMENT NAME: & Very Coarse Silty Fine-sand & Very Coarse Silty Fine-sand & Very Coarse Silty Fine-sand & Very Coarse Silty Fine-sand \\
\hline MEAN & 193.3 & 240.1 & 190.7 & 187.9 \\
\hline SORTING (std. dev.) & 137.6 & 279.1 & 107.4 & 192.9 \\
\hline SKEWNESS: & Very Fine Skewed & Very Fine Skewed & Very Fine Skewed & Very Fine Skewed \\
\hline MODE $1(\mu \mathrm{m}):$ & 203.7 & 185.5 & 203.7 & 185.5 \\
\hline MODE $2(\mu \mathrm{m}):$ & & 517.8 & 471.7 & 471.7 \\
\hline D10 $(\mu \mathrm{m}):$ & 23.58 & 23.01 & 46.03 & 13.00 \\
\hline D50 $(\mu \mathrm{m}):$ & 178.9 & 174.9 & 184.0 & 151.1 \\
\hline $\mathrm{D} 90(\mu \mathrm{m}):$ & 373.1 & 512.0 & 306.1 & 443.5 \\
\hline (D90 / D10) $(\mu \mathrm{m}):$ & 15.82 & 22.25 & 6.650 & 34.11 \\
\hline (D90 - D10) $(\mu \mathrm{m}):$ & 349.5 & 489.0 & 260.0 & 430.5 \\
\hline (D75 / D25) ( $\mu \mathrm{m}):$ & 2.617 & 2.543 & 1.744 & 4.590 \\
\hline$(\mathrm{D} 75$ - D25) $(\mu \mathrm{m}):$ & 156.5 & 152.4 & 100.4 & 180.7 \\
\hline \% GRAVEL: & $0.0 \%$ & $0.0 \%$ & $0.0 \%$ & $0.0 \%$ \\
\hline \% SAND: & $81.0 \%$ & $80.6 \%$ & $87.7 \%$ & $71.7 \%$ \\
\hline \% MUD: & $19.0 \%$ & $19.4 \%$ & $12.3 \%$ & $28.3 \%$ \\
\hline
\end{tabular}




\begin{tabular}{|c|c|c|c|c|c|c|}
\hline & AB3-3.53 & AB3-4 & AB3-4.9 & AB3-5.6 & AB3-6.1 & AB3-7 \\
\hline TEXTURAL GROUP: & Muddy-sand & Muddy-sand & Muddy-sand & Sandy Mud & Muddy-sand & Muddy-sand \\
\hline SEDIMENT NAME: & $\begin{array}{l}\text { Very Coarse Silty } \\
\text { Fine-sand }\end{array}$ & $\begin{array}{l}\text { Very Coarse Silty } \\
\text { Fine-sand }\end{array}$ & $\begin{array}{l}\text { Very Coarse Silty } \\
\text { Fine-sand }\end{array}$ & $\begin{array}{c}\text { Fine-sandy Very } \\
\text { Coarse Silt }\end{array}$ & $\begin{array}{l}\text { Very Coarse Silty } \\
\text { Fine-sand }\end{array}$ & $\begin{array}{c}\text { Very Coarse Silty } \\
\text { Fine-sand }\end{array}$ \\
\hline MEAN & 84.48 & 96.89 & 107.6 & 68.17 & 179.0 & 84.21 \\
\hline SORTING (std. dev.) & 63.58 & 64.71 & 67.28 & 61.00 & 77.21 & 67.95 \\
\hline SKEWNESS: & Very Fine Skewed & Very Fine Skewed & Very Fine Skewed & Very Fine Skewed & Very Fine Skewed & Very Fine Skewed \\
\hline MODE $1(\mu \mathrm{m}):$ & 140.3 & 154.0 & 154.0 & 140.3 & 223.7 & 169.0 \\
\hline MODE $2(\mu \mathrm{m}):$ & 60.59 & 66.52 & & 60.59 & & 73.03 \\
\hline MODE $3(\mu \mathrm{m})$ : & & & & 38.01 & & 16.41 \\
\hline $\mathrm{D} 10(\mu \mathrm{m}):$ & 3.816 & 5.907 & 5.408 & 2.642 & 35.99 & 5.862 \\
\hline D50 $(\mu \mathrm{m}):$ & 95.84 & 117.7 & 134.1 & 49.22 & 191.0 & 67.01 \\
\hline $\mathrm{D} 90(\mu \mathrm{m}):$ & 163.6 & 173.3 & 180.5 & 154.2 & 266.7 & 179.9 \\
\hline (D90 / D10) $(\mu \mathrm{m}):$ & 42.87 & 29.33 & 33.37 & 58.39 & 7.409 & 30.69 \\
\hline (D90 - D10) $(\mu \mathrm{m}):$ & 159.8 & 167.4 & 175.1 & 151.6 & 230.7 & 174.1 \\
\hline (D75 / D25) ( $\mu \mathrm{m}):$ & 9.926 & 5.585 & 5.218 & 15.41 & 1.595 & 8.118 \\
\hline (D75 - D25) ( $\mu \mathrm{m}):$ & 126.5 & 124.0 & 129.4 & 119.6 & 86.97 & 129.6 \\
\hline \% GRAVEL: & $0.0 \%$ & $0.0 \%$ & $0.0 \%$ & $0.0 \%$ & $0.0 \%$ & $0.0 \%$ \\
\hline \% SAND: & $56.8 \%$ & $63.1 \%$ & $67.8 \%$ & $45.2 \%$ & $87.7 \%$ & $51.8 \%$ \\
\hline \% MUD: & $43.2 \%$ & $36.9 \%$ & $32.2 \%$ & $54.8 \%$ & $12.3 \%$ & $48.2 \%$ \\
\hline
\end{tabular}




\begin{tabular}{|c|c|c|c|c|c|c|}
\hline & AB3-7.6 & AB3-8.3 & AB3-10 & AB3-11.5a & $A B 3-11.5 b$ & AB3-13 \\
\hline TEXTURAL GROUP: & Muddy-sand & Sand & Muddy-sand & Sand & Sand & Muddy-sand \\
\hline SEDIMENT NAME: & $\begin{array}{l}\text { Very Coarse Silty } \\
\text { Fine-sand }\end{array}$ & $\begin{array}{l}\text { Moderately Well- } \\
\text { sorted Fine-sand }\end{array}$ & $\begin{array}{l}\text { Very Coarse Silty } \\
\text { Fine-sand }\end{array}$ & $\begin{array}{l}\text { Moderately-sorted } \\
\text { Fine-sand }\end{array}$ & $\begin{array}{l}\text { Moderately- } \\
\text { sorted Fine-sand }\end{array}$ & $\begin{array}{l}\text { Very Coarse Silty } \\
\text { Fine-sand }\end{array}$ \\
\hline MEAN & 226.2 & 155.7 & 126.1 & 147.4 & 145.8 & 115.7 \\
\hline SORTING (std. dev.) & 183.9 & 58.00 & 111.5 & 54.82 & 53.85 & 59.67 \\
\hline SKEWNESS: & Very Fine Skewed & Very Fine Skewed & $\begin{array}{l}\text { Very Fine } \\
\text { Skewed }\end{array}$ & Very Fine Skewed & Very Fine Skewed & Very Fine Skewed \\
\hline MODE $1(\mu \mathrm{m}):$ & 203.7 & 169.0 & 169.0 & 169.0 & 169.0 & 154.0 \\
\hline D10 $(\mu \mathrm{m}):$ & 38.14 & 78.05 & 6.075 & 65.49 & 63.87 & 30.92 \\
\hline D50 $(\mu \mathrm{m}):$ & 189.2 & 156.9 & 117.9 & 155.2 & 154.6 & 117.5 \\
\hline $\mathrm{D} 90(\mu \mathrm{m}):$ & 449.3 & 228.9 & 233.2 & 208.7 & 205.1 & 192.9 \\
\hline (D90 / D10) $(\mu \mathrm{m}):$ & 11.78 & 2.932 & 38.38 & 3.187 & 3.211 & 6.239 \\
\hline (D90 - D10) $(\mu \mathrm{m}):$ & 411.1 & 150.8 & 227.1 & 143.2 & 141.2 & 162.0 \\
\hline (D75 / D25) $(\mu \mathrm{m}):$ & 2.224 & 1.568 & 4.879 & 1.494 & 1.480 & 2.238 \\
\hline$(D 75-D 25)(\mu \mathrm{m}):$ & 150.4 & 70.04 & 139.0 & 61.15 & 59.29 & 88.11 \\
\hline \% GRAVEL: & $0.0 \%$ & $0.0 \%$ & $0.0 \%$ & $0.0 \%$ & $0.0 \%$ & $0.0 \%$ \\
\hline \% SAND: & $85.0 \%$ & $92.7 \%$ & $67.3 \%$ & $90.4 \%$ & $90.2 \%$ & $78.8 \%$ \\
\hline \% MUD: & $15.0 \%$ & $7.3 \%$ & $32.7 \%$ & $9.6 \%$ & $9.8 \%$ & $21.2 \%$ \\
\hline
\end{tabular}




\begin{tabular}{|c|c|c|c|c|}
\cline { 2 - 5 } \multicolumn{1}{c|}{} & AB3-14.5 & AB3-16 & AB3-17.5 & AB3-19 \\
\hline TEXTURAL GROUP: & Sand & Muddy-sand & Muddy-sand & Muddy-sand \\
\hline SEDIMENT NAME: & $\begin{array}{c}\text { Moderately Well- } \\
\text { sorted Fine-sand }\end{array}$ & $\begin{array}{c}\text { Very Coarse Silty } \\
\text { Fine-sand }\end{array}$ & $\begin{array}{c}\text { Very Coarse Silty } \\
\text { Fine-sand }\end{array}$ & $\begin{array}{c}\text { Very Coarse Silty } \\
\text { Fine-sand }\end{array}$ \\
\hline MEAN & 143.2 & 121.4 & 127.7 & 150.5 \\
\hline SORTING (std. dev.) & 55.82 & 56.44 & 57.38 & 88.79 \\
\hline SKEWNESS: & Very Fine Skewed & Very Fine Skewed & Very Fine Skewed & Very Fine Skewed \\
\hline MODE 1 $(\mu \mathrm{m}):$ & 154.0 & 169.0 & 169.0 & 169.0 \\
\hline D10 $(\mu \mathrm{m}):$ & 64.96 & 39.71 & 35.09 & 19.85 \\
\hline D50 ( $\mu \mathrm{m}):$ & 146.7 & 125.7 & 138.0 & 152.7 \\
\hline D90 $(\mu \mathrm{m}):$ & 212.0 & 193.5 & 194.4 & 243.9 \\
\hline (D90 / D10) $(\mu \mathrm{m}):$ & 3.263 & 4.873 & 5.541 & 12.28 \\
\hline (D90 - D10) $(\mu \mathrm{m}):$ & 147.0 & 153.8 & 159.3 & 224.0 \\
\hline (D75 / D25) $(\mu \mathrm{m}):$ & 1.620 & 2.025 & 1.872 & 1.968 \\
\hline (D75 - D25) $(\mu \mathrm{m}):$ & 69.27 & 83.46 & 79.45 & 97.21 \\
\hline \% GRAVEL: & $0.0 \%$ & $0.0 \%$ & $0.0 \%$ & $0.0 \%$ \\
\hline \% SAND: & $90.5 \%$ & $83.0 \%$ & $17.0 \%$ & $82.6 \%$ \\
\hline \% MUD: & $9.5 \%$ & & & $17.4 \%$ \\
\hline
\end{tabular}




\begin{tabular}{|c|c|c|c|c|}
\hline & AB4-3.4 & AB4-4.5 & AB4-5.9 & AB4-6.4 \\
\hline TEXTURAL GROUP: & Muddy-sand & Muddy-sand & Muddy-sand & Sand \\
\hline SEDIMENT NAME: & Very Coarse Silty Fine-sand & Very Coarse Silty Fine-sand & Very Coarse Silty Fine-sand & $\begin{array}{l}\text { Moderately-sorted Fine- } \\
\text { sand }\end{array}$ \\
\hline MEAN & 155.5 & 145.3 & 121.0 & 260.5 \\
\hline SORTING (std. dev.) & 60.46 & 68.10 & 78.24 & 135.4 \\
\hline SKEWNESS: & Very Fine Skewed & Very Fine Skewed & Very Fine Skewed & Fine Skewed \\
\hline MODE $1(\mu \mathrm{m})$ : & 169.0 & 203.7 & 185.5 & 223.7 \\
\hline MODE $2(\mu \mathrm{m}):$ & & & 80.17 & \\
\hline D10 $(\mu \mathrm{m}):$ & 56.94 & 20.21 & 9.331 & 128.8 \\
\hline D50 $(\mu \mathrm{m}):$ & 162.5 & 162.3 & 140.2 & 232.3 \\
\hline $\mathrm{D} 90(\mu \mathrm{m}):$ & 225.6 & 219.4 & 215.6 & 462.4 \\
\hline (D90 / D10) ( $\mu \mathrm{m}):$ & 3.962 & 10.86 & 23.11 & 3.589 \\
\hline (D90 - D10) $(\mu \mathrm{m}):$ & 168.7 & 199.2 & 206.3 & 333.5 \\
\hline (D75 / D25) ( $\mu \mathrm{m}):$ & 1.518 & 1.746 & 4.512 & 1.859 \\
\hline (D75 - D25) $(\mu \mathrm{m}):$ & 66.64 & 83.78 & 144.1 & 150.3 \\
\hline \% GRAVEL: & $0.0 \%$ & $0.0 \%$ & $0.0 \%$ & $0.0 \%$ \\
\hline$\%$ SAND: & $89.9 \%$ & $83.1 \%$ & $68.4 \%$ & $94.4 \%$ \\
\hline \% MUD: & $10.1 \%$ & $16.9 \%$ & $31.6 \%$ & $5.6 \%$ \\
\hline
\end{tabular}




\begin{tabular}{|c|c|c|c|c|}
\hline & AB4-7 & AB4-7.7 & AB4-8.5 & AB4-9.5 \\
\hline TEXTURAL GROUP: & Muddy-sand & Muddy-sand & Sand & Sand \\
\hline SEDIMENT NAME: & Very Coarse Silty Fine-sand & Very Coarse Silty Fine-sand & $\begin{array}{l}\text { Moderately Well-sorted } \\
\text { Fine-sand }\end{array}$ & Moderately-sorted Fine-sano \\
\hline MEAN & 208.3 & 214.8 & 242.7 & 214.3 \\
\hline SORTING (std. dev.) & 129.9 & 203.6 & 104.3 & 112.3 \\
\hline SKEWNESS: & Very Fine Skewed & Very Fine Skewed & Symmetrical & Fine Skewed \\
\hline MODE $1(\mu \mathrm{m})$ : & 203.7 & 203.7 & 223.7 & 203.7 \\
\hline MODE $2(\mu \mathrm{m}):$ & 471.7 & 517.8 & & 471.7 \\
\hline $\mathrm{D} 10(\mu \mathrm{m}):$ & 38.96 & 16.47 & 139.8 & 108.5 \\
\hline $\mathrm{D} 50(\mu \mathrm{m}):$ & 192.0 & 184.5 & 227.8 & 195.4 \\
\hline $\mathrm{D} 90(\mu \mathrm{m}):$ & 392.8 & 452.6 & 374.0 & 354.2 \\
\hline (D90 / D10) $(\mu \mathrm{m}):$ & 10.08 & 27.49 & 2.676 & 3.265 \\
\hline (D90 - D10) $(\mu \mathrm{m}):$ & 353.8 & 436.1 & 234.2 & 245.7 \\
\hline (D75 / D25) ( $\mu \mathrm{m}):$ & 1.814 & 3.914 & 1.603 & 1.644 \\
\hline (D75 - D25) $(\mu \mathrm{m}):$ & 113.5 & 194.3 & 108.5 & 98.15 \\
\hline \% GRAVEL: & $0.0 \%$ & $0.0 \%$ & $0.0 \%$ & $0.0 \%$ \\
\hline \% SAND: & $87.1 \%$ & $75.7 \%$ & $96.5 \%$ & $93.9 \%$ \\
\hline \% MUD: & $12.9 \%$ & $24.3 \%$ & $3.5 \%$ & $6.1 \%$ \\
\hline
\end{tabular}




\begin{tabular}{|c|c|c|c|c|c|}
\hline & Transect-TS1 & Transect-TS2 & Transect-TS3 & Transect-TS4 & Transect-TS5 \\
\hline TEXTURAL GROUP: & Sand & Sand & Sand & Sand & Sand \\
\hline SEDIMENT NAME: & Well-sorted Fine-sand & Well-sorted Fine-sand & $\begin{array}{l}\text { Well-sorted Fine- } \\
\text { sand }\end{array}$ & $\begin{array}{l}\text { Very Well-sorted Fine- } \\
\text { sand }\end{array}$ & $\begin{array}{l}\text { Well-sorted Fine- } \\
\text { sand }\end{array}$ \\
\hline MEAN & 173.3 & 181.2 & 183.0 & 181.7 & 189.6 \\
\hline SORTING (std. dev.) & 52.85 & 48.66 & 45.31 & 41.23 & \\
\hline SKEWNESS: & Symmetrical & Symmetrical & Symmetrical & Symmetrical & Symmetrical \\
\hline MODE $1(\mu \mathrm{m}):$ & 169.0 & 169.0 & 185.5 & 169.0 & 185.5 \\
\hline $\mathrm{D} 10(\mu \mathrm{m}):$ & 117.1 & 124.2 & 128.5 & 130.2 & 134.3 \\
\hline $\mathrm{D} 50(\mu \mathrm{m}):$ & 171.6 & 177.7 & 178.9 & 177.5 & 185.1 \\
\hline D90 $(\mu \mathrm{m}):$ & 240.4 & 247.0 & 245.4 & 239.3 & 251.6 \\
\hline (D90 / D10) ( $\mu \mathrm{m}):$ & 2.052 & 1.988 & 1.910 & 1.838 & 1.873 \\
\hline (D90 - D10) ( $\mu \mathrm{m}):$ & 123.2 & 122.7 & 116.9 & 109.1 & 117.3 \\
\hline (D75 / D25) ( $\mu \mathrm{m}):$ & 1.460 & 1.436 & 1.414 & 1.391 & 1.410 \\
\hline (D75 - D25) ( $\mu \mathrm{m}):$ & 65.08 & 64.56 & 62.22 & 58.71 & 63.77 \\
\hline \% GRAVEL: & $0.0 \%$ & $0.0 \%$ & $0.0 \%$ & $0.0 \%$ & $0.0 \%$ \\
\hline \% SAND: & $96.6 \%$ & $99.1 \%$ & $99.6 \%$ & $100.0 \%$ & $100.0 \%$ \\
\hline \% MUD: & $3.4 \%$ & $0.9 \%$ & $0.4 \%$ & $0.0 \%$ & $0.0 \%$ \\
\hline
\end{tabular}




\begin{tabular}{|c|c|c|c|c|c|}
\hline & Transect-TS6 & Transect-TS7 & Transect-TS8 & Transect-TS9 & Transect-TS10 \\
\hline TEXTURAL GROUP: & Sand & Sand & Sand & Sand & Sand \\
\hline SEDIMENT NAME: & $\begin{array}{c}\text { Very Well-sorted Fine- } \\
\text { sand }\end{array}$ & $\begin{array}{l}\text { Very Well-sorted Fine- } \\
\text { sand }\end{array}$ & $\begin{array}{l}\text { Very Well-sorted Fine- } \\
\text { sand }\end{array}$ & $\begin{array}{l}\text { Very Well-sorted Fine- } \\
\text { sand }\end{array}$ & $\begin{array}{l}\text { Very Well-sorted } \\
\text { Fine-sand }\end{array}$ \\
\hline MEAN & 178.6 & 183.0 & 178.8 & 176.8 & 183.8 \\
\hline SORTING (std. dev.) & 39.44 & 41.96 & 40.02 & 37.94 & 41.33 \\
\hline SKEWNESS: & Symmetrical & Symmetrical & Symmetrical & Symmetrical & Symmetrical \\
\hline MODE $1(\mu \mathrm{m}):$ & 169.0 & 185.5 & 169.0 & 169.0 & 185.5 \\
\hline D10 $(\mu \mathrm{m}):$ & 128.8 & 130.3 & 128.3 & 128.4 & 131.9 \\
\hline $\mathrm{D} 50(\mu \mathrm{m}):$ & 174.8 & 178.8 & 174.9 & 173.5 & 179.9 \\
\hline $\mathrm{D} 90(\mu \mathrm{m}):$ & 233.0 & 241.8 & 233.8 & 229.7 & 241.5 \\
\hline (D90 / D10) $(\mu \mathrm{m}):$ & 1.809 & 1.856 & 1.822 & 1.789 & 1.831 \\
\hline (D90 - D10) $(\mu \mathrm{m}):$ & 104.2 & 111.5 & 105.5 & 101.3 & 109.6 \\
\hline (D75 / D25) ( $\mu \mathrm{m}):$ & 1.381 & 1.397 & 1.387 & 1.371 & 1.388 \\
\hline (D75 - D25) ( $\mu \mathrm{m}):$ & 56.65 & 59.96 & 57.38 & 54.94 & 59.08 \\
\hline \% GRAVEL: & $0.0 \%$ & $0.0 \%$ & $0.0 \%$ & $0.0 \%$ & $0.0 \%$ \\
\hline \% SAND: & $100.0 \%$ & $100.0 \%$ & $100.0 \%$ & $100.0 \%$ & $100.0 \%$ \\
\hline \% MUD: & $0.0 \%$ & $0.0 \%$ & $0.0 \%$ & $0.0 \%$ & $0.0 \%$ \\
\hline
\end{tabular}




\begin{tabular}{|c|c|c|c|c|}
\hline & Transect-TS11 & Transect-TS12 & Transect-TS13 & Transect-TS14 \\
\hline TEXTURAL GROUP: & Sand & Sand & Sand & Sand \\
\hline SEDIMENT NAME: & Well-sorted Fine-sand & Very Well-sorted Fine-sand & Very Well-sorted Fine-sand & $\begin{array}{c}\text { Very Well-sorted Fine- } \\
\text { sand }\end{array}$ \\
\hline MEAN & 196.1 & 183.1 & 183.6 & 184.8 \\
\hline SORTING (std. dev.) & 46.78 & 41.44 & 41.30 & 41.81 \\
\hline SKEWNESS: & Symmetrical & Symmetrical & Symmetrical & Symmetrical \\
\hline MODE $1(\mu \mathrm{m}):$ & 203.7 & 185.5 & 185.5 & 185.5 \\
\hline $\mathrm{D} 10(\mu \mathrm{m}):$ & 137.6 & 131.4 & 132.0 & 132.5 \\
\hline $\mathrm{D} 50(\mu \mathrm{m}):$ & 191.2 & 179.0 & 179.5 & 180.7 \\
\hline D90 (m): & 261.1 & 241.0 & 241.4 & 243.4 \\
\hline (D90 / D10) $(\mu \mathrm{m}):$ & 1.897 & 1.835 & 1.828 & 1.837 \\
\hline (D90 - D10) $(\mu \mathrm{m}):$ & 123.4 & 109.6 & 109.4 & 110.9 \\
\hline (D75 / D25) ( $\mu \mathrm{m}):$ & 1.413 & 1.390 & 1.388 & 1.391 \\
\hline (D75 - D25) ( $\mu \mathrm{m}):$ & 66.46 & 59.08 & 58.96 & 59.72 \\
\hline \% GRAVEL: & $0.0 \%$ & $0.0 \%$ & $0.0 \%$ & $0.0 \%$ \\
\hline \% SAND: & $100.0 \%$ & $100.0 \%$ & $100.0 \%$ & $100.0 \%$ \\
\hline \% MUD: & $0.0 \%$ & $0.0 \%$ & $0.0 \%$ & $0.0 \%$ \\
\hline
\end{tabular}




\section{Appendix 2: Point Counting}

Point counting data for the samples collected from the $A B 1, A B 2$ and $A B 4$ cores as well as the transect samples is presented in this section. The data from the Wharemauku cores is presented below. A table of this data is presented on page 158 , while the data from the transect is presented on page 159.
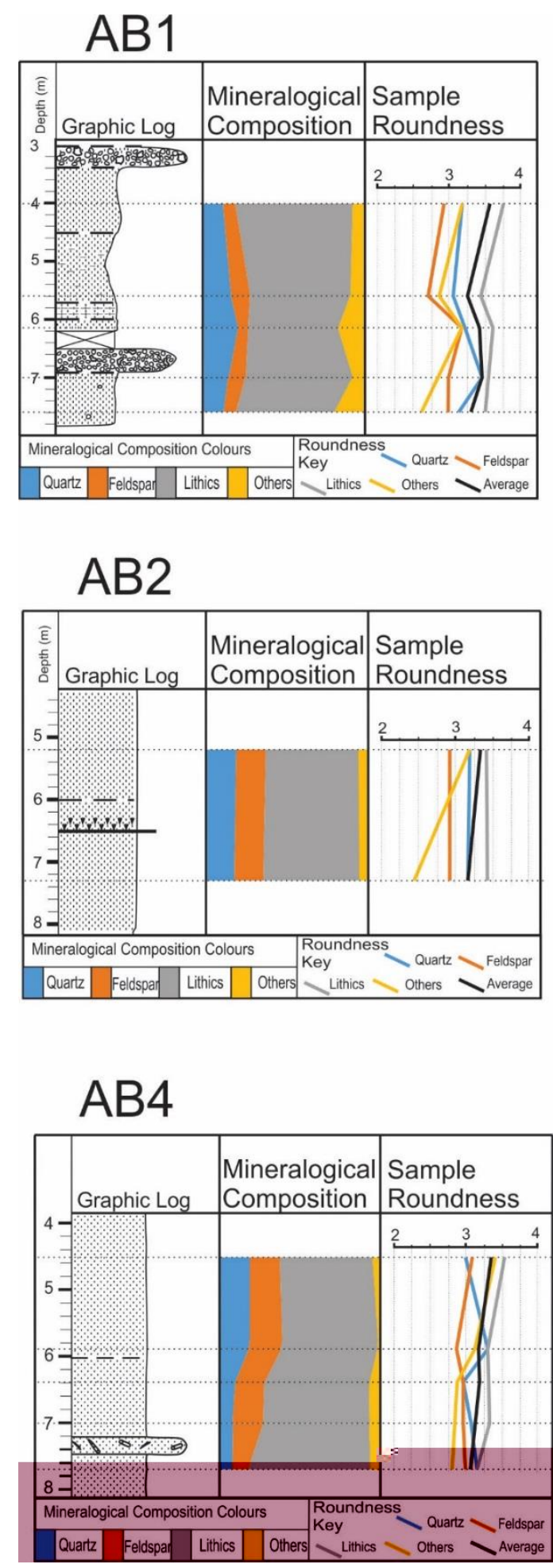
AB1

AB2

AB4

\begin{tabular}{|c|c|c|c|c|c|c|c|c|c|c|c|}
\hline 4 & Roundness & $\begin{array}{l}\text { Grain } \\
\text { counts }\end{array}$ & $\%$ & 5.2 & Roundness & $\begin{array}{l}\text { Grain } \\
\text { counts }\end{array}$ & $\%$ & 4.5 & Roundness & $\begin{array}{l}\text { Grain } \\
\text { counts }\end{array}$ & $\%$ \\
\hline Quartz & 3.19 & 37 & $12.33 \%$ & Quartz & 3.21 & 56 & $18.67 \%$ & Quartz & 3.00 & 57 & $19.00 \%$ \\
\hline Feldspar & 2.87 & 23 & $7.67 \%$ & Feldspar & 2.95 & 55 & $18.33 \%$ & Feldspar & 3.06 & 54 & $18.00 \%$ \\
\hline Lithics & 3.74 & 219 & $73.00 \%$ & Lithics & 3.43 & 171 & $57.00 \%$ & Lithics & 3.53 & 171 & $57.00 \%$ \\
\hline Other & 3.19 & 21 & $7.00 \%$ & Other & 3.22 & 18 & $6.00 \%$ & Other & 3.39 & 18 & $6.00 \%$ \\
\hline Total & 3.57 & 300 & & Total & 3.29 & 300 & & Total & 3.33 & 300 & \\
\hline
\end{tabular}

\begin{tabular}{|l|r|r|l|l|r|r|r|l|r|r|r|}
\hline 5.6 & Roundness & $\begin{array}{l}\text { Grain } \\
\text { counts }\end{array}$ & $\%$ & 7.3 & Roundness & $\begin{array}{l}\text { Grain } \\
\text { counts }\end{array}$ & $\%$ & 5.9 & Roundness & $\begin{array}{l}\text { Grain } \\
\text { counts }\end{array}$ & $\%$ \\
\hline Quartz & 3.06 & 53 & $17.67 \%$ & Quartz & 3.17 & 52 & $17.33 \%$ & Quartz & 3.28 & 57 & $19.00 \%$ \\
\hline Feldspar & 2.69 & 35 & $11.67 \%$ & Feldspar & 2.92 & 53 & $17.67 \%$ & Feldspar & 2.85 & 60 & $20.00 \%$ \\
\hline Lithics & 3.45 & 187 & $62.33 \%$ & Lithics & 3.42 & 177 & $59.00 \%$ & Lithics & 3.27 & 175 & $58.33 \%$ \\
\hline Other & 2.84 & 25 & $8.33 \%$ & Other & 2.44 & 18 & $6.00 \%$ & Other & 3.13 & 8 & $2.67 \%$ \\
\hline Total & 3.24 & 300 & & Total & 3.23 & 300 & & Total & 3.19 & 300 & \\
\hline
\end{tabular}

\begin{tabular}{|l|r|r|l|}
\hline \multicolumn{1}{|r|}{6.15} & Roundness & $\begin{array}{l}\text { Grain } \\
\text { counts }\end{array}$ & \multicolumn{1}{l|}{$\%$} \\
\hline Quartz & 3.23 & 66 & $22.00 \%$ \\
\hline Feldspar & 3.21 & 19 & $6.33 \%$ \\
\hline Lithics & 3.59 & 167 & $55.67 \%$ \\
\hline Other & 3.21 & 48 & $16.00 \%$ \\
\hline Total & 3.42 & 300 & \\
\hline
\end{tabular}

\begin{tabular}{|l|r|r|l|}
\hline 6.4 & Roundness & $\begin{array}{l}\text { Grain } \\
\text { counts }\end{array}$ & \multicolumn{1}{l|}{$\%$} \\
\hline Quartz & 2.94 & 32 & $10.67 \%$ \\
\hline Feldspar & 2.94 & 54 & $18.00 \%$ \\
\hline Lithics & 3.32 & 193 & $64.33 \%$ \\
\hline Other & 2.86 & 21 & $7.00 \%$ \\
\hline Total & 3.18 & 300 & \\
\hline
\end{tabular}

\begin{tabular}{|l|r|r|l|}
\hline & \multicolumn{1}{|l|}{ Roundness } & $\begin{array}{l}\text { Grain } \\
\text { counts }\end{array}$ & \multicolumn{1}{l|}{} \\
\hline Quartz & 3.44 & 48 & $16.00 \%$ \\
\hline Feldspar & 3.03 & 31 & $10.33 \%$ \\
\hline Lithics & 3.53 & 200 & $66.67 \%$ \\
\hline Other & 2.86 & 21 & $7.00 \%$ \\
\hline Total & 3.42 & 300 & \\
\hline
\end{tabular}

\begin{tabular}{|l|r|r|l|}
\hline 7 & Roundness & $\begin{array}{l}\text { Grain } \\
\text { counts }\end{array}$ & \multicolumn{1}{l|}{$\%$} \\
\hline Quartz & 3.07 & 28 & $9.33 \%$ \\
\hline Feldspar & 2.93 & 55 & $18.33 \%$ \\
\hline Lithics & 3.28 & 197 & $65.67 \%$ \\
\hline Other & 2.80 & 20 & $6.67 \%$ \\
\hline Total & 3.17 & 300 & \\
\hline
\end{tabular}

\begin{tabular}{|l|r|r|l|}
\hline 7.6 & Roundness & $\begin{array}{l}\text { Grain } \\
\text { counts }\end{array}$ & \multicolumn{1}{l|}{$\%$} \\
\hline Quartz & 3.13 & 39 & $13.00 \%$ \\
\hline Feldspar & 3.00 & 23 & $7.67 \%$ \\
\hline Lithics & 3.54 & 183 & $61.00 \%$ \\
\hline Other & 2.67 & 55 & $18.33 \%$ \\
\hline Total & 3.28 & 300 & \\
\hline
\end{tabular}

\begin{tabular}{|l|r|r|r|}
\hline 7.7 & Roundness & $\begin{array}{l}\text { Grain } \\
\text { counts }\end{array}$ & \multicolumn{1}{l|}{$\%$} \\
\hline Quartz & 3.15 & 26 & $8.64 \%$ \\
\hline Feldspar & 3.00 & 30 & $9.97 \%$ \\
\hline Lithics & 3.15 & 227 & $75.42 \%$ \\
\hline Other & 2.78 & 18 & $5.98 \%$ \\
\hline Total & 3.11 & 301 & \\
\hline
\end{tabular}




\begin{tabular}{|c|c|c|c|c|c|c|c|c|c|c|c|}
\hline & & TS1 & TS2 & TS4 & TS6 & TS8 & TS10 & TS11 & TS12 & TS13 & TS14 \\
\hline \multirow{5}{*}{ Roundness } & Quartz & 3.32 & 3.13 & 3.10 & 2.90 & 3.28 & 3.08 & 2.82 & 3.28 & 3.16 & 3.08 \\
\hline & Feldspar & 3 & 2.95 & 3.09 & 2.69 & 2.84 & 2.85 & 2.87 & 3.19 & 3.30 & 2.71 \\
\hline & Lithics & 3.91 & 3.62 & 3.71 & 3.64 & 3.77 & 3.63 & 3.74 & 3.65 & 3.78 & 3.68 \\
\hline & Other & 2.93 & 2.65 & 3.21 & 2.76 & 2.78 & 3.25 & 2.93 & 3.06 & 2.75 & 3.10 \\
\hline & Total & 3.65 & 3.35 & 3.43 & 3.32 & 3.45 & 3.37 & 3.44 & 3.47 & 3.55 & 3.45 \\
\hline \multirow{4}{*}{$\begin{array}{l}\text { Mineralogical } \\
\text { composition }\end{array}$} & Quartz & $32.00 \%$ & $29.67 \%$ & $31.46 \%$ & $24.33 \%$ & $31.33 \%$ & $27.67 \%$ & $20.00 \%$ & $28.67 \%$ & $22.67 \%$ & $24.33 \%$ \\
\hline & Feldspar & $2.67 \%$ & $7.00 \%$ & $7.62 \%$ & $5.33 \%$ & $8.33 \%$ & $11.33 \%$ & $5.00 \%$ & $7.00 \%$ & $11.00 \%$ & $4.67 \%$ \\
\hline & Lithics & $60.33 \%$ & $54.67 \%$ & $52.98 \%$ & $60.67 \%$ & $51.33 \%$ & $55.67 \%$ & $65.67 \%$ & $58.33 \%$ & $62.33 \%$ & $64.33 \%$ \\
\hline & Other & $5.00 \%$ & $8.67 \%$ & $7.95 \%$ & $9.67 \%$ & $9.00 \%$ & $5.33 \%$ & $9.33 \%$ & $6.00 \%$ & $4.00 \%$ & $6.67 \%$ \\
\hline
\end{tabular}




\section{Appendix 3: Age Control}

The details on the dates produced through radiocarbon (c14) dating, and optically stimulated luminescence (OSL) are presented in below.

\section{C14}

\begin{tabular}{|l|c|l|l|l|l|l|l|}
\hline & $\begin{array}{r}\text { Dep } \\
\text { th } \\
\text { Core }\end{array}$ & $\begin{array}{r}\text { Age (years } \\
\text { calBP) (20') }\end{array}$ & $\begin{array}{r}\text { Conventional } \\
\text { radiocarbon }\end{array}$ & $\begin{array}{r}\text { Lab } \\
\text { facility }\end{array}$ & $\begin{array}{r}\text { Lab } \\
\text { code }\end{array}$ & $\begin{array}{r}\text { Material } \\
\text { dated }\end{array}$ & $\begin{array}{r}\text { Sedit } \\
\text { sampled } \\
\text { from }\end{array}$ \\
\hline WS1 & 1.7 & $2330 \pm 30$ & $2337 \pm 29$ & Waikato & Wk4 & Wood & Organic \\
& & & C14 & 1780 & pieces & rich unit \\
\hline WS3 & 27.8 & $8507 \pm 208$ & $7717 \pm 99$ & Waikato & Wk4 & Piece of & Sandstone \\
\hline AB4 & 7.4 & 35,849 & $33482 \pm 701$ & GNS & NZA & Piece of & Organic \\
& & \pm 1692 & & Rafter & 6265 & wood & rich unit \\
& & & & & 1 & & \\
\hline
\end{tabular}

OSL

\begin{tabular}{|c|c|c|c|c|c|c|}
\hline Core & Depth (m) & $\begin{array}{l}\text { Age (years } \\
\text { calBP) (20') }\end{array}$ & $\begin{array}{r}\text { Lab } \\
\text { facility }\end{array}$ & Lab code & $\begin{array}{r}\text { Material } \\
\text { dated }\end{array}$ & $\begin{array}{r}\text { Sed. unit } \\
\text { sampled } \\
\text { from }\end{array}$ \\
\hline \multirow[t]{4}{*}{ WS3 } & 17.69 & $5270 \pm 360$ & $\begin{array}{l}\text { VUW } \\
\text { OSL }\end{array}$ & WSLL1198 & Sand & Sandstone \\
\hline & 18.15 & $5430 \pm 370$ & $\begin{array}{l}\text { VUW } \\
\text { OSL }\end{array}$ & WSLL1199 & Sand & Sandstone \\
\hline & 27.5 & $6030 \pm 410$ & $\begin{array}{l}\text { VUW } \\
\text { OSL }\end{array}$ & WSLL1200 & Sand & Sandstone \\
\hline & 27.94 & $6060 \pm 420$ & $\begin{array}{l}\text { VUW } \\
\text { OSL }\end{array}$ & WSLL1201 & Sand & Sandstone \\
\hline
\end{tabular}




\section{Appendix 4: Cores and Outcrops}

Details of the cores and outcrops used in this study are presented below.

\begin{tabular}{|c|c|c|c|c|}
\hline Name & Coordinates & Length/Height & $\begin{array}{l}\text { Elevation of top of } \\
\text { core/base of section }\end{array}$ & Age Control \\
\hline SFT & $\begin{array}{l}-40.999078, \\
174.940211\end{array}$ & $4.75 \mathrm{~m}$ high & $\begin{array}{l}2.4 \mathrm{~m} \text { above max low } \\
\text { tide }\end{array}$ & $\mathrm{Nil}$ \\
\hline NFT & $\begin{array}{l}-40.996268 \\
174.942740\end{array}$ & 9.7m high & $\begin{array}{l}2.8 \mathrm{~m} \text { above max low } \\
\text { tide }\end{array}$ & $\mathrm{Nil}$ \\
\hline WS1 & $\begin{array}{l}-40.972719 \\
174.960490\end{array}$ & $2.2 \mathrm{~m}$ long & $2.3 \mathrm{~m}$ asl & C14@1.7m \\
\hline WS3 & $\begin{array}{l}-40.972457 \\
174.960568\end{array}$ & $29 \mathrm{~m}$ long & $2 \mathrm{~m}$ asl & $\begin{array}{c}\text { C14 @27.8m } \\
\text { OSL @17.69m } \\
@ 18.15 \mathrm{~m} \\
@ 27.5 \mathrm{~m} \\
@ 27.94 \mathrm{~m}\end{array}$ \\
\hline $\begin{array}{l}\text { Pickle } \\
\text { Pot }\end{array}$ & $\begin{array}{l}-40.968884 \\
174.962007\end{array}$ & $2.85 \mathrm{~m}$ high & $\begin{array}{l}2.5 \mathrm{~m} \text { above max low } \\
\text { tide }\end{array}$ & $\mathrm{Nil}$ \\
\hline $\mathrm{AB1}$ & $\begin{array}{l}-40.902648 \\
174.990309\end{array}$ & 11.5m long & $6.1 \mathrm{~m}$ asl & $\mathrm{Nil}$ \\
\hline$A B 2$ & $\begin{array}{l}-40.902985 \\
174.990830\end{array}$ & $10 \mathrm{~m}$ long & $6.1 \mathrm{~m}$ asl & $\mathrm{Nil}$ \\
\hline$A B 3$ & $\begin{array}{l}-40.905831 \\
174.990170\end{array}$ & 19.5m long & $5.9 \mathrm{~m}$ asl & $\mathrm{Nil}$ \\
\hline $\mathrm{AB} 4$ & $\begin{array}{l}-40.902819 \\
174.990449\end{array}$ & 10.5m long & $6.1 \mathrm{~m}$ asl & C14@7.4m \\
\hline
\end{tabular}

